\title{
Ulif norden
}

\section{Kvalitetsmåling i psykiatrien i de nordiske lande}

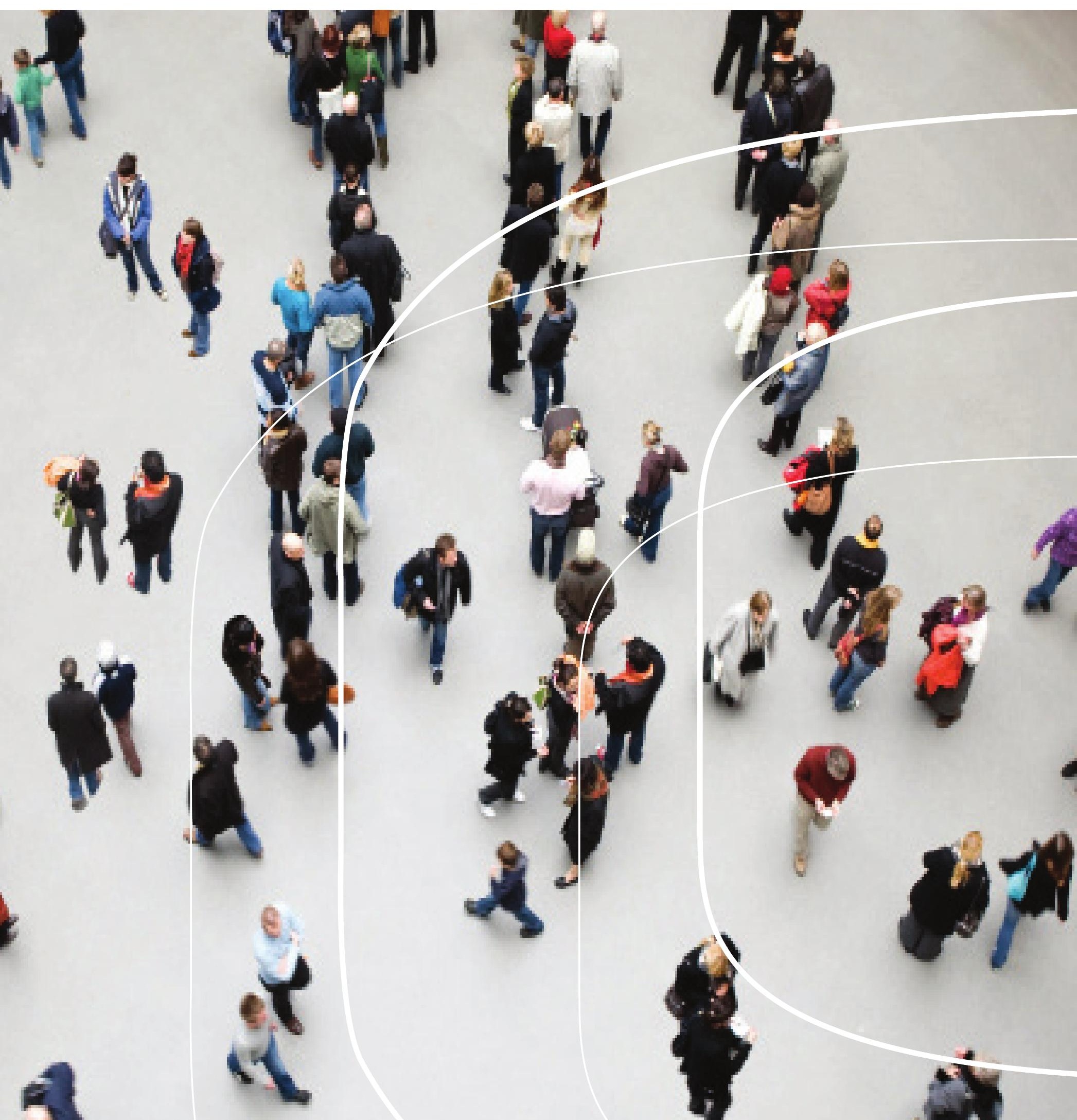


enorden 



\section{Kvalitetsmåling i psykiatrien i de nordiske lande}

Projektgruppen under Nordisk Ministerråd 
Kvalitetsmåling i psykiatrien i de nordiske lande

Projektgruppen under Nordisk Ministerråd

TemaNord 2011:542

ISBN 978-92-893-2243-0

(C) Nordisk Ministerråd, København 2011

Tryk: Kailow Express ApS

Omslagsfoto: Image Select

Oplag: 130

Printed in Denmark

Denne rapport er udgivet med finansiel støtte fra Nordisk Ministerråd. Indholdet i rapporten afspejler dog ikke nødvendigvis Nordisk Ministerråds synspunkter, meninger, holdninger eller anbefalinger.

www.norden.org/publikationer

www.norden.org

\section{Det nordiske samarbejde}

Det nordiske samarbejde er en af verdens mest omfattende regionale samarbejdsformer. Samarbejdet omfatter Danmark, Finland, Island, Norge og Sverige samt Færøerne, Grønland og Åland.

Det nordiske samarbejde er både politisk, økonomisk og kulturelt forankret, og er en vigtig medspiller i det europæiske og internationale samarbejde. Det nordiske fællesskab arbejder for et stærkt Norden i et stærkt Europa.

Det nordiske samarbejde ønsker at styrke nordiske og regionale interesser og værdier i en global omverden. Fælles værdier landene imellem er med til at styrke Nordens position som en af verdens mest innovative og konkurrencedygtige regioner.

\section{Nordisk Ministerråd}

Ved Stranden 18

1061 København K

Telefon (+45) 33960200

www.norden.org 


\section{Indhold}

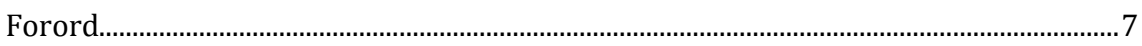

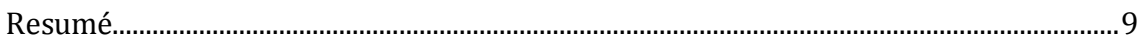

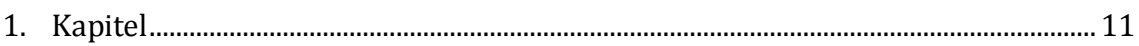

1.1 Kvalitetsindikatorer indenfor psykiatrien .................................................. 11

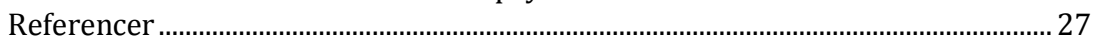

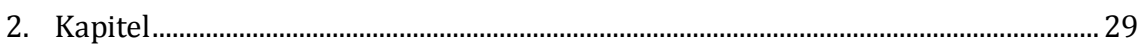

2.1 Valg af prioriterede og potentielle kvalitetsindikatorer ............................... 29

$2.2 \quad$ Skizofreni - voksne............................................................................................ 31

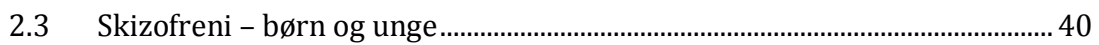

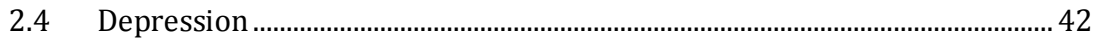

2.5 Bipolar lidelse .................................................................................................... 47

2.6 ADHD (Attention Deficit/Hyperactivity Disorder).........................................5 54

2.7 Generiske kvalitetsindikatorer ....................................................................... 58

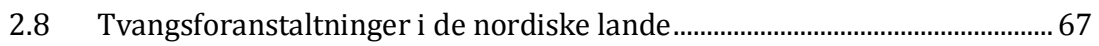

$2.9 \quad$ ECT-behandling (Electro Convulsive Therapy) ………................................... 75

2.10 Nationale kliniske retningslinjer og nationale registre i de nordiske lande .................................................................................................. 81

2.11 Hovedresultater af patient- og pårørendeenqueter......................................... 84

2.12 Kvalitetsindikatorer under udvikling i de nordiske lande............................120

Referencer ...............................................................................................................128

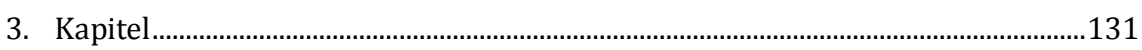

3.1 Diskussion ..................................................................................................131

Referencer ............................................................................................................133

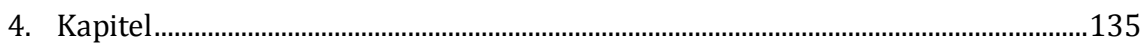

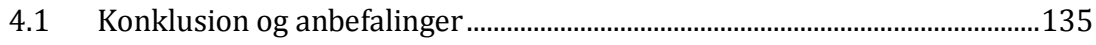

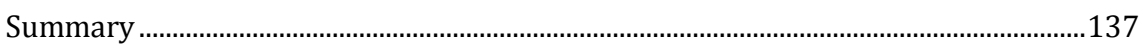

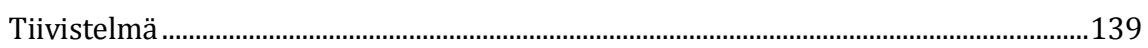

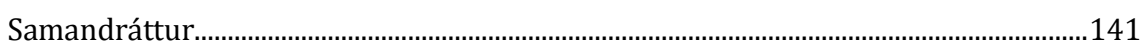

Inussiarnersumik Inuulluaqqusillunga .................................................................... 143

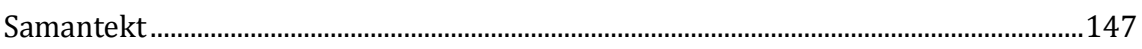

Bilag 1: Repræsentanter i styregruppen for nordisk kvalitetsmåling ..........................149

Bilag 2: Oversigt over nationale kvalitetsindikatorer indenfor psykiatri til offentliggørelse i de nordiske lande.....................................................................151

Danmark.................................................................................................................151

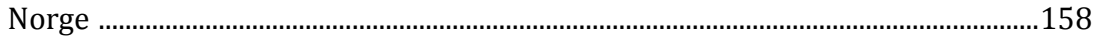

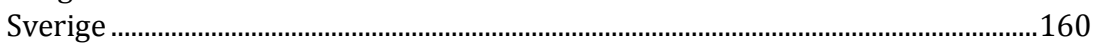

Bilag 3: Oversigt over nationale kliniske retningslinjer med links ...............................163

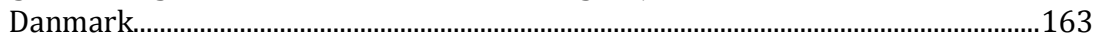

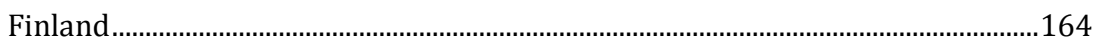

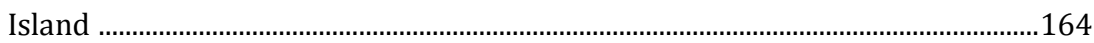

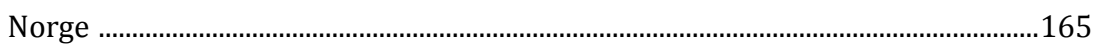

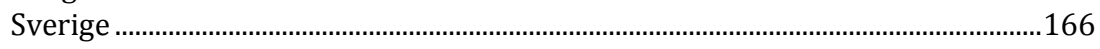

Bilag 4. Samlet liste i denne rapport med indikatorer indenfor psykiatrien...............167

Bilag 5. English definition - indicators......................................................................179 



\section{Forord}

Kvalitetsudvikling og patientsikkerhed indenfor psykiatrien er højt prioriteret i de nordiske lande, og der er iværksat vigtige initiativer i de respektive lande. Den foreliggende rapport skal ses i sammenhæng med dette arbejde.

Formålet har været at tilvejebringe et grundlag for de nordiske borgere, politikere, sundhedspersonale og sundhedsmyndigheder til at vurdere og sammenligne kvaliteten af sundhedsvæsenets ydelser indenfor psykiatrien og således sikre gennemsigtighed og gennemskuelighed. Formålet har endvidere været at tilvejebringe dokumentation, der kan tjene til inspiration mellem de nordiske lande med henblik på at forbedre kvaliteten for dem, det hele drejer sig om, brugerne af sundhedsvæsenet - patienterne og de pårørende.

Rapporten skal således bidrage til belysning af kvaliteten af sundhedsvæsenets ydelser indenfor psykiatrien og muliggøre sammenligninger og benchmarking mellem de nordiske lande på tværs af landegrænserne.

Resultaterne viser, at kvaliteten indenfor psykiatrien kan sammenlignes på en række områder mellem de nordiske lande, men rapporten viser også, at det er en opgave for de nordiske sundhedsvæsner at sikre, at resultaterne er retvisende og sammenlignelige.

Den samlede rapport illustrerer, at de nordiske lande har enestående muligheder for kvalitetsmåling, hvilket bl.a. skyldes velfungerende kvalitetsregistre.

På internationalt niveau er de nordiske lande således blandt de lande, der er nået længst med kvalitetsudvikling og patientsikkerhed på nationalt niveau indenfor psykiatrien.

Denne rapport fra Nordisk Ministerråd kan anvendes i de respektive nordiske lande som grundlag for at forbedre kvaliteten i indsatsen for de psykiatriske patienter, ligesom den kan bidrage til inspiration for kvalitetsmåling på internationalt niveau, herunder i OECD, WHO og EU.

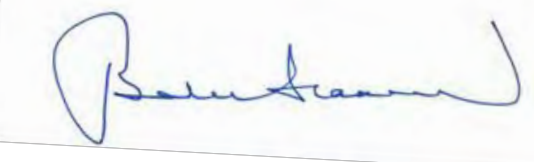

Bertel Haarder

Indenrigs- og sundhedsminister 



\section{Resumé}

Nordisk Ministerråd iværksatte i 2007 projektet: Nordisk kvalitetsmåling i sundhedsvæsenet, som omfattede fire delprojekter, der havde til formål i projektperioden 2007-2010 at udvikle og beskrive fællesnordiske:

1. Generiske og sygdomsspecifikke kvalitetsindikatorer

2. Kvalitetsindikatorer for mund- og tandsundhed

3. Patientsikkerhedsindikatorer

4. Kvalitetsindikatorer for patientoplevet kvalitet

Resultaterne fra projektet udkom i 2010 i en fælles rapport med resultater fra de fire projekter under titlen: Nordisk kvalitetsmåling i sundhedsvæsenet TemaNord 2010:572 (1).

I projektperioden blev det besluttet, at fællesnordiske kvalitetsindikatorer for psykiatrien skulle beskrives i en særskilt rapport i perioden fra september 2010 til juli 2011. Denne rapport er resultatet heraf.

Det overordnede formål er at give de nordiske borgere, politikere, sundhedspersonale og sundhedsmyndigheder mulighed for at vurdere og sammenligne sundhedsvæsenets ydelser på tværs af de nordiske landegrænser, samt at identificere områder, hvor de nordiske lande kan lære af hinanden med henblik på at forbedre kvaliteten af sundhedsvæsenets ydelser for dem, det hele drejer sig om, nemlig patienterne.

Projektgruppen skulle udarbejde forslag til indikatorer, som kunne danne grundlag for registrering og monitorering af kvaliteten af sundhedsvæsenets ydelser i de nordiske lande indenfor psykiatrien.

Projektgruppen besluttede at inddrage alle kvalitetsindikatorer, der anvendes til belysning af kvaliteten af sundhedsvæsenets ydelser i de nordiske sundhedsvæsener i relation til hospitalsbehandling, samt potentielle indikatorer, som forventes implementeret i de nordiske lande i den nærmeste fremtid indenfor følgende områder:

- Generiske psykiatriske indikatorer

- Tvangsforanstaltninger

- ECT (Electro Convulsive Therapy)

- Skizofreni, voksne, samt børn og unge

- Depression (moderat og svær depression i hospitalsregi)

- Bipolar Lidelse

- ADHD (Attention Deficit/Hyperactivity Disorder)

- Patient- og pårørendeoplevet kvalitet 
I rapporten præsenteres således alle kvalitetsindikatorer, der anvendes $\mathrm{i}$ de respektive nordiske lande indenfor disse områder i psykiatrien i relation til behandling af patienter i den sekundære sundhedssektor, dvs hospitalsbehandling samt ambulant behandling i relation hertil. I rapporten præsenteres desuden konkrete eksempler på kvalitetsmålinger på grundlag af indikatorer i de respektive lande for at illustrere indikatormålingers anvendelse for kvalitetsudvikling indenfor psykiatrien i de nordiske lande.

Rapporten viser, at det på nogle områder er muligt at tilvejebringe data, som muliggør sammenligning på tværs af de nordiske lande, mens der på andre områder kun i beskedent omfang findes tilgængelige data. Dette indebærer, at der fortsat på en række områder er behov for at udvikle fællesnordiske indikatorer. Rapporten illustrerer ligeledes, at der er behov for en betydelig indsats med henblik på at sikre datakvaliteten. Dette indebærer, at en række af resultaterne næppe er retvisende, dels fordi data opgøres forskelligt i de nordiske lande, og dels fordi data på visse områder kun findes i begrænset omfang.

Rapporten dokumenterer, at der i de nordiske lande er et stort potentiale for måling og monitorering af kvaliteten af sundhedsvæsenets ydelser indenfor psykiatrien. Internationalt er dette område svagt belyst. I international sammenhæng er de nordiske lande således blandt de lande, der er nået længst med national kvalitetsmåling. Dette skyldes, at kvalitetsudvikling i de nordiske lande er højt prioriteret, samt at de nordiske lande har unikke muligheder for kvalitetsmåling indenfor psykiatrien, dels fordi der er etableret velfungerende sundhedsregistre, og dels fordi det er muligt at indsamle data relateret til den enkelte patient.

Der er således næppe tvivl om, at de nordiske lande kan bidrage i betydeligt omfang til inspiration og samarbejde om kvalitetsmåling på grundlag af kvalitetsindikatorer indenfor psykiatrien på internationalt niveau. 


\section{Kapitel}

\subsection{Kvalitetsindikatorer indenfor psykiatrien}

Nordisk Ministerråd iværksatte i 2007 projektet: Nordisk kvalitetsmåling i sundhedsvæsenet, som omfattede fire delprojekter, der havde til formål i projektperioden 2007-2010 at udvikle og beskrive fællesnordiske:

1. Generiske og sygdomsspecifikke kvalitetsindikatorer

2. Kvalitetsindikatorer for mund- og tandsundhed

3. Patientsikkerhedsindikatorer

4. Kvalitetsindikatorer for patientoplevet kvalitet

I projektperioden blev der udviklet generiske og sygdomsspecifikke kvalitetsindikatorer for følgende områder:

- Kræftsygdomme

- Hjerte/karsygdomme

- Diabetes og astma

- Graviditet og fødsel

- Børn og unge

- Sundhedsfremme og forebyggelse

- Generelle indikatorer

I 2010 udkom en fælles rapport med resultater fra de fire projekter under titlen: Nordisk kvalitetsmåling i sundhedsvæsenet TemaNord 2010:572 (1).

I projektperioden blev det besluttet, at fællesnordiske kvalitetsindikatorer for psykiatrien skulle beskrives i en særskilt rapport. Derfor ansøgte man i projektet om yderligere økonomiske midler i Nordisk Ministerråd, som bevilgede, at projektperioden blev udvidet til 30. juni 2011 med det formål at videreudvikle fællesnordiske kvalitetsindikatorer indenfor psykiatrien. Denne rapport omhandler således fælles nordiske kvalitetsindikatorer indenfor psykiatrien.

\subsubsection{Kommissorium for projektgruppens virksomhed}

Projektgruppen skulle udarbejde forslag til indikatorer indenfor psykiatrien, som kunne danne grundlag for registrering og overvågning af kvaliteten af sundhedsvæsenets ydelser i de nordiske lande.

Til belysning af kvaliteten af sundhedsvæsenets ydelser kunne indgå prioriteringskriterier som: Volumen, alvorlighed, variation og økonomi. 
Valg af indikatorer skulle afspejle den sundhedsfaglige og den organisatoriske, samt den patientoplevede kvalitet i relation til struktur, proces og resultat.

Projektgruppen blev videreført fra september 2010 med en sammensætning således, at hvert land var sikret orientering fra OECD-møder, samt havde let adgang til dialog med OECD. Herudover kunne der indkaldes ad hoc eksperter ved behov til gruppens møder.

\subsubsection{Sammensætning og repræsentation $i$ projektgruppen}

For at kunne dække områderne i kommissoriet tilstrækkeligt bredt, skulle gruppen bestå af 1-2 personer fra hvert land. Repræsentanterne skulle have godt kendskab til de i kommissoriet nævnte fokusområder.

Projektlederen skulle besidde kompetence inden for kvalitetsmålingsområdet på højt internationalt niveau, have national og international erfaring med udvikling af kvalitetsindikatorer, have erfaring med kvalitetsmåling, implementering af indikatorer i sundhedsvæsenet, formidling af indikatorer, samt have et bredt netværk i relevante internationale miljøer, herunder i EU-, WHO- og OECD-regi.

Projektgruppen blev sammensat af 1-3 repræsentanter fra Danmark, Finland, Færøerne, Grønland, Island, Norge og Sverige. Hvert land forestod selv udpegningen af repræsentanterne, som skulle dække de faglige områder, som arbejdsgruppen skulle beskæftige sig med.

Formandskabet og sekretariatsfunktionen er i projektperioden blevet varetaget af Danmark. Projektgruppen refererede til den allerede etablerede styregruppe. Deltagere i styregruppen kan ses i bilag 1.

Nedenfor ses en oversigt over repræsentanterne i den nordiske projektgruppe vedr. psykiatri, samt sekretariat:

\section{Danmark}

- Jan Mainz, professor, ledende overlæge, Ph.D, Sundhedsstyrelsen, formand og OECD-repræsentant

- Paul Bartels, cheflæge, leder af Det Nationale Indikatorprojekt, NIP, udpeget af Dansk Medicinsk Selskab

\section{Sekretariat:}

- Jytte Burgaard, sygeplejerske, MPA, konsulent, Sundhedsstyrelsen

- Carsten Rødseth Barsøe, projektmedarbejder, Sundhedsstyrelsen

Observatør:

- Birgit Villadsen, ledende oversygeplejerske, Bispebjerg Hospital

\section{Finland}

- Päivi Hämäläinen, udviklingschef, Stakes/THL Institutet för hälsa och välfärd, OECD-repræsentant 
- Sari Palojoki, utvecklingschef, Stakes/THL Institutet för hälsa och välfärd

- Mika Gissler, forskningsprofessor Stakes/THL Institutet för hälsa och välfärd

\section{Færøerne}

- Høgni Debes Joensen, landslæge, Sundhedsministeriet

\section{Grønland}

- Birgit Niclasen, lægefaglig konsulent, Departementet for Sundhed

\section{Island}

- Anna Björg Aradóttir, chefsygeplejerske, Sundhedsstyrelsen

- Guðrún Kr. Guðfinnsdóttir, Project Manager, Division of Health Statistics, Directorate of Health

\section{Norge}

- Målfrid Monge, seniorrådgiver, avdeling statistikk, Helsedirektoratet

- Jon Helgland, seniorrådgiver, Nasjonalt kunnskapssenter for helsetjenesten

- Rut Prietz, seniorrådgiver, avdeling psykisk helsevern og rus, Helsedirektoratet

- Linda Haugan, seniorrådgiver, avdeling statistikk, Helsedirektoratet

\section{Sverige}

- Max Köster, statistiker, Socialstyrelsen, OECD-repræsentant

- Marie Lawrence, enhetschef, Socialstyrelsen, OECD-repræsentant

- Birgitta Lindelius, utredare, Socialstyrelsen

- Tord Forsner, utredare, Socialstyrelsen

- Emma Björkenstam, utredare, statistiker, Statistik och Utvärdering, Socialstyrelsen

\subsubsection{Introduktion}

Projektgruppen skulle udarbejde forslag til indikatorer, som kunne danne grundlag for registrering og monitorering af kvaliteten af sundhedsvæsenets ydelser i de nordiske lande indenfor psykiatrien. Samtlige prioriterede og potentielle indikatorer i tidligere publikationer $(1,2)$ samt relevante OECD-indikatorer (3), skulle indgå i arbejdet med henblik på stillingtagen til, om de efterfølgende skulle indgå i det endelige indikatorsæt.

Projektgruppen har afholdt 4 møder af hver 2 dages varighed i den forlængede projektperiode. I arbejdet indgik indikatormateriale fra både de nordiske lande og fra OECD, samt fra internationale indikatorprojekter og databaser.

På grundlag af dette materiale foretog projektgruppen prioritering og valg af dels overordnede temaer og dels sundhedsfaglige indikatorer i relation til struktur, proces og resultat. 
Det har i projektgruppens arbejde været et grundlæggende princip, at de respektive repræsentanter for de nordiske lande skulle bidrage til projektgruppens prioriteringer på grundlag af fastlagt mandat i de respektive lande. Projektgruppen besluttede at identificere alle kvalitetsindikatorer, der anvendes til belysning af kvaliteten af sundhedsvæsenets ydelser i de nordiske sundhedsvæsener, samt potentielle indikatorer, som forventes implementeret i de nordiske lande i den nærmeste fremtid.

I rapporten præsenteres således alle indikatorer, der anvendes som kvalitetsindikatorer i de respektive lande. I bilag 2 ses oversigter over kvalitetsindikatorer pr. land, og i bilag 4 ses en oversigt over den samlede liste af indikatorer, som præsenteres i denne rapport.

I rapporten præsenteres desuden konkrete eksempler på kvalitetsmålinger på grundlag af indikatorer i de respektive lande for at illustrere indikatormålingers anvendelse som led i kvalitetsudvikling.

Til alle møderne er faglige eksperter inviteret til at bidrage med viden og rådgivning om de indikatorområder projektgruppen havde under bearbejdelse.

\subsubsection{Valg af fokusområder indenfor psykiatri}

Projektgruppen besluttede på det indledende møde, hvilke overordnede fokusområder, der skulle indgå i projektgruppens arbejde. Med mandat fra de enkelte lande besluttedes det, at der skulle videreudvikles kvalitetsindikatorer indenfor følgende områder:

- Generiske psykiatriske indikatorer

- Tvangsforanstaltninger

- ECT (Electro Convulsive Therapy)

- Skizofreni, voksne, samt børn og unge

- Depression (moderat og svær depression i hospitalsregi)

- Bipolar Lidelse

- ADHD (Attention Deficit/Hyperactivity Disorder)

- Patient- og pårørendeoplevet kvalitet

Projektgruppen besluttede som anført, at alle kvalitetsindikatorer, der er implementeret i de nordiske lande, skulle indgå i det fællesnordiske indikatorsæt, ligesom der i den afsluttende rapport skulle indgå konkrete data fra det pågældende land, samt fra de øvrige lande, såfremt disse havde tilgængelige data. Ligeledes blev det besluttet, at kvalitetsindikatorer, som de nordiske lande havde intensioner om at implementere, skulle anføres som potentielle indikatorer. 


\subsubsection{Forståelsesramme}

I Nordisk Ministerråds projektgruppe er OECDs forståelsesramme for monitorering af kvaliteten af sundhedsvæsenets ydelser adapteret, hvilket er illustreret i figur 1.1 (4).

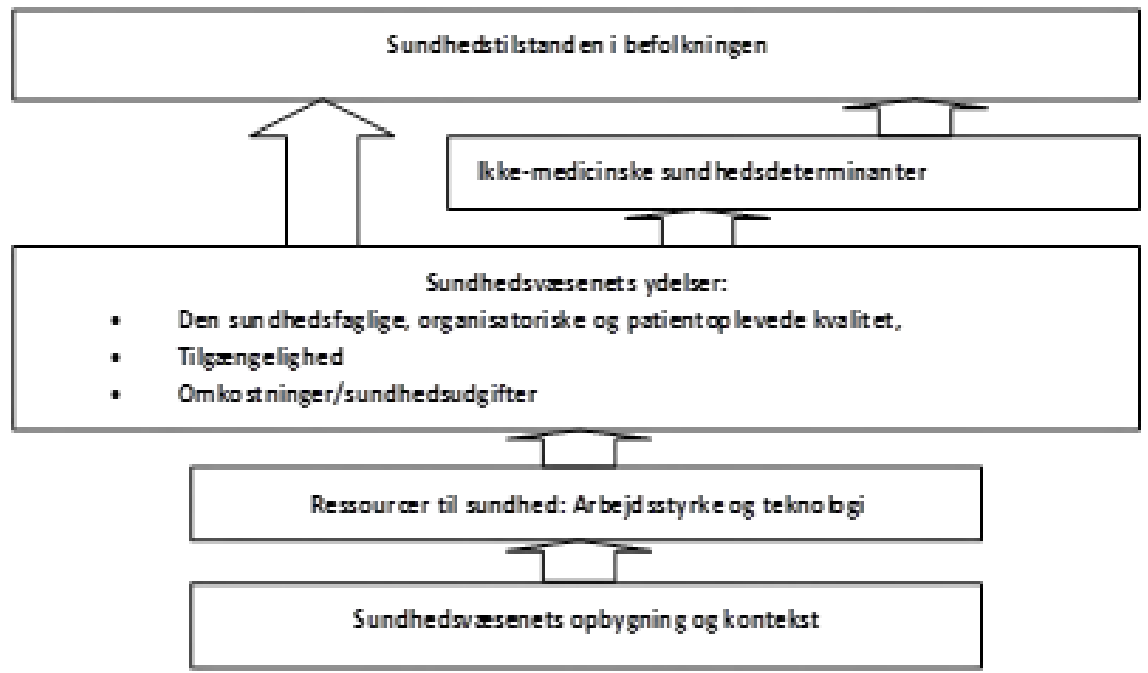

Figur 1.1: Forståelsesramme for monitorering af sundhedsvæsenets ydelser på grundlag af kvalitetsindikatorer

Kilde. Adaptation of the OECD (2006), Conceptual Framework for the OECD Health Care Quality Indicators Project, OECD Health Working Paper, No. 23, OECD Publishing, Paris. Health at a Glance 2009: OECD Indicators C OECD 2009

Det fremgår af forståelsesrammen, at sundhedsvæsenets overordnede mål er at forbedre befolkningens sundhedstilstand, som afhænger af en række ikke-medicinske determinanter, herunder det sociale, økonomiske og fysiske miljø, som befolkningen lever i, samt befolkningens livsstil og sundhedsadfærd.

Sundhedsvæsenet bidrager ligeledes til befolkningens sundhedstilstand. Dette bidrag afhænger blandt andet af kvaliteten af sundhedsvæsenets ydelser, samt af tilgængeligheden til ydelserne.

Kvaliteten af sundhedsvæsenets ydelser omfatter den sundhedsfaglige kvalitet i relation til forebyggelse, diagnostik, behandling, pleje og rehabilitering samt den organisatoriske kvalitet, dvs. kontinuitet og koordination af sundhedsvæsenets ydelser. Endelig omfatter kvaliteten af sundhedsvæsenets ydelser også den patientoplevede kvalitet, dvs. brugerens oplevelse af udførelsen af sundhedsvæsenets ydelser, samt resultatet heraf $(5,6,7)$.

Endvidere afhænger sundhedsvæsenets præstationer af de tilgængelige ressourcer i form af kvalificeret sundhedspersonale samt tilgængelighed til medicinsk teknologi og udstyr.

Endelig spiller en række faktorer en rolle for sundhedsvæsenets præstationer, herunder den demografiske, økonomiske og sociale kontekst samt sundhedsvæsenets opbygning. 
Som det fremgår af forståelsesrammen (figur 1.1), er der en kompleks række af faktorer, der skal inddrages, når man skal fortolke kvaliteten af sundhedsvæsenets ydelser på grundlag af kvalitetsindikatorer. Fortolkningen af kvalitetsdata bliver endnu mere kompleks, såfremt dette sker på internationalt niveau, hvor en lang række faktorer i relation til forståelsesrammen kan variere. Dette indebærer, at konkrete indikatorresultater på internationalt niveau skal fortolkes med stor omhyggelighed og forsigtighed.

Nordisk Ministerråds samlede projekt om kvalitetsmåling fokuserer især på monitorering af kvaliteten af sundhedsvæsenets ydelser, samt helbredseffekten heraf for befolkningen.

\subsubsection{Model for præsentation af kvalitetsindikatorer}

Med henblik på at belyse kvaliteten af sundhedsvæsenets ydelser i relation til de valgte områder på en nuanceret måde, udarbejdede projektgruppen en generisk model allerede i det oprindelige projekt fra 20072010 (1). Denne model anvendes ligeledes til præsentation af indikatorerne indenfor psykiatrien. Modellens opbygning fremgår af figur 1.2 nedenfor.

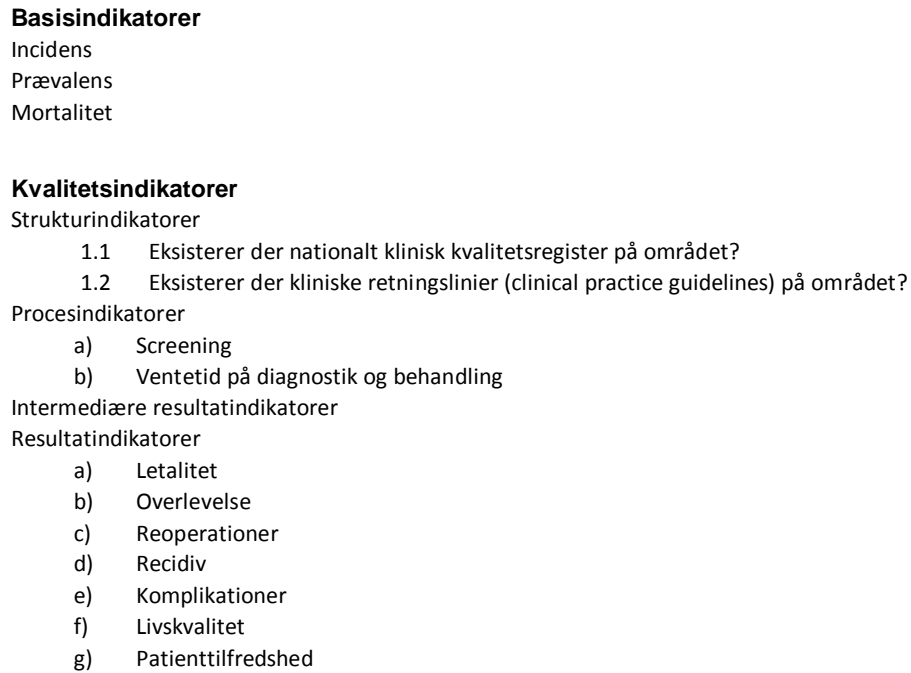

Figur 1.2: Generisk model for kvalitetsindikatorer

Som det fremgår, indgår såvel basisindikatorer som kvalitetsindikatorer i modellen.

Basisindikatorerne belyser hyppigheden af en given sygdom (prævalensen), samt hastigheden for sygdommens udvikling (incidensen). Hertil kommer mortaliteten, dvs. dødeligheden indenfor en sygdomsgruppe.

Kvalitetsindikatorerne præsenteres i relation til struktur, proces og resultat med henblik på at belyse, hvilket grundlag der er for behandling af den pågældende sygdom (strukturen), hvilke aktiviteter (diagnostik, 
behandling, pleje, rehabilitering og forbyggelse) der er iværksat i relation til patientforløbene, samt hvilke resultater der opnås for patienterne, dvs. patienternes helbredsgevinst.

Den generiske model som grundlag for præsentation af kvalitetsindikatorer er udviklet i erkendelse af, at en enkelt indikator sjældent alene kan beskrive kvaliteten af sundhedsvæsenets ydelser for et sygdomsområde.

Den grundlæggende ide med den generiske model er at beskrive en pakke af indikatorer, der tilsammen kan beskrive kvaliteten af sundhedsvæsenets ydelser i sammenhæng med sygdommens omfang og udvikling.

Da der er tale om en generisk model, betyder dette, at ikke alle modellens elementer vil være relevante for alle sygdomme eller alle kliniske tilstande indenfor psykiatri.

Som det fremgår af den generiske model, indgår livskvalitet i modellen. Projektgruppen har hermed ønsket at signalere, at der principielt bør inkluderes indikatorer til belysning heraf.

Der findes imidlertid ikke aktuelt data på nationalt niveau til belysning af livskvalitet.

Som nævnt har den generiske model været udgangspunktet for udvikling af generiske og sygdomsspecifikke indikatorer.

Projektgruppen har valgt såkaldt prioriterede kvalitetsindikatorer, hvor de fleste nordiske lande umiddelbart kan tilvejebringe valide data i relation til den generiske model. Som anført har projektgruppen herudover identificeret såkaldte potentielle kvalitetsindikatorer, som forventes implementeret i de respektive nordiske lande. Se afsnit 2.12.

\subsubsection{Generelt om kvalitetsindikatorer}

En kvalitetsindikator er en målbar variabel, som kan anvendes til at overvåge og evaluere kvaliteten af sundhedsvæsenets ydelser $(7,8)$.

Kvalitetsindikatorer kan anvendes til at monitorere sundhedsvæsenets struktur og organisation, strategisk vigtige aspekter af patientforløbet, samt resultatet af sundhedsvæsenets ydelser for patienten dvs. helbredsgevinsten. Indikatorer kan sjældent stå alene, men kan anvendes som led i en samlet faglig analyse, vurdering og fortolkning.

Man kan skelne mellem strukturindikatorer, procesindikatorer og resultatindikatorer (9):

- Strukturindikatorer beskriver sundhedsvæsenets rammer og ressourcer, herunder sundhedsprofessionernes kompetencer og tilgængeligheden til udstyr, teknologi og faciliteter. Indikatorerne beskriver med andre ord forudsætningerne og rammerne for forebyggelse, diagnostik, behandling, pleje og rehabilitering

- Procesindikatorer angiver konkrete aktiviteter i patientforløbet og giver dermed et billede af i hvilket omfang, sundhedspersonalet har udført bestemte procedurer, eksempelvis forebyggelse, diagnostik, behandling, pleje og rehabilitering eller kommunikation, i 
patientforløbet. Procesindikatorer udvikles på grundlag af referenceprogrammer eller kliniske retningslinjer, såfremt de findes. Procesindikatorerne udtrykker, om patienterne har modtaget de ydelser, som de bør ifølge referenceprogrammer og kliniske retningslinjer

- Resultatindikatorer belyser patientens helbredsgevinst i form af overlevelse, symptomatologiske og laboratoriemæssige karakteristika, patientens fysiske formåen eller psykiske reaktioner på sygdomme og tilfredsheden med behandlingen (10)

\subsubsection{Indikatordefinition}

Det skal for hver enkelt indikator sikres, at der er enighed om definition af termer herunder definition af tæller og nævner i opgørelsen af indikatorresultater. I dette projekt er der ikke for alle indikatorer udarbejdet specifikke fælles indikatoralgoritmer, og derfor bør der være fokus på mulighed for, at forskelle i resultater kan skyldes forskelle i definition af tæller/nævner.

Data for incidens eller dødelighed bliver ofte vist som rater. For en given sygdom og population beregnes den rå rate (crude rate) ved at dividere antal nye sygdomstilfælde eller dødsfald ved sygdommen i en given periode med det tilsvarende antal personer fra populationen under risiko. Når der er tale om psykiatri, angives resultatet oftest som en årlig rate per 100.000 personer.

En standardiseret rate (ASR) er et samlet mål for den rate, som en befolkningsgruppe (population) ville have, hvis den havde en standard aldersstruktur. Standardisering er nødvendig når man skal sammenligne flere populationer med forskellig aldersstruktur, fordi alder har en så stor betydning for risikoen for at få en psykisk sygdom som f. eks. skizofreni. ASR er et vægtet gennemsnit af de aldersspecifikke rater; vægtene er taget fra aldersfordelingen af standard populationen.

\subsubsection{Lovgrundlag for psykiatri i de nordiske lande}

Lovgrundlaget i psykiatrien er forskelligt i de nordiske lande. Derfor er lovgrundlaget for de forskellige nordiske lande beskrevet nedenfor med henvisning til relevante kilder.

\section{Danmark}

Den væsentligste lovgivning vedrørende sundhedsvæsenets indsats i forhold til såvel somatiske som psykiatriske patienter er reguleret i Sundhedsloven, jf. lovbekendtgørelse nr. 913 af 13. juli 2010. Loven trådte i kraft 1. januar 2007 og den omfatter bl.a. patienters retsstilling, den offentlige sygesikring og sygehusvæsenet, forebyggende sundhedsordninger, patientsikkerhed m.v.

Desuden reguleres anvendelse af tvang over for psykiatriske patienter i psykiatriloven, jf. lovbekendtgørelse nr. 1729 af 2. december 2010 
om anvendelse af tvang i psykiatrien. Loven trådte i kraft 1. oktober 1989. r Loven regulerer bl.a. tvangsindlæggelser og fikseringsforanstaltninger samt tvangsprotokol og obligatorisk efterprøvelse, patientrådgivere og klagevejledning m.v. Al tvang i Danmark skal indberettes, og Sundhedsstyrelsen udgiver detaljerede statistikker på området.

Der er til loven tilknyttet følgende bekendtgørelser og vejledninger:

- Bekendtgørelse nr. 1338 af 2. december 2010 som omhandler anvendelse af anden tvang end frihedsberøvelse på psykiatriske afdelinger, herunder tvangsmedicinering, tvungen opfølgning, tvangsfixering og anvendelse af fysisk magt, beskyttelsesfixering, personlige alarmsystemer, personlig afskærmning, personlig hygiejne under anvendelse af tvang m.v.

- Bekendtgørelse nr. 1339 af 2. december 2010 om forretningsorden for de psykiatriske patientklagenævn, som omhandler patientklagenævnets opgaver, forberedelse og afholdelse af møder, afgørelser, tavshedspligt m.v.

- Bekendtgørelse nr. 1340 af 2. december 2010 som omhandler processen ved tvangsindlæggelser, herunder tilkaldelse af læge, den indlæggende læges opgaver, iværksættelse af tvangsindlæggelsen og modtagelse af patienten

- Bekendtgørelse nr. 1341 af 2. december 2010 om patientrådgivere, som omhandler antagelse og beskikkelse af patientrådgivere, opgaver og beføjelser m.v.

- Bekendtgørelse nr. 1342 af 2. december 2010 om tvangsprotokoller og registrering og indberetning af tvang samt udskrivningsaftaler og koordinationsplaner

- Bekendtgørelse nr. 1343 af 2. december 2010 som beskriver underretning og klagevejledning i forbindelse med anvendelse af tvang i psykiatrien

- Bekendtgørelse nr. 1493 af 14. december 2006 som omhandler samtaler efter ophør af en tvangsforanstaltning på psykiatriske afdelinger

- Bekendtgørelse nr. 1494 om undersøgelse af post, patientstuer og ejendele, kropsvisitation samt beslaglæggelse og tilintetgørelse af genstande m.v. på psykiatrisk afdeling

- Vejledning nr. 10575 af 20. december 2006 som omhandler udfyldelse af tvangsprotokoller (registrering af anvendelse af tvang i psykiatrien) samt registrering af anvendelse af udskrivningsaftaler og koordinationsplaner

- Vejledning nr. 1342 af 2. december 2010 til psykiatriske afdelinger, som omhandler vejledning om forhåndstilkendegivelser, behandlingsplaner, eftersamtaler, tvungen opfølgning efter udskrivning, obligatorisk vurdering ved tvangsfiksering, beskyttelsesfiksering, udskrivningsaftaler, koordinationsplaner, 
husordener og klagemuligheder mv. for patienter indlagt på

psykiatriske afdelinger

- lovgrundlagene $^{1}$

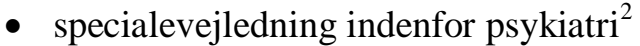

- National strategi for psykiatri, $2009^{3}$

- Aftale om satspuljen på sundhedsområdet 2008-20114

\section{Behandlingsgaranti}

Der er i Danmark udvidet behandlingsret for psykiatriske patienter jf. bekendtgørelse om ret til sygehusbehandling m.v.: Voksne: 2 mdr. Børn: 2 mdr. til udredning og 2 måneder til behandling hvis den psykiatriske undersøgelse har vist, at der er behov for at modtage behandling inden for 2 måneder for at undgå forværring af sygdommen. ${ }^{5}$

\section{Finland}

Mentalvårdslag 14.12.1990/1116. ${ }^{6}$

Mentalvårdslagen är en allmän lag som definierar begrepp, innehåll, övervakning, förpliktelser och principer för tillhandahållandet av mentalvårdstjänster. Dessutom innehåller den specialbestämmelser om statliga psykiatriska sjukhus, vård oberoende av patientens vilja och rättspsykiatriska utredningar.

Lagstiftningen ålägger kommunerna ansvaret för att tillhandahålla mentalvårdstjänster. Kommunerna kan producera mentalvårdstjänsterna antingen inom ramen för sin egen primärvård respektive psykiatriska vård eller köpa dem av sitt sjukvårdsdistrikt eller andra producenter.

\section{Behandlingsgaranti}

Barn og ungdomar under 23 år: Inom 3 månader. Vuxna: Inom 6 månader.

\section{Færøerne}

Lovgivningen vedrørende psykiske lidelser reguleres primært jævnfør Anordning nr. 185 af 13.3.2009 (psykiatriloven) http://www.logir.fo/ foldb/ano/2009/0000185.htm. Desuden er følgende bekendtgørelser gældende:

\footnotetext{
${ }^{1}$ http://www.sst.dk/Planlaegning\%200g\%20kvalitet/Psykiatriomraadet/

Tvang_i_psykiatrien.aspx

2 http://www.psykiatri.rn.dk/NR/rdonlyres/ECEB02C4-2B2B-494B-951C-

BAAD0E8C51D9/0/Specialevejledningforpsykiatrijuni2010.pdf

3 http://www.sst.dk/publ/Publ2009/PLAN/NatStrat_psykiatri09net.pdf

${ }^{4} \mathrm{http}: / /$ www.sum.dk/Puljer/ /media/Filer\%20-\%20dokumenter/

Aftale\%20om\%20satspuljen\%20for\%202008-2011.ashx

${ }^{5}$ http://www.sst.dk/ /media/Behandligsforloeb\%20og\%20rettigheder/

Patientinformation/Pjecer/Frit\%20sygehusvalg\%20pr\%201\%20ja

${ }^{6}$ http://www.finlex.fi/sv/laki/ajantasa/1990/19901116
} 
- Bekendtgørelse nr. 960 af 7. okt. 2009 om tvangsbehandling, fiksering, tvangsprotokoller m.v. http://www.logir.fo/foldb/bek/2009/0000960.htm

- Bekendtgørelse nr. 959 af 7. okt. 2009 om fremgangsmåden ved gennemførelse af tvangsindlæggelser http://www.logir.fo/foldb/bek/2009/0000959.htm

- Bekendtgørelse nr. 957 af 7. okt. 2009 om underretning og klagevejledning i forbindelse med anvendelse af tvang i psykiatrien http://www.logir.fo/foldb/bek/2009/0000957.htm

- Bekendtgørelse nr. 133 af 5. okt. 2009 om forretningsorden for de psykiatriske patientklagenævn http://www.logir.fo/foldb/kunfo/2009/0000133.htm

- Bekendtgørelse nr. 132 af 5. okt. 2009 om patientrådgivere http://www.logir.fo/foldb/kunfo/2009/0000132.htm

- Bekendtgørelse nr. 961 af 7. okt. om samtaler efter ophør af en tvangsforanstaltning på psykiatriske afdelinger http:www.logir.fo/foldb/bek/2009/0000961.htm

\section{Behandlingsgaranti}

Der er ingen behandlingsgaranti.

\section{Grønland}

Grønland fik den 1. januar 2009 lovgivningskompetencen på psykiatriområdet, jfr. lov nr. 1406 af 27. december 2008.

Departementet for Sundhed arbejder på en ny psykiatrilov, der skal erstatte „Lov om sindssyge personers hospitalsophold“, men arbejdet er endnu ikke tilendebragt. Departementet arbejder således fortsat på at løfte den opgave, som blev anbefalet af juragruppen i forbindelse med udarbejdelse af „Redegørelse om hjemtagning af den psykiatriske behandling til Grønland“ (Direktoratet for Sundhed og Forskning, 1998).

For nuværende forbliver Lov om sindssyge personers hospitalsophold lov nr. 118 af 13. april 1938 med senere ændringer gældende for Grønland. Der er i 1986 lavet en sammenskrivning af loven med dens ændringer, jfr. lov nr. 11150 af 31. oktober 1986.

Der er i loven om sindssyge personers hospitalsophold ikke nogen formaliseret klageadgang. Spørgsmål om en anbringelses lovlighed eller en tilbageholdelses lovlighed kan alene prøves for en domstol, men kan ikke forelægges et formelt patientklagenævn.

Direktoratet for Sundhed har i 1996 udarbejdet et cirkulære om frihedsberøvelse ved indlæggelse, ophold og behandling på Dronning Ingrids Hospitals psykiatriske afdeling, jfr. cirkulære nr. 10. Cirkulæret udstikker retningslinjerne for tvangstilbageholdelse, tvangsindlæggelse, tvangsbehandling, tvangsfiksering, anvendelse af fysisk magt, beskyttelsesfiksering, brug af tilsynsværge og tvangsprotokol.

En kriminel, der findes at være psykisk syg, kan i henhold til „Kriminallov for Grønland" fra 2008, kapitel 33 idømmes en psykiatrisk særforanstaltning, når det er fundet nødvendigt for at forebygge, at ger- 
ningsmanden begår yderligere kriminalitet. Den psykiatriske patient kan f.eks. idømmes:

- dom til anbringelse på hospital eller anden institution i Danmark eller Grønland (§ 157, stk. 1)

- dom til behandling på hospital eller anden institution i Danmark eller Grønland (§ 157, stk. 2)

- dom til tilsyn ved Kriminalforsorgen eller en beskikket tilsynsførende (kapitel 28)

Den mest indgribende foranstaltning er dom til anbringelse på psykiatrisk hospital i Danmark, der kan idømmes, hvis der skønnes behov for en egentlig anbringelse på en lukket psykiatrisk afdeling, idet der ikke findes en lukket psykiatrisk afdeling i Grønland. Ved en dom til anbringelse på psykiatrisk hospital kan den pågældende kun udskrives efter rettens kendelse herom.

I kriminalloven er en dom til anbringelse tidsbegrænset til maksimalt 3 år, som dog i særlige tilfælde kan forlænges med yderligere 2 år (§ 158, stk. 1). Dette gælder dog ikke, når den domfældte findes skyldig i alvorlige forbrydelser som drab, røveri, frihedsberøvelse, alvorlig voldsforbrydelse, voldtægt og lign. ( $(158$, stk. 2). I disse tilfælde er anbringelsen almindeligvis tidsubestemt, men skal prøves for retten efter 3 år efter afgørelsen og herefter mindst hvert 2. år. Efter den tidligere kriminallov blev foranstaltninger i henhold til kriminallovens $\S 113$ (nu $\S$ 156) altid idømt uden tidsbegrænsning. ${ }^{7}$

\section{Behandlingsgaranti}

Der er ingen behandlingsgaranti.

\section{Island}

Island har ikke spesiel lov om psykisk helsevern. Loven um helsetjeneste (no. 40/2007) omfatter alle patienter og også lov om patients rettigheder (no 74/1997).

Lov om umyndiggörelse (no. 71/1997) handler om, at hvis en person anses til ikke at have styr på sit liv på grund av blandt andet psykisk sygdom, så kan hun umyndigöres av offentlige myndigheder.

\section{Behandlingsgaranti}

Der er ingen behandlingsgaranti.

\footnotetext{
${ }^{7}$ http://www.justitsministeriet.dk/fileadmin/filer/love/Kriminallov_for_Groenland_dansk_pdf.
} 


\section{Norge}

Lovgrunnlaget for psykisk helsevern finnes i Lov om etablering og gjennomføring av psykisk helsevern (psykisk helsevernloven). ${ }^{8}$

Vilkår for å etablere og opprettholde tvungent psykisk helsevern

- Frivillighet forsøkt eller åpenbart formålsløst

Som i somatikken, er også behandling av psykiske lidelser som hovedregel basert på pasientens samtykke. Tvang er derfor kun et alternativ, hvor frivillighet har vært forsøkt, eller anses åpenbart formålsløst, jf. psykisk helsvernloven (phvl.) § 3-3 første ledd nr. 1.

Hovedvilkår: Alvorlig sinnslidelse

Det er et hovedvilkår at personen har en «alvorlig sinnslidelse» i lovens forstand, jfr. phvl. § 3-3 første ledd nr. 3.

Tilleggsvilkår: Behandling eller fare

Det er ikke tilstrekkelig at det foreligger en alvorlig sinnslidelse. I tillegg må minst ett av to tilleggsvilkår være oppfylt, enten behandlingsvilkåret eller farevilkåret, jfr. Phvl. §§ 3-2/3-3 første ledd nr. 3 bokstav a og b. Det er tilleggsvilkårene som begrunner tvangsinnleggelsen, ikke sinnslidelsen i seg selv.

\section{Helhetsvurdering}

Selv om hoved- og tilleggsvilkår er oppfylt, skal tvungent psykisk helsvern kun etableres hvor dette etter en helhetsvurdering anses som klart beste løsning for vedkommende, jf. phvl. § 3-3 første ledd nr.6.

Tvungen observasjon og tvungent psykisk helsvern

Dersom det er sannsynlighetsovervekt for at vilkårene for tvungent psykisk helsvern er oppfylt, kan det etableres tvungen observasjon etter phvl. § 3-2 (kan vare i 10+10 dager).

Dersom vilkårene er oppfylt, kan det etableres tvungent psykisk helsevern, jf. phvl. § 3-3.

Tvungent psykisk helsevern med eller uten døgnopphold i institusjon Tvungen observasjon og tvungent psykisk helsevern kan omfatte to alternative hovedformer for tvangsvern: Døgnopphold i godkjent institusjon, eller uten døgnopphold under ansvar av godkjent institusjon. Dette reguleres i § 3-5.

\footnotetext{
8 http://www.lovdata.no/cgi-wift/wiftldles?doc=/app/gratis/www/docroot/all/nl-19990702-

062.html\&emne=psykisk*\%20helsevernlov*\&\&
} 


\section{Opprettholdelse}

Opprettholdelse av tvungent psykisk helsevern forutsetter at vilkårene for tvang vurderes å være oppfylt til enhver tid. Vurderingen skal foretas fortløpende, jfr. psykisk helsevernloven § 3-7 første ledd og etableringsforskriftens $§ 7$ første ledd. Faglig ansvarlig skal minst hver tredje måned ved personlig undersøkelse av pasienten, vurdere om vilkårene er oppfylt. Dersom den faglig ansvarlige finner at vilkårene ikke lenger er oppfylt, skal pasienten utskrives, jfr. psykisk helsevernloven § 3-7 annet ledd.

Behandling uten eget samtykke for psykisk lidelse av pasienter under tvungent psykisk helsevern er regulert i § 4-4 med tilhørende forskrift. Bestemmelsen regulerer også tvangsmedisinering.

Klage

Selve vedtaket om tvungen observasjon/ tvungent psykisk helsevern kan påklages til kontrollkommisjonen. Det samme gjelder de fleste vedtakene om tvang etter lovens kapittel 4 . Vedtak om behandling uten eget samtykke skal derimot påklages til Fylkesmannen. ${ }^{9}$

\section{Behandlingsgarantier}

Lov om pasientrettigheter og forskrift om prioritering av helsetjenester er det lovmessige grunnlaget for prioritering av pasienter som henvises til spesialist helsetjenesten.

Pasienten har rett til nødvendig (prioritert) helsehjelp fra spesialisthelse-tjenesten når hvert av følgende vilkår er oppfylt:

- Pasienten har et visst prognosetap med hensyn til levetid, eller ikke ubetydelig nedsatt livskvalitet dersom helsehjelpen utsettes

- Pasienten kan ha forventet nytte av helsehjelpen

- De forventede kostnadene står i rimelig forhold til tiltakets effekt

Voksne som henvises til spesialisthelsetjenesten har rett til å få henvisningen vurdert innen 30 dager. Barn/ungdom under 23 år som henvises spesialisthelsetjenesten med psykiske lidelser og/eller rusproblemer har rett til å få henvisningen vurdert innen 10 dager og nødvendig helsehjelp oppstartet innen 65 dager.

Pasienter som får rett til nødvendig helsehjelp skal få en medisinsk forsvarlig frist for når helsehjelpen senest skal starte. Det er denne fristen som er angitt i veiledertabellen:

- http://www.helsedirektoratet.no/publikasjoner/veiledere/prioriteri ngsveileder_psykisk_helsevern_for_voksne_292724

\footnotetext{
${ }^{9}$ http://www.helsedirektoratet.no/psykisk_helse_tjenesten/kontrollkommisjonen/

rettssikkerhet_ved_tvang_37032
} 
- http://www.helsedirektoratet.no/publikasjoner/veiledere/veiledert abell__psykisk_helsevern_for_voksne_293644

- http://www.helsedirektoratet.no/publikasjoner/veiledere/prioriteri ngsveileder_psykisk_helsevern_for_barn_og_unge_380234

- http://www.helsedirektoratet.no/publikasjoner/veiledere/veiledert abell__psykisk_helsevern_for_barn_og_unge_380214

\section{Sverige}

De lagliga grunderna för den psykiatriska hälso- och sjukvården

\section{Hälso- och sjukvårdslagen}

Den grundläggande regleringen av hälso- och sjukvården finns i hälso- och sjukvårdslagen (HSL 1982:763), som också är tillämplig på all psykiatrisk vård. Enligt HSL gäller en allmän skyldighet att erbjuda en god vård på lika villkor. Det gäller även om man under en tid måste vårda någon med tvång. Grundförutsättningarna för en god vård anges i 2 a § HSL.

Enligt denna skall hälso- och sjukvården bedrivas så att den uppfyller kraven på en god vård. Detta innebär att den skall särskilt:

- vara av god kvalitet med en god hygienisk standard och tillgodose patientens behov av trygghet i vården och behandlingen

- vara lätt tillgänglig

- bygga på respekt för patientens självbestämmande

- främja goda kontakter mellan patienten och hälso- och

- sjukvårdspersonalen tillgodose patientens behov av kontinuitet och säkerhet i vården

I HSL betonas särskilt vikten av förebyggande insatser mot ohälsa. Detta har stor betydelse för psykiatrins inriktning och fortsatta utveckling.

Tidigt insatta och förebyggande åtgärder kan förhindra en framtida tvångsintagning. Den 1 januari 2011 trädde en ny Patientsäkerhetslag i kraft som bland annat reglerar att patienten har rätt till individuellt anpassad information om sitt hälsotillstånd och om vilka metoder för undersökning, vård och behandling som föreligger.

\section{Psykiatrisk tvångsvård}

Ändamålet med tvångsvård är att se till att den som har ett oundgängligt behov av psykiatrisk heldygnsvård på en sjukvårdsinrättning blir i stånd att frivilligt medverka till fortsatta stöd- och behandlingsinsatser. Villkoren för tvångsvård är utformade med sikte på att begränsa tvångsvården till vad som är oundgängligen nödvändigt. Psykiatrisk tvångsvård kan ges med stöd av lagen om psykiatrisk tvångsvård (LPT 1991:1128) och lagen om rättspsykiatrisk vård (LPT 1991:1129). Tvångsvård får ges endast om patienten lider av en allvarlig psykisk störning och på grund av sitt psykiska tillstånd och i sina personliga förhållanden i övrigt: 
- Har ett oundgängligt behov av psykiatrisk vård, som inte kan tillgodoses på annat sätt än genom att patienten är intagen på en sjukvårdsinrättning för kvalificerad psykiatrisk dygnetruntvård (sluten psykiatrisk tvångsvård), eller

- Behöver iaktta särskilda villkor för att kunna ges nödvändigpsykiatrisk vård (öppen psykiatrisk tvångsvård)

En förutsättning för vård enligt denna lag är att patienten motsätter sig vård, eller tillföljd av patienternas psykiska tillstånd finns grundad anledning att anta att vården inte kan ges med hans eller hennes samtycke. Ett beslut om intagning på en sjukvårdsinrättning för tvångsvård får inte fattas utan att ett läkarintyg (vårdintyg) har utfärdats, av vilket det framgår att det finns sannolika skäl för att förutsättningarna för sluten psykiatrisk tvångsvård av patienten är uppfyllda. Vårdintyget ska grundas på en särskild läkarundersökning.

Öppen psykiatrisk tvångsvård och öppen rättspsykiatrisk vård

Den 1 september 2008 infördes nya bestämmelser om en ny vårdform öppen psykiatrisk tvångsvård och öppen rättspsykiatrisk vård - i LPT och LRV. Den nya vårdformen får bedrivas utanför sjukvårdsinrättningen och förutsätter bl.a. att patienten behöver iaktta särskilda villkor för att kunna ges nödvändig psykiatrisk vård.

Tvångsåtgärder får inte förekomma inom ramen för den öppna psykiatriska tvångsvården. Både vid permissioner och vid vård i den nya vårdformen förutsätts att läkare och patient i stora delar är överens om det faktiska innehållet i de insatser som ska ges.

Svensk lagstiftning finns tillgänglig på Internet.10

\section{Behandlingsgaranti}

Den specialiserade barn- och ungdomspsykiatrin ska kunna erbjuda tid för bedömning inom högst 30 dagar och därefter beslutad fördjupad utredning/behandling inom högst 30 dagar. Vuxna: Efter beslut om remiss ska ett besök inom den specialiserade vården kunna erbjudas inom högst 90 dagar efter beslutsdatum. Efter beslut om behandling/åtgärd ska denna erbjudas inom högst 90 dagar. ${ }^{11}$

${ }^{10} \mathrm{http}: / /$ www.lagrummet.se

${ }^{11}$ www.vantetider.se/vad-aer-vaardgarantin 


\section{Referencer}

1. Nordisk kvalitetsmåling i sundhedsvæsenet TemaNord 2010:572

2. Kvalitetsmåling i sundhedvæsenet $i$ Norden, TemaNord 2007:519

3. Health at a Glance 2009: OECD Indicators, OECD 2009

4. Adaptation of the OECD (2006) Conceptual Framework for the OECD Health Care Quality Indicators Project, OECD Health Working Paper, No. 23, OECD Publishing, Paris. Health at a Glance 2009: OECD Indicators (C) OECD 2009 Mainz J. Defining and classifying clinical indicators for quality improvement. International journal for quality in healthcare 2003; 15: 6: 523-530.

5. Rubin HR. Provonost P. Diette Gb. From a process of care to a measure: The development and testing off a quality indicator. International Journal for Quality and healthcare 2001; 13: 489-496.

6. McGlynn EA. The outcomes utility index: will outcomes data tell us what we want to know? International Journal for Quality and healthcare 1998; 10: 485-490.

7. McGlynn EA. Asch SM. Developing a clinic performance measure. AM J Paed MED. 1998; 14: 14-21.

8. Mainz J. Developing Evidence-based clinical indicators: A state of the art methods primer. International journal for quality for healthcare 2003 ; 15 . supplement 1 : I $5-$ I 11.

9. Mainz J. Quality Indicators. Essential for quality improvement. International Journal for Quality and healthcare 2004; 16: Supplement 1: I1-I2

10. Rubin HR. Provonost P. Diette Gb. The advantages and disadvantages of processbased measures off healthcare quality. International Journal for Quality and healthcare 2001; 13: 469-474. 



\section{Kapitel}

\subsection{Valg af prioriterede og potentielle kvalitetsindikatorer}

Som det fremgår af arbejdsgruppens kommissorium, skulle arbejdsgruppen udvælge og videreudvikle et sæt af fællesnordiske kvalitetsindikatorer. I forlængelse heraf besluttede arbejdsgruppen at inkludere kvalitetsindikatorer, som allerede var implementeret i de enkelte nordiske lande. Ligeledes besluttede arbejdsgruppen, at kvalitetsindikatorer, som var under implementering, eller som det var besluttet at implementere skulle indgå i et fællesnordisk indikatorsæt som potentielle kvalitetsindikatorer.

Endvidere skulle tidligere valgte fællesnordiske kvalitetsindikatorer indgå $\mathrm{i}$ arbejdsgruppens grundlag.

Endelig skulle relevante OECD-indikatorer, der kunne belyse det psykiatriske område, inkluderes i det fællesnordiske ndikatorsæt.

\subsubsection{Generelle kommentarer til sammenlignelighed}

En sammenligning af resultater for kvalitetsindikatorer forudsætter, at resultaterne kommer fra sammenlignelige systemer, f.eks. at befolkningsgrundlaget er ensartet sammensat, og at vilkårene for den organisatoriske tilrettelæggelse af sundhedsvæsenet er ensartede.

I indeværende rapport er kvalitetsindikatorer opgjort i forhold til Danmark, Finland, Færøerne, Grønland, Island, Norge og Sverige.

Det må her konstateres, at eventuelle forskelle i resultater for kvalitetsindikatorer mellem de små lande som Færøerne, Grønland og Island og de større lande som Danmark, Norge og Sverige kan afspejle forskelle i geografiske/demografiske forhold og ikke nødvendigvis forskelle i kvaliteten for området. Her bør der i fortolkningen af indeværende rapports tabeller tages højde for de store forskelle i befolkningstal, hvor især de små landes resultater er behæftet med betydelig usikkerhed grundet lille befolkningstal.

I indeværende rapport har det ikke været muligt for Island, at levere alle tilgængelige data, derfor afspejler N/A i tabellerne denne faktor.

Datagrundlaget for Færøerne er generelt set for indlagte patienter og indeholder ikke data for ambulante patienter. 


\subsubsection{Betydning af sammenlignelige datakilder}

Sammenligning kræver ideelt set også ensartede datakilder. I indeværende rapport er disse ideelle betingelser ikke opfyldt. Datakilder i kapitlet svinger fra data indsamlet fra kvalitetsregistre dedikeret den givne sygdom til patientadministrative systemer, ligesom opgørelsesårene er forskellige i flere tilfælde.

\subsubsection{Datakvalitet}

Datakvaliteten bør være ensartet $h ø j$ - herunder samme opgørelsesperiode samt specificeret høj data- og databasekomplethed, før resultaterne sammenlignes.

Data fra Norge vedrørende diagnosticerede patienter med henholdsvis skizofreni, ADHD, bipolar lidelse og depression samt patienter under 18 år, der er diagnostisk vurderet, er imidlertid overestimerede. Tallene i rapporten er baseret på, at 185.671 patienter var i behandling i Norge i 2009. Efterfølgende er der gennemført en revidering af tallene, som viser, at der i stedet er 171.241 patienter i behandling i Norge i 2009, hvilket svarer til en reduktion i antal patienter på 7,8 procent. Som en gennemsnitsbetragtning kan man derfor gå ud fra, at data for de før nævnte indikator har en overrapportering på omkring 5 til 10 procent.

\subsubsection{Valg af potentielle kvalitetsindikatorer}

Udover resultater er der som afslutning for nogle af sygdomsområderne specificeret potentielle indikatorer, der som tidligere anført er under implementering i et af de nordiske lande.

Nedenfor beskrives indikatorer for de valgte sygdomsområder. 


\subsection{Skizofreni - voksne}

\begin{tabular}{|c|c|c|c|c|c|c|}
\hline Land & $\begin{array}{r}\text { Antal nydiag- } \\
\text { nosticerede } \\
\text { patienter med } \\
\text { skizofreni med } \\
\text { kontakt til } \\
\text { sekundær } \\
\text { sektor pr. år } \\
\text { (Samlet) }\end{array}$ & $\begin{array}{r}\text { Samlet antal } \\
\text { nydiagnostice- } \\
\text { rede patienter } \\
\text { med skizofreni } \\
\text { med kontakt } \\
\text { til sekundær } \\
\text { sektor pr. } \\
100.000 \\
\text { indbyggere pr. } \\
\text { år (Samlet) }\end{array}$ & $\begin{array}{r}\text { Antal nydiag- } \\
\text { nosticerede } \\
\text { patienter med } \\
\text { skizofreni med } \\
\text { kontakt til } \\
\text { sekundær } \\
\text { sektor pr. år } \\
\text { (Mænd) }\end{array}$ & $\begin{array}{r}\text { Samlet antal } \\
\text { nydiagnostice- } \\
\text { rede patienter } \\
\text { med skizofreni } \\
\text { med kontakt } \\
\text { til sekundær } \\
\text { sektor pr. } \\
100.000 \\
\text { indbyggere pr. } \\
\text { år (Mænd) }\end{array}$ & $\begin{array}{r}\text { Antal nydiag- } \\
\text { nosticerede } \\
\text { patienter med } \\
\text { skizofreni med } \\
\text { kontakt til } \\
\text { sekundær } \\
\text { sektor pr. år } \\
\text { (Kvinder) }\end{array}$ & $\begin{array}{r}\text { Samlet antal } \\
\text { nydiagnostice- } \\
\text { rede patienter } \\
\text { med skizofreni } \\
\text { med kontakt til } \\
\text { sekundær } \\
\text { sektor pr. } \\
100.000 \text { indbyg- } \\
\text { gere pr. år } \\
\text { (Kvinder) }\end{array}$ \\
\hline Danmark & 1377 & 32,0 & 824 & 39,0 & 553 & 25,2 \\
\hline Finland & 1541 & 28,8 & 875 & 33,3 & 666 & 24,4 \\
\hline Færøerne & 1,6 & 3,3 & 1,0 & 4,0 & 0,6 & 2,4 \\
\hline Grønland & N/A & N/A & N/A & $\mathrm{N} / \mathrm{A}$ & N/A & N/A \\
\hline Island & $\mathrm{N} / \mathrm{A}$ & N/A & $\mathrm{N} / \mathrm{A}$ & N/A & $\mathrm{N} / \mathrm{A}$ & $\mathrm{N} / \mathrm{A}$ \\
\hline Norge & $\mathrm{N} / \mathrm{A}$ & N/A & $\mathrm{N} / \mathrm{A}$ & N/A & $\mathrm{N} / \mathrm{A}$ & N/A \\
\hline Sverige & 5573 & 75,6 & 3317 & 91,2 & 2256 & 60,4 \\
\hline
\end{tabular}

Anm.: For Færøerne er tallene baseret på et gennemsnit for 2005-2009. I Sverige er nydiagnosticerede beregnet som patienter, der ikke har haft en diagnose et år inden indskrivningsdato/bes $\varnothing$ gsdato. Finland og Færøerne har anvendt hele befolkningen som grundlag. Tallene for Finland er for indlagte.

Bemærkninger: Resultaterne for nydiagnosticerede skizofrenipatienter er ikke sammenlignelige. Færøerne har et lille datagrundlag jf. de indledende kommentarer. Sverige har beregnet nydiagnosticerede ud fra en definition, de betyder, at flere patienter indgår. Tallene fra Finland er for indlagte patienter. Endvidere har Finland anvendt hele befolkningen som grundlag for tallene pr. 100.000 indbyggere, hvilket betyder, at tallene bliver underestimerede. Generelt er der flere mænd end kvinder, der bliver nydiagnosticeret med skizofreni. Tallene for Færøerne er baseret på indlagte patienter.

Tabel 2.2.2. Indlagte og ambulante nydiagnosticerede patienter med skizofreni - basisindikatorer

\begin{tabular}{|c|c|c|c|c|c|c|}
\hline Land & $\begin{array}{r}\text { Antal indlagte } \\
\text { nydiagnostice- } \\
\text { rede patienter } \\
\text { med skizofreni } \\
\text { med kontakt } \\
\text { til sekundær } \\
\text { sektor pr. } \\
100.000 \\
\text { indbyggere pr. } \\
\text { år (Samlet) }\end{array}$ & $\begin{array}{r}\text { Antal indlagte } \\
\text { nydiagnostice- } \\
\text { rede patienter } \\
\text { med skizofreni } \\
\text { med kontakt } \\
\text { til sekundær } \\
\text { sektor pr. } \\
100.000 \\
\text { indbyggere pr. } \\
\text { år (Mænd) }\end{array}$ & $\begin{array}{r}\text { Antal indlagte } \\
\text { nydiagnostice- } \\
\text { rede patienter } \\
\text { med skizofreni } \\
\text { med kontakt } \\
\text { til sekundær } \\
\text { sektor pr. } \\
100.000 \\
\text { indbyggere pr. } \\
\text { år (Kvinder) }\end{array}$ & $\begin{array}{r}\text { Antal ambu- } \\
\text { lante nydiag- } \\
\text { nosticerede } \\
\text { patienter med } \\
\text { skizofreni med } \\
\text { kontakt til } \\
\text { sekundær } \\
\text { sektor pr. } \\
100.000 \\
\text { indbyggere pr. } \\
\text { år (Samlet) }\end{array}$ & $\begin{array}{r}\text { Antal ambu- } \\
\text { lante nydiag- } \\
\text { nosticerede } \\
\text { patienter med } \\
\text { skizofreni med } \\
\text { kontakt til } \\
\text { sekundær } \\
\text { sektor pr. } \\
100.000 \\
\text { indbyggere pr. } \\
\text { år (Mænd) }\end{array}$ & $\begin{array}{r}\text { Antal ambulan- } \\
\text { te nydiagnosti- } \\
\text { cerede patien- } \\
\text { ter med skizo- } \\
\text { freni med } \\
\text { kontakt til } \\
\text { sekundær } \\
\text { sektor pr. } \\
100.000 \text { indbyg } \\
\text { gere pr. år } \\
\text { (Kvinder) }\end{array}$ \\
\hline Danmark & 18,3 & 22,1 & 14,5 & 25,7 & 31,1 & 20,4 \\
\hline Finland & 28,8 & 33,3 & 24,4 & N/A & $\mathrm{N} / \mathrm{A}$ & $\mathrm{N} / \mathrm{A}$ \\
\hline Færøerne & 3,3 & 4,0 & 2,4 & N/A & N/A & $\mathrm{N} / \mathrm{A}$ \\
\hline Grønland & 24,4 & 13,6 & 37,1 & N/A & N/A & $\mathrm{N} / \mathrm{A}$ \\
\hline Island & N/A & $\mathrm{N} / \mathrm{A}$ & N/A & N/A & N/A & $\mathrm{N} / \mathrm{A}$ \\
\hline Norge & N/A & N/A & N/A & N/A & N/A & $\mathrm{N} / \mathrm{A}$ \\
\hline Sverige & 29,6 & 36,2 & 23,1 & 73,1 & 88,0 & 58,4 \\
\hline
\end{tabular}

Anm.: For Færøerne er tallene baseret på et gennemsnit for 2005-2009. I Sverige er nydiagnosticerede beregnet som patienter, der ikke har haft en diagnose et år inden indskrivningsdato/bes $\varnothing g s d a t o$. Finland og Færøerne har anvendt hele befolkningen som grundlag.

Bemærkninger: Resultaterne for indlagte patienter er ikke sammenlignelige. Færøerne og Grønland har et lille datagrundlag jf. de indledende kommentarer. Sverige har beregnet nydiagnosticerede ud fra en anden definition, hvilket betyder at flere patienter indgår. Finland og Færøerne har anvendt hele befolkningen som grundlag for tallene pr. 100.000 , hvilket betyder at tallene bliver underestimerede. Generelt kan det siges, at der for alle landene med undtagelse af Grønland gælder, at flere mænd end kvinder er nydiagnosticeret med skizofreni (indlagte). Resultater for ambulante er ikke sammenlignelige pga. forskelle i opgørelse af nydiagnosticerede. Generelt er der flere nydiagnosticerede ambulante mænd med skizofreni end kvinder. Tallene for Færøerne er baseret på indlagte patienter. 
Tabel 2.2.3. Nydiagnosticerede patienter med skizofreni og misbrugsdiagnose - basisindikatorer

\begin{tabular}{|c|c|c|c|c|c|c|}
\hline Land & $\begin{array}{r}\text { Antal nydiag- } \\
\text { nosticerede } \\
\text { patienter med } \\
\text { skizofreni og } \\
\text { misbrugsdi- } \\
\text { agnose med } \\
\text { kontakt til } \\
\text { sekundær } \\
\text { sektor pr. år } \\
\text { (Samlet) }\end{array}$ & $\begin{array}{r}\text { Samlet antal } \\
\text { nydiagnosti- } \\
\text { cerede } \\
\text { patienter med } \\
\text { skizofreni og } \\
\text { misbrugsdi- } \\
\text { agnose med } \\
\text { kontakt til } \\
\text { sekundær } \\
\text { sektor pr. } \\
100.000 \\
\text { indbyggere } \\
\text { pr. år (Samlet) }\end{array}$ & $\begin{array}{r}\text { Antal nydiag- } \\
\text { nosticerede } \\
\text { patienter med } \\
\text { skizofreni og } \\
\text { misbrugsdi- } \\
\text { agnose med } \\
\text { kontakt til } \\
\text { sekundær } \\
\text { sektor pr. år } \\
\text { (Mænd) }\end{array}$ & $\begin{array}{r}\text { Samlet antal } \\
\text { nydiagnosti- } \\
\text { cerede } \\
\text { patienter med } \\
\text { skizofreni og } \\
\text { misbrugsdi- } \\
\text { agnose med } \\
\text { kontakt til } \\
\text { sekundær } \\
\text { sektor pr. } \\
100.000 \\
\text { indbyggere } \\
\text { pr. år (Mænd) }\end{array}$ & $\begin{array}{r}\text { Antal nydiag- } \\
\text { nosticerede } \\
\text { patienter med } \\
\text { skizofreni og } \\
\text { misbrugsdi- } \\
\text { agnose med } \\
\text { kontakt til } \\
\text { sekundær } \\
\text { sektor pr. år } \\
\text { (Kvinder) }\end{array}$ & $\begin{array}{r}\text { Samlet antal } \\
\text { nydiagnosticere- } \\
\text { de patienter } \\
\text { med skizofreni } \\
\text { og misbrugsdi- } \\
\text { agnose med } \\
\text { kontakt til } \\
\text { sekundær sektor } \\
\text { pr. } 100.000 \\
\text { indbyggere pr. år } \\
\text { (Kvinder) }\end{array}$ \\
\hline Danmark & 175 & 4,1 & 144 & 3,3 & 31 & 0,7 \\
\hline Finland & 38 & 0,7 & 30 & 1,1 & 8 & 0,3 \\
\hline Færøerne & $\mathrm{N} / \mathrm{A}$ & N/A & $\mathrm{N} / \mathrm{A}$ & $\mathrm{N} / \mathrm{A}$ & $\mathrm{N} / \mathrm{A}$ & N/A \\
\hline Grønland & N/A & N/A & $\mathrm{N} / \mathrm{A}$ & $\mathrm{N} / \mathrm{A}$ & N/A & N/A \\
\hline Island & $\mathrm{N} / \mathrm{A}$ & N/A & $\mathrm{N} / \mathrm{A}$ & $\mathrm{N} / \mathrm{A}$ & $\mathrm{N} / \mathrm{A}$ & N/A \\
\hline Norge & N/A & N/A & N/A & $\mathrm{N} / \mathrm{A}$ & $\mathrm{N} / \mathrm{A}$ & N/A \\
\hline Sverige & 565 & 7,7 & 465 & 12,8 & 100 & 2,7 \\
\hline
\end{tabular}

Anm.: I Sverige er nydiagnosticerede beregnet som patienter, der ikke har haft en diagnose et år inden indskrivningsdato/bes $\emptyset$ gsdato. Finland har anvendt hele befolkningen som grundlag. Endvidere indeholder tal fra Finland indlagte og ikke ambulante patienter.

Bemærkninger: Tallene for nydiagnosticerede skizofrenipatienter med misbrugsdiagnose er ikke sammenlignelige, da Sverige har anvendt en anden opg ørelsesmetode og tallene for Finland er for indlagte patienter. Generelt for de tre lande er der flere nydiagnosticere mænd end kvinder med skizofreni og misbrugsdiagnose.

Tabel 2.2.4. Indlagte og ambulante nydiagnosticerede patienter med skizofreni og misbrugsdiagnose - basisindikatorer

\begin{tabular}{|c|c|c|c|c|c|c|}
\hline Land & $\begin{array}{r}\text { Antal indlagte } \\
\text { nydiagnostice- } \\
\text { rede patienter } \\
\text { med skizofreni } \\
\text { og misbrugs- } \\
\text { diagnose med } \\
\text { kontakt til } \\
\text { sekundær } \\
\text { sektor pr. } \\
100.000 \\
\text { indbyggere pr. } \\
\text { år (Samlet) }\end{array}$ & $\begin{array}{r}\text { Antal indlagte } \\
\text { nydiagnostice- } \\
\text { rede patienter } \\
\text { med skizofreni } \\
\text { og misbrugs- } \\
\text { diagnose med } \\
\text { kontakt til } \\
\text { sekundær } \\
\text { sektor pr. } \\
100.000 \\
\text { indbyggere pr. } \\
\text { år (Mænd) }\end{array}$ & $\begin{array}{r}\text { Antal indlagte } \\
\text { nydiagnostice- } \\
\text { rede patienter } \\
\text { med skizofreni } \\
\text { og misbrugs- } \\
\text { diagnose med } \\
\text { kontakt til } \\
\text { sekundær } \\
\text { sektor pr. } \\
100.000 \\
\text { indbyggere pr. } \\
\text { år (Kvinder) }\end{array}$ & $\begin{array}{r}\text { Antal ambu- } \\
\text { lante nydiag- } \\
\text { nosticerede } \\
\text { patienter med } \\
\text { skizofreni og } \\
\text { misbrugsdiag- } \\
\text { nose med } \\
\text { kontakt til } \\
\text { sekundær } \\
\text { sektor pr. } \\
100.000 \\
\text { indbyggere pr. } \\
\text { år (Samlet) }\end{array}$ & $\begin{array}{r}\text { Antal ambu- } \\
\text { lante nydiag- } \\
\text { nosticerede } \\
\text { patienter med } \\
\text { skizofreni og } \\
\text { misbrugsdiag- } \\
\text { nose med } \\
\text { kontakt til } \\
\text { sekundær } \\
\text { sektor pr. } \\
100.000 \\
\text { indbyggere pr. } \\
\text { år (Mænd) }\end{array}$ & $\begin{array}{r}\text { Antal ambu- } \\
\text { lante nydiag- } \\
\text { nosticerede } \\
\text { patienter med } \\
\text { skizofreni og } \\
\text { misbrugsdiag- } \\
\text { nose med } \\
\text { kontakt til } \\
\text { sekundær } \\
\text { sektor pr. } \\
100.000 \\
\text { indbyggere pr. } \\
\text { år (Kvinder) }\end{array}$ \\
\hline Danmark & 2,3 & 3,9 & 0,8 & 2,4 & 3,8 & 1,1 \\
\hline Finland & 0,7 & 1,1 & 0,3 & N/A & N/A & N/A \\
\hline Færøerne & N/A & N/A & N/A & $\mathrm{N} / \mathrm{A}$ & N/A & N/A \\
\hline Grønland & N/A & N/A & N/A & N/A & N/A & N/A \\
\hline Island & N/A & N/A & N/A & N/A & N/A & N/A \\
\hline Norge & N/A & N/A & N/A & N/A & N/A & $\mathrm{N} / \mathrm{A}$ \\
\hline Sverige & 3,7 & 6,4 & 1,1 & 4,9 & 7,9 & 1,9 \\
\hline
\end{tabular}

Anm.: I Sverige er nydiagnosticerede beregnet som patienter, der ikke har haft en diagnose et år inden indskrivningsdato/besøgsdato. Finland har anvendt hele befolkningen som grundlag frem for $18+$ befolkningen.

Bemærkninger:Resultaterne for nydiagnosticerede indlagte skizofrenipatienter med misbrugsdiagnose er ikke sammenlignelige, da Sverige har anvendt en anden opgørelsesmetode end Danmark, og Finland har anvendt hele befolkningen frem for den voksne befolkning. Generelt for de tre lande er der flere indlagte nydiagnosticere mænd end kvinder med skizofreni og misbrugsdiagnose. Resultater for ambulante nydiagnosticerede skizofrenipatienter med misbrugsdiagnose er ikke sammenlignelige. Generelt er der flere ambulante nydiagnosticerede mænd end kvinder med skizofreni og misbrugsdiagnose. 
Tabel 2.2.5. Diagnosticerede patienter med skizofreni 2009 (Samlet) - basisindikatorer

\begin{tabular}{|c|c|c|c|c|c|c|}
\hline Land & $\begin{array}{r}\text { Antal } \\
\text { diagnostice- } \\
\text { rede patien- } \\
\text { ter med } \\
\text { skizofreni, } \\
\text { som har haft } \\
\text { kontakt med } \\
\text { sekundær } \\
\text { sektor pr. } \\
100.000 \\
\text { indbyggere } \\
\text { pr. år (18+) }\end{array}$ & $\begin{array}{r}\text { Antal } \\
\text { diagnostice- } \\
\text { rede patien- } \\
\text { ter med } \\
\text { skizofreni, } \\
\text { som har haft } \\
\text { kontakt med } \\
\text { sekundær } \\
\text { sektor pr. } \\
100.000 \\
\text { indbyggere } \\
\text { pr. år (18- } \\
24)\end{array}$ & $\begin{array}{r}\text { Antal } \\
\text { diagnostice- } \\
\text { rede patien- } \\
\text { ter med } \\
\text { skizofreni, } \\
\text { som har haft } \\
\text { kontakt med } \\
\text { sekundær } \\
\text { sektor pr. } \\
100.000 \\
\text { indbyggere } \\
\text { pr. år (25- } \\
44)\end{array}$ & $\begin{array}{r}\text { Antal } \\
\text { diagnostice- } \\
\text { rede patien- } \\
\text { ter med } \\
\text { skizofreni, } \\
\text { som har haft } \\
\text { kontakt med } \\
\text { sekundær } \\
\text { sektor pr. } \\
100.000 \\
\text { indbyggere } \\
\text { pr. år (45- } \\
64)\end{array}$ & $\begin{array}{r}\text { Antal } \\
\text { diagnostice- } \\
\text { rede patien- } \\
\text { ter med } \\
\text { skizofreni, } \\
\text { som har haft } \\
\text { kontakt med } \\
\text { sekundær } \\
\text { sektor pr. } \\
100.000 \\
\text { indbyggere } \\
\text { pr. år (65- } \\
84)\end{array}$ & $\begin{array}{r}\text { Antal } \\
\text { diagnostice- } \\
\text { rede patien- } \\
\text { ter med } \\
\text { skizofreni, } \\
\text { som har haft } \\
\text { kontakt med } \\
\text { sekundær } \\
\text { sektor pr. } \\
100.000 \\
\text { indbyggere } \\
\text { pr. år (85+) }\end{array}$ \\
\hline Danmark & 166,5 & 229,2 & 232,0 & 156,5 & 45,9 & 17,5 \\
\hline Finland & 210,9 & 118,5 & 356,4 & 305,1 & 119,7 & 11,9 \\
\hline Færøerne & 78,1 & 69,0 & 134 & 122,1 & 44,9 & 118,4 \\
\hline Grønland & $\mathrm{N} / \mathrm{A}$ & N/A & $\mathrm{N} / \mathrm{A}$ & N/A & N/A & N/A \\
\hline Island & $\mathrm{N} / \mathrm{A}$ & N/A & N/A & N/A & N/A & N/A \\
\hline Norge & 159,3 & 122,8 & 221,6 & 165,7 & 58,2 & 12,9 \\
\hline Sverige & 169,3 & 44,5 & 171,1 & 262,2 & 109,8 & 21,1 \\
\hline
\end{tabular}

Anm.: For Finland og Færøerne er der anvendt hele befolkningen som grundlag. Ø vrige lande har anvendt 18+. Endvidere er aldersgruppen 18-24 år erstattet af 15-24 år for Finland. For Færøerne er tallene baseret på et gennemsnit for 2005-2009. Resultater fra Norge er overestimeret jf. indledende kommentarer.

Bemærkning: Tallene for Færøerne er baseret på indlagte patienter.

Tabel 2.2.6. Diagnosticerede patienter med skizofreni 2009 (Mænd) - basisindikatorer

\begin{tabular}{|c|c|c|c|c|c|c|}
\hline Land & $\begin{array}{r}\text { Antal } \\
\text { diagnostice- } \\
\text { rede patien- } \\
\text { ter med } \\
\text { skizofreni, } \\
\text { som har haft } \\
\text { kontakt med } \\
\text { sekundær } \\
\text { sektor pr. } \\
100.000 \\
\text { indbyggere } \\
\text { pr. år (18+) }\end{array}$ & $\begin{array}{r}\text { Antal } \\
\text { diagnostice- } \\
\text { rede patien- } \\
\text { ter med } \\
\text { skizofreni, } \\
\text { som har haft } \\
\text { kontakt med } \\
\text { sekundær } \\
\text { sektor pr. } \\
100.000 \\
\text { indbyggere } \\
\text { pr. år (18- } \\
24)\end{array}$ & $\begin{array}{r}\text { Antal } \\
\text { diagnostice- } \\
\text { rede patien- } \\
\text { ter med } \\
\text { skizofreni, } \\
\text { som har haft } \\
\text { kontakt med } \\
\text { sekundær } \\
\text { sektor pr. } \\
100.000 \\
\text { indbyggere } \\
\text { pr. år (25- } \\
44)\end{array}$ & $\begin{array}{r}\text { Antal } \\
\text { diagnostice- } \\
\text { rede patien- } \\
\text { ter med } \\
\text { skizofreni, } \\
\text { som har haft } \\
\text { kontakt med } \\
\text { sekundær } \\
\text { sektor pr. } \\
100.000 \\
\text { indbyggere } \\
\text { pr. år (45- } \\
64)\end{array}$ & $\begin{array}{r}\text { Antal } \\
\text { diagnostice- } \\
\text { rede patien- } \\
\text { ter med } \\
\text { skizofreni, } \\
\text { som har haft } \\
\text { kontakt med } \\
\text { sekundær } \\
\text { sektor pr. } \\
100.000 \\
\text { indbyggere } \\
\text { pr. år (65- } \\
84)\end{array}$ & $\begin{array}{r}\text { Antal } \\
\text { diagnostice- } \\
\text { rede patien- } \\
\text { ter med } \\
\text { skizofreni, } \\
\text { som har haft } \\
\text { kontakt med } \\
\text { sekundær } \\
\text { sektor pr. } \\
100.000 \\
\text { indbyggere } \\
\text { pr. år (85+) }\end{array}$ \\
\hline Danmark & 204,6 & 250,8 & 299,3 & 184,7 & 37,9 & 9,1 \\
\hline Finland & 245,7 & 142,4 & 455,8 & 319,3 & 102,6 & 7,1 \\
\hline Færøerne & 84,3 & 101,1 & 183,2 & 88,1 & 28,9 & 0,0 \\
\hline Grønland & N/A & N/A & N/A & $\mathrm{N} / \mathrm{A}$ & N/A & N/A \\
\hline Island & N/A & N/A & N/A & N/A & N/A & N/A \\
\hline Norge & 209,0 & 158,4 & 306,3 & 196,0 & 56,4 & 12,2 \\
\hline Sverige & 206,8 & 60,0 & 226,1 & 317,7 & 97,8 & 14,8 \\
\hline
\end{tabular}

Anm.: For Finland og Færøerne er der anvendt hele befolkningen som grundlag. $\varnothing$ vrige lande har anvendt 18+ befolkning. Endvidere er aldersgruppen 18-24 år erstattet af 1524 år for Finland. For Færøerne er tallene baseret på et gennemsnit for 2005-2009. Resultater fra Norge er overestimeret jf. indledende kommentarer.

Bemærkning: Tallene for Færøerne er baseret på indlagte patienter. 
Tabel 2.2.7. Diagnosticerede patienter med skizofreni 2009 (Kvinder) - basisindikatorer

\begin{tabular}{|c|c|c|c|c|c|c|}
\hline Land & $\begin{array}{r}\text { Antal } \\
\text { diagnostice- } \\
\text { rede patien- } \\
\text { ter med } \\
\text { skizofreni, } \\
\text { som har haft } \\
\text { kontakt med } \\
\text { sekundær } \\
\text { sektor pr. } \\
100.000 \\
\text { indbyggere } \\
\text { pr. år (18+) }\end{array}$ & $\begin{array}{r}\text { Antal } \\
\text { diagnostice- } \\
\text { rede patien- } \\
\text { ter med } \\
\text { skizofreni, } \\
\text { som har haft } \\
\text { kontakt med } \\
\text { sekundær } \\
\text { sektor pr. } \\
100.000 \\
\text { indbyggere } \\
\text { pr. år (18- } \\
24)\end{array}$ & $\begin{array}{r}\text { Antal } \\
\text { diagnostice- } \\
\text { rede patien- } \\
\text { ter med } \\
\text { skizofreni, } \\
\text { som har haft } \\
\text { kontakt med } \\
\text { sekundær } \\
\text { sektor pr. } \\
100.000 \\
\text { indbyggere } \\
\text { pr. år (25- } \\
44)\end{array}$ & $\begin{array}{r}\text { Antal } \\
\text { diagnostice- } \\
\text { rede patien- } \\
\text { ter med } \\
\text { skizofreni, } \\
\text { som har haft } \\
\text { kontakt med } \\
\text { sekundær } \\
\text { sektor pr. } \\
100.000 \\
\text { indbyggere } \\
\text { pr. år (45- } \\
64)\end{array}$ & $\begin{array}{r}\text { Antal } \\
\text { diagnostice- } \\
\text { rede patien- } \\
\text { ter med } \\
\text { skizofreni, } \\
\text { som har haft } \\
\text { kontakt med } \\
\text { sekundær } \\
\text { sektor pr. } \\
100.000 \\
\text { indbyggere } \\
\text { pr. år (65- } \\
84)\end{array}$ & $\begin{array}{r}\text { Antal } \\
\text { diagnostice- } \\
\text { rede patien- } \\
\text { ter med } \\
\text { skizofreni, } \\
\text { som har haft } \\
\text { kontakt med } \\
\text { sekundær } \\
\text { sektor pr. } \\
100.000 \\
\text { indbyggere } \\
\text { pr. år }(85+)\end{array}$ \\
\hline Danmark & 129,8 & 206,6 & 163,7 & 128,1 & 52,7 & 21,1 \\
\hline Finland & 177,3 & 93,2 & 252,3 & 290,7 & 133,0 & 13,6 \\
\hline Færøerne & 70,6 & 30,4 & 76,3 & 159,9 & 53,0 & 180,8 \\
\hline Grønland & N/A & $N / A$ & N/A & N/A & N/A & N/A \\
\hline Island & N/A & N/A & N/A & N/A & N/A & N/A \\
\hline Norge & 110,6 & 85,6 & 133,2 & 134,3 & 59,7 & 13,2 \\
\hline Sverige & 131,0 & 28,3 & 113,9 & 205,8 & 120,2 & 24,2 \\
\hline
\end{tabular}

Anm.: For Finland og Færøerne er der anvendt hele befolkningen. $\varnothing$ vrige lande har anvendt 18+ befolkning. Endvidere er aldersgruppen 18-24 år erstattet af 15-24 år for Finland. For Færøerne er tallene baseret på et gennemsnit for 2005-2009. Resultater fra Norge er overestimeret jf. indledende kommentarer.

Bemærkninger: tabel 2.2.5, tabel 2.2.6 og tabel 2.2.7:

Tallene fra Færøerne er ikke sammenlignelige med de øvrige fire lande pga. det lille datagrundlag jf. de indledende kommentarer. Resultatet for $18+$ befolkningen er ikke sammenlignelig med Finland. Finland har anvendt aldersgruppen 15-24 år, øvrige lande 18-24 år, hvorfor Finlands tal ikke er sammenligneligt med $\emptyset$ vrige landes. Generelt set for alle lande med undtagelse af Sverige topper antallet af diagnosticerede patienter med skizofreni (samlet) i aldersgruppen 25-44 år. Resultaterne for Danmark, Norge og Sverige er ikke signifikant forskellige for den samlede voksenbefolkning med hhv. 166,5, 159,3 og 169,3 pr. 100.000 indbyggere.

Danmark har flest diagnosticeret patienter med skizofreni i den unge aldersgruppe (18-24 år) med 229,2 pr. 100.000 indbyggere, hvor Sverige har færrest med 44,5 pr. 100.000 indbyggere. I mellemgrupperne (25-44 år og 45-64 år) hvor Finlands tal er sammenlignelige med de tre øvrige landes - har Finland flere end de øvrige med hhv. 356,4 og 305,1 pr. 100.000 indbyggere. Sverige har færrest i den yngste mellemgruppe (25-44 år) med 171,1 pr. 100.000 indbyggere, mens Danmark har færrest i den ældste mellemgruppe (45-64 år) med 156,5 pr. 100.000 indbyggere. I aldersgruppen 65-84 har Finland flest med 119,7 pr. 100.000 indbyggere, mens Sverige har 109,8 pr. 100.000 indbyggere. Danmark og Norge har ca. halvt så mange som de $\varnothing$ vrige lande med hhv. 45,9 og 58,2 pr. 100.000 indbyggere. I den ældste aldersgruppe (85+) har Sverige flest med 21,1 pr. 100.000 indbygger, mens Finland har færrest med 11,9 pr. 100.000 indbyggere.

Generelt for de fire lande er de diagnosticerede skizofrenipatienter i Danmark i større omfang at finde i de lavere aldersgrupper, mens der i Sverige er en klart større tendens til, at de diagnosticerede skizofrenipatienter er at finde i de ældre aldersgrupper. I Finland og Norge tegner sig det samme billede, hvor der er få diagnosticerede patienter med skizofreni i den yngre aldersgruppe, hvorefter kurven topper i aldersgruppen 25-44 for derefter gradvist at aftage. Generelt er billedet det samme opdelt på køn, men der er færre diagnosticerede kvinder med skizofreni end mænde i alle landene. Tallene for Færøerne er baseret på indlagte patienter. 
Tabel 2.2.8. Diagnosticerede patienter med skizofreni og misbrugsdiagnose 2009 (Samlet) - basisindikatorer

\begin{tabular}{|c|c|c|c|c|c|c|}
\hline Land & $\begin{array}{r}\text { Antal } \\
\text { diagnostice- } \\
\text { rede patien- } \\
\text { ter med } \\
\text { skizofreni og } \\
\text { misbrugsdi- } \\
\text { agnose, som } \\
\text { har haft } \\
\text { kontakt med } \\
\text { sekundær } \\
\text { sektor pr. } \\
100.000 \\
\text { indbyggere } \\
\text { pr. år (18+) }\end{array}$ & $\begin{array}{r}\text { Antal } \\
\text { diagnostice- } \\
\text { rede patien- } \\
\text { ter med } \\
\text { skizofreni og } \\
\text { misbrugsdi- } \\
\text { agnose, som } \\
\text { har haft } \\
\text { kontakt med } \\
\text { sekundær } \\
\text { sektor pr. } \\
100.000 \\
\text { indbyggere } \\
\text { pr. år (18- } \\
24)\end{array}$ & $\begin{array}{r}\text { Antal } \\
\text { diagnostice- } \\
\text { rede patien- } \\
\text { ter med } \\
\text { skizofreni og } \\
\text { misbrugsdi- } \\
\text { agnose, som } \\
\text { har haft } \\
\text { kontakt med } \\
\text { sekundær } \\
\text { sektor pr. } \\
100.000 \\
\text { indbyggere } \\
\text { pr. år (25- } \\
44)\end{array}$ & $\begin{array}{r}\text { Antal } \\
\text { diagnostice- } \\
\text { rede patien- } \\
\text { ter med } \\
\text { skizofreni og } \\
\text { misbrugsdi- } \\
\text { agnose, som } \\
\text { har haft } \\
\text { kontakt med } \\
\text { sekundær } \\
\text { sektor pr. } \\
100.000 \\
\text { indbyggere } \\
\text { pr. år (45- } \\
64)\end{array}$ & $\begin{array}{r}\text { Antal } \\
\text { diagnostice- } \\
\text { rede patien- } \\
\text { ter med } \\
\text { skizofreni og } \\
\text { misbrugsdi- } \\
\text { agnose, som } \\
\text { har haft } \\
\text { kontakt med } \\
\text { sekundær } \\
\text { sektor pr. } \\
100.000 \\
\text { indbyggere } \\
\text { pr. år (65- } \\
84)\end{array}$ & $\begin{array}{r}\text { Antal } \\
\text { diagnostice- } \\
\text { rede patien- } \\
\text { ter med } \\
\text { skizofreni og } \\
\text { misbrugsdi- } \\
\text { agnose, som } \\
\text { har haft } \\
\text { kontakt med } \\
\text { sekundær } \\
\text { sektor pr. } \\
100.000 \\
\text { indbyggere } \\
\text { pr. år }(85+)\end{array}$ \\
\hline Danmark & 35,5 & 41,4 & 55,8 & 33,5 & 2,4 & 0,0 \\
\hline Finland & 4,9 & 2,7 & 10,6 & 6,1 & 1,0 & 0,0 \\
\hline Færøerne & N/A & N/A & $\mathrm{N} / \mathrm{A}$ & N/A & N/A & N/A \\
\hline Grønland & N/A & N/A & N/A & N/A & N/A & N/A \\
\hline Island & N/A & $\mathrm{N} / \mathrm{A}$ & N/A & N/A & N/A & N/A \\
\hline Norge & 14,0 & 10,9 & 26,8 & 9,0 & 0,2 & 0,0 \\
\hline Sverige & 8,6 & 3,7 & 11,4 & 12,5 & 1,4 & 0,0 \\
\hline
\end{tabular}

Anm.: For Finland er der anvendt hele befolkningen. $\varnothing$ vrige lande har anvendt $18+$ befolkning. Endvidere er aldersgruppen 18-24 år erstattet af 15-24 år for Finland. Resultater fra Norge er overestimeret jf. indledende kommentarer.

Tabel 2.2.9. Diagnosticerede patienter med skizofreni 2009 og misbrugsdiagnose (Mænd) - basisindikatorer

\begin{tabular}{|c|c|c|c|c|c|c|}
\hline Land & $\begin{array}{r}\text { Antal } \\
\text { diagnostice- } \\
\text { rede patien- } \\
\text { ter med } \\
\text { skizofreni og } \\
\text { misbrugsdi- } \\
\text { agnose, som } \\
\text { har haft } \\
\text { kontakt med } \\
\text { sekundær } \\
\text { sektor pr. } \\
100.000 \\
\text { indbyggere } \\
\text { pr. år }(18+)\end{array}$ & $\begin{array}{r}\text { Antal } \\
\text { diagnostice- } \\
\text { rede patien- } \\
\text { ter med } \\
\text { skizofreni og } \\
\text { misbrugsdi- } \\
\text { agnose, som } \\
\text { har haft } \\
\text { kontakt med } \\
\text { sekundær } \\
\text { sektor pr. } \\
100.000 \\
\text { indbyggere } \\
\text { pr. år (18- } \\
24)\end{array}$ & $\begin{array}{r}\text { Antal } \\
\text { diagnostice- } \\
\text { rede patien- } \\
\text { ter med } \\
\text { skizofreni og } \\
\text { misbrugsdi- } \\
\text { agnose, som } \\
\text { har haft } \\
\text { kontakt med } \\
\text { sekundær } \\
\text { sektor pr. } \\
100.000 \\
\text { indbyggere } \\
\text { pr. år (25- } \\
44)\end{array}$ & $\begin{array}{r}\text { Antal } \\
\text { diagnostice- } \\
\text { rede patien- } \\
\text { ter med } \\
\text { skizofreni og } \\
\text { misbrugsdi- } \\
\text { agnose, som } \\
\text { har haft } \\
\text { kontakt med } \\
\text { sekundær } \\
\text { sektor pr. } \\
100.000 \\
\text { indbyggere } \\
\text { pr. år (45- } \\
64)\end{array}$ & $\begin{array}{r}\text { Antal } \\
\text { diagnostice- } \\
\text { rede patien- } \\
\text { ter med } \\
\text { skizofreni og } \\
\text { misbrugsdi- } \\
\text { agnose, som } \\
\text { har haft } \\
\text { kontakt med } \\
\text { sekundær } \\
\text { sektor pr. } \\
100.000 \\
\text { indbyggere } \\
\text { pr. år (65- } \\
84)\end{array}$ & $\begin{array}{r}\text { Antal } \\
\text { diagnostice- } \\
\text { rede patien- } \\
\text { ter med } \\
\text { skizofreni og } \\
\text { misbrugsdi- } \\
\text { agnose, som } \\
\text { har haft } \\
\text { kontakt med } \\
\text { sekundær } \\
\text { sektor pr. } \\
100.000 \\
\text { indbyggere } \\
\text { pr. år }(85+)\end{array}$ \\
\hline Danmark & 57,5 & 62,9 & 93,5 & 49,0 & 2,2 & 0,0 \\
\hline Finland & 8,3 & 4,5 & 17,8 & 9,9 & 1,4 & 0,0 \\
\hline Færøerne & N/A & N/A & $\mathrm{N} / \mathrm{A}$ & N/A & N/A & N/A \\
\hline Grønland & $\mathrm{N} / \mathrm{A}$ & N/A & $\mathrm{N} / \mathrm{A}$ & N/A & N/A & N/A \\
\hline Island & $\mathrm{N} / \mathrm{A}$ & N/A & $\mathrm{N} / \mathrm{A}$ & N/A & $\mathrm{N} / \mathrm{A}$ & N/A \\
\hline Norge & 23,1 & 19,0 & 42,9 & 13,8 & 0,0 & 0,0 \\
\hline Sverige & 14,5 & 6,2 & 19,6 & 19,7 & 2,3 & 0,0 \\
\hline
\end{tabular}

Anm.: For Finland er der anvendt hele befolkningen. $\varnothing$ vrige lande har anvendt $18+$ befolkning.. Endvidere er aldersgruppen 18-24 år erstattet af 15-24 år for Finland. Resultater fra Norge er overestimeret jf. indledende kommentarer. 
Tabel 2.2.10. Diagnosticerede patienter med skizofreni og misbrugsdiagnose 2009 (Kvinder) basisindikatorer

\begin{tabular}{|c|c|c|c|c|c|c|}
\hline Land & $\begin{array}{r}\text { Antal diagno- } \\
\text { sticerede } \\
\text { patienter med } \\
\text { skizofreni og } \\
\text { misbrugsdiag- } \\
\text { nose, som har } \\
\text { haft kontakt } \\
\text { med sekundær } \\
\text { sektor pr. } \\
100.000 \\
\text { indbyggere pr. } \\
\text { år (18+) }\end{array}$ & $\begin{array}{r}\text { Antal diagno- } \\
\text { sticerede } \\
\text { patienter med } \\
\text { skizofreni og } \\
\text { misbrugsdiag- } \\
\text { nose, som har } \\
\text { haft kontakt } \\
\text { med sekundær } \\
\text { sektor pr. } \\
100.000 \\
\text { indbyggere pr. } \\
\text { år (18-24) }\end{array}$ & $\begin{array}{r}\text { Antal diagno- } \\
\text { sticerede } \\
\text { patienter med } \\
\text { skizofreni og } \\
\text { misbrugsdiag- } \\
\text { nose, som har } \\
\text { haft kontakt } \\
\text { med sekundær } \\
\text { sektor pr. } \\
100.000 \\
\text { indbyggere pr. } \\
\text { år (25-44) }\end{array}$ & $\begin{array}{r}\text { Antal diagno- } \\
\text { sticerede } \\
\text { patienter med } \\
\text { skizofreni og } \\
\text { misbrugsdiag- } \\
\text { nose, som har } \\
\text { haft kontakt } \\
\text { med sekundær } \\
\text { sektor pr. } \\
100.000 \\
\text { indbyggere pr. } \\
\text { år (45-64) }\end{array}$ & $\begin{array}{r}\text { Antal diagno- } \\
\text { sticerede } \\
\text { patienter med } \\
\text { skizofreni og } \\
\text { misbrugsdiag- } \\
\text { nose, som har } \\
\text { haft kontakt } \\
\text { med sekundær } \\
\text { sektor pr. } \\
100.000 \\
\text { indbyggere pr. } \\
\text { år (65-84) }\end{array}$ & $\begin{array}{r}\text { Antal diagno- } \\
\text { sticerede } \\
\text { patienter med } \\
\text { skizofreni og } \\
\text { misbrugsdiag- } \\
\text { nose, som har } \\
\text { haft kontakt } \\
\text { med sekundær } \\
\text { sektor pr. } \\
100.000 \\
\text { indbyggere pr. } \\
\text { år }(85+)\end{array}$ \\
\hline Danmark & 14,3 & 18,9 & 17,5 & 17,9 & 2,6 & 0,0 \\
\hline Finland & 1,6 & 0,9 & 3,0 & 2,3 & 0,7 & 0,0 \\
\hline Færøerne & $\mathrm{N} / \mathrm{A}$ & N/A & $\mathrm{N} / \mathrm{A}$ & N/A & N/A & N/A \\
\hline Grønland & $\mathrm{N} / \mathrm{A}$ & N/A & $\mathrm{N} / \mathrm{A}$ & N/A & N/A & N/A \\
\hline Island & $\mathrm{N} / \mathrm{A}$ & N/A & N/A & N/A & N/A & N/A \\
\hline Norge & 5,5 & 2,4 & 9,9 & 4,0 & 0,3 & 0,0 \\
\hline Sverige & 2,9 & 1,2 & 2,9 & 5,2 & 0,7 & 0,0 \\
\hline
\end{tabular}

Anm.: For Finland er der anvendt hele befolkningen. $\emptyset$ vrige lande har anvendt $18+$ befolkning. Endvidere er aldersgruppen 18-24 år erstattet af 15-24 år for Finland. Resultater fra Norge er overestimeret jf. indledende kommentarer.

Bemærkninger til tabel 2.2.8, tabel 2.2.9 og tabel 2.2.10:

Resultat for $18+$ befolkningen fra Finland er ikke sammenlignelig med de $\varnothing$ vrige tre landes, da Finland har anvendt hele befolkningen som grundlag. Finland har anvendt aldersgruppen 15-24 år i stedet for 18-24 år, hvorfor dette resultat ikke er sammenligneligt med de $\varnothing$ vrige landes. Danmark har signifikant flere diagnosticerede patienter med skizofren og misbrugsdiagnose end de øvrige lande. I Danmark er der således 35,5 pr. 100.000 indbyggere, mens der for Norge og Sverige er hhv. 14,0 og 8,6 pr. 100.000 indbyggere. Aldersfordelingen på tværs af landene viser samme tendens, med klart flest i Danmark i alle aldersgrupperne. For alle landene med undtagelse af Sverige er der flest i aldersgruppen 25-44 år, mens Sverige har lidt flere i aldersgruppen 45-64 år.

Norge har flere diagnosticerede patienter med skizofreni og misbrugsdiagnose end Sverige i de yngre aldersgrupper (18-24 år og 25-44 år), mens Sverige har flere end Norge i de ældre aldersgrupper (45-64 år og 65-84 år). Generelt har samtlige lande flere mænd, der er diagnosticeret med skizofreni og misbrugsdiagnose end kvinder.

Tabel 2.2.11. Dødelighed for patienter med skizofreni 2009 - basisindikatorer

\begin{tabular}{lrrr}
\hline Land & $\begin{array}{r}\text { Andel självmord inom ett år för patienter med kon- } \\
\text { takt med psykiatrin for schizofreni. Samtliga patienter } \\
\text { som vårdats inom specialiserad psykiatrisk vård (som } \\
\text { inlagd eller med läkarbesök i öppen vård) under ett } \\
\text { kalenderår (räknat från första besöksdatum för året } \\
\text { eller första inläggningsdagen vid första inskrivningen) }\end{array}$ & $\begin{array}{r}\text { Antallet af dødsfald pr. } \\
\mathbf{1 0 . 0 0 0 ~ i n d b y g e r e ~ m e d ~} \\
\text { skizofreni der på et eller } \\
\text { andet tidspunkt indenfor de } \\
\text { sidste } \mathbf{5} \text { år er blevet behand- } \\
\text { let for skizofreni (20-59 år) }\end{array}$ & $\begin{array}{r}\text { Antallet af } \\
\text { dødsfald i } \\
\text { befolkningen } \\
\text { pr. 10.000 } \\
\text { indbyggere } \\
\text { (20-59 år) }\end{array}$ \\
\hline Danmark & $0,19 \%$ & 90,5 & 23,6 \\
Finland & $0,16 \%$ & 480,8 & 24,5 \\
Færøerne & N/A & 0,0 & 17,3 \\
Grønland & N/A & N/A & N/A \\
Island & N/A & N/A & N/A \\
Norge & N/A & N/A & N/A \\
Sverige & 0,29\% & 99,4 & 15,3 \\
\hline
\end{tabular}

Anm.: For selvmord gælder, at selvmordet er sket i 2009, men patienten kan senest have haft kontakt med psykiatrisk afdeling i 2008.

Bemærkninger: Ud fra tallene for selvmord for skizofrenipatienter kan det konkluderes, at der er relativt flere skizofrenipatienter, der begår selvmord i Sverige i forhold til Danmark og Finland. I Sverige er det 0,29 pct. af skizofrenipatienterne der indenfor et år efter kontakt med psykiatrisk afdeling har begået selvmord, mens tallene for Danmark og Finland hhv. er 0,19 pct. og 0,16 pct.

Ved dødsfald for patienter behandlet for skizofreni indenfor 5 år (20-59 år) er tal for Færøerne ikke sammenlignelige med de $\emptyset$ vrige landes pga. det begrænsede datagrundlag jf. de indledende kommentarer. Resultaterne for Danmark og Sverige viser, at der relativt er flere dødsfald hos skizofrenipatienter i Sverige end i Danmark. Endvidere kan det konkluderes, for befolkningen som helhed (20-59 år), at der dør færre pr. 10.000 indbyggere i Sverige end i Danmark og Finland. Tallene for Færøerne er baseret på indlagte patienter. 
Tabel 2.2.12. Genindlæggelser for skizofreni - kvalitetsindikatorer

\begin{tabular}{|c|c|c|c|}
\hline Land & $\begin{array}{r}\text { Genindlæggelse på psykia- } \\
\text { trisk afdeling for skizofreni } \\
\text { (14 til } 28 \text { dage) }\end{array}$ & $\begin{array}{l}\text { Genindlæggelse på psykia- } \\
\text { trisk afdeling for skizofreni } \\
\text { ( } 3 \text { til } 6 \text { måneder) }\end{array}$ & $\begin{array}{r}\text { Uplanlagt skizofreni (samme } \\
\text { hospital) genindlæggelsesra- } \\
\text { te (2007) }\end{array}$ \\
\hline Danmark & $8,9 \%$ & $11,3 \%$ & $23,2 \%$ \\
\hline Finland & $2,4 \%$ & $23,0 \%$ & $31,9 \%$ \\
\hline Færøerne & $7,0 \%$ & $19,0 \%$ & N/A \\
\hline Grønland & $3,7 \%$ & $14,8 \%$ & N/A \\
\hline Island & N/A & N/A & N/A \\
\hline Norge & $8,0 \%$ & $5,1 \%$ & $22,6 \%$ \\
\hline Sverige & $\mathrm{N} / \mathrm{A}$ & N/A & $27,0 \%$ \\
\hline
\end{tabular}

Anm.: For Færøerne er tallene baseret på et gennemsnit for 2005-2009.

Bemærkninger: Data fra Færøerne og Grønland er ikke sammenlignelige med de øvrige landes pga. det begrænsede datagrundlag. Ved genindlæggelser på psykiatrisk afdeling for skizofreni mellem 14 til 28 dage er der relativt flere i Danmark med 8,9 pct. i forhold til Norge med 8,0 pct. og Finland med 2,4 pct. Vedrørende genindlæggelser mellem 3 og 6 måneder er der relativt flere i Finland med 23,0 pct. i forhold til Danmark med 11,3 pct. og Norge med 5,1 pct. Tabellen viser desuden, at der er relativt flest uplanlagte genindlæggelser til samme sygehus i Finland med en andel på 31,9 pct., mens der er relativt færrest i Norge med 22,6 pct. Tallene for Færøerne er baseret på indlagte patienter.

Tabel 2.2.13. Data fra Det Nationale Indikatorprojekt i Danmark for Skizofreni 2010 - kvalitetsindikatorer

2004

Andelen af incidente patienter med skizofreni, der udredes for psykopatologi $94(92 ; 96) \quad 94(93 ; 96)$ ved speciallæge

Andelen af incidente patienter med skizofreni, der udredes for psykopatologi og interviewes med diagnostisk instrument (SAN, PSE, OPCRIT, SCID)

Andelen af incidente patienter med skizofreni, der udredes for kognitiv funktion ved psykolog

Andelen af incidente patienter med skizofreni, der udredes for sociale støttebehov ved socialrådgiver

Andelen af incidente patienter med skizofreni, der udredes for varighed af ubehandlet psykose og som er i behandling indenfor 6 måneder efter symptomdebut

Andelen af ambulante patienter med skizofreni, som har tilknyttet et fast medlem af behandlerteamet og/eller har fået iværksat et psykoterapeutisk behandlingsforløb Andelen af patienter med skizofreni, som får ordineret antipsykotisk behandling Andelen af ambulante patienter med skizofreni, som får mere end ét antipsykotikum ved årsstatus

Andelen af ambulante patienter med skizofreni, som får benzodiazepiner eksklusi benzodiazepinlignende midler (zolpidem, zopiclon, zaleplon) ved årsstatus Andelen af indlagte patienter med skizofreni, der får vurderet selvmordsrisiko, dokumenteret $\mathrm{i}$ journalen, ved udskrivelsen

Andelen af patienter med skizofreni, der modtager psykiatrisk efterbehandling ved udskrivelsen

Andel af indlagte og ambulante patienter med skizofreni og pårørende, der får tilbudt $33(12 ; 62) \quad 70(67 ; 73)$

$27(23 ; 32) \quad 48(45 ; 51)$

$82(78 ; 85) \quad 86(84 ; 89)$

$34(30 ; 39) \quad 35(32 ; 39)$

$83(72 ; 91) \quad 97(97 ; 98)$

$95(94 ; 95) \quad 94(94 ; 95)$ $35(34 ; 37)$ psykoedukativ familieintervention

Andelen af patienter med skizofreni, som har neurologiske bivirkninger

Andelen af patienter med skizofreni, som har søvn- og sedationsbivirkninger

Andelen af patienter med skizofreni, som har haft vægtøgnin

Andelen af patienter med skizofreni, som har seksuelle bivirkninger

Andelen af patienter med skizofreni, som har forhøjet BMI

Andelen af patienter med skizofreni, som har forøget taljeomfang

Andelen af patienter med skizofreni, som har forhøjet blodsukker

Andelen af patienter med skizofreni, som har dyslipidæmi

$61(60 ; 62)$

Andelen af patienter med skizofreni, som har forhøjet blodtryk

\section{Anm.: Alle resultater er angivet i procent.}

Bemærkninger: Tabel 2.2.13. illustrerer resultater fra Det Nationale Indikatorprojekt (NIP) i Danmark, som blev etableret i 2000. NIP monitorerer kvaliteten af behandlingen af patienter med skizofreni i Danmark. Der er obligatorisk deltagelse for alle danske hospitaler, der behandler patienter med skizofreni, De respektive hospitalsafd elinger skal således sende data til NIP for alle patienter de behandler med skizofreni. Kvalitetsindikatorerne, der indgår i NIP afspejler det nationale referenceprogram for skizofreni i Danmark. Tabellen viser resultater fra 2004, hvor de første resultater blev offentliggjort fra projektet og fra 2010. Tabellen viser, at der i denne tidsperiode er sket en stigning i antallet af patienter med skizofreni, der får de interventioner, som de skal have ifølge det nationale referenceprogram. 


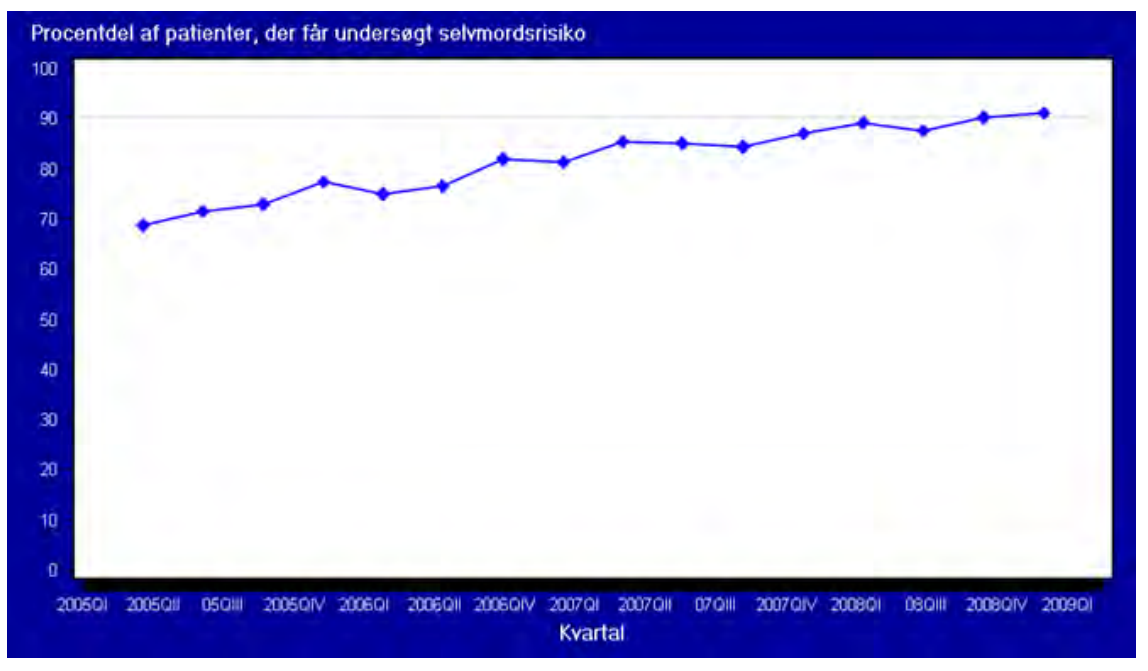

Figur 2.1: Eksempel på procentdel af patienter, der får undersøgt selvmordsrisiko Kilde: Det Nationale Indikatorprojekt NIP.

Bemærkninger: Figur 2.1 viser andelen af voksne patienter med skizofreni, hvor der er dokumentation for, at patienterne blev undersøgt for selvmordsrisiko i perioden fra 2005 til 2009. Det fremgår, at andelen i denne tidsperiode var stigende.

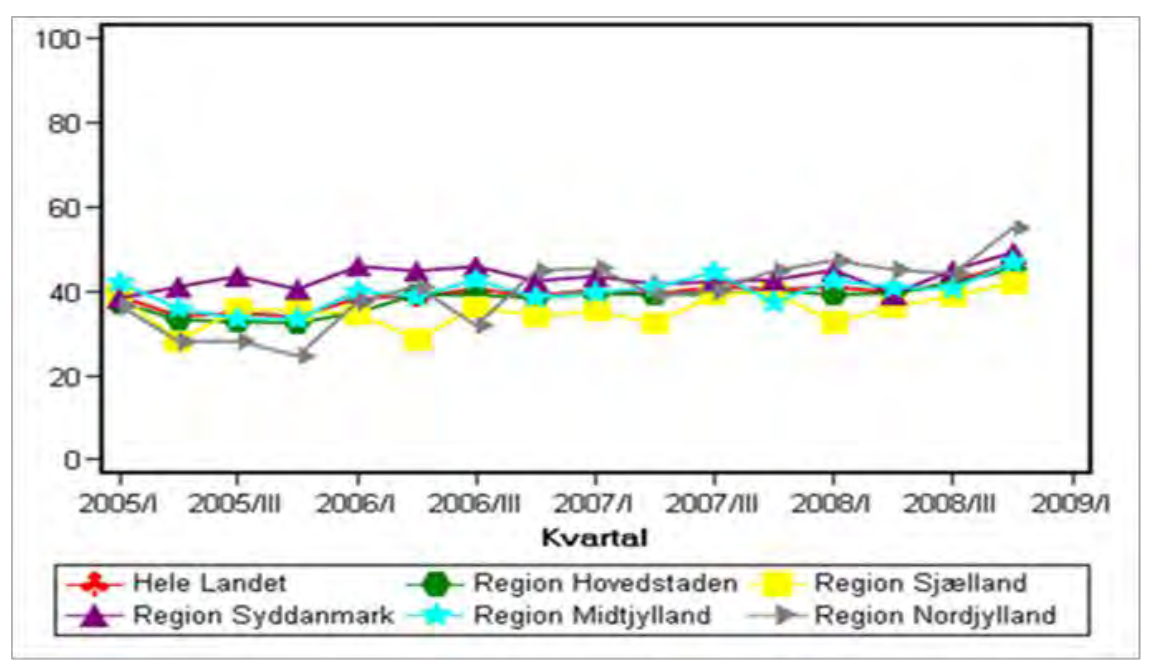

Figur 2.2: Andelen af patienter med skizofreni der i de fem danske regioner har modtaget alle anbefalede interventioner i perioden 2005-2008 (all-or-none)

Kilde: Det Nationale Indikatorprojekt NIP

Bemærkninger: Figur 2.2 viser andelen af patienter med skizofreni i de fem danske regioner, der i perioden 2005 2008 har modtaget alle anbefalede interventioner, udvalgt på grundlag af det danske referenceprogram for skizofreni. Denne opgørelsesmåde betegnes all-or-none, Indikatoren er en såkaldt sammensat indikator (composite measure). Det fremgår, at andelen har været stigende i denne tidsperiode. 
Tabel 2.2.14. Varighed av ubehandlet psykose (VUP (i antall uker ved første episode ikke affektiv psykose)) - kvalitetsindikatorer

\begin{tabular}{lr}
\hline & Norge \\
\hline Gjennomsnittlig varighet ubehandlet psykose & 67,6 uker \\
Median varighet ubehandlet psykose & 9,7 uker
\end{tabular}

Anm.: Gjennomsnittlig varighet ubehandlet psykose: Data dekker ca 2/3-del av antatt populasjon.

Bemærkninger: Varighet av ubehandlet psykose (VUP) reflekterer tidsrommet fra sykdom oppstår til adekvat behandling gis. En slik forsinkelse av behandling kan oppstå på flere nivåer: hos pasienten selv, familien, primærhelsetjenesten og spesialisthelsetjenesten. Denne forsinkelsen vil oftest være korrelert med langtidsforløpet. Lang VUP innebærer $\varnothing k t$ lidelse for pasienten og dennes familie, og påvirker prognosen. Det er en målsetning å redusere VUP mest mulig, og tjenestene innen psykisk helse i Norge rapporterer derfor på dette som en kvalitetsindikator. Det har vært en utfordring å få inn gode tall på denne indikatoren, men de tallene man har, viser en svært lang gjennomsnittlig varighet av ubehandlet psykose. Dette gjenspeiler at noen pasienter går svært lenge før de får adekvat behandling. Mediantallene er imidlertid betydelig lavere og gir en bedre beskrivelse av hvorvidt man lykkes med å gi pasienten behandling tidlig i forløpet.

Tabel 2.2.15 Undvikbara somatisk slutenvårdstillfällen och återinskrivning efter sluten psykiatrisk vård för schizofreni - kvalitetsindikatorer

Undvikbar somatisk slutenvård efter vård för schizofreni inom psykiatrin per 100.000 invå-

1114 dagar nare (Män)

Undvikbar somatisk slutenvård efter vård för schizofreni inom psykiatrin per 100.000 invånare (Kvinnor)

Återinskrivning inom 14 dagar efter sluten vård för schizofreni

Återinskrivning inom 28 dagar efter sluten vård för schizofreni

1578 dagar

Återinskrivning inom 3 månader

Återinskrivning inom 6 månader

(2)

Anm: Data för undvikbara somatiska slutenvårdstillfällen efter vård inom psykiatrin är för 2008 och patienter mellan 20-59 år.

Bemærkninger: Indikatorn undvikbar somatisk slutenvård ska belysa omhändertagandet vid vissa speicificerade sjukdomstillstånd inom den öppna vården, till exempel genom en fungerande primärvård och förebyggande folkhälsoarbete. Som undvikbar slutenvård räknas till exempel vård för diagnoserna astma, diabetes, hjärtsvikt och KOL. En jämförelse görs också med en population utan tidigare psykiatrisk vård. Tanken är att man kan förhindra onödiga inläggningar på sjukhus om patienter får ett bra omhändertagande $i$ den öppna somatiska vården. För mera information om indikatorn hänvisas till rapport http://www.socialstyrelsen.se/Lists/Artikelkatalog/Attachments/18050/2010-6-6.pdf 


\subsection{Skizofreni - børn og unge}

Tabel 2.3.1. Diagnosticerede patienter med skizofreni og selvmord 2009 (børne- og ungdomsskizofreni) - basisindikatorer

\begin{tabular}{|c|c|c|}
\hline Land & $\begin{array}{r}\text { Antal diagnosticerede patien- } \\
\text { ter med skizofreni, som har } \\
\text { haft kontakt med sekundær } \\
\text { sektor pr. } 100.000 \text { indbyggere } \\
\text { pr. år (0-17) }\end{array}$ & $\begin{array}{l}\text { Andel självmord inom ett år för patienter med kontakt med } \\
\text { psykiatrin for schizofreni. Samtliga patienter som vårdats inom } \\
\text { specialiserad psykiatrisk vård (som inlagd eller med läkarbesök i } \\
\text { öppen vård) under ett kalenderår (räknat från första besöksdatum } \\
\text { för året eller första inläggningsdagen vid första inskrivningen). }\end{array}$ \\
\hline Danmark & 25,3 & $0,0 \%$ \\
\hline Finland & 210,9 & $0,0 \%$ \\
\hline Færøerne & 13,6 & $0,0 \%$ \\
\hline Grønland & N/A & $\mathrm{N} / \mathrm{A}$ \\
\hline Island & N/A & N/A \\
\hline Norge & 3,5 & N/A \\
\hline Sverige & 7,4 & $0,0 \%$ \\
\hline
\end{tabular}

Anm.: For Finland er antal diagnosticerede patienter ikke kun for børne- og ungdomsskizofreni, men alle skizofrenipatienter. For Færøerne er tallene baseret på et gennemsnit for 2005-2009. Resultat fra Norge er overestimeret jf. indledende kommentarer.

Bemærkninger: Data for Finland er ikke sammenlignelig med de andre landes resultater, da resultatet gælder diagnosticerede patienter med skizofreni for hele befolkningen. På grund af det begrænsede datagrundlag for Færøerne er deres resultat ikke sammenlignelig med de andre landes. Danmark har med 25,3 pr. 100.000 indbyggere flere diagnosticerede børn- og unge med skizofreni end Sverige og Norge med hhv. 7,4 og 3,5 pr. 100.000 indbyggere. Ingen børn og unge med skizofreni har begået selvmord indenfor 1 år efter kontakt. Tallene for Færøerne er baseret på indlagte patienter. 
Tabel 2.3.2. Data fra Det Nationale Indikatorprojekt i Danmark for Skizofreni 2010 for børn og unge - kvalitetsindikatorer

\begin{tabular}{|c|c|}
\hline & Danmark \\
\hline Andelen af incidente patienter med skizofreni, der udredes for psykopatologi ved speciallæge & $97(90 ; 100)$ \\
\hline $\begin{array}{l}\text { Andelen af incidente patienter med skizofreni, der udredes for psykopatologi og interviewes med } \\
\text { diagnostisk instrument (SAN, PSE, OPCRIT, SCID) }\end{array}$ & $87(76 ; 94)$ \\
\hline Andelen af incidente patienter med skizofreni, der udredes for kognitiv funktion ved psykolog & $91(82 ; 97)$ \\
\hline Andelen af incidente patienter med skizofreni, der udredes for sociale støttebehov ved socialrådgiver & $95(87 ; 99)$ \\
\hline $\begin{array}{l}\text { Andelen af incidente patienter med skizofreni, der udredes for varighed af ubehandlet psykose og } \\
\text { som er i behandling indenfor } 6 \text { måneder efter symptomdebut }\end{array}$ & $63(50 ; 75)$ \\
\hline $\begin{array}{l}\text { Andelen af ambulante patienter med skizofreni, som har tilknyttet et fast medlem af behandlertea- } \\
\text { met og/eller har fået iværksat et psykoterapeutisk behandlingsforløb }\end{array}$ & $99(95 ; 100)$ \\
\hline Andelen af patienter med skizofreni, hvor pårørende tager imod tilbudet om kontakt & $97(93 ; 99)$ \\
\hline $\begin{array}{l}\text { Andelen af incidente patienter med skizofreni, der indenfor } 1 \text { år, modtager psykoedukation i manua- } \\
\text { liserede forløb }\end{array}$ & $34(23 ; 47)$ \\
\hline $\begin{array}{l}\text { Andelen af indlagte patienter med skizofreni, der får vurderet selvmordsrisiko, dokumenteret i } \\
\text { journalen, ved udskrivelsen }\end{array}$ & $92(84 ; 97)$ \\
\hline Andelen af patienter med skizofreni, som får ordineret antipsykotisk behandling & $96(93 ; 99)$ \\
\hline Andelen af ambulante patienter med skizofreni, som får mere end ét antipsykotikum ved årsstatus & $16(6 ; 32)$ \\
\hline $\begin{array}{l}\text { Andelen af ambulante patienter med skizofreni, som får benzodiazepiner eksklusiv benzodiazepin- } \\
\text { lignende midler (zolpidem, zopiclon, zaleplon) ved årsstatus }\end{array}$ & $6(1 ; 21)$ \\
\hline $\begin{array}{l}\text { Andelen af patienter med skizofreni, med GAPD funktionsscore }>=5 \text { ved udskrivelse og som udskri- } \\
\text { ves med social støtteforanstaltning } \mathrm{i} \text { bolig }\end{array}$ & $95(84 ; 99)$ \\
\hline Andelen af patienter med skizofreni, der modtager psykiatrisk efterbehandling ved udskrivelsen & $85(75 ; 91)$ \\
\hline $\begin{array}{l}\text { Andelen af patienter med skizofreni, der indenfor } 1 \frac{1}{2} \text { år efter udskrivelsen har fået udfyldt et } \\
\text { statusskema for ambulante patienter }\end{array}$ & $79(65 ; 90)$ \\
\hline Andelen af patienter med skizofreni, som har neurologiske bivirkninger & $23(15 ; 31)$ \\
\hline Andelen af patienter med skizofreni, som har søvn- og sedationsbivirkninger & $32(24 ; 41)$ \\
\hline Andelen af patienter med skizofreni, som har haft vægtøgning & $40(30 ; 49)$ \\
\hline Andelen af patienter med skizofreni, som har seksuelle bivirkninger & $4(1 ; 12)$ \\
\hline Andelen af patienter med skizofreni, som har forhøjet BMI & $16(8: 26)$ \\
\hline Andelen af patienter med skizofreni, som har forhøjet blodsukker & $5(1 ; 12)$ \\
\hline Andelen af patienter med skizofreni, som har dyslipidæmi & $51(39: 62)$ \\
\hline Andelen af patienter med skizofreni, som har forh øjet blodtryk & $24(15 ; 35)$ \\
\hline
\end{tabular}

Anm.: Alle resultater er angivet i procent. Resultaterne er baseret på meget få patientforløb (under 200)

Bemærkninger: Tabel 2.3.2. illustrerer resultater fra Det Nationale Indikatorprojekt (NIP) i Danmark, som blev etableret i 2000. NIP monitorerer kvaliteten af behandlingen af patienter med skizofreni i Danmark. Der er obligatorisk deltagelse for alle danske hospitaler, der behandler patienter med skizofreni, De respektive hospitalsafdelinger skal således sende data til NIP for alle patienter de behandler med skizofreni. Kvalitetsindikatorerne, der indgår i NIP afspejler det nationale referenceprogram for skizofreni i Danmark. Tabellen viser resultaterne for 2010. 


\subsection{Depression}

Tabel 2.4.1. Diagnosticerede patienter med depression 2009 (Samlet) - basisindikatorer

\begin{tabular}{|c|c|c|c|c|c|c|}
\hline Land & $\begin{array}{r}\text { Antal } \\
\text { diagnostice- } \\
\text { rede patien- } \\
\text { ter med } \\
\text { depression, } \\
\text { som har haft } \\
\text { kontakt med } \\
\text { sekundær } \\
\text { sektor pr. } \\
100.000 \\
\text { indbyggere } \\
\text { pr. år (18+) }\end{array}$ & $\begin{array}{r}\text { Antal } \\
\text { diagnostice- } \\
\text { rede patien- } \\
\text { ter med } \\
\text { depression, } \\
\text { som har haft } \\
\text { kontakt med } \\
\text { sekundær } \\
\text { sektor pr. } \\
100.000 \\
\text { indbyggere } \\
\text { pr. år (18- } \\
24)\end{array}$ & $\begin{array}{r}\text { Antal } \\
\text { diagnostice- } \\
\text { rede patien- } \\
\text { ter med } \\
\text { depression, } \\
\text { som har haft } \\
\text { kontakt med } \\
\text { sekundær } \\
\text { sektor pr. } \\
100.000 \\
\text { indbyggere } \\
\text { pr. år (25- } \\
44)\end{array}$ & $\begin{array}{r}\text { Antal } \\
\text { diagnostice- } \\
\text { rede patien- } \\
\text { ter med } \\
\text { depression, } \\
\text { som har haft } \\
\text { kontakt med } \\
\text { sekundær } \\
\text { sektor pr. } \\
100.000 \\
\text { indbyggere } \\
\text { pr. år (45- } \\
64)\end{array}$ & $\begin{array}{r}\text { Antal } \\
\text { diagnostice- } \\
\text { rede patien- } \\
\text { ter med } \\
\text { depression, } \\
\text { som har haft } \\
\text { kontakt med } \\
\text { sekundær } \\
\text { sektor pr. } \\
100.000 \\
\text { indbyggere } \\
\text { pr. år (65- } \\
84)\end{array}$ & $\begin{array}{r}\text { Antal } \\
\text { diagnostice- } \\
\text { rede patien- } \\
\text { ter med } \\
\text { depression, } \\
\text { som har haft } \\
\text { kontakt med } \\
\text { sekundær } \\
\text { sektor pr. } \\
100.000 \\
\text { indbyggere } \\
\text { pr. år }(85+)\end{array}$ \\
\hline Danmark & 271,3 & 334,4 & 292,9 & 221,6 & 266,6 & 427,3 \\
\hline Finland & 808,6 & $1.423,5$ & $1.076,4$ & 971,4 & 393,5 & 173,4 \\
\hline Færøerne & 93,0 & 211,6 & 87,8 & 149,6 & 110,6 & 118,4 \\
\hline Grønland & N/A & N/A & N/A & N/A & N/A & N/A \\
\hline Island & N/A & N/A & N/A & N/A & N/A & N/A \\
\hline Norge & 744,7 & $1.131,6$ & 894,4 & 663,1 & 374,2 & 339,6 \\
\hline Sverige & 762,2 & 875,2 & 873,1 & 805,9 & 499,4 & 358,0 \\
\hline
\end{tabular}

Anm.: Finland og Færøerne har anvendt hele befolkningen som grundlag. $\varnothing$ vrige lande har anvendt 18+ befolkning. Aldersgruppen 18-24 år er erstattet af 15-24 år for Finland. For Færøerne er tallene baseret på et gennemsnit for 2005-2009. Resultater fra Norge er overestimeret jf. indledende kommentarer.

Bemærkning: Tallene for Færøerne er baseret på indlagte patienter.

Tabel 2.4.2. Diagnosticerede patienter med depression 2009 (Mænd) - basisindikatorer

\begin{tabular}{|c|c|c|c|c|c|c|}
\hline Land & $\begin{array}{r}\text { Antal } \\
\text { diagnostice- } \\
\text { rede patien- } \\
\text { ter med } \\
\text { depression, } \\
\text { som har haft } \\
\text { kontakt med } \\
\text { sekundær } \\
\text { sektor pr. } \\
100.000 \\
\text { indbyggere } \\
\text { pr. år }(18+)\end{array}$ & $\begin{array}{r}\text { Antal } \\
\text { diagnostice- } \\
\text { rede patien- } \\
\text { ter med } \\
\text { depression, } \\
\text { som har haft } \\
\text { kontakt med } \\
\text { sekundær } \\
\text { sektor pr. } \\
100.000 \\
\text { indbyggere } \\
\text { pr. år (18- } \\
24)\end{array}$ & $\begin{array}{r}\text { Antal } \\
\text { diagnostice- } \\
\text { rede patien- } \\
\text { ter med } \\
\text { depression, } \\
\text { som har haft } \\
\text { kontakt med } \\
\text { sekundær } \\
\text { sektor pr. } \\
100.000 \\
\text { indbyggere } \\
\text { pr. år (25- } \\
44)\end{array}$ & $\begin{array}{r}\text { Antal } \\
\text { diagnostice- } \\
\text { rede patien- } \\
\text { ter med } \\
\text { depression, } \\
\text { som har haft } \\
\text { kontakt med } \\
\text { sekundær } \\
\text { sektor pr. } \\
100.000 \\
\text { indbyggere } \\
\text { pr. år (45- } \\
64)\end{array}$ & $\begin{array}{r}\text { Antal } \\
\text { diagnostice- } \\
\text { rede patien- } \\
\text { ter med } \\
\text { depression, } \\
\text { som har haft } \\
\text { kontakt med } \\
\text { sekundær } \\
\text { sektor pr. } \\
100.000 \\
\text { indbyggere } \\
\text { pr. år (65- } \\
84)\end{array}$ & $\begin{array}{r}\text { Antal } \\
\text { diagnostice- } \\
\text { rede patien- } \\
\text { ter med } \\
\text { depression, } \\
\text { som har haft } \\
\text { kontakt med } \\
\text { sekundær } \\
\text { sektor pr. } \\
100.000 \\
\text { indbyggere } \\
\text { pr. år }(85+)\end{array}$ \\
\hline Danmark & 199,4 & 202,5 & 205,7 & 187,4 & 196,3 & 336,5 \\
\hline Finland & 558,3 & 818,1 & 737,4 & 714,6 & 281,3 & 150,0 \\
\hline Færøerne & 63,6 & 92,7 & 38,4 & 123,9 & 115,6 & 137,2 \\
\hline Grønland & N/A & N/A & $\mathrm{N} / \mathrm{A}$ & N/A & N/A & N/A \\
\hline Island & N/A & N/A & $\mathrm{N} / \mathrm{A}$ & $\mathrm{N} / \mathrm{A}$ & $\mathrm{N} / \mathrm{A}$ & N/A \\
\hline Norge & 552,7 & 676,9 & 644,8 & 548,6 & 257,7 & 320,3 \\
\hline Sverige & 588,3 & 620,1 & 646,8 & 654,7 & 369,0 & 308,6 \\
\hline
\end{tabular}

Anm.: Finland og Færøerne har anvendt hele befolkningen som grundlag. $\varnothing$ vrige lande har anvendt 18+ befolkning. Aldersgruppen 18-24 år er erstattet af 15-24 år for Finland. For Færøerne er tallene baseret på et gennemsnit for 2005-2009. Resultater fra Norge er overestimeret jf. indledende kommentarer.

Bemærkning: Tallene for Færøerne er baseret på indlagte patienter. 
Tabel 2.4.3. Diagnosticerede patienter med depression 2009 (Kvinder) - basisindikatorer

\begin{tabular}{|c|c|c|c|c|c|c|}
\hline Land & $\begin{array}{r}\text { Antal } \\
\text { diagnostice- } \\
\text { rede patien- } \\
\text { ter med } \\
\text { depression, } \\
\text { som har haft } \\
\text { kontakt med } \\
\text { sekundær } \\
\text { sektor pr. } \\
100.000 \\
\text { indbyggere } \\
\text { pr. år }(18+)\end{array}$ & $\begin{array}{r}\text { Antal } \\
\text { diagnostice- } \\
\text { rede patien- } \\
\text { ter med } \\
\text { depression, } \\
\text { som har haft } \\
\text { kontakt med } \\
\text { sekundær } \\
\text { sektor pr. } \\
100.000 \\
\text { indbyggere } \\
\text { pr. år (18- } \\
24)\end{array}$ & $\begin{array}{r}\text { Antal } \\
\text { diagnostice- } \\
\text { rede patien- } \\
\text { ter med } \\
\text { depression, } \\
\text { som har haft } \\
\text { kontakt med } \\
\text { sekundær } \\
\text { sektor pr. } \\
100.000 \\
\text { indbyggere } \\
\text { pr. år (25- } \\
44)\end{array}$ & $\begin{array}{r}\text { Antal } \\
\text { diagnostice- } \\
\text { rede patien- } \\
\text { ter med } \\
\text { depression, } \\
\text { som har haft } \\
\text { kontakt med } \\
\text { sekundær } \\
\text { sektor pr. } \\
100.000 \\
\text { indbyggere } \\
\text { pr. år (45- } \\
64)\end{array}$ & $\begin{array}{r}\text { Antal } \\
\text { diagnostice- } \\
\text { rede patien- } \\
\text { ter med } \\
\text { depression, } \\
\text { som har haft } \\
\text { kontakt med } \\
\text { sekundær } \\
\text { sektor pr. } \\
100.000 \\
\text { indbyggere } \\
\text { pr. år (65- } \\
84)\end{array}$ & $\begin{array}{r}\text { Antal } \\
\text { diagnostice- } \\
\text { rede patien- } \\
\text { ter med } \\
\text { depression, } \\
\text { som har haft } \\
\text { kontakt med } \\
\text { sekundær } \\
\text { sektor pr. } \\
100.000 \\
\text { indbyggere } \\
\text { pr. år (85+) }\end{array}$ \\
\hline Danmark & 340,7 & 472,1 & 381,5 & 256,0 & 326,6 & 466,9 \\
\hline Finland & $1.049,6$ & $2.050,8$ & $1.431,8$ & $1.225,1$ & 480,2 & 181,5 \\
\hline Færøerne & 123,1 & 334,3 & 145,7 & 178,1 & 106,1 & 108,5 \\
\hline Grønland & N/A & N/A & N/A & N/A & N/A & N/A \\
\hline Island & N/A & N/A & N/A & N/A & N/A & N/A \\
\hline Norge & 933,0 & $1.606,6$ & $1.155,4$ & 781,6 & 471,5 & 347,9 \\
\hline Sverige & 931,6 & $1.143,0$ & $1.108,7$ & 959,4 & 612,3 & 382,4 \\
\hline
\end{tabular}

Anm.: Finland og Færøerne har anvendt hele befolkningen som grundlag. $\varnothing$ vrige lande har anvendt 18+ befolkning. Aldersgruppen 18-24 år er erstattet af 15-24 år for Finland. For Færøerne er tallene baseret på et gennemsnit for 2005-2009. Resultater fra Norge er overestimeret jf. indledende kommentarer.

Bemærkninger til tabel 2.4.1, tabel 2.4.2. og tabel 2.4.3

Resultater fra Færøerne er ikke sammenlignelige med de øvrige landes resultater pga. det begrænsede datagrundlag. Endvidere er resultat fra Finland for $18+$ befolkningen ikke sammenlignelig med de $\varnothing$ vrige landes, da dette tal er for hele befolkningen. Sverige har med 762,2 pr. 100.000 indbyggere flest diagnosticerede patienter med depression, mens Danmark har signifikant færre med 271,3 pr. 100.000 indbyggere. Tendensen er den samme for Danmark, Finland, Norge og Sverige, når vi ser på aldersfordelingen: Der er flest diagnosticerede patienter med depression i den yngste aldersgruppe, hvorefter antallet er faldende i de ældre aldersgrupper.

Danmark skiller sig signifikant ud fra de øvrige lande, idet antallet af diagnosticerede patienter med depression begynder at stige i de ældste aldersgrupper og Danmark har flest diagnosticerede patienter med depression pr. 100.000 i aldersgruppen 85+. Sverige og især Danmark har en mere jævn fordeling af de diagnosticerede patienter end Finland og Norge. Danmark spænder fra 221,6 pr. 100.000 indbyggere i den aldersgruppe med færrest diagnosticerede patienter med depression til 427,3 pr. 100.000 i den aldersgruppe med flest. Sverige har 358,0 pr. 100.000 i den aldersgruppe med færrest, mens der er 875,2 pr. $100.000 \mathrm{i}$ aldersgruppen med flest. I Norge varierer resultatet fra 339,6 pr. 100.000 til 1.131,6 pr. 100.000 . Finland har 173,4 diagnosticerede patienter med depression pr. $100.000 \mathrm{i}$ den aldersgruppe med færrest, mens der er $1.423,5$ pr. $100.000 \mathrm{i}$ aldersgruppen med flest.

Generelt er der flere diagnosticerede kvinder med depression pr. 100.000 indbyggere end mænd, og spredningen i de forskellige aldersgrupper er også større for kvinderne end for mændene i de fleste af landene. Tallene for Færøerne er baseret på indlagte patienter. 
Tabel 2.4.4. Diagnosticerede patienter med depression og misbrugsdiagnose 2009 (Samlet) basisindikatore

\begin{tabular}{|c|c|c|c|c|c|c|}
\hline Land & $\begin{array}{r}\text { Antal diag- } \\
\text { nosticerede } \\
\text { patienter } \\
\text { med depres- } \\
\text { sion og } \\
\text { misbrugsdi- } \\
\text { agnose, som } \\
\text { har haft } \\
\text { kontakt med } \\
\text { sekundær } \\
\text { sektor pr. } \\
100.000 \\
\text { indbyggere } \\
\text { pr. år }(18+)\end{array}$ & $\begin{array}{r}\text { Antal diag- } \\
\text { nosticerede } \\
\text { patienter } \\
\text { med depres- } \\
\text { sion og } \\
\text { misbrugsdi- } \\
\text { agnose, som } \\
\text { har haft } \\
\text { kontakt med } \\
\text { sekundær } \\
\text { sektor pr. } \\
100.000 \\
\text { indbyggere } \\
\text { pr. år (18- } \\
24)\end{array}$ & $\begin{array}{r}\text { Antal diag- } \\
\text { nosticerede } \\
\text { patienter } \\
\text { med depres- } \\
\text { sion og } \\
\text { misbrugsdi- } \\
\text { agnose, som } \\
\text { har haft } \\
\text { kontakt med } \\
\text { sekundær } \\
\text { sektor pr. } \\
100.000 \\
\text { indbyggere } \\
\text { pr. år (25-44) }\end{array}$ & $\begin{array}{r}\text { Antal diag- } \\
\text { nosticerede } \\
\text { patienter } \\
\text { med depres- } \\
\text { sion og } \\
\text { misbrugsdi- } \\
\text { agnose, som } \\
\text { har haft } \\
\text { kontakt med } \\
\text { sekundær } \\
\text { sektor pr. } \\
100.000 \\
\text { indbyggere } \\
\text { pr. år (45- } \\
64)\end{array}$ & $\begin{array}{r}\text { Antal diag- } \\
\text { nosticerede } \\
\text { patienter } \\
\text { med depres- } \\
\text { sion og } \\
\text { misbrugsdi- } \\
\text { agnose, som } \\
\text { har haft } \\
\text { kontakt med } \\
\text { sekundær } \\
\text { sektor pr. } \\
100.000 \\
\text { indbyggere } \\
\text { pr. år (65- } \\
84)\end{array}$ & $\begin{array}{r}\text { Antal diag- } \\
\text { nosticerede } \\
\text { patienter } \\
\text { med depres- } \\
\text { sion og } \\
\text { misbrugsdi- } \\
\text { agnose, som } \\
\text { har haft } \\
\text { kontakt med } \\
\text { sekundær } \\
\text { sektor pr. } \\
100.000 \\
\text { indbyggere } \\
\text { pr. år }(85+)\end{array}$ \\
\hline Danmark & 24,3 & 15,8 & 24,3 & 32,4 & 16,2 & 6,4 \\
\hline Finland & 26,3 & 24,6 & 36,8 & 44,1 & 8,5 & 0,0 \\
\hline $\begin{array}{l}\text { Færøer- } \\
\text { ne }\end{array}$ & N/A & $\mathrm{N} / \mathrm{A}$ & $\mathrm{N} / \mathrm{A}$ & N/A & N/A & N/A \\
\hline Grønland & $\mathrm{N} / \mathrm{A}$ & N/A & N/A & N/A & $\mathrm{N} / \mathrm{A}$ & N/A \\
\hline Island & $N / A$ & $N / A$ & $\mathrm{~N} / \mathrm{A}$ & N/A & $\mathrm{N} / \mathrm{A}$ & N/A \\
\hline Norge & 35,7 & 54,4 & 38,8 & 40,9 & 10,9 & 1,8 \\
\hline Sverige & 28,0 & 28,0 & 31,7 & 38,0 & 9,4 & 1,6 \\
\hline
\end{tabular}

Anm.: Finland har anvendt hele befolkningen som grundlag i stedet for $18+$ befolkning. Endvidere er aldersgruppen 18-24 år erstattet af 15-24 år for Finland. Resultater fra Norge er overestimeret jf. indledende kommentarer.

Tabel 2.4.5. Diagnosticerede patienter med depression 2009 og misbrugsdiagnose (Mænd) basisindikatorer

\begin{tabular}{|c|c|c|c|c|c|c|}
\hline Land & $\begin{array}{r}\text { Antal } \\
\text { diagnostice- } \\
\text { rede patien- } \\
\text { ter med } \\
\text { depression } \\
\text { og mis- } \\
\text { brugsdiag- } \\
\text { nose, som } \\
\text { har haft } \\
\text { kontakt med } \\
\text { sekundær } \\
\text { sektor pr. } \\
100.000 \\
\text { indbyggere } \\
\text { pr. år (18+) }\end{array}$ & $\begin{array}{r}\text { Antal } \\
\text { diagnostice- } \\
\text { rede patien- } \\
\text { ter med } \\
\text { depression } \\
\text { og mis- } \\
\text { brugsdiag- } \\
\text { nose, som } \\
\text { har haft } \\
\text { kontakt med } \\
\text { sekundær } \\
\text { sektor pr. } \\
100.000 \\
\text { indbyggere } \\
\text { pr. år (18- } \\
24)\end{array}$ & $\begin{array}{r}\text { Antal } \\
\text { diagnostice- } \\
\text { rede patien- } \\
\text { ter med } \\
\text { depression } \\
\text { og mis- } \\
\text { brugsdiag- } \\
\text { nose, som } \\
\text { har haft } \\
\text { kontakt med } \\
\text { sekundær } \\
\text { sektor pr. } \\
100.000 \\
\text { indbyggere } \\
\text { pr. år (25- } \\
44)\end{array}$ & $\begin{array}{r}\text { Antal } \\
\text { diagnostice- } \\
\text { rede patien- } \\
\text { ter med } \\
\text { depression } \\
\text { og mis- } \\
\text { brugsdiag- } \\
\text { nose, som } \\
\text { har haft } \\
\text { kontakt med } \\
\text { sekundær } \\
\text { sektor pr. } \\
100.000 \\
\text { indbyggere } \\
\text { pr. år (45- } \\
64)\end{array}$ & $\begin{array}{r}\text { Antal } \\
\text { diagnostice- } \\
\text { rede patien- } \\
\text { ter med } \\
\text { depression } \\
\text { og mis- } \\
\text { brugsdiag- } \\
\text { nose, som } \\
\text { har haft } \\
\text { kontakt med } \\
\text { sekundær } \\
\text { sektor pr. } \\
100.000 \\
\text { indbyggere } \\
\text { pr. år (65- } \\
84)\end{array}$ & $\begin{array}{r}\text { Antal } \\
\text { diagnostice- } \\
\text { rede patien- } \\
\text { ter med } \\
\text { depression } \\
\text { og mis- } \\
\text { brugsdiag- } \\
\text { nose, som } \\
\text { har haft } \\
\text { kontakt med } \\
\text { sekundær } \\
\text { sektor pr. } \\
100.000 \\
\text { indbyggere } \\
\text { pr. år (85+) }\end{array}$ \\
\hline Danmark & 27,2 & 14,6 & 30,4 & 35,0 & 14,5 & 3,0 \\
\hline Finland & 32,6 & 22,6 & 47,0 & 54,0 & 11,0 & 0,0 \\
\hline Færøerne & $\mathrm{N} / \mathrm{A}$ & $\mathrm{N} / \mathrm{A}$ & N/A & N/A & N/A & N/A \\
\hline Grønland & N/A & N/A & N/A & N/A & N/A & N/A \\
\hline Island & N/A & N/A & N/A & N/A & N/A & N/A \\
\hline Norge & 45,3 & 55,6 & 53,1 & 50,6 & 10,3 & 0,0 \\
\hline Sverige & 35,4 & 31,0 & 39,9 & 48,0 & 10,8 & 3,7 \\
\hline
\end{tabular}

Anm.: Finland har anvendt hele befolkningen som grundlag i stedet for $18+$ befolkning. Endvidere er aldersgruppen 18-24 år erstattet af 15-24 år for Finland. Resultater fra Norge er overestimeret jf. indledende kommentarer. 
Tabel 2.4.6. Diagnosticerede patienter med depression og misbrugsdiagnose 2009 (Kvinder) basisindikatorer

\begin{tabular}{|c|c|c|c|c|c|c|}
\hline Land & $\begin{array}{r}\text { Antal } \\
\text { diagnostice- } \\
\text { rede patien- } \\
\text { ter med } \\
\text { depression } \\
\text { og mis- } \\
\text { brugsdiag- } \\
\text { nose, som } \\
\text { har haft } \\
\text { kontakt med } \\
\text { sekundær } \\
\text { sektor pr. } \\
100.000 \\
\text { indbyggere } \\
\text { pr. år (18+) }\end{array}$ & $\begin{array}{r}\text { Antal } \\
\text { diagnostice- } \\
\text { rede patien- } \\
\text { ter med } \\
\text { depression } \\
\text { og mis- } \\
\text { brugsdiag- } \\
\text { nose, som } \\
\text { har haft } \\
\text { kontakt med } \\
\text { sekundær } \\
\text { sektor pr. } \\
100.000 \\
\text { indbyggere } \\
\text { pr. år (18- } \\
24)\end{array}$ & $\begin{array}{r}\text { Antal } \\
\text { diagnostice- } \\
\text { rede patien- } \\
\text { ter med } \\
\text { depression } \\
\text { og mis- } \\
\text { brugsdiag- } \\
\text { nose, som } \\
\text { har haft } \\
\text { kontakt med } \\
\text { sekundær } \\
\text { sektor pr. } \\
100.000 \\
\text { indbyggere } \\
\text { pr. år (25- } \\
44)\end{array}$ & $\begin{array}{r}\text { Antal } \\
\text { diagnostice- } \\
\text { rede patien- } \\
\text { ter med } \\
\text { depression } \\
\text { og mis- } \\
\text { brugsdiag- } \\
\text { nose, som } \\
\text { har haft } \\
\text { kontakt med } \\
\text { sekundær } \\
\text { sektor pr. } \\
100.000 \\
\text { indbyggere } \\
\text { pr. år (45- } \\
64)\end{array}$ & $\begin{array}{r}\text { Antal } \\
\text { diagnostice- } \\
\text { rede patien- } \\
\text { ter med } \\
\text { depression } \\
\text { og mis- } \\
\text { brugsdiag- } \\
\text { nose, som } \\
\text { har haft } \\
\text { kontakt med } \\
\text { sekundær } \\
\text { sektor pr. } \\
100.000 \\
\text { indbyggere } \\
\text { pr. år (65- } \\
84)\end{array}$ & $\begin{array}{r}\text { Antal } \\
\text { diagnostice- } \\
\text { rede patien- } \\
\text { ter med } \\
\text { depression } \\
\text { og mis- } \\
\text { brugsdiag- } \\
\text { nose, som } \\
\text { har haft } \\
\text { kontakt med } \\
\text { sekundær } \\
\text { sektor pr. } \\
100.000 \\
\text { indbyggere } \\
\text { pr. år }(85+)\end{array}$ \\
\hline Danmark & 21,5 & 17,1 & 18,2 & 29,8 & 17,6 & 7,9 \\
\hline Finland & 20,4 & 26,6 & 26,1 & 34,1 & 6,6 & 0,0 \\
\hline Færøerne & N/A & N/A & N/A & N/A & N/A & N/A \\
\hline Grønland & N/A & N/A & $\mathrm{N} / \mathrm{A}$ & $\mathrm{N} / \mathrm{A}$ & N/A & N/A \\
\hline Island & $\mathrm{N} / \mathrm{A}$ & $\mathrm{N} / \mathrm{A}$ & $\mathrm{N} / \mathrm{A}$ & $\mathrm{N} / \mathrm{A}$ & N/A & N/A \\
\hline Norge & 26,3 & 53,2 & 23,7 & 30,9 & 11,4 & 2,6 \\
\hline Sverige & 20,8 & 24,9 & 23,2 & 27,8 & 8,1 & 0,6 \\
\hline
\end{tabular}

Anm.: Finland har anvendt hele befolkningen som grundlag i stedet for $18+$ befolkning. Endvidere er aldersgruppen 18-24 år erstattet af 15-24 år for Finland. Resultater fra Norge er overestimeret jf. indledende kommentarer.

Bemærkninger til tabel 2.4.4, tabel 2.4.5 og tabel 2.4.6:

Resultatet fra Finland for 18+ befolkningen er underestimeret pga. at der er anvendt hele befolkningen som grundlag, hvorfor dette resultat ikke er sammenligneligt med de $\varnothing$ vrige landes. Danmark har med 24,3 pr. 100.000 indbyggere færrest diagnosticerede patienter med depression og misbrugsdiagnose, mens Norge med 35,7 pr. 100.000 indbyggere har flest. Norge har endvidere også den største spredning i aldersgrupperne fra 1,8 pr. 100.000 til 54,4 pr. 100.000. Norge har flest diagnosticerede patienter med depression og misbrugsdiagnose i den yngste aldersgruppe fra 18-24 år, mens de øvrige lande har flest i aldersgruppen 45-64 år.

Generelt er der flere diagnosticerede mænd med depression og misbrugsdiagnose end kvinder. For diagnosticered mænd med depression og misbrugsdiagnose er billedet det samme som den samlede befolkning, hvor Norge har flest, mens Danmark har færrest diagnosticerede patienter med depression og misbrugsdiagnose. Norge har flest diagnosticerede kvinder med depression og misbrugsdiagnose pr. 100.000 indbyggere, mens Finland har færrest. 
Tabel 2.4.7. Dødelighed for patienter med depression 2009 - basisindikatorer

\begin{tabular}{|c|c|c|c|c|c|c|}
\hline Land & $\begin{array}{r}\text { Andelen } \\
\text { af } \\
\text { indlagte } \\
\text { patien- } \\
\text { ter, der } \\
\text { dør } \\
\text { inden } \\
\text { for } 30 \\
\text { dage } \\
\text { efter } \\
\text { udskri- } \\
\text { velse fra } \\
\text { psykia- } \\
\text { trisk } \\
\text { afdeling }\end{array}$ & $\begin{array}{r}\text { Andelen } \\
\text { af } \\
\text { indlagte } \\
\text { patien- } \\
\text { ter, der } \\
\text { dør } \\
\text { inden } \\
\text { for } 60 \\
\text { dage } \\
\text { efter } \\
\text { udskri- } \\
\text { velse fra } \\
\text { psykia- } \\
\text { trisk } \\
\text { afdeling }\end{array}$ & $\begin{array}{r}\text { Andelen } \\
\text { af } \\
\text { indlagte } \\
\text { patien- } \\
\text { ter, der } \\
\text { dør } \\
\text { inden for } \\
90 \text { dage } \\
\text { efter } \\
\text { udskri- } \\
\text { velse fra } \\
\text { psykia- } \\
\text { trisk } \\
\text { afdeling }\end{array}$ & $\begin{array}{r}\text { Andel självmord inom ett } \\
\text { år för patienter med } \\
\text { kontakt med psykiatrin for } \\
\text { depression. Samtliga } \\
\text { patienter som vårdats } \\
\text { inom specialiserad psykia- } \\
\text { trisk vård (som inlagd eller } \\
\text { med läkarbesök i öppen } \\
\text { vård) under ett kalenderår } \\
\text { (räknat från första besöks- } \\
\text { datum för året eller första } \\
\text { inläggningsdagen vid } \\
\text { första inskrivningen). }\end{array}$ & $\begin{array}{r}\text { Antallet af } \\
\text { dødsfald pr. } \\
10.000 \text { ind- } \\
\text { byggere med } \\
\text { depression der } \\
\text { på et eller } \\
\text { andet tids- } \\
\text { punkt inden- } \\
\text { for de sidste } 5 \\
\text { år er blevet } \\
\text { behandlet for } \\
\text { depression } \\
\text { (20-59 år) }\end{array}$ & $\begin{array}{r}\text { Antallet af } \\
\text { dødsfald i } \\
\text { befolknin- } \\
\text { gen pr. } \\
10.000 \\
\text { indbygge- } \\
\text { re (20-59 } \\
\text { år) }\end{array}$ \\
\hline Danmark & $0,66 \%$ & $0,89 \%$ & $1,02 \%$ & $0,23 \%$ & 35,0 & 23,6 \\
\hline Finland & $0,18 \%$ & N/A & N/A & N/A & 282,5 & 24,5 \\
\hline Færøerne & $0,4 \%$ & $0,4 \%$ & $0,4 \%$ & N/A & 75,2 & 17,3 \\
\hline Grønland & $\mathrm{N} / \mathrm{A}$ & $\mathrm{N} / \mathrm{A}$ & $\mathrm{N} / \mathrm{A}$ & N/A & $\mathrm{N} / \mathrm{A}$ & $\mathrm{N} / \mathrm{A}$ \\
\hline Island & N/A & N/A & N/A & N/A & N/A & N/A \\
\hline Norge & N/A & N/A & N/A & $\mathrm{N} / \mathrm{A}$ & N/A & N/A \\
\hline Sverige & $0,33 \%$ & $0,54 \%$ & $0,70 \%$ & $0,42 \%$ & 49,2 & 15,26 \\
\hline
\end{tabular}

Anm.: For selvmord gælder, at selvmordet er sket i 2009, men patienten kan have haft seneste kontakt med psykiatrisk afdeling i 2008.

Bemærkninger: Resultater fra Færøerne er ikke sammenlignelige med de øvrige landes pga. det begrænsede datagrundlag jf. de indledende kommentarer. Tabellen viser, at andelen af indlagte depressionspatienter, der dør inden for 30 dage efter udskrivelse fra psykiatrisk afdeling er st $\varnothing$ rst i Danmark med 0,66 pct., mens Finland har den laveste andel på 0,18 pct. Endvidere er andelen af indlagte depressionspatienter, der dør inden hhv. 60 og 90 dage størst i Danmark med hhv. 0,89 pct. og 1,02 pct., mens Sverige andel udg $\varnothing \mathrm{r} 0,54$ pct. og 0,70 pct. for hhv. 60 og 90 dage.

Vedrørende selvmord indenfor 1 år efter indskrivning, så har Sverige den største andel med 0,42 pct. mod Danmarks 0,23 pct. Den sidste indikator for dødelighed for patienter med depression er antallet af d $\varnothing$ dsfald pr. 10.000 indbyggere. Disse resultater viser, at dødeligheden er større for personer der indenfor de sidste 5 år er blevet behandlet for depression.

Ud fra dette kan det konkluderes, at der er større sandsynlighed for dødsfald, hvis man har eller for nyligt har haft en depression, end hvis man ikke har haft det.

Sverige har 49,2 dødsfald blandt depressionspatienter pr. 10.000 depressionspatienter mod 15,26 dødsfald i den samlede befolkning pr. 10.000 indbyggere i alt, mens Danmark for depressionspatienter har $35 \mathrm{~d} \varnothing \mathrm{dsfald}$ pr.10.000 mod 23,6 d $\varnothing \mathrm{dsfald} \mathrm{pr.} 10.000$ indbyggere i alt. Tallene for Færøerne er baseret på indlagte patienter.

Tabel 2.4.8. Genindlæggelser for depression - kvalitetsindikatorer

\begin{tabular}{lrr}
\hline Land & $\begin{array}{r}\text { Genindlæggelse på psykiatrisk afdeling } \\
\text { for depression (14 til 28 dage) }\end{array}$ & $\begin{array}{r}\text { Genindlæggelse på psykiatrisk afde- } \\
\text { ling for depression (3 til 6 måneder) }\end{array}$ \\
\hline Danmark & $8,02 \%$ & $4,12 \%$ \\
Finland & $0,55 \%$ & $2,27 \%$ \\
Færøerne & $7,40 \%$ & $7,70 \%$ \\
Grønland & $\mathrm{N} / \mathrm{A}$ & $\mathrm{N} / \mathrm{A}$ \\
Island & $\mathrm{N} / \mathrm{A}$ & $\mathrm{N} / \mathrm{A}$ \\
Norge & $6,30 \%$ & $4,10 \%$ \\
Sverige & $\mathrm{N} / \mathrm{A}$ & $\mathrm{N} / \mathrm{A}$ \\
\hline
\end{tabular}

Anm.: For Færøerne er tallene baseret på et gennemsnit for 2005-2009.

Bemærkninger: Resultater fra Færøerne er ikke sammenlignelige med de øvrige landes pga. det begrænsede datagrundlag jf. de indledende kommentarer. Danmark har den største genindlæggelsesprocent for mellem 14 til 28 dage på 8,02 pct., mens Finland har den laveste med 0,55 pct.

Med hensyn til genindlæggelser mellem 3 til 6 måneder, så har Danmark den største rate på 4,12 pct., men Norge har en rate på 4,10 pct.. Finland har den laveste genindlæggelsesrate på 2,27 pct., men har som det eneste af de tre lande en større rate efter 3 til 6 måneder end efter 14 til 28 dage. Tallene for Færøerne er baseret på indlagte patienter. 
Tabel 2.4.9. Följsamhet till behandling med antidepressiva läkemedel, undvikbar somatisk slutenvård och återinskrivningar efter psykiatrisk vård för depressionsjukdom - kvalitetsindikatorer

\begin{tabular}{lr} 
& Sverige \\
\hline Följsamhet till behandling med antidepressiva läkemedel. Antal personer 18 år och äldre på & $53 \%$ \\
antidepressiv medicinering som hämtat ut ytterligare ett recept på antidepressiva 60 till 150 & \\
dagar efter det första medicinuttaget på apotek. & 1.902 \\
Undvikbar somatisk slutenvård efter vård inom psykiatrin pr. 100.000 invånare (Män) & 1.596 \\
Undvikbar somatisk slutenvård efter vård inom psykiatrin pr. 100.000 invånare (Kvinnor) & $10 \%$ \\
Återinskrivning inom 14 dagar efter sluten vård för depression & $14 \%$ \\
Återinskrivning inom 28 dagar & $23 \%$ \\
Återinskrivning inom 3 månader & $30 \%$ \\
Återinskrivning inom 6 månader & $30 \%$ \\
\hline
\end{tabular}

Anm.: Data for undvikbara somatiska slutenvårdstillfällen efter vård inom psykiatrin er for 2008 och patienter mellan 20-59 år. Som undvikbar slutenvård räknas till exempel vård för diagnoserna astma, diabetes, hjärtsvikt och KOL En jämförelse görs också i Sverige med en population utan tidigare psykiatrisk vård. For följsamhet till behandling med antidepressiva läkemedel gäller: 18 år och äldre. Andel som hämtade ut ett recept på antidepressiva under första halvåret 2009 (som inte stod på medicinen sista halvåret 2008) och som hämtade ut minst ett recept 2-5 månader senare.

Bemærkninger: Indikatorn undvikbar somatisk slutenvård ska belysa omhändertagandet vid vissa speicificerade sjukdomstillstånd inom den öppna vården, till exempel genom en fungerande primärvård och förebyggande folkhälsoarbete. Som undvikbar slutenvård räknas till exempel vård för diagnoserna astma, diabetes, hjärtsvikt och KOL. En jämförelse görs också med en population utan tidigare psykiatrisk vård.Tanken är att man kan förhindra onödiga inläggningar på sjukhus om patienter får ett bra omhändertagande i den öppna somatiska vården. För mera information om indikatorerna hänvisas till rapport http://www.socialstyrelsen.se/Lists/ Artikelkatalog/Attachments/18050/2010-6-6.pdf

\subsection{Bipolar lidelse}

Tabel 2.5.1. Nydiagnosticerede patienter med bipolar lidelse - basisindikatorer

\begin{tabular}{|c|c|c|c|c|c|c|}
\hline Land & $\begin{array}{r}\text { Antal nydi- } \\
\text { agnosticere- } \\
\text { de patienter } \\
\text { med bipolar } \\
\text { lidelse med } \\
\text { kontakt til } \\
\text { sekundær } \\
\text { sektor pr. år } \\
\text { (Samlet) }\end{array}$ & $\begin{array}{r}\text { Samlet antal } \\
\text { nydiagnosticere- } \\
\text { de patienter med } \\
\text { bipolar lidelse } \\
\text { med kontakt til } \\
\text { sekundær sektor } \\
\text { pr. } 100.000 \\
\text { indbyggere pr. år } \\
\text { (Samlet) }\end{array}$ & $\begin{array}{r}\text { Antal } \\
\text { nydiagnosti- } \\
\text { cerede } \\
\text { patienter } \\
\text { med bipolar } \\
\text { lidelse med } \\
\text { kontakt til } \\
\text { sekundær } \\
\text { sektor pr. år } \\
\text { (Mænd) }\end{array}$ & $\begin{array}{r}\text { Samlet antal } \\
\text { nydiagnosticere- } \\
\text { de patienter } \\
\text { med bipolar } \\
\text { lidelse med } \\
\text { kontakt til } \\
\text { sekundær sektor } \\
\text { pr. 100.000 } \\
\text { indbyggere pr. år } \\
\text { (Mænd) }\end{array}$ & $\begin{array}{r}\text { Antal nydi- } \\
\text { agnosticere- } \\
\text { de patienter } \\
\text { med bipolar } \\
\text { lidelse med } \\
\text { kontakt til } \\
\text { sekundær } \\
\text { sektor pr. år } \\
\text { (Kvinder) }\end{array}$ & $\begin{array}{r}\text { Samlet antal } \\
\text { nydiagnosticere- } \\
\text { de patienter } \\
\text { med bipolar } \\
\text { lidelse med } \\
\text { kontakt til } \\
\text { sekundær sektor } \\
\text { pr. 100.000 } \\
\text { indbyggere pr. år } \\
\text { (Kvinder) }\end{array}$ \\
\hline Danmark & 1.256 & 22,8 & 548 & 20,0 & 708 & 25,4 \\
\hline Finland & 2.908 & 54,3 & 1.225 & 46,7 & 1.683 & 61,7 \\
\hline Færøerne & 2,8 & 5,8 & 0,6 & 2,4 & 4,0 & 17,2 \\
\hline Grønland & N/A & N/A & $\mathrm{N} / \mathrm{A}$ & $\mathrm{N} / \mathrm{A}$ & $\mathrm{N} / \mathrm{A}$ & N/A \\
\hline Island & N/A & N/A & $\mathrm{N} / \mathrm{A}$ & $\mathrm{N} / \mathrm{A}$ & N/A & N/A \\
\hline Norge & N/A & $\mathrm{N} / \mathrm{A}$ & N/A & N/A & N/A & N/A \\
\hline Sverige & 9.541 & 129,4 & 3.718 & 102,2 & 5.823 & 155,8 \\
\hline
\end{tabular}

Anm.: For Færøerne er tallene baseret på et gennemsnit for 2005-2009. I Sverige er nydiagnosticerede beregnet som patienter, der ikke har haft en diagnose et år inden indskrivningsdato/bes $\varnothing$ gsdato. Finland og Færøerne har anvendt hele befolkningen som grundlag. Øvrige lande har anvendt $18+$ befolkningen. Tallene for Finland er for indlagte.

Bemærkninger: Resultaterne for nydiagnosticerede patienter med bipolar lidelse er ikke sammenlignelige. Færøerne har et lille datagrundlag jf. de indledende kommentarer. Sverige har beregnet nydiagnosticerede ud fra en anden definition, hvilket betyder, at flere patienter indgår. Tallene for Finland er for indlagte patienter. Finland og Færøerne har anvendt hele befolkningen som grundlag for tallene pr. 100.000 indbyggere. $\emptyset$ vrige lande har anvendt den voksne befolkning, hvilket betyder at tallene bliver underestimerede og derved ikke sammenlignelige. Generelt kan det siges, at det for alle fire lande gælder, at flere kvinder end mænd bliver nydiagnosticeret med bipolar lidelse. Tallene for Færøerne er baseret på indlagte patienter. 
Tabel 2.5.2 Nydiagnosticerede patienter med bipolar lidelse og misbrugsdiagnose - basisindikatorer

\begin{tabular}{|c|c|c|c|c|c|c|}
\hline Land & $\begin{array}{r}\text { Antal nydiag- } \\
\text { nosticerede } \\
\text { patienter med } \\
\text { bipolar lidelse } \\
\text { og misbrugs- } \\
\text { diagnose med } \\
\text { kontakt til } \\
\text { sekundær } \\
\text { sektor pr. år } \\
\text { (Samlet) }\end{array}$ & $\begin{array}{r}\text { Samlet antal } \\
\text { nydiagnosti- } \\
\text { cerede } \\
\text { patienter med } \\
\text { bipolar lidelse } \\
\text { og misbrugs- } \\
\text { diagnose med } \\
\text { kontakt til } \\
\text { sekundær } \\
\text { sektor pr. } \\
100.000 \\
\text { indbyggere } \\
\text { pr. år (Samlet) }\end{array}$ & $\begin{array}{r}\text { Antal } \\
\text { nydiagnosti- } \\
\text { cerede } \\
\text { patienter } \\
\text { med bipolar } \\
\text { lidelse og } \\
\text { misbrugsdi- } \\
\text { agnose med } \\
\text { kontakt til } \\
\text { sekundær } \\
\text { sektor pr. år } \\
\text { (Mænd) }\end{array}$ & $\begin{array}{r}\text { Samlet antal } \\
\text { nydiagnostice- } \\
\text { rede patienter } \\
\text { med bipolar } \\
\text { lidelse og } \\
\text { misbrugsdiag- } \\
\text { nose med } \\
\text { kontakt til } \\
\text { sekundær } \\
\text { sektor pr. } \\
100.000 \\
\text { indbyggere pr. } \\
\text { år (Mænd) }\end{array}$ & $\begin{array}{r}\text { Antal } \\
\text { nydiagno- } \\
\text { sticerede } \\
\text { patienter } \\
\text { med bipolar } \\
\text { lidelse og } \\
\text { misbrugsdi- } \\
\text { agnose med } \\
\text { kontakt til } \\
\text { sekundær } \\
\text { sektor pr. år } \\
\text { (Kvinder) }\end{array}$ & $\begin{array}{r}\text { Samlet antal } \\
\text { nydiagnostice- } \\
\text { rede patienter } \\
\text { med bipolar } \\
\text { lidelse og } \\
\text { misbrugsdiag- } \\
\text { nose med } \\
\text { kontakt til } \\
\text { sekundær } \\
\text { sektor pr. } \\
100.000 \text { ind- } \\
\text { byggere pr. år } \\
\text { (Kvinder) }\end{array}$ \\
\hline Danmark & 150 & 2,7 & 96 & 3,5 & 54 & 1,9 \\
\hline Finland & 192 & 3,6 & 125 & 4,8 & 67 & 2,5 \\
\hline Færøerne & N/A & N/A & $\mathrm{N} / \mathrm{A}$ & N/A & $\mathrm{N} / \mathrm{A}$ & N/A \\
\hline Grønland & N/A & $\mathrm{N} / \mathrm{A}$ & $\mathrm{N} / \mathrm{A}$ & N/A & $\mathrm{N} / \mathrm{A}$ & $\mathrm{N} / \mathrm{A}$ \\
\hline Island & N/A & $\mathrm{N} / \mathrm{A}$ & $\mathrm{N} / \mathrm{A}$ & N/A & $\mathrm{N} / \mathrm{A}$ & $\mathrm{N} / \mathrm{A}$ \\
\hline Norge & N/A & $\mathrm{N} / \mathrm{A}$ & N/A & N/A & N/A & $\mathrm{N} / \mathrm{A}$ \\
\hline Sverige & 624 & 8,5 & 354 & 9,7 & 270 & 7,2 \\
\hline
\end{tabular}

Anm.: I Sverige er nydiagnosticerede beregnet som patienter, der ikke har haft en diagnose et år inden indskrivningsdato/bes $\varnothing$ gsdato. Finland har anvendt hele befolkningen som grundlag. Øvrige lande har anvendt $18+$ befolkningen. Tal fra Finland er for indlagte og ikke ambulante patienter.

Bemærkninger: Tallene for nydiagnosticerede patienter med bipolar lidelse og misbrugsdiagnose er ikke sammenlignelige, da Sverige har anvendt en anden opgørelsesmetode. Tallene for Finland er for indlagte patienter. Generelt for de tre lande er der flere nydiagnosticere mænd end kvinder med bipolar lidelse og misbrugsdiagnose.

Tabel 2.5.3. Diagnosticerede patienter med bipolar lidelse 2009 (Samlet) - basisindikatorer

\begin{tabular}{|c|c|c|c|c|c|c|}
\hline Land & $\begin{array}{r}\text { Antal } \\
\text { diagnostice- } \\
\text { rede patien- } \\
\text { ter med } \\
\text { bipolar } \\
\text { lidelse, som } \\
\text { har haft } \\
\text { kontakt med } \\
\text { sekundær } \\
\text { sektor pr. } \\
100.000 \\
\text { indbyggere } \\
\text { pr. år (18+) }\end{array}$ & $\begin{array}{r}\text { Antal } \\
\text { diagnostice- } \\
\text { rede patien- } \\
\text { ter med } \\
\text { bipolar } \\
\text { lidelse, som } \\
\text { har haft } \\
\text { kontakt med } \\
\text { sekundær } \\
\text { sektor pr. } \\
100.000 \\
\text { indbyggere } \\
\text { pr. år (18- } \\
24)\end{array}$ & $\begin{array}{r}\text { Antal } \\
\text { diagnostice- } \\
\text { rede patien- } \\
\text { ter med } \\
\text { bipolar } \\
\text { lidelse, som } \\
\text { har haft } \\
\text { kontakt med } \\
\text { sekundær } \\
\text { sektor pr. } \\
100.000 \\
\text { indbyggere } \\
\text { pr. år (25- } \\
44)\end{array}$ & $\begin{array}{r}\text { Antal } \\
\text { diagnostice- } \\
\text { rede patien- } \\
\text { ter med } \\
\text { bipolar } \\
\text { lidelse, som } \\
\text { har haft } \\
\text { kontakt med } \\
\text { sekundær } \\
\text { sektor pr. } \\
100.000 \\
\text { indbyggere } \\
\text { pr. år (45- } \\
64)\end{array}$ & $\begin{array}{r}\text { Antal } \\
\text { diagnostice- } \\
\text { rede patien- } \\
\text { ter med } \\
\text { bipolar } \\
\text { lidelse, som } \\
\text { har haft } \\
\text { kontakt med } \\
\text { sekundær } \\
\text { sektor pr. } \\
100.000 \\
\text { indbyggere } \\
\text { pr. år (65- } \\
84)\end{array}$ & $\begin{array}{r}\text { Antal } \\
\text { diagnostice- } \\
\text { rede patien- } \\
\text { ter med } \\
\text { bipolar } \\
\text { lidelse, som } \\
\text { har haft } \\
\text { kontakt med } \\
\text { sekundær } \\
\text { sektor pr. } \\
100.000 \\
\text { indbyggere } \\
\text { pr. år (85+) }\end{array}$ \\
\hline Danmark & 76,3 & 43,8 & 71,5 & 93,2 & 73,4 & 41,4 \\
\hline Finland & 181,4 & 173,3 & 298,8 & 247,4 & 84,7 & 9,2 \\
\hline Færøerne & 39,7 & 9,2 & 22,3 & 96,3 & 72,6 & 71,0 \\
\hline Grønland & $N / A$ & $N / A$ & $\mathrm{~N} / \mathrm{A}$ & $\mathrm{N} / \mathrm{A}$ & $\mathrm{N} / \mathrm{A}$ & $\mathrm{N} / \mathrm{A}$ \\
\hline Island & N/A & N/A & N/A & N/A & N/A & $\mathrm{N} / \mathrm{A}$ \\
\hline Norge & 193,5 & 169,9 & 234,5 & 211,4 & 107,7 & 46,9 \\
\hline Sverige & 264,0 & 194,8 & 270,5 & 327,1 & 221,0 & 73,9 \\
\hline
\end{tabular}

Anm.: Finland og Færøerne har anvendt hele befolkningen. Øvrige lande har anvendt 18+ befolkning Endvidere er aldersgruppen 18-24 år erstattet af 15-24 år for Finland. For Færøerne er tallene baseret på et gennemsnit for 2005-2009. Resultater fra Norge er overestimeret jf. indledende kommentarer.

Bemærkning: Tallene for Færøerne er baseret på indlagte patienter. 
Tabel 2.5.4. Diagnosticerede patienter med bipolar lidelse 2009 (Mænd) - basisindikatorer

\begin{tabular}{|c|c|c|c|c|c|c|}
\hline Land & $\begin{array}{r}\text { Antal } \\
\text { diagnostice- } \\
\text { rede patien- } \\
\text { ter med } \\
\text { bipolar } \\
\text { lidelse, som } \\
\text { har haft } \\
\text { kontakt med } \\
\text { sekundær } \\
\text { sektor pr. } \\
100.000 \\
\text { indbyggere } \\
\text { pr. år (18+) }\end{array}$ & $\begin{array}{r}\text { Antal } \\
\text { diagnostice- } \\
\text { rede patien- } \\
\text { ter med } \\
\text { bipolar } \\
\text { lidelse, som } \\
\text { har haft } \\
\text { kontakt med } \\
\text { sekundær } \\
\text { sektor pr. } \\
100.000 \\
\text { indbyggere } \\
\text { pr. år (18- } \\
24)\end{array}$ & $\begin{array}{r}\text { Antal } \\
\text { diagnostice- } \\
\text { rede patien- } \\
\text { ter med } \\
\text { bipolar } \\
\text { lidelse, som } \\
\text { har haft } \\
\text { kontakt med } \\
\text { sekundær } \\
\text { sektor pr. } \\
100.000 \\
\text { indbyggere } \\
\text { pr. år (25- } \\
44)\end{array}$ & $\begin{array}{r}\text { Antal } \\
\text { diagnostice- } \\
\text { rede patien- } \\
\text { ter med } \\
\text { bipolar } \\
\text { lidelse, som } \\
\text { har haft } \\
\text { kontakt med } \\
\text { sekundær } \\
\text { sektor pr. } \\
100.000 \\
\text { indbyggere } \\
\text { pr. år (45- } \\
64)\end{array}$ & $\begin{array}{r}\text { Antal } \\
\text { diagnostice- } \\
\text { rede patien- } \\
\text { ter med } \\
\text { bipolar } \\
\text { lidelse, som } \\
\text { har haft } \\
\text { kontakt med } \\
\text { sekundær } \\
\text { sektor pr. } \\
100.000 \\
\text { indbyggere } \\
\text { pr. år (65- } \\
84)\end{array}$ & $\begin{array}{r}\text { Antal } \\
\text { diagnostice- } \\
\text { rede patien- } \\
\text { ter med } \\
\text { bipolar } \\
\text { lidelse, som } \\
\text { har haft } \\
\text { kontakt med } \\
\text { sekundær } \\
\text { sektor pr. } \\
100.000 \\
\text { indbyggere } \\
\text { pr. år }(85+)\end{array}$ \\
\hline Danmark & 62,7 & 36,2 & 56,6 & 83,0 & 51,2 & 9,1 \\
\hline Finland & 153,1 & 108,6 & 239,6 & 221,7 & 80,4 & 7,1 \\
\hline Færøerne & 20,7 & 0,0 & 11,8 & 48,9 & 43,4 & 68,6 \\
\hline Grønland & N/A & N/A & N/A & N/A & N/A & N/A \\
\hline Island & N/A & N/A & N/A & N/A & N/A & N/A \\
\hline Norge & 159,0 & 104,6 & 188,2 & 183,1 & 85,5 & 51,9 \\
\hline Sverige & 204,4 & 112,9 & 190,0 & 271,5 & 186,2 & 67,6 \\
\hline
\end{tabular}

Anm.: Finland og Færøerne har anvendt hele befolkningen. $\varnothing$ vrige lande har anvendt $18+$ befolkning Endvidere er aldersgruppen 18-24 år erstattet af 15-24 år for Finland. For Færøerne er tallene baseret på et gennemsnit for 2005-2009. Resultater fra Norge er overestimeret jf. indledende kommentarer.

Bemærkning: Tallene for Færøerne er baseret på indlagte patienter. 
Tabel 2.5.5. Diagnosticerede patienter med bipolar lidelse 2009 (Kvinder) - basisindikatorer

\begin{tabular}{|c|c|c|c|c|c|c|}
\hline Land & $\begin{array}{r}\text { Antal diag- } \\
\text { nosticerede } \\
\text { patienter } \\
\text { med bipolar } \\
\text { lidelse, som } \\
\text { har haft } \\
\text { kontakt med } \\
\text { sekundær } \\
\text { sektor pr. } \\
100.000 \\
\text { indbyggere } \\
\text { pr. år (18+) }\end{array}$ & $\begin{array}{r}\text { Antal diag- } \\
\text { nosticerede } \\
\text { patienter } \\
\text { med bipolar } \\
\text { lidelse, som } \\
\text { har haft } \\
\text { kontakt med } \\
\text { sekundær } \\
\text { sektor pr. } \\
100.000 \\
\text { indbyggere } \\
\text { pr. år (18-24) }\end{array}$ & $\begin{array}{r}\text { Antal diag- } \\
\text { nosticerede } \\
\text { patienter } \\
\text { med bipolar } \\
\text { lidelse, som } \\
\text { har haft } \\
\text { kontakt med } \\
\text { sekundær } \\
\text { sektor pr. } \\
100.000 \\
\text { indbyggere } \\
\text { pr. år (25-44) }\end{array}$ & $\begin{array}{r}\text { Antal diag- } \\
\text { nosticerede } \\
\text { patienter } \\
\text { med bipolar } \\
\text { lidelse, som } \\
\text { har haft } \\
\text { kontakt med } \\
\text { sekundær } \\
\text { sektor pr. } \\
100.000 \\
\text { indbyggere } \\
\text { pr. år (45-64) }\end{array}$ & $\begin{array}{r}\text { Antal diag- } \\
\text { nosticerede } \\
\text { patienter } \\
\text { med bipolar } \\
\text { lidelse, som } \\
\text { har haft } \\
\text { kontakt med } \\
\text { sekundær } \\
\text { sektor pr. } \\
100.000 \\
\text { indbyggere } \\
\text { pr. år (65-84) }\end{array}$ & $\begin{array}{r}\text { Antal diag- } \\
\text { nosticerede } \\
\text { patienter } \\
\text { med bipolar } \\
\text { lidelse, som } \\
\text { har haft } \\
\text { kontakt med } \\
\text { sekundær } \\
\text { sektor pr. } \\
100.000 \\
\text { indbyggere } \\
\text { pr. år (85+) }\end{array}$ \\
\hline Danmark & 89,5 & 51,8 & 86,1 & 103,5 & 93,4 & 55,4 \\
\hline Finland & 208,6 & 240,2 & 360,9 & 272,6 & 88,1 & 9,9 \\
\hline Færøerne & 60,2 & 20,3 & 34,7 & 149,0 & 99,4 & 72,3 \\
\hline Grønland & N/A & N/A & N/A & N/A & N/A & $\mathrm{N} / \mathrm{A}$ \\
\hline Island & N/A & N/A & N/A & N/A & N/A & $\mathrm{N} / \mathrm{A}$ \\
\hline Norge & 227,3 & 238,0 & 282,9 & 240,7 & 126,2 & 44,8 \\
\hline Sverige & 322,1 & 280,7 & 354,3 & 383,5 & 251,1 & 77,0 \\
\hline
\end{tabular}

Anm.: Finland og Færøerne har anvendt hele befolkningen. $\varnothing$ vrige lande har anvendt $18+$ befolkning Endvidere er aldersgruppen 18-24 år erstattet af 15-24 år for Finland. For Færøerne er tallene baseret på et gennemsnit for 2005-2009. Resultater fra Norge er overestimeret jf. indledende kommentarer.

Bemærkninger til tabel 2.5.3, tabel 2.5.4 og tabel 2.5.5:

Vedrørende diagnosticerede patienter med bipolar lidelse, så er resultater fra Færøerne ikke sammenlignelig med de $\varnothing$ vrige landes resultater pga. det begrænsede datagrundlag, jf. de indledende kommentarer. Resultat fra Finland for $18+$ befolkningen er ikke sammenlignelig med de $\varnothing$ vrige landes, da dette tal er for hele befolkningen. Sverige har med 264,0 pr. 100.000 indbyggere flest diagnosticerede patienter med bipolar lidelse, mens Danmark har signifikant færre med 76,3 pr. 100.000 indbyggere. Tendensen er den samme for Finland og Norge, når der ses på aldersfordelingen, idet der er flest diagnosticerede patienter med bipolar lidelse i aldersgruppen 25-44 år, mens Danmark og Sverige har flest i aldersgruppen 45-64 år.

Alle fire lande har færrest patienter i den ældste aldersgruppe. Danmark skiller sig ud fra de tre øvrige, da fordelingen på de forskellige aldersgrupper er signifikant mere jævn i Danmark end i de tre øvrige lande. Generelt er der flere diagnosticerede kvinderr med bipolar lidelse pr. 100.000 indbyggere end mænd. Endvidere er der færre diagnosticerede kvinder med bipolar lidelse pr. 100.000 i den yngste aldersgruppe i Danmark end i den ældste aldersgruppe.

Fordelingen på de forskellige aldersgrupper i Danmark er ikke så jævn for diagnosticerede mænd med bipolar lidelse som for de kvinder. Tallene for Færøerne er baseret på indlagte patienter. 
Tabel 2.5.6. Diagnosticerede patienter med bipolar lidelse og misbrugsdiagnose 2009 (Samlet) basisindikatorer

\begin{tabular}{|c|c|c|c|c|c|c|}
\hline Land & $\begin{array}{r}\text { Antal } \\
\text { diagnostice- } \\
\text { rede patien- } \\
\text { ter med } \\
\text { bipolar } \\
\text { lidelse og } \\
\text { misbrugsdi- } \\
\text { agnose, som } \\
\text { har haft } \\
\text { kontakt med } \\
\text { sekundær } \\
\text { sektor pr. } \\
100.000 \\
\text { indbyggere } \\
\text { pr. år (18+) }\end{array}$ & $\begin{array}{r}\text { Antal } \\
\text { diagnostice- } \\
\text { rede patien- } \\
\text { ter med } \\
\text { bipolar } \\
\text { lidelse og } \\
\text { misbrugsdi- } \\
\text { agnose, som } \\
\text { har haft } \\
\text { kontakt med } \\
\text { sekundær } \\
\text { sektor pr. } \\
100.000 \\
\text { indbyggere } \\
\text { pr. år (18- } \\
24)\end{array}$ & $\begin{array}{r}\text { Antal } \\
\text { diagnostice- } \\
\text { rede patien- } \\
\text { ter med } \\
\text { bipolar } \\
\text { lidelse og } \\
\text { misbrugsdi- } \\
\text { agnose, som } \\
\text { har haft } \\
\text { kontakt med } \\
\text { sekundær } \\
\text { sektor pr. } \\
100.000 \\
\text { indbyggere } \\
\text { pr. år (25- } \\
44)\end{array}$ & $\begin{array}{r}\text { Antal } \\
\text { diagnostice- } \\
\text { rede patien- } \\
\text { ter med } \\
\text { bipolar } \\
\text { lidelse og } \\
\text { misbrugsdi- } \\
\text { agnose, som } \\
\text { har haft } \\
\text { kontakt med } \\
\text { sekundær } \\
\text { sektor pr. } \\
100.000 \\
\text { indbyggere } \\
\text { pr. år (45- } \\
64)\end{array}$ & $\begin{array}{r}\text { Antal } \\
\text { diagnostice- } \\
\text { rede patien- } \\
\text { ter med } \\
\text { bipolar } \\
\text { lidelse og } \\
\text { misbrugsdi- } \\
\text { agnose, som } \\
\text { har haft } \\
\text { kontakt med } \\
\text { sekundær } \\
\text { sektor pr. } \\
100.000 \\
\text { indbyggere } \\
\text { pr. år (65- } \\
84)\end{array}$ & $\begin{array}{r}\text { Antal } \\
\text { diagnostice- } \\
\text { rede patien- } \\
\text { ter med } \\
\text { bipolar } \\
\text { lidelse og } \\
\text { misbrugsdi- } \\
\text { agnose, som } \\
\text { har haft } \\
\text { kontakt med } \\
\text { sekundær } \\
\text { sektor pr. } \\
100.000 \\
\text { indbyggere } \\
\text { pr. år }(85+)\end{array}$ \\
\hline Danmark & 11,7 & 4,8 & 11,1 & 18,8 & 5,1 & 0,0 \\
\hline Finland & 8,9 & 3,3 & 14,9 & 16,0 & 0,7 & 0,0 \\
\hline Færøerne & N/A & N/A & $\mathrm{N} / \mathrm{A}$ & N/A & N/A & N/A \\
\hline Grønland & N/A & N/A & N/A & N/A & N/A & N/A \\
\hline Island & N/A & N/A & $\mathrm{N} / \mathrm{A}$ & N/A & $\mathrm{N} / \mathrm{A}$ & $\mathrm{N} / \mathrm{A}$ \\
\hline Norge & 12,4 & 8,5 & 16,7 & 15,1 & 2,3 & 0,0 \\
\hline Sverige & 7,7 & 3,2 & 7,1 & 13,5 & 2,7 & 0,4 \\
\hline
\end{tabular}

Anm.: Finland har anvendt hele befolkningen. $\varnothing$ vrige lande har anvendt $18+$ befolkning Endvidere er aldersgruppen 18-24 år erstattet af 15-24 år for Finland. Resultater fra Norge er overestimeret jf. indledende kommentarer.

Tabel 2.5.7. Diagnosticerede patienter med bipolar lidelse 2009 og misbrugsdiagnose (Mænd) basisindikatorer

\begin{tabular}{|c|c|c|c|c|c|c|}
\hline Land & $\begin{array}{r}\text { Antal diag- } \\
\text { nosticerede } \\
\text { patienter } \\
\text { med bipolar } \\
\text { lidelse og } \\
\text { misbrugsdi- } \\
\text { agnose, som } \\
\text { har haft } \\
\text { kontakt med } \\
\text { sekundær } \\
\text { sektor pr. } \\
100.000 \\
\text { indbyggere } \\
\text { pr. år (18+) }\end{array}$ & $\begin{array}{r}\text { Antal diag- } \\
\text { nosticerede } \\
\text { patienter } \\
\text { med bipolar } \\
\text { lidelse og } \\
\text { misbrugsdi- } \\
\text { agnose, som } \\
\text { har haft } \\
\text { kontakt med } \\
\text { sekundær } \\
\text { sektor pr. } \\
100.000 \\
\text { indbyggere } \\
\text { pr. år (18-24) }\end{array}$ & $\begin{array}{r}\text { Antal diag- } \\
\text { nosticerede } \\
\text { patienter } \\
\text { med bipolar } \\
\text { lidelse og } \\
\text { misbrugsdi- } \\
\text { agnose, som } \\
\text { har haft } \\
\text { kontakt med } \\
\text { sekundær } \\
\text { sektor pr. } \\
100.000 \\
\text { indbyggere } \\
\text { pr. år (25-44) }\end{array}$ & $\begin{array}{r}\text { Antal diag- } \\
\text { nosticerede } \\
\text { patienter } \\
\text { med bipolar } \\
\text { lidelse og } \\
\text { misbrugsdi- } \\
\text { agnose, som } \\
\text { har haft } \\
\text { kontakt med } \\
\text { sekundær } \\
\text { sektor pr. } \\
100.000 \\
\text { indbyggere } \\
\text { pr. år (45-64) }\end{array}$ & $\begin{array}{r}\text { Antal diag- } \\
\text { nosticerede } \\
\text { patienter } \\
\text { med bipolar } \\
\text { lidelse og } \\
\text { misbrugsdi- } \\
\text { agnose, som } \\
\text { har haft } \\
\text { kontakt med } \\
\text { sekundær } \\
\text { sektor pr. } \\
100.000 \\
\text { indbyggere } \\
\text { pr. år (65-84) }\end{array}$ & $\begin{array}{r}\text { Antal diag- } \\
\text { nosticerede } \\
\text { patienter } \\
\text { med bipolar } \\
\text { lidelse og } \\
\text { misbrugsdi- } \\
\text { agnose, som } \\
\text { har haft } \\
\text { kontakt med } \\
\text { sekundær } \\
\text { sektor pr. } \\
100.000 \\
\text { indbyggere } \\
\text { pr. år (85+) }\end{array}$ \\
\hline Danmark & 13,8 & 6,5 & 14,1 & 20,9 & 4,2 & 0,0 \\
\hline Finland & 11,7 & 3,0 & 19,4 & 20,8 & 0,9 & 0,0 \\
\hline Færøerne & N/A & N/A & N/A & $\mathrm{N} / \mathrm{A}$ & N/A & N/A \\
\hline Grønland & N/A & $N / A$ & $\mathrm{~N} / \mathrm{A}$ & $\mathrm{N} / \mathrm{A}$ & N/A & N/A \\
\hline Island & N/A & N/A & N/A & N/A & N/A & N/A \\
\hline Norge & 15,5 & 6,5 & 20,7 & 19,1 & 2,9 & 0,0 \\
\hline Sverige & 9,5 & 2,1 & 8,7 & 16,8 & 3,9 & 0,0 \\
\hline
\end{tabular}

Anm.: Finland har anvendt hele befolkningen. $\varnothing$ vrige lande har anvendt $18+$ befolkning Endvidere er aldersgruppen 18-24 år erstattet af 15-24 år for Finland. Resultater fra Norge er overestimeret jf. indledende kommentarer. 
Tabel 2.5.8. Diagnosticerede patienter med bipolar lidelse og misbrugsdiagnose 2009 (Kvinder) basisindikatorer

\begin{tabular}{|c|c|c|c|c|c|c|}
\hline Land & $\begin{array}{r}\text { Antal } \\
\text { diagnostice- } \\
\text { rede patien- } \\
\text { ter med } \\
\text { bipolar } \\
\text { lidelse og } \\
\text { misbrugsdi- } \\
\text { agnose, som } \\
\text { har haft } \\
\text { kontakt med } \\
\text { sekundær } \\
\text { sektor pr. } \\
100.000 \\
\text { indbyggere } \\
\text { pr. år (18+) }\end{array}$ & $\begin{array}{r}\text { Antal } \\
\text { diagnostice- } \\
\text { rede patien- } \\
\text { ter med } \\
\text { bipolar } \\
\text { lidelse og } \\
\text { misbrugsdi- } \\
\text { agnose, som } \\
\text { har haft } \\
\text { kontakt med } \\
\text { sekundær } \\
\text { sektor pr. } \\
100.000 \\
\text { indbyggere } \\
\text { pr. år (18- } \\
24)\end{array}$ & $\begin{array}{r}\text { Antal } \\
\text { diagnostice- } \\
\text { rede patien- } \\
\text { ter med } \\
\text { bipolar } \\
\text { lidelse og } \\
\text { misbrugsdi- } \\
\text { agnose, som } \\
\text { har haft } \\
\text { kontakt med } \\
\text { sekundær } \\
\text { sektor pr. } \\
100.000 \\
\text { indbyggere } \\
\text { pr. år (25- } \\
44)\end{array}$ & $\begin{array}{r}\text { Antal } \\
\text { diagnostice- } \\
\text { rede patien- } \\
\text { ter med } \\
\text { bipolar } \\
\text { lidelse og } \\
\text { misbrugsdi- } \\
\text { agnose, som } \\
\text { har haft } \\
\text { kontakt med } \\
\text { sekundær } \\
\text { sektor pr. } \\
100.000 \\
\text { indbyggere } \\
\text { pr. år (45- } \\
64)\end{array}$ & $\begin{array}{r}\text { Antal } \\
\text { diagnostice- } \\
\text { rede patien- } \\
\text { ter med } \\
\text { bipolar } \\
\text { lidelse og } \\
\text { misbrugsdi- } \\
\text { agnose, som } \\
\text { har haft } \\
\text { kontakt med } \\
\text { sekundær } \\
\text { sektor pr. } \\
100.000 \\
\text { indbyggere } \\
\text { pr. år (65- } \\
84)\end{array}$ & $\begin{array}{r}\text { Antal } \\
\text { diagnostice- } \\
\text { rede patien- } \\
\text { ter med } \\
\text { bipolar } \\
\text { lidelse og } \\
\text { misbrugsdi- } \\
\text { agnose, som } \\
\text { har haft } \\
\text { kontakt med } \\
\text { sekundær } \\
\text { sektor pr. } \\
100.000 \\
\text { indbyggere } \\
\text { pr. år (85+) }\end{array}$ \\
\hline Danmark & 14,3 & 18,9 & 17,5 & 17,9 & 2,6 & 0,0 \\
\hline Finland & 1,6 & 0,9 & 3,0 & 2,3 & 0,7 & 0,0 \\
\hline Færøerne & N/A & $\mathrm{N} / \mathrm{A}$ & N/A & N/A & N/A & N/A \\
\hline Grønland & $\mathrm{N} / \mathrm{A}$ & N/A & N/A & N/A & N/A & N/A \\
\hline Island & N/A & $\mathrm{N} / \mathrm{A}$ & $\mathrm{N} / \mathrm{A}$ & $\mathrm{N} / \mathrm{A}$ & N/A & N/A \\
\hline Norge & 9,4 & 10,6 & 12,5 & 11,0 & 1,8 & 0,0 \\
\hline Sverige & 5,9 & 4,3 & 5,5 & 10,2 & 1,7 & 0,6 \\
\hline
\end{tabular}

Anm.: Finland har anvendt hele befolkningen. $\varnothing$ vrige lande har anvendt $18+$ befolkning Endvidere er aldersgruppen 18-24 år erstattet af 15-24 år for Finland. Resultater fra Norge er overestimeret jf. indledende kommentarer.

Bemærkninger til tabel 2.5.6, tabel 2.5.7 og 2.5.9:

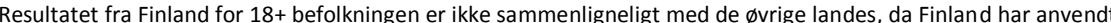
tal for hele befolkningen. Norge har med 12,4 pr. 100.000 indbyggere flest diagnosticerede patienter med bipolar lidelse og misbrugsdiagnose, mens Sverige har færrest med 7,7 pr. 100.000 indbyggere. Med undtagelse af Norge har landene flest pr. 100.000 indbyggere i aldersgruppen 45-64 år, mens Norge har flest i aldersgruppen 25-44 år. Generelt kan endvidere konkluderes, at der er flere mænd end kvinder der diagnosticeres med bipolar lidelse og misbrugsdiagnose, dog med undtagelse af Danmark, hvor det forholder sig omvendt. Endvidere er mændene generelt lidt ældre end kvinderne.

Tabel 2.5.9. Dødelighed for patienter med bipolar lidelse 2009 - basisindikatorer

\begin{tabular}{|c|c|c|c|}
\hline Land & $\begin{array}{l}\text { Andel självmord inom ett år för patienter } \\
\text { med kontakt med psykiatrin for bipolär } \\
\text { lidelse. Samtliga patienter som vårdats inom } \\
\text { specialiserad psykiatrisk vård (som inlagd } \\
\text { eller med läkarbesök i öppen vård) under ett } \\
\text { kalenderår (räknat från första besöksdatum } \\
\text { för året eller första inläggningsdagen vid } \\
\text { första inskrivningen) }\end{array}$ & $\begin{array}{r}\text { Antallet af dødsfald pr. } \\
10.000 \text { indbyggere med } \\
\text { bipolar lidelse der på et } \\
\text { eller andet tidspunkt } \\
\text { indenfor de sidste } 5 \text { år er } \\
\text { blevet behandlet for } \\
\text { bipolar lidelse ( } 20-59 \text { år) }\end{array}$ & $\begin{array}{r}\text { Antallet af } \\
\text { dødsfald i befolk- } \\
\text { ningen pr. } 10.000 \\
\text { indbyggere (20- } \\
59 \text { år) }\end{array}$ \\
\hline Danmark & $0,21 \%$ & 60,0 & 23,6 \\
\hline Finland & $0,0 \%$ & 342,2 & 24,5 \\
\hline Færøerne & $\mathrm{N} / \mathrm{A}$ & 104,2 & 17,3 \\
\hline Grønland & $\mathrm{N} / \mathrm{A}$ & N/A & N/A \\
\hline Island & $\mathrm{N} / \mathrm{A}$ & $\mathrm{N} / \mathrm{A}$ & N/A \\
\hline Norge & N/A & $\mathrm{N} / \mathrm{A}$ & N/A \\
\hline Sverige & $0,46 \%$ & 59,2 & 15,3 \\
\hline
\end{tabular}

Anm.: For selvmord gælder, at selvmordet er sket i 2009, men patienten kan have haft seneste kontakt med psykiatrisk afdeling i 2008.

Bemærkninger: Vedrørende selvmord indenfor 1 år for patienter med bipolar lidelse, har Sverige den største andel med 0,46 pct. mod Danmarks 0,21 pct., mens Finland ikke har selvmord indenfor gruppen. I forhold til antallet af $\mathrm{d} \varnothing \mathrm{d}$ sfald pr. 10.000 indbyggere, viser tabellen, at der er en større dødelighed for personer der indenfor de sidste 5 år er blevet behandlet for bipolar lidelse end befolkningen som helhed. Ud fra dette kan det konkluderes, at der er st $\varnothing$ rre sandsynlighed for $\mathrm{d} \emptyset \mathrm{dsfald}$, hvis man har eller for nyligt har været i behandling for bipolar lidelse. Sverige har 59,2 $\mathrm{d} \varnothing \mathrm{dsfald}$ pr. 10.000 for patienter med bipolar lidelse mod 15,3 dødsfald pr. 10.000 indbyggere i alt, mens Danmark for patienter med bipolar lidelse har $60 \mathrm{~d} \varnothing \mathrm{d}$ sfald pr.10.000 mod 23,6 dødsfald pr. 10.000 indbyggere i alt. Tallene for Færøerne er baseret på indlagte patienter. 
Tabel 2.5.10. Genindlæggelser for bipolar lidelse - kvalitetsindikatorer

\begin{tabular}{lrrr}
\hline Land & $\begin{array}{r}\text { Genindlæggelse på psykia- } \\
\text { trisk afdeling for bipolar } \\
\text { lidelse (14 til 28 dage) }\end{array}$ & $\begin{array}{r}\text { Genindlæggelse på psykia- } \\
\text { trisk afdeling for bipolar } \\
\text { lidelse (3 til 6 måneder) }\end{array}$ & $\begin{array}{r}\text { Uplanlagt bipolar lidelse } \\
\text { (samme hospital) genindlæg- } \\
\text { gelsesrate (2007) }\end{array}$ \\
\hline Danmark & $8,6 \%$ & $7,3 \%$ & 19,4 \\
Finland & $1,2 \%$ & $6,0 \%$ & 33,9 \\
Færøerne & $\mathrm{N} / \mathrm{A}$ & $\mathrm{N} / \mathrm{A}$ & $\mathrm{N} / \mathrm{A}$ \\
Grønland & $\mathrm{N} / \mathrm{A}$ & $\mathrm{N} / \mathrm{A}$ & $\mathrm{N} / \mathrm{A}$ \\
Island & $\mathrm{N} / \mathrm{A}$ & $\mathrm{N} / \mathrm{A}$ & $\mathrm{N} / \mathrm{A}$ \\
Norge & $6,6 \%$ & $5,2 \%$ & 18,4 \\
Sverige & $\mathrm{N} / \mathrm{A}$ & $\mathrm{N} / \mathrm{A}$ & 25,1 \\
\hline
\end{tabular}

Anm.: For Færøerne er tallene baseret på et gennemsnit for 2005-2009.

Bemærkninger: Pga. det begrænsede datagrundlag for Færøerne er disse resultater ikke sammenlignelige med de øvrige landes. Med hensyn til genindlæggelser på psykiatrisk afdeling for bipolar lidelse mellem 14 til 28 dage, så er der relativt flere i Danmark med 8,6 pct. i forhold til Norge med 6,6 pct. og Finland med 1,2 pct.. Det samme gør sig gældende for genindlæggelser mellem 3 og 6 måneder, hvor der $\mathrm{i}$ Danmark genindlægges 7,3 pct. mod 6,0 pct. og 5,2 pct. for hhv. Finland og Norge. For uplanlagte genindlæggelser på samme hospital, er der relativt flest i Finland med en andel på 33,9 pct., mens Norge har relativt færrest med 18,4 pct.

Tabel 2.5.11. Följsamhet till litiumbehandling, undvikbar somatisk slutenvård och återinskrivningar vid bipolärsjukdom - kvalitetsindikatorer

Sverige

Följsamhet till litiumbehandling vid bipolär sjukdom (antalet personer med uttag av litium på ～～83\% recept som fortsatt hämtat ut litum minst en gång

Undvikbar somatisk slutenvård efter vård inom psykiatrin pr. 100.000 indbyggere (Män) 1.468

Undvikbar somatisk slutenvård efter vård inom psykiatrin pr. 100.000 indbyggere (Kvinnor) $\quad 1.455$

Återinskrivning inom 14 dagar efter sluten vård för bipolär sjukdom $\quad 10 \%$

Återinskrivning inom 28 dagar efter sluten vård för bipolär sjukdom $\quad 15 \%$

Återinskrivning inom 3 månader $\quad 25 \%$

Återinskrivning inom 6 månader $\quad 34 \%$

Anm.: Data for undvikbara somatiska slutenvårdstillfällen efter vård inom psykiatrin er for 2008 och patienter mellan 20-59 år. Som undvikbar slutenvård räknas till exempel vård för diagnoserna astma, diabetes, hjärtsvikt och KOL En jämförelse görs också med en population utan tiidigare psykiatrisk vård.

Bemærkninger: Indikatorn undvikbar somatisk slutenvård ska belysa omhändertagandet vid vissa speicificerade sjukdomstillstånd inom den öppna vården, till exempel genom en fungerande primärvård och förebyggande folkhälsoarbete. Som undvikbar slutenvård räknas till exempel vård för diagnoserna astma, diabetes, hjärtsvikt och KOL. En jämförelse görs också med en population utan tidigare psykiatrisk vård.Tanken är att man kan förhindra onödiga inläggningar på sjukhus om patienter får ett bra omhändertagande i den öppna somatiska vården. För mera information om indikatorerna hänvisas till rapport http://www.socialstyrelsen.se/Lists/ Artikelkatalog/Attachments/18050/2010-6-6.pdf 


\subsection{ADHD (Attention Deficit/Hyperactivity Disorder)}

Tabel 2.6.1. Nydiagnosticerede patienter med ADHD - basisindikatorer

\begin{tabular}{|c|c|c|c|c|c|c|}
\hline Land & $\begin{array}{r}\text { Antal } \\
\text { nydiagno- } \\
\text { sticerede } \\
\text { patienter } \\
\text { med ADHD } \\
\text { med } \\
\text { kontakt til } \\
\text { sekundær } \\
\text { sektor pr. } \\
\text { år (Samlet) }\end{array}$ & $\begin{array}{r}\text { Samlet antal } \\
\text { nydiagnostice- } \\
\text { rede patienter } \\
\text { med ADHD } \\
\text { med kontakt } \\
\text { til sekundær } \\
\text { sektor pr. } \\
100.000 \\
\text { indbyggere pr. } \\
\text { år (Samlet) }\end{array}$ & $\begin{array}{r}\text { Antal } \\
\text { nydiagnosti- } \\
\text { cerede } \\
\text { patienter } \\
\text { med ADHD } \\
\text { med kon- } \\
\text { takt til } \\
\text { sekundær } \\
\text { sektor pr. år } \\
\text { (Mænd) }\end{array}$ & $\begin{array}{r}\text { Samlet antal } \\
\text { nydiagnosti- } \\
\text { cerede } \\
\text { patienter } \\
\text { med ADHD } \\
\text { med kontakt } \\
\text { til sekundær } \\
\text { sektor pr. } \\
100.000 \\
\text { indbyggere } \\
\text { pr. år (Mænd) }\end{array}$ & $\begin{array}{r}\text { Antal } \\
\text { nydiagno- } \\
\text { sticerede } \\
\text { patienter } \\
\text { med ADHD } \\
\text { med } \\
\text { kontakt til } \\
\text { sekundær } \\
\text { sektor pr. år } \\
\text { (Kvinder) }\end{array}$ & $\begin{array}{r}\text { Samlet antal } \\
\text { nydiagnostice- } \\
\text { rede patienter } \\
\text { med ADHD } \\
\text { med kontakt } \\
\text { til sekundær } \\
\text { sektor pr. } \\
100.000 \\
\text { indbyggere pr. } \\
\text { år (Kvinder) }\end{array}$ \\
\hline Danmark & 3.088 & 55,9 & 2.232 & 81,6 & 856 & 30,8 \\
\hline Finland & 1.039 & 19,4 & 766 & 29,2 & 273 & 10,0 \\
\hline Færøerne & 0,6 & 1,2 & 0,4 & 1,6 & 0,2 & 0,9 \\
\hline Grønland & N/A & N/A & $\mathrm{N} / \mathrm{A}$ & N/A & N/A & $\mathrm{N} / \mathrm{A}$ \\
\hline Island & N/A & $\mathrm{N} / \mathrm{A}$ & N/A & N/A & N/A & $\mathrm{N} / \mathrm{A}$ \\
\hline Norge & N/A & N/A & N/A & N/A & N/A & N/A \\
\hline Sverige & 14.383 & 195,0 & 9.536 & 262,0 & 4.847 & 129,7 \\
\hline
\end{tabular}

Anm.: For Færøerne er tallene baseret på et gennemsnit for 2005-2009. I Sverige er nydiagnosticerede beregnet som patienter, der ikke har haft en diagnose et år inden indskrivningsdato/bes øgsdato. Tallene for Finland er for indlagte patienter.

Bemærkninger: Resultaterne for nydiagnosticerede patienter med ADHD er ikke sammenlignelige. Færøerne har et lille datagrundlag jf. de indledende kommentarer. Sverige har beregnet nydiagnosticerede ud fra en anden definition, hvilket betyder at flere patienter indgår. Tallene fra Finland er for indlagte patienter. Generelt er der flere mænd end kvinder, der bliver nydiagnosticeret med ADHD. Tallene for Færøerne er baseret på indlagte patienter.

Tabel 2.6.2. Nydiagnosticerede patienter med ADHD og misbrugsdiagnose - basisindikatorer

\begin{tabular}{|c|c|c|c|c|c|c|}
\hline Land & $\begin{array}{r}\text { Antal } \\
\text { nydiagnosti- } \\
\text { cerede } \\
\text { patienter } \\
\text { med ADHD } \\
\text { og mis- } \\
\text { brugsdiag- } \\
\text { nose med } \\
\text { kontakt til } \\
\text { sekundær } \\
\text { sektor pr. år } \\
\text { (Samlet) }\end{array}$ & $\begin{array}{r}\text { Samlet antal } \\
\text { nydiagnosti- } \\
\text { cerede } \\
\text { patienter } \\
\text { med ADHD } \\
\text { og mis- } \\
\text { brugsdiag- } \\
\text { nose med } \\
\text { kontakt til } \\
\text { sekundær } \\
\text { sektor pr. } \\
100.000 \\
\text { indbyggere } \\
\text { pr. år } \\
\text { (Samlet) }\end{array}$ & $\begin{array}{r}\text { Antal } \\
\text { nydiagnosti- } \\
\text { cerede } \\
\text { patienter } \\
\text { med ADHD } \\
\text { og mis- } \\
\text { brugsdiag- } \\
\text { nose med } \\
\text { kontakt til } \\
\text { sekundær } \\
\text { sektor pr. år } \\
\text { (Mænd) }\end{array}$ & $\begin{array}{r}\text { Samlet antal } \\
\text { nydiagnosti- } \\
\text { cerede } \\
\text { patienter } \\
\text { med ADHD } \\
\text { og mis- } \\
\text { brugsdiag- } \\
\text { nose med } \\
\text { kontakt til } \\
\text { sekundær } \\
\text { sektor pr. } \\
100.000 \\
\text { indbyggere } \\
\text { pr. år } \\
\text { (Mænd) }\end{array}$ & $\begin{array}{r}\text { Antal } \\
\text { nydiagnosti- } \\
\text { cerede } \\
\text { patienter } \\
\text { med ADHD } \\
\text { og mis- } \\
\text { brugsdiag- } \\
\text { nose med } \\
\text { kontakt til } \\
\text { sekundær } \\
\text { sektor pr. år } \\
\text { (Kvinder) }\end{array}$ & $\begin{array}{r}\text { Samlet antal } \\
\text { nydiagnosti- } \\
\text { cerede } \\
\text { patienter } \\
\text { med ADHD } \\
\text { og mis- } \\
\text { brugsdiag- } \\
\text { nose med } \\
\text { kontakt til } \\
\text { sekundær } \\
\text { sektor pr } \\
100.000 \\
\text { indbyggere } \\
\text { pr. år } \\
\text { (Kvinder) }\end{array}$ \\
\hline Danmark & 229 & 4,1 & 184 & 6,7 & 45 & 1,6 \\
\hline Finland & 13 & 0,2 & 8 & 0,3 & 5 & 0,2 \\
\hline Færøerne & N/A & N/A & N/A & $\mathrm{N} / \mathrm{A}$ & $\mathrm{N} / \mathrm{A}$ & $\mathrm{N} / \mathrm{A}$ \\
\hline Grønland & $\mathrm{N} / \mathrm{A}$ & N/A & N/A & N/A & N/A & $\mathrm{N} / \mathrm{A}$ \\
\hline Island & N/A & N/A & N/A & $\mathrm{N} / \mathrm{A}$ & $\mathrm{N} / \mathrm{A}$ & $\mathrm{N} / \mathrm{A}$ \\
\hline Norge & N/A & N/A & N/A & N/A & $\mathrm{N} / \mathrm{A}$ & $\mathrm{N} / \mathrm{A}$ \\
\hline Sverige & 950 & 10,2 & 663 & 14,3 & 287 & 6,1 \\
\hline
\end{tabular}

Anm.: I Sverige er nydiagnosticerede beregnet som patienter, der ikke har haft en diagnose et år inden indskrivningsdato/bes $\varnothing$ gsdato. Tal fra Finland indeholder indlagte patienter og ikke ambulante.

Bemærkninger: Danmark, Finland og Sverige har opgivet tal for nydiagnosticerede patienter med ADHD og misbrugsdiagnose. Tallene ikke sammenlignelige. Sverige har anvendt en anden opg $\varnothing$ relsesmetode, og tallene for Finland er for indlagte patienter. Generelt for de tre lande er, at der er flere nydiagnosticere mænd end kvinder med bipolar lidelse og misbrugsdiagnose. 
Tabel 2.6.3. Diagnosticerede patienter med ADHD 2009 (Samlet) - basisindikatorer

\begin{tabular}{|c|c|c|c|c|c|}
\hline Land & $\begin{array}{r}\text { Antal diagno- } \\
\text { sticerede } \\
\text { patienter med } \\
\text { ADHD, som har } \\
\text { haft kontakt } \\
\text { med sekundær } \\
\text { sektor pr. } \\
100.000 \text { ind- } \\
\text { byggere pr. år } \\
\text { (Samlet) }\end{array}$ & $\begin{array}{r}\text { Antal diagno- } \\
\text { sticerede } \\
\text { patienter med } \\
\text { ADHD, som har } \\
\text { haft kontakt } \\
\text { med sekundær } \\
\text { sektor pr. } \\
100.000 \text { ind- } \\
\text { byggere pr. år } \\
(0-5)\end{array}$ & $\begin{array}{r}\text { Antal diagno- } \\
\text { sticerede } \\
\text { patienter med } \\
\text { ADHD, som har } \\
\text { haft kontakt } \\
\text { med sekundær } \\
\text { sektor pr. } \\
100.000 \text { ind- } \\
\text { byggere pr. år } \\
(6-17)\end{array}$ & $\begin{array}{r}\text { Antal diagno- } \\
\text { sticerede } \\
\text { patienter med } \\
\text { ADHD, som har } \\
\text { haft kontakt } \\
\text { med sekundær } \\
\text { sektor pr. } \\
100.000 \text { ind- } \\
\text { byggere pr. år } \\
(18-24)\end{array}$ & $\begin{array}{r}\text { Antal diagno- } \\
\text { sticerede } \\
\text { patienter med } \\
\text { ADHD, som har } \\
\text { haft kontakt } \\
\text { med sekundær } \\
\text { sektor pr. } \\
100.000 \text { ind- } \\
\text { byggere pr. år } \\
(25+)\end{array}$ \\
\hline Danmark & 88,3 & 66,5 & 377,6 & 158,9 & 20,4 \\
\hline Finland & 37,5 & & 109,2 & 119,9 & 16,9 \\
\hline Færøerne & 4,5 & 9,5 & 11,1 & 9,2 & 1,3 \\
\hline Grønland & $\mathrm{N} / \mathrm{A}$ & N/A & N/A & N/A & N/A \\
\hline Island & $\mathrm{N} / \mathrm{A}$ & N/A & $\mathrm{N} / \mathrm{A}$ & N/A & N/A \\
\hline Norge & 357,6 & 31,1 & $1.398,1$ & 652,7 & 118,1 \\
\hline Sverige & 245,2 & 35,9 & 848,1 & 507,3 & 113,6 \\
\hline
\end{tabular}

Anm.: For Finland er aldersgruppeinddelingen 6-15, 16-24 og 25+. For Færøerne er tallene baseret på et gennemsnit for 2005-2009. Resultater fra Norge er overestimeret jf. indledende kommentarer.

Bemærkning: Tallene for Færøerne er baseret på indlagte patienter.

Tabel 2.6.4. Diagnosticerede patienter med ADHD 2009 (Drenge/mænd) - basisindikatorer

\begin{tabular}{|c|c|c|c|c|c|}
\hline Land & $\begin{array}{r}\text { Antal diagno- } \\
\text { sticerede } \\
\text { patienter med } \\
\text { ADHD, som har } \\
\text { haft kontakt } \\
\text { med sekundær } \\
\text { sektor pr. } \\
100.000 \text { ind- } \\
\text { byggere pr. år } \\
\text { (Samlet) }\end{array}$ & $\begin{array}{r}\text { Antal diagno- } \\
\text { sticerede } \\
\text { patienter med } \\
\text { ADHD, som har } \\
\text { haft kontakt } \\
\text { med sekundær } \\
\text { sektor pr. } \\
100.000 \text { ind- } \\
\text { byggere pr. år } \\
(0-5)\end{array}$ & $\begin{array}{r}\text { Antal diagno- } \\
\text { sticerede } \\
\text { patienter med } \\
\text { ADHD, som har } \\
\text { haft kontakt } \\
\text { med sekundær } \\
\text { sektor pr. } \\
100.000 \text { ind- } \\
\text { byggere pr. år } \\
(6-17)\end{array}$ & $\begin{array}{r}\text { Antal diagno- } \\
\text { sticerede } \\
\text { patienter med } \\
\text { ADHD, som har } \\
\text { haft kontakt } \\
\text { med sekundær } \\
\text { sektor pr. } \\
100.000 \text { ind- } \\
\text { byggere pr. år } \\
(18-24)\end{array}$ & $\begin{array}{r}\text { Antal diagno- } \\
\text { sticerede } \\
\text { patienter med } \\
\text { ADHD, som har } \\
\text { haft kontakt } \\
\text { med sekundær } \\
\text { sektor pr. } \\
100.000 \text { ind- } \\
\text { byggere pr. år } \\
(25+)\end{array}$ \\
\hline Danmark & 130,6 & 103,4 & 563,4 & 214,1 & 26,3 \\
\hline Finland & 56,7 & & 186,2 & 171,9 & 21,7 \\
\hline Færøerne & 6,4 & 9,2 & 17,2 & 8,4 & 2,5 \\
\hline Grønland & N/A & N/A & N/A & N/A & $\mathrm{N} / \mathrm{A}$ \\
\hline Island & N/A & N/A & N/A & N/A & N/A \\
\hline Norge & 466,7 & 46,5 & $1.977,6$ & 663,5 & 129,7 \\
\hline Sverige & 329,0 & 51,7 & $1.254,7$ & 601,1 & 131,1 \\
\hline
\end{tabular}

Anm.: For Finland er aldersgruppe inddelingen 6-15, 16-24 og 25+. For Færøerne er tallene baseret på et gennemsnit for 2005-2009. Resultater fra Norge er overestimeret jf. indledende kommentarer. 
Tabel 2.6.5. Diagnosticerede patienter med ADHD 2009 (Piger/kvinder) - basisindikatorer

\begin{tabular}{|c|c|c|c|c|c|}
\hline Land & $\begin{array}{r}\text { Antal diagno- } \\
\text { sticerede } \\
\text { patienter med } \\
\text { ADHD, som har } \\
\text { haft kontakt } \\
\text { med sekundær } \\
\text { sektor pr. } \\
100.000 \text { ind- } \\
\text { byggere pr. år } \\
\text { (Samlet) }\end{array}$ & $\begin{array}{r}\text { Antal diagno- } \\
\text { sticerede } \\
\text { patienter med } \\
\text { ADHD, som har } \\
\text { haft kontakt } \\
\text { med sekundær } \\
\text { sektor pr. } \\
100.000 \text { ind- } \\
\text { byggere pr. år } \\
(0-5)\end{array}$ & $\begin{array}{r}\text { Antal diagno- } \\
\text { sticerede } \\
\text { patienter med } \\
\text { ADHD, som har } \\
\text { haft kontakt } \\
\text { med sekundær } \\
\text { sektor pr. } \\
100.000 \text { ind- } \\
\text { byggere pr. år } \\
(6-17)\end{array}$ & $\begin{array}{r}\text { Antal diagno- } \\
\text { sticerede } \\
\text { patienter med } \\
\text { ADHD, som har } \\
\text { haft kontakt } \\
\text { med sekundær } \\
\text { sektor pr. } \\
100.000 \text { ind- } \\
\text { byggere pr. år } \\
(18-24)\end{array}$ & $\begin{array}{r}\text { Antal diagno- } \\
\text { sticerede } \\
\text { patienter med } \\
\text { ADHD, som har } \\
\text { haft kontakt } \\
\text { med sekundær } \\
\text { sektor pr. } \\
100.000 \text { ind } \\
\text { byggere pr. år } \\
(25+)\end{array}$ \\
\hline Danmark & 46,7 & 27,7 & 182,4 & 101,3 & 14,7 \\
\hline Finland & 19,1 & & 29,0 & 65,5 & 12,4 \\
\hline Færøerne & 2,6 & 9,7 & 4,6 & 10,1 & 0,0 \\
\hline Grønland & $\mathrm{N} / \mathrm{A}$ & N/A & N/A & N/A & $\mathrm{N} / \mathrm{A}$ \\
\hline Island & $\mathrm{N} / \mathrm{A}$ & N/A & N/A & N/A & N/A \\
\hline Norge & 249,0 & 14,9 & 787,9 & 641,5 & 106,7 \\
\hline Sverige & 162,3 & 19,1 & 419,4 & 408,9 & 96,7 \\
\hline
\end{tabular}

Anm.: For Finland er aldersgruppe inddelingen 6-15, 16-24 og 25+. For Færøerne er tallene baseret på et gennemsnit for 2005-2009. Resultater fra Norge er overestimeret jf. indledende kommentarer.

Bemærkninger til tabel 2.6.3, tabel 2.6.4 og tabel 2.6.5:

Vedrørende diagnosticerede patienter med ADHD, så er resultater fra Færøerne ikke sammenlignelige med de $\emptyset$ vrige landes resultater pga. det begrænsede datagrundlag, jf. de indledende kommentarer. Norge har flest diagnosticerede patienter med ADHD med 357,6 pr. 100.000 indbyggere, mens Finland har færrest med 37,5 pr. 100.000 indbyggere. Resultaterne for Finland for de forskellige aldersgrupper med undtagelse af $25+$ er ikke sammenlignelige med de øvrige landes pga. en anden aldersgruppeinddeling.

For Danmark, Norge og Sverige gælder, at der er flest i aldersgruppen 6-17 år, mens der for Norge og Sverige er færrest i aldersgruppen 0-5 år. I Danmark er der færrest i den ældste aldersgruppe. Generelt er der signifikant flere drenge/mænd end piger/kvinder pr. 100.000 indbyggere med ADHD. Tallene for Færøerne er baseret på indlagte patienter.

Tabel 2.6.6. Diagnosticerede patienter med ADHD og misbrugsdiagnose 2009 (Samlet) - basisindikatorer

\begin{tabular}{|c|c|c|c|c|c|}
\hline Land & $\begin{array}{r}\text { Antal diagnostice- } \\
\text { rede patienter } \\
\text { med ADHD og } \\
\text { misbrugsdiagnose, } \\
\text { som har haft } \\
\text { kontakt med } \\
\text { sekundær sektor } \\
\text { pr. 100.000 } \\
\text { indbyggere pr. år } \\
\text { (Samlet) }\end{array}$ & $\begin{array}{r}\text { Antal diagnostice- } \\
\text { rede patienter } \\
\text { med ADHD og } \\
\text { misbrugsdiagnose, } \\
\text { som har haft } \\
\text { kontakt med } \\
\text { sekundær sektor } \\
\text { pr. 100.000 } \\
\text { indbyggere pr. år } \\
(0-5)\end{array}$ & $\begin{array}{r}\text { Antal diagnostice- } \\
\text { rede patienter } \\
\text { med ADHD og } \\
\text { misbrugsdiagnose, } \\
\text { som har haft } \\
\text { kontakt med } \\
\text { sekundær sektor } \\
\text { pr. 100.000 } \\
\text { indbyggere pr. år } \\
(6-17)\end{array}$ & $\begin{array}{r}\text { Antal diagnostice- } \\
\text { rede patienter } \\
\text { med ADHD og } \\
\text { misbrugsdiagnose, } \\
\text { som har haft } \\
\text { kontakt med } \\
\text { sekundær sektor } \\
\text { pr. 100.000 } \\
\text { indbyggere pr. år } \\
(18-24)\end{array}$ & $\begin{array}{r}\text { Antal diagnostice- } \\
\text { rede patienter } \\
\text { med ADHD og } \\
\text { misbrugsdiagnose, } \\
\text { som har haft } \\
\text { kontakt med } \\
\text { sekundær sektor } \\
\text { pr. 100.000 } \\
\text { indbyggere pr. år } \\
(25+)\end{array}$ \\
\hline Danmark & 6,5 & 0,0 & 4,6 & 27,5 & 5,1 \\
\hline Finland & 0,4 & & 0,2 & 0,5 & 0,4 \\
\hline Færøerne & $\mathrm{N} / \mathrm{A}$ & N/A & N/A & $\mathrm{N} / \mathrm{A}$ & N/A \\
\hline Grønland & N/A & N/A & $\mathrm{N} / \mathrm{A}$ & $\mathrm{N} / \mathrm{A}$ & N/A \\
\hline Island & $N / A$ & N/A & $\mathrm{N} / \mathrm{A}$ & N/A & $\mathrm{N} / \mathrm{A}$ \\
\hline Norge & 13,2 & 0,0 & 2,9 & 45,0 & 12,9 \\
\hline Sverige & 13,0 & 0,0 & 1,6 & 30,7 & 14,2 \\
\hline
\end{tabular}

Anm.: For Finland er aldersgruppe inddelingen 6-15, 16-24 og 25+. Resultater fra Norge er overestimeret jf. indledende kommentarer. 
Tabel 2.6.7. Diagnosticerede patienter med ADHD 2009 og misbrugsdiagnose (Drenge/mænd) - basisindikatorer

\begin{tabular}{|c|c|c|c|c|c|}
\hline Land & $\begin{array}{r}\text { Antal diagnostice- } \\
\text { rede patienter } \\
\text { med ADHD og } \\
\text { misbrugsdiagnose, } \\
\text { som har haft } \\
\text { kontakt med } \\
\text { sekundær sektor } \\
\text { pr. } 100.000 \\
\text { indbyggere pr. år } \\
\text { (Samlet) }\end{array}$ & $\begin{array}{r}\text { Antal diagnostice- } \\
\text { rede patienter } \\
\text { med ADHD og } \\
\text { misbrugsdiagnose, } \\
\text { som har haft } \\
\text { kontakt med } \\
\text { sekundær sektor } \\
\text { pr. } 100.000 \\
\text { indbyggere pr. år } \\
(0-5)\end{array}$ & $\begin{array}{r}\text { Antal diagnostice- } \\
\text { rede patienter } \\
\text { med ADHD og } \\
\text { misbrugsdiagnose, } \\
\text { som har haft } \\
\text { kontakt med } \\
\text { sekundær sektor } \\
\text { pr. 100.000 } \\
\text { indbyggere pr. år } \\
(6-17)\end{array}$ & $\begin{array}{r}\text { Antal diagnostice- } \\
\text { rede patienter } \\
\text { med ADHD og } \\
\text { misbrugsdiagnose, } \\
\text { som har haft } \\
\text { kontakt med } \\
\text { sekundær sektor } \\
\text { pr. 100.000 } \\
\text { indbyggere pr. år } \\
(18-24)\end{array}$ & $\begin{array}{r}\text { Antal diagnostice- } \\
\text { rede patienter } \\
\text { med ADHD og } \\
\text { misbrugsdiagnose, } \\
\text { som har haft } \\
\text { kontakt med } \\
\text { sekundær sektor } \\
\text { pr. } 100.000 \\
\text { indbyggere pr. år } \\
(25+)\end{array}$ \\
\hline Danmark & 10,5 & 0,0 & 7,1 & 45,2 & 8,1 \\
\hline Finland & 0,5 & & 0,0 & 1,0 & 0,5 \\
\hline Færøerne & N/A & N/A & N/A & N/A & N/A \\
\hline Grønland & N/A & N/A & N/A & N/A & N/A \\
\hline Island & N/A & N/A & N/A & N/A & N/A \\
\hline Norge & 19,3 & 0,0 & 3,7 & 57,4 & 20,1 \\
\hline Sverige & 18,4 & 0,0 & 1,1 & 38,8 & 21,1 \\
\hline
\end{tabular}

Anm.: For Finland er aldersgruppe inddelingen 6-15, 16-24 og 25+. Resultater fra Norge er overestimeret jf. indledende kommentarer.

Tabel 2.6.8. Diagnosticerede patienter med ADHD og misbrugsdiagnose 2009 (Piger/kvinder) - basisindikatorer

\begin{tabular}{|c|c|c|c|c|c|}
\hline Land & $\begin{array}{r}\text { Antal diagnostice- } \\
\text { rede patienter } \\
\text { med ADHD og } \\
\text { misbrugsdiagnose, } \\
\text { som har haft } \\
\text { kontakt med } \\
\text { sekundær sektor } \\
\text { pr. } 100.000 \\
\text { indbyggere pr. år } \\
\text { (Samlet) }\end{array}$ & $\begin{array}{r}\text { Antal diagnostice- } \\
\text { rede patienter } \\
\text { med ADHD og } \\
\text { misbrugsdiagnose, } \\
\text { som har haft } \\
\text { kontakt med } \\
\text { sekundær sektor } \\
\text { pr. } 100.000 \\
\text { indbyggere pr. år } \\
(0-5)\end{array}$ & $\begin{array}{r}\text { Antal diagnostice- } \\
\text { rede patienter } \\
\text { med ADHD og } \\
\text { misbrugsdiagnose, } \\
\text { som har haft } \\
\text { kontakt med } \\
\text { sekundær sektor } \\
\text { pr. 100.000 } \\
\text { indbyggere pr. år } \\
(6-17)\end{array}$ & $\begin{array}{r}\text { Antal diagnostice- } \\
\text { rede patienter } \\
\text { med ADHD og } \\
\text { misbrugsdiagnose, } \\
\text { som har haft } \\
\text { kontakt med } \\
\text { sekundær sektor } \\
\text { pr. 100.000 } \\
\text { indbyggere pr. år } \\
(18-24)\end{array}$ & $\begin{array}{r}\text { Antal diagnostice- } \\
\text { rede patienter } \\
\text { med ADHD og } \\
\text { misbrugsdiagnose, } \\
\text { som har haft } \\
\text { kontakt med } \\
\text { sekundær sektor } \\
\text { pr. } 100.000 \\
\text { indbyggere pr. år } \\
(25+)\end{array}$ \\
\hline Danmark & 2,6 & 0,0 & 2,0 & 9,0 & 2,3 \\
\hline Finland & 0,2 & & 0,3 & 0,0 & 0,3 \\
\hline Færøerne & N/A & N/A & N/A & N/A & N/A \\
\hline Grønland & $N / A$ & N/A & N/A & $N / A$ & $\mathrm{~N} / \mathrm{A}$ \\
\hline Island & N/A & N/A & N/A & N/A & N/A \\
\hline Norge & 7,1 & 0,0 & 2,2 & 31,9 & 5,8 \\
\hline Sverige & 7,6 & 0,0 & 2,1 & 22,3 & 7,5 \\
\hline
\end{tabular}

Anm.: For Finland er aldersgruppe inddelingen 6-15, 16-24 og 25+. Resultater fra Norge er overestimeret jf. indledende kommentarer.

Bemærkninger til tabel 2.6.6, tabel 2.6.7 og tabel 2.6.8:

Resultaterne for diagnosticerede patienter med ADHD og misbrugsdiagnose viser, at der er flest i Norge og Sverige med hhv. 13,2 og 13,0 pr. 100.000 indbyggere, mens der er signifikant færre i Finland med 0,4 pr. 100.000 indbyggere. Danmark har 6,5 pr. 100.000 indbyggere. Resultaterne for Finland for de forskellige aldersgrupper med undtagelse af $25+$ er ikke sammenlignelige med de øvrige landes pga. en anden aldersgruppeinddeling.

Tendensen er, at der er flest pr. 100.000 i aldersgruppen 18-24 for alle landene. Der er for alle landene ingen i den yngste aldersgruppe 0-5 år. Generelt er der flere drenge/mænd diagnosticeret med ADHD og misbrugsdiagnose end piger/kvinder. Der er flere piger/kvinder diagnosticeret med ADHD og misbrugsdiagnose i Sverige end i Norge, i mens det forholder sig omvendt for drenge/mænd. 
Tabel 2.6.9. Patientforløb og selvmord - ADHD - basisindikatorer

\begin{tabular}{lrr}
\hline Land & $\begin{array}{c}\text { Antal patientfor- } \\
\text { løb med ADHD }\end{array}$ & $\begin{array}{r}\text { Andel självmord inom ett år för patienter med kontakt med psykia- } \\
\text { trin for ADHD. Samtliga patienter som vårdats inom specialiserad } \\
\text { psykiatrisk vård (som inlagd eller med läkarbesök i öppen vård) } \\
\text { under ett kalenderår (räknat från första besöksdatum för året eller } \\
\text { första inläggningsdagen vid första inskrivningen). }\end{array}$ \\
\hline Danmark & N/A & $0,04 \%$ \\
Finland & N/A & $0,00 \%$ \\
Færøerne & N/A & N/A \\
Grønland & N/A & N/A \\
Island & N/A & N/A \\
Norge & N/A & \\
Sverige & N/A & \\
\hline
\end{tabular}

Anm.: For selvmord gælder, at selvmordet er sket i 2009, men patienten kan have haft seneste kontakt med psykiatrisk afdeling i 2008.

Bemærkninger:

Danmark har den største andel med 0,04 pct. for selvmord indenfor 1 år efter indskrivning for patienter med ADHD

\subsection{Generiske kvalitetsindikatorer}

Tabel 2.7.1. Psykiatriske patienter i behandling 2009 (Samlet) - basisindikatorer

\begin{tabular}{|c|c|c|c|c|c|c|c|}
\hline Land & $\begin{array}{r}\text { Antal } \\
\text { psykiatri- } \\
\text { ske } \\
\text { patienter } \\
\text { som er i } \\
\text { behand- } \\
\text { ling i } \\
\text { sekundær } \\
\text { sektor pr. } \\
100.000 \\
\text { indbygge- } \\
\text { re } \\
\text { (Samlet) }\end{array}$ & $\begin{array}{r}\text { Antal } \\
\text { psykiatri- } \\
\text { ske } \\
\text { patienter } \\
\text { som er i } \\
\text { behand- } \\
\text { ling i } \\
\text { sekundær } \\
\text { sektor pr. } \\
100.000 \\
\text { indbygge- } \\
\text { re (0-17) }\end{array}$ & $\begin{array}{r}\text { Antal } \\
\text { psykiatri- } \\
\text { ske } \\
\text { patienter } \\
\text { som er i } \\
\text { behand- } \\
\text { ling i } \\
\text { sekundær } \\
\text { sektor pr. } \\
100.000 \\
\text { indbygge- } \\
\text { re (18-24) }\end{array}$ & $\begin{array}{r}\text { Antal } \\
\text { psykiatri- } \\
\text { ske } \\
\text { patienter } \\
\text { som er i } \\
\text { behand- } \\
\text { ling i } \\
\text { sekundær } \\
\text { sektor pr. } \\
100.000 \\
\text { indbygge- } \\
\text { re (25-44) }\end{array}$ & $\begin{array}{r}\text { Antal } \\
\text { psykiatri- } \\
\text { ske } \\
\text { patienter } \\
\text { som er i } \\
\text { behand- } \\
\text { ling i } \\
\text { sekundær } \\
\text { sektor pr. } \\
100.000 \\
\text { indbygge- } \\
\text { re (45-64) }\end{array}$ & $\begin{array}{r}\text { Antal } \\
\text { psykiatri- } \\
\text { ske } \\
\text { patienter } \\
\text { som er i } \\
\text { behand- } \\
\text { ling i } \\
\text { sekundær } \\
\text { sektor pr. } \\
100.000 \\
\text { indbygge- } \\
\text { re (65-84) }\end{array}$ & $\begin{array}{r}\text { Antal } \\
\text { psykiatri- } \\
\text { ske } \\
\text { patienter } \\
\text { som er i } \\
\text { behand- } \\
\text { ling i } \\
\text { sekundær } \\
\text { sektor pr. } \\
100.000 \\
\text { indbygge- } \\
\text { re (85+) }\end{array}$ \\
\hline Danmark & $1.166,2$ & 892,7 & $1.870,8$ & $1.359,3$ & 939,9 & $1.048,0$ & 2.587 \\
\hline Finland & $2.481,5$ & & $4.327,3$ & $3.331,0$ & $2.715,8$ & 1366,6 & 907,3 \\
\hline Færøerne & 630,0 & 317,4 & 731,4 & 609,5 & 904,2 & 729,3 & 852,5 \\
\hline Grønland & N/A & N/A & N/A & N/A & N/A & N/A & N/A \\
\hline Island & $\mathrm{N} / \mathrm{A}$ & N/A & N/A & N/A & N/A & N/A & $\mathrm{N} / \mathrm{A}$ \\
\hline Norge & $3.568,1$ & $4.319,5$ & $5.608,2$ & $4.126,5$ & $2.669,6$ & $1.605,1$ & $1.979,6$ \\
\hline Sverige & $2.857,6$ & $1.886,9$ & $3.837,5$ & $3.468,2$ & $3.205,2$ & $2.084,6$ & $2.029,7$ \\
\hline
\end{tabular}

Anm.: Aldersgruppen 18-24 år er erstattet af 15-24 år for Finland. For Færøerne er tallene baseret på et gennemsnit for 2005-2009.

Bemærkning: Tallene for Færøerne er baseret på indlagte patienter. 
Tabel 2.7.2. Psykiatriske patienter i behandling 2009 (Mænd) - basisindikatorer

\begin{tabular}{|c|c|c|c|c|c|c|c|}
\hline Land & $\begin{array}{r}\text { Antal } \\
\text { psykiatri- } \\
\text { ske } \\
\text { patienter } \\
\text { som er i } \\
\text { behand- } \\
\text { ling i } \\
\text { sekundær } \\
\text { sektor pr. } \\
100.000 \\
\text { indbygge- } \\
\text { re } \\
\text { (Samlet) }\end{array}$ & $\begin{array}{r}\text { Antal } \\
\text { psykiatri- } \\
\text { ske } \\
\text { patienter } \\
\text { som er i } \\
\text { behand- } \\
\text { ling i } \\
\text { sekundær } \\
\text { sektor pr. } \\
100.000 \\
\text { indbygge- } \\
\text { re (0-17) }\end{array}$ & $\begin{array}{r}\text { Antal } \\
\text { psykiatri- } \\
\text { ske } \\
\text { patienter } \\
\text { som er i } \\
\text { behand- } \\
\text { ling i } \\
\text { sekundær } \\
\text { sektor pr. } \\
\text { 100.000 } \\
\text { indbygge- } \\
\text { re (18-24) }\end{array}$ & $\begin{array}{r}\text { Antal } \\
\text { psykiatri- } \\
\text { ske } \\
\text { patienter } \\
\text { som er i } \\
\text { behand- } \\
\text { ling i } \\
\text { sekundær } \\
\text { sektor pr. } \\
\text { 100.000 } \\
\text { indbygge- } \\
\text { re (25-44) }\end{array}$ & $\begin{array}{r}\text { Antal } \\
\text { psykiatri- } \\
\text { ske } \\
\text { patienter } \\
\text { som er i } \\
\text { behand- } \\
\text { ling i } \\
\text { sekundær } \\
\text { sektor pr. } \\
\text { 100.000 } \\
\text { indbygge- } \\
\text { re (45-64) }\end{array}$ & $\begin{array}{r}\text { Antal } \\
\text { psykiatri- } \\
\text { ske } \\
\text { patienter } \\
\text { som er i } \\
\text { behand- } \\
\text { ling i } \\
\text { sekundær } \\
\text { sektor pr. } \\
100.000 \\
\text { indbygge- } \\
\text { re (65-84) }\end{array}$ & $\begin{array}{r}\text { Antal } \\
\text { psykiatri- } \\
\text { ske } \\
\text { patienter } \\
\text { som er i } \\
\text { behand- } \\
\text { ling i } \\
\text { sekundær } \\
\text { sektor pr. } \\
100.000 \\
\text { indbygge- } \\
\text { re (85+) }\end{array}$ \\
\hline Danmark & $1.112,5$ & $2.056,4$ & $1.512,8$ & $1.276,2$ & 927,8 & 879,5 & $2.370,4$ \\
\hline Finland & $2.105,2$ & & $3.224,3$ & $2.896,2$ & $2.310,8$ & $1.098,3$ & 878,6 \\
\hline Færøerne & 708,8 & 376,0 & 707,7 & 715,2 & 998,0 & 998,0 & 754,5 \\
\hline Grønland & N/A & N/A & N/A & N/A & N/A & N/A & N/A \\
\hline Island & N/A & N/A & $\mathrm{N} / \mathrm{A}$ & N/A & N/A & $\mathrm{N} / \mathrm{A}$ & $\mathrm{N} / \mathrm{A}$ \\
\hline Norge & $3.393,7$ & $4.965,0$ & $4.427,9$ & $3.619,0$ & $2.332,9$ & $1.326,2$ & $1.985,8$ \\
\hline Sverige & $2.757,9$ & $2.187,0$ & $3.288,1$ & $3.151,1$ & $3.121,9$ & $1.942,6$ & $1.985,5$ \\
\hline
\end{tabular}

Anm.: Aldersgruppen 18-24 år er erstattet af 15-24 år for Finland. For Færøerne er tallene baseret på et gennemsnit for 2005-2009.

Bemærkning: Tallene for Færøerne er baseret på indlagte patienter.

Tabel 2.7.3. Psykiatriske patienter i behandling 2009 (Kvinder) - basisindikatorer

\begin{tabular}{|c|c|c|c|c|c|c|c|}
\hline Land & $\begin{array}{r}\text { Antal } \\
\text { psykia- } \\
\text { triske } \\
\text { patienter } \\
\text { som er i } \\
\text { behand- } \\
\text { ling i } \\
\text { sekun- } \\
\text { dær } \\
\text { sektor } \\
\text { pr. } \\
100.000 \\
\text { indbyg- } \\
\text { gere } \\
\text { (Samlet) }\end{array}$ & $\begin{array}{r}\text { Antal } \\
\text { psykiatri- } \\
\text { ske } \\
\text { patienter } \\
\text { som er i } \\
\text { behand- } \\
\text { ling i } \\
\text { sekundær } \\
\text { sektor pr. } \\
100.000 \\
\text { indbygge- } \\
\text { re (0-17) }\end{array}$ & $\begin{array}{r}\text { Antal } \\
\text { psykiatri- } \\
\text { ske } \\
\text { patienter } \\
\text { som er i } \\
\text { behand- } \\
\text { ling i } \\
\text { sekundær } \\
\text { sektor pr. } \\
100.000 \\
\text { indbygge- } \\
\text { re (18-24) }\end{array}$ & $\begin{array}{r}\text { Antal } \\
\text { psykiatri- } \\
\text { ske } \\
\text { patienter } \\
\text { som er i } \\
\text { behand- } \\
\text { ling i } \\
\text { sekundær } \\
\text { sektor pr. } \\
100.000 \\
\text { indbygge- } \\
\text { re (25-44) }\end{array}$ & $\begin{array}{r}\text { Antal } \\
\text { psykiatri- } \\
\text { ske } \\
\text { patienter } \\
\text { som er i } \\
\text { behand- } \\
\text { ling i } \\
\text { sekundær } \\
\text { sektor pr. } \\
100.000 \\
\text { indbygge- } \\
\text { re (45-64) }\end{array}$ & $\begin{array}{r}\text { Antal } \\
\text { psykiatri- } \\
\text { ske } \\
\text { patienter } \\
\text { som er i } \\
\text { behand- } \\
\text { ling i } \\
\text { sekundær } \\
\text { sektor pr. } \\
100.000 \\
\text { indbygge- } \\
\text { re (65-84) }\end{array}$ & $\begin{array}{r}\text { Antal } \\
\text { psykiatri- } \\
\text { ske } \\
\text { patienter } \\
\text { som er i } \\
\text { behand- } \\
\text { ling i } \\
\text { sekundær } \\
\text { sektor pr. } \\
100.000 \\
\text { indbygge- } \\
\text { re }(85+)\end{array}$ \\
\hline Danmark & $1.218,9$ & 720,7 & $2.244,9$ & $1.444,5$ & 952,0 & $1.191,7$ & $2.681,2$ \\
\hline Finland & $2.843,8$ & & $5.465,0$ & $3.786,8$ & $3.114,1$ & $1.574,7$ & 917,3 \\
\hline Færøerne & 544,8 & 255,3 & 759,9 & 485,5 & 799,7 & 603,2 & 904,2 \\
\hline Grønland & N/A & N/A & N/A & N/A & N/A & N/A & N/A \\
\hline Island & N/A & N/A & N/A & N/A & N/A & N/A & N/A \\
\hline Norge & $3.738,8$ & $3.628,5$ & $6.839,9$ & $4.656,7$ & $3.017,9$ & $1.837,9$ & $1.977,0$ \\
\hline Sverige & $2.956,3$ & $1.570,2$ & $4.414,3$ & $3.798,4$ & $3.289,9$ & $2.207,5$ & $2.051,5$ \\
\hline
\end{tabular}

Anm.: Aldersgruppen 18-24 år erstattet af 15-24 år for Finland. For Færøerne er tallene baseret på et gennemsnit for 2005-2009.

Bemærkninger til tabel 2.7.1, tabel 2.7.2 og tabel 2.7.3:

Resultater fra Færøerne er ikke sammenlignelige med de øvrige landes resultater pga. det begrænsede datagrundlag, jf. de indledende kommentarer. Norge har flest psykiatriske patienter i behandling pr. 100.000 med 3.568,1, mens Danmark har signifikant færre med 1.166,2 pr. 100.000 indbyggere. De sammenlignelige lande har med undtagelse af Danmark flest pr. 100.000 i aldersgruppen 18-24, mens Danmark har flest i den ældste aldersgruppe. Danmark har færrest pr. 100.000 i den yngste aldersgruppe, mens Norge har færrest i aldersgruppen 65-84. Sverige og Finland har den mindste tæthed af psykiatriske patienter i behandling i den ældste aldersgruppe. Tabellerne viser endvidere, at alle de sammenlignelige lande har flere kvinder i behandling end mænd. Endvidere er aldersfordeling på kvinder og mænd forskellig i Danmark og Norge, hvor der er relativt flere drenge/mænd end piger/kvinder i den yngste aldersgruppe. Tallene for Færøerne er baseret på indlagte patienter. 
Tabel 2.7.4. Relevante fagpersoner - basisindikatorer

\begin{tabular}{lrrrr}
\hline Land & $\begin{array}{r}\text { Antallet af relevante } \\
\text { fagpersoner pr. } \\
\mathbf{1 0 0 . 0 0 0 ~ i n d b y g g e r e} \\
\text { (psykiatere) (2005) }\end{array}$ & $\begin{array}{r}\text { Antallet af relevante } \\
\text { fagpersoner pr. } \\
\mathbf{1 0 0 . 0 0 0} \text { indbyggere } \\
\text { (psykiatriske syge- } \\
\text { plejersker) (2005) }\end{array}$ & $\begin{array}{r}\text { Antallet af relevante } \\
\text { fagpersoner pr. } \\
\mathbf{1 0 0 . 0 0 0 ~ i n d b y g g e r e ~} \\
\text { (psykologer) (2005) }\end{array}$ & $\begin{array}{r}\text { Antallet af relevante } \\
\text { fagpersoner pr. } \\
\mathbf{1 0 0 . 0 0 0 ~ i n d b y g g e r e ~} \\
\text { (børne- og ungepsy- } \\
\text { kiatere) (2003) }\end{array}$ \\
\hline Danmark & 16 & 59 & 85 & 3 \\
Finland & 22 & 180 & 79 & 4 \\
Færøerne & $\mathrm{N} / \mathrm{A}$ & 24,8 & $\mathrm{~N} / \mathrm{A}$ & $\mathrm{N} / \mathrm{A}$ \\
Grønland & 7,1 & 33 & 60 & N/A \\
Island & 25 & 42 & 68 & 2,1 \\
Norge & 20 & 32 & 76 & N/A \\
Sverige & 20 & & 3,5 \\
\hline
\end{tabular}

Anm.: Data for Grønland er for 2010. Ø $\varnothing$ vrige landes tal stammer fra Nomesco.

Bemærkninger:

Resultater fra Grønland og Island er ikke sammenlignelige med de øvrige landes resultater pga. det begrænsede datagrundlag, jf. de indledende kommentarer. Resultaterne fra de $\varnothing v$ rige lande viser, at antallet af psykiatere ikke er signifikant forskellige. Danmark har færrest psykiatere med 16 pr. 100.000 indbyggere, mens Finland har flest med 22 pr. 100.000 indbyggere. Finland har signifikant flere psykiatriske sygeplejersker med 16 pr. 100.000 indbyggere end de $\varnothing$ vrige lande. Sverige har færrest med 32 pr. 100.000 indbyggere. Danmark har flest psykologer pr. 100.000 med 85, mens Norge har færrest med 68 pr. 100.000 indbyggere.

For børne- og ungepsykiatere har landene ikke signifikante forskelle, idet Danmark som det land med færrest har 3 pr. 100.000 indbyggere, mens Finland som det land med flest har 4 pr. 100.000 indbyggere.

Tabel 2.7.5. Selvmord 2009 (Samlet) - basisindikatorer

\begin{tabular}{|c|c|c|c|c|c|c|c|}
\hline Land & $\begin{array}{r}\text { Antal } \\
\text { selvmord } \\
\text { under } \\
\text { indlæg- } \\
\text { gelser på } \\
\text { psykia- } \\
\text { trisk } \\
\text { sygehus } \\
\text { eller } \\
\text { afdeling } \\
\text { pr. } \\
\text { 100.000 } \\
\text { indbygge- } \\
\text { re }\end{array}$ & $\begin{array}{r}\text { Psykiatri- } \\
\text { ske } \\
\text { patienter, } \\
\text { der er } \\
\text { døde som } \\
\text { følge af } \\
\text { selvmord } \\
\text { pr. } \\
100.000 \\
\text { indbygge- } \\
\text { re inden- } \\
\text { for } 1 \text { år } \\
(18+)\end{array}$ & $\begin{array}{r}\text { Psykiatri- } \\
\text { ske } \\
\text { patienter, } \\
\text { der er } \\
\text { døde som } \\
\text { følge af } \\
\text { selvmord } \\
\text { pr. } \\
100.000 \\
\text { indbygge- } \\
\text { re inden- } \\
\text { for } 1 \text { år } \\
(18-24)\end{array}$ & $\begin{array}{r}\text { Psykiatri- } \\
\text { ske } \\
\text { patienter, } \\
\text { der er } \\
\text { døde som } \\
\text { følge af } \\
\text { selvmord } \\
\text { pr. } \\
100.000 \\
\text { indbygge- } \\
\text { re inden- } \\
\text { for } 1 \text { år } \\
\text { (25-44) }\end{array}$ & $\begin{array}{r}\text { Psykiatri- } \\
\text { ske } \\
\text { patienter, } \\
\text { der er } \\
\text { døde som } \\
\text { følge af } \\
\text { selvmord } \\
\text { pr. } \\
100.000 \\
\text { indbygge- } \\
\text { re inden- } \\
\text { for } 1 \text { år } \\
\text { (45-64) }\end{array}$ & $\begin{array}{r}\text { Psykiatri- } \\
\text { ske } \\
\text { patienter, } \\
\text { der er } \\
\text { døde som } \\
\text { følge af } \\
\text { selvmord } \\
\text { pr. } \\
100.000 \\
\text { indbygge- } \\
\text { re inden- } \\
\text { for } 1 \text { år } \\
(65-84)\end{array}$ & $\begin{array}{r}\text { Psykiatri- } \\
\text { ske } \\
\text { patienter, } \\
\text { der er } \\
\text { døde som } \\
\text { følge af } \\
\text { selvmord } \\
\text { pr. } \\
100.000 \\
\text { indbygge- } \\
\text { re inden- } \\
\text { for } 1 \text { år } \\
(85+)\end{array}$ \\
\hline $\begin{array}{l}\text { Danmark } \\
\text { Finland }\end{array}$ & $\begin{array}{l}2,0 \\
4,9\end{array}$ & 5,6 & 2,0 & 5,5 & 7,0 & 5,0 & 9,2 \\
\hline Færøerne & $\mathrm{N} / \mathrm{A}$ & N/A & $\mathrm{N} / \mathrm{A}$ & N/A & N/A & $\mathrm{N} / \mathrm{A}$ & N/A \\
\hline Grønland & 0,0 & N/A & $\mathrm{N} / \mathrm{A}$ & N/A & N/A & $\mathrm{N} / \mathrm{A}$ & N/A \\
\hline Island & N/A & N/A & N/A & N/A & N/A & $\mathrm{N} / \mathrm{A}$ & N/A \\
\hline Norge & $\mathrm{N} / \mathrm{A}$ & N/A & $\mathrm{N} / \mathrm{A}$ & N/A & $\mathrm{N} / \mathrm{A}$ & $\mathrm{N} / \mathrm{A}$ & N/A \\
\hline Sverige & 0,42 & 6,1 & 6,8 & 5,7 & 8,2 & 4,0 & 1,2 \\
\hline
\end{tabular}

Anm.: For selvmord gælder, at selvmordet er sket i 2009, men patienten kan have haft seneste kontakt med psykiatrisk afdeling i 2008. 
Tabel 2.7.6. Selvmord 2009 (Mænd) - basisindikatorer

\begin{tabular}{|c|c|c|c|c|c|c|}
\hline Land & $\begin{array}{r}\text { Psykiatriske } \\
\text { patienter, } \\
\text { der er døde } \\
\text { som følge af } \\
\text { selvmord pr. } \\
100.000 \\
\text { indbyggere } \\
\text { indenfor } 1 \\
\text { år (18+) }\end{array}$ & $\begin{array}{r}\text { Psykiatriske } \\
\text { patienter, } \\
\text { der er døde } \\
\text { som følge af } \\
\text { selvmord pr. } \\
100.000 \\
\text { indbyggere } \\
\text { indenfor } 1 \\
\text { år (18-24) }\end{array}$ & $\begin{array}{r}\text { Psykiatriske } \\
\text { patienter, } \\
\text { der er døde } \\
\text { som følge af } \\
\text { selvmord pr. } \\
100.000 \\
\text { indbyggere } \\
\text { indenfor } 1 \\
\text { år (25-44) }\end{array}$ & $\begin{array}{r}\text { Psykiatriske } \\
\text { patienter, } \\
\text { der er døde } \\
\text { som følge af } \\
\text { selvmord pr. } \\
100.000 \\
\text { indbyggere } \\
\text { indenfor } 1 \\
\text { år (45-64) }\end{array}$ & $\begin{array}{r}\text { Psykiatriske } \\
\text { patienter, } \\
\text { der er døde } \\
\text { som følge af } \\
\text { selvmord pr. } \\
100.000 \\
\text { indbyggere } \\
\text { indenfor } 1 \\
\text { år (65-84) }\end{array}$ & $\begin{array}{r}\text { Psykiatriske } \\
\text { patienter, } \\
\text { der er døde } \\
\text { som følge af } \\
\text { selvmord pr. } \\
100.000 \\
\text { indbyggere } \\
\text { indenfor } 1 \\
\text { år (85+) }\end{array}$ \\
\hline Danmark & 7,9 & 3,4 & 8,3 & 9,3 & 7,2 & 9,1 \\
\hline Finland & N/A & N/A & N/A & N/A & $\mathrm{N} / \mathrm{A}$ & N/A \\
\hline Færøerne & N/A & N/A & N/A & N/A & N/A & N/A \\
\hline Grønland & N/A & N/A & N/A & N/A & N/A & N/A \\
\hline Island & N/A & N/A & N/A & N/A & $\mathrm{N} / \mathrm{A}$ & $\mathrm{N} / \mathrm{A}$ \\
\hline Norge & N/A & N/A & N/A & N/A & $\mathrm{N} / \mathrm{A}$ & N/A \\
\hline Sverige & 6,2 & 7,5 & 7,8 & 9,9 & 4,5 & 3,7 \\
\hline
\end{tabular}

Anm.: For selvmord gælder, at selvmordet er sket i 2009, men patienten kan have haft seneste kontakt med psykiatrisk afdeling i 2008. For Sverige er der i stedet for $18+$ befolkningen anvendt hele befolkningen.

Tabel 2.7.7. Selvmord 2009 (Kvinder) - basisindikatorer

\begin{tabular}{|c|c|c|c|c|c|c|}
\hline Land & $\begin{array}{r}\text { Psykiatriske } \\
\text { patienter, } \\
\text { der er døde } \\
\text { som følge af } \\
\text { selvmord } \\
\text { pr. } 100.000 \\
\text { indbyggere } \\
\text { indenfor } 1 \\
\text { år (18+) }\end{array}$ & $\begin{array}{r}\text { Psykiatriske } \\
\text { patienter, } \\
\text { der er døde } \\
\text { som følge af } \\
\text { selvmord } \\
\text { pr. } 100.000 \\
\text { indbyggere } \\
\text { indenfor } 1 \\
\text { år (18-24) }\end{array}$ & $\begin{array}{r}\text { Psykiatriske } \\
\text { patienter, } \\
\text { der er døde } \\
\text { som følge af } \\
\text { selvmord } \\
\text { pr. 100.000 } \\
\text { indbyggere } \\
\text { indenfor } 1 \\
\text { år (25-44) }\end{array}$ & $\begin{array}{r}\text { Psykiatriske } \\
\text { patienter, } \\
\text { der er døde } \\
\text { som følge af } \\
\text { selvmord } \\
\text { pr. } 100.000 \\
\text { indbyggere } \\
\text { indenfor } 1 \\
\text { år (45-64) }\end{array}$ & $\begin{array}{r}\text { Psykiatriske } \\
\text { patienter, } \\
\text { der er døde } \\
\text { som følge af } \\
\text { selvmord } \\
\text { pr. } 100.000 \\
\text { indbyggere } \\
\text { indenfor } 1 \\
\text { år (65-84) }\end{array}$ & $\begin{array}{r}\text { Psykiatriske } \\
\text { patienter, } \\
\text { der er døde } \\
\text { som følge af } \\
\text { selvmord } \\
\text { pr. } 100.000 \\
\text { indbyggere } \\
\text { indenfor } 1 \\
\text { år (85+) }\end{array}$ \\
\hline Danmark & 3,4 & 0,5 & 2,6 & 4,7 & 3,1 & 9,2 \\
\hline Finland & N/A & N/A & N/A & $\mathrm{N} / \mathrm{A}$ & $\mathrm{N} / \mathrm{A}$ & $\mathrm{N} / \mathrm{A}$ \\
\hline Færøerne & N/A & N/A & N/A & $\mathrm{N} / \mathrm{A}$ & $\mathrm{N} / \mathrm{A}$ & $\mathrm{N} / \mathrm{A}$ \\
\hline Grønland & N/A & N/A & N/A & $\mathrm{N} / \mathrm{A}$ & $\mathrm{N} / \mathrm{A}$ & N/A \\
\hline Island & N/A & N/A & N/A & $\mathrm{N} / \mathrm{A}$ & $\mathrm{N} / \mathrm{A}$ & N/A \\
\hline Norge & N/A & N/A & N/A & $\mathrm{N} / \mathrm{A}$ & $\mathrm{N} / \mathrm{A}$ & N/A \\
\hline Sverige & 3,7 & 6,0 & 3,4 & 6,4 & 3,5 & 0,0 \\
\hline
\end{tabular}

Anm.: For selvmord gælder, at selvmordet er sket i 2009, men patienten kan have haft seneste kontakt med psykiatrisk afdeling i 2008. For Sverige er der i stedet for $18+$ befolkningen anvendt hele befolkningen.

Bemærkninger til tabel 2.7.5, tabel 2.7.6 og tabel 2.7.7:

Der begås flest selvmord under indlæggelse i Finland med 4,9 pr. 100.000 indbyggere, mens der er færrest i Sverige med 0,42 pr. 100.000 indbyggere. Med hensyn til psykiatriske patienter, der er døde som følge af selvmord viser resultaterne, at der er lidt flere selvmord indenfor 1 år i Sverige med 6,1 pr. 100.000 indbyggere mod 5,6 pr. 100.000 indbyggere i Danmark. Ses der på aldersfordelingen, så er antallet pr. 100.000 størst i Danmark for den ældste aldersgruppe, mens tætheden er størst i Sverige i aldersgruppen 45-64 år. Ses der bort fra den yngste og den ældste aldersgruppe, så fordeler selvmordene pr. 100.000 indbyggere sig ikke signifikant forskelligt $\mathrm{i}$ Danmark og Sverige. Danmark har færrest selvmord pr. 100.000 i den yngste aldersgruppe, mens Sverige har færrest i den ældste aldersgruppe. Generelt er der færre selvmord for kvinder indenfor et år efter kontakt til psykiatrisk afdeling end for mænd. 
Tabel 2.7.8. Ressourcer og aktiviteter i psykiatrien i de nordiske lande - basisindikatorer

\begin{tabular}{|c|c|c|c|c|c|c|}
\hline Land & $\begin{array}{r}\text { Omkostninger } \\
\text { for specialisere- } \\
\text { de psykiatriske } \\
\text { afdelinger pr. } \\
100.000 \text { indbyg- } \\
\text { gere }\end{array}$ & $\begin{array}{r}\text { Antallet } \\
\text { af psykia- } \\
\text { triske } \\
\text { senge, pr. } \\
100.000 \\
\text { indbygge- } \\
\text { re }\end{array}$ & $\begin{array}{r}\text { Udskrivninger } \\
\text { (afsluttede } \\
\text { indlagte } \\
\text { forløb) fra } \\
\text { psykiatriske } \\
\text { enheder, pr. } \\
1.000 \text { indbyg- } \\
\text { gere }\end{array}$ & $\begin{array}{r}\text { Sengedage } \\
\text { pr. } 1.000 \\
\text { indbyggere } i \\
\text { psykiatriske } \\
\text { enheder }\end{array}$ & $\begin{array}{r}\text { Gennemsnitlig } \\
\text { liggetid på } \\
\text { psykiatriske } \\
\text { enheder }\end{array}$ & $\begin{array}{r}\text { Antallet af } \\
\text { psykisk syge } \\
\text { patienter der } \\
\text { er indlagt på } \\
\text { sygehus } \\
\text { kontinuerligt i } \\
\text { mere end } 1 \\
\text { år, pr. } 100.000 \\
\text { indbyggere }\end{array}$ \\
\hline Danmark & $\mathrm{N} / \mathrm{A}$ & $\begin{array}{r}57,8 \\
(2009)\end{array}$ & 7,1 (2005) & $206,8(2005)$ & $29(2005)$ & 6 (2004) \\
\hline Finland & N/A & $80(2008)$ & $8,7(2005)$ & $347,9(2005)$ & $40(2005)$ & 30 (2004) \\
\hline Færøerne & 104.000.000 DKK ${ }^{1}$ & N/A & $9,7^{2}$ & $226,8^{2}$ & $23^{2}$ & N/A \\
\hline Grønland & N/A & $\mathrm{N} / \mathrm{A}$ & N/A & N/A & $\mathrm{N} / \mathrm{A}$ & N/A \\
\hline Island & $\mathrm{N} / \mathrm{A}$ & N/A & $8,7^{3}$ & $119,9^{3}$ & $13^{3}$ & $2(2005)$ \\
\hline Norge & $\mathrm{N} / \mathrm{A}$ & $90(2008)$ & $7,8(2005)$ & $202,1(2005)$ & $26(2005)$ & $\mathrm{N} / \mathrm{A}$ \\
\hline Sverige & $\mathrm{N} / \mathrm{A}$ & $\mathrm{N} / \mathrm{A}$ & $8,4(2005)$ & $157,5(2005)$ & $19(2005)$ & $13(2002)$ \\
\hline
\end{tabular}

Anm.: ${ }^{1}$ Tallet er baseret på et gennemsnit for 2005-2009. ${ }^{2}$ Tallene er baseret på et gennemsnit for 2001-2005. ${ }^{3}$ Tallene er baseret på et gennemsnit for 2003-2005. Tal for Sengedage, gennemsnitlig liggetid samt antallet af psykisk syge patienter der er indlagt på sygehus kontinuerligt i mere end 1 år er for alle lande fra Nomesco.

Bemærkninger: Resultater fra Færøerne og Island er ikke sammenlignelige med de øvrige landes resultater pga. det begrænsede datagrundlag jf. indledende kommentarer. Norge har flest psykiatriske senge pr. 100.000 indbyg gere, mens Danmark har færrest pr. 100.000 indbyggere. Vedrørende udskrivninger fra psykiatriske enheder, så er resultaterne ikke signifikant forskellige. Finland har flest med 8,7 pr. 100.000 indbyggere, mens Danmark har færrest med 7,1 pr. 100.000 indbyggere. Finland har signifikant flere sengedage pr. 1.000 indbyggere i psykiatriske enheder med 347,9, mens Sverige har færrest med 157,5. Den gennemsnitlige liggetid på psykiatriske enheder er st $\varnothing$ rst i Finland med 40 dage, mens den er lavest i Sverige med 19 dage.

Ved psykisk syge patienter, der er indlagt kontinuerligt i mere end 1 år, har Finland signifikant flere patienter end $\emptyset$ vrige lande med 30 pr. 100.000 indbyggere, mens Danmark har færrest med 6 pr. 100.000 indbyggere. Tallene for Færøerne er baseret på indlagte patienter.

Tabel 2.7.9. Hospitalsbehandling på psykiatriske enheder 2005 (Samlet) - basisindikatorer

\begin{tabular}{|c|c|c|c|c|c|c|c|}
\hline Land & $\begin{array}{r}\text { Psykiatri- } \\
\text { ske } \\
\text { patienter } \\
\text { pr. } 1.000 \\
\text { indbyg- } \\
\text { gere } \\
\text { (Samlet) }\end{array}$ & $\begin{array}{r}\text { Psykiatri- } \\
\text { ske } \\
\text { patienter } \\
\text { pr. } 1.000 \\
\text { indbygge- } \\
\text { re (0-14) }\end{array}$ & $\begin{array}{r}\text { Psykiatri- } \\
\text { ske } \\
\text { patienter } \\
\text { pr. } 1.000 \\
\text { indbygge- } \\
\text { re (15-29) }\end{array}$ & $\begin{array}{r}\text { Psykiatri- } \\
\text { ske } \\
\text { patienter } \\
\text { pr. } 1.000 \\
\text { indbygge- } \\
\text { re }(30-44)\end{array}$ & $\begin{array}{r}\text { Psykiatri- } \\
\text { ske } \\
\text { patienter } \\
\text { pr. } 1.000 \\
\text { indbygge- } \\
\text { re (45-64) }\end{array}$ & $\begin{array}{r}\text { Psykiatri- } \\
\text { ske } \\
\text { patienter } \\
\text { pr. } 1.000 \\
\text { indbygge- } \\
\text { re (65-79) }\end{array}$ & $\begin{array}{r}\text { Psykiatri } \\
\text { ske } \\
\text { patiente } \\
\text { pr. } 1.000 \\
\text { indbygge } \\
\text { re }(80+\end{array}$ \\
\hline Danmark & 4,6 & 0,4 & 5,3 & 6,3 & 5,6 & 4,4 & 5,2 \\
\hline Finland & 5,6 & 1,7 & 6,7 & 7,1 & 6,7 & 4,6 & 4,5 \\
\hline Færøerne & 6,9 & 2,4 & 7 & 6 & 10,6 & 8,6 & 12,2 \\
\hline Grønland & 2,44 & 1,77 & 4,48 & 3,47 & 2,71 & 0,6 & 0,0 \\
\hline Island & 6,3 & 0,9 & 6,8 & 6,9 & 7,0 & 9,8 & $22, \mathrm{C}$ \\
\hline Norge & 5,8 & 1,0 & 7,5 & 7,4 & 5,9 & 5,9 & 10,5 \\
\hline Sverige & 5,4 & 0,3 & 6,3 & 6,3 & 7,3 & 4,5 & 3,8 \\
\hline
\end{tabular}

Anm.: Tal for Færøerne er beregnet som gennemsnit for 2001-2005. Tal for Island er beregnet som gennemsnit for 2003-2005. Data for Norge er ikke fuldstændig. Tal for Grønland er for 2010. Resultater med undtagelse af dem fra Grønland stammer fra Nomesco.

Bemærkning: Tallene for Færøerne er baseret på indlagte patienter. 
Tabel 2.7.10. Hospitalsbehandling på psykiatriske enheder 2005 (Mænd) - basisindikatorer

\begin{tabular}{|c|c|c|c|c|c|c|c|}
\hline Land & $\begin{array}{r}\text { Psykia- } \\
\text { triske } \\
\text { patienter } \\
\text { pr. } 1.000 \\
\text { indbyg- } \\
\text { gere } \\
\text { (Samlet) }\end{array}$ & $\begin{array}{r}\text { Psykiatri- } \\
\text { ske } \\
\text { patienter } \\
\text { pr. } 1.000 \\
\text { indbygge- } \\
\text { re (0-14) }\end{array}$ & $\begin{array}{r}\text { Psykiatri- } \\
\text { ske } \\
\text { patienter } \\
\text { pr. } 1.000 \\
\text { indbygge- } \\
\text { re (15-29) }\end{array}$ & $\begin{array}{r}\text { Psykiatri- } \\
\text { ske } \\
\text { patienter } \\
\text { pr. } 1.000 \\
\text { indbygge- } \\
\text { re }(30-44)\end{array}$ & $\begin{array}{r}\text { Psykiatri- } \\
\text { ske } \\
\text { patienter } \\
\text { pr. } 1.000 \\
\text { indbygge- } \\
\text { re (45-64) }\end{array}$ & $\begin{array}{r}\text { Psykiatri- } \\
\text { ske } \\
\text { patienter } \\
\text { pr. } 1.000 \\
\text { indbygge- } \\
\text { re (65-79) }\end{array}$ & $\begin{array}{r}\text { Psykiatri- } \\
\text { ske } \\
\text { patienter } \\
\text { pr. } 1.000 \\
\text { indbygge- } \\
\text { re }(80+)\end{array}$ \\
\hline Danmark & 4,4 & 0,3 & 4,8 & 6,8 & 5,5 & 3,5 & 4,8 \\
\hline Finland & 5,7 & 2,2 & 6,2 & 7,8 & 6,8 & 4,0 & 4,3 \\
\hline Færøerne & 8,1 & 2,8 & 6,7 & 8,0 & 11,9 & 11,0 & 17,8 \\
\hline Grønland & 2,4 & 0,0 & 5,5 & 4,0 & 2,0 & 0,0 & 0,0 \\
\hline Island & 6,0 & 1,1 & 6,6 & 7,1 & 6,7 & 8,4 & 22,9 \\
\hline Norge & 5,6 & 1,2 & 6,6 & 7,3 & 6,1 & 5,6 & 10,9 \\
\hline Sverige & 5,6 & 0,2 & 5,6 & 7,7 & 8,2 & 4,5 & 3,8 \\
\hline
\end{tabular}

Anm.: Tal for Færøerne er beregnet som gennemsnit for 2001-2005. Tal for Island er beregnet som gennemsnit for 2003-2005. Data for Norge er ikke fuldstændig. Tal for Grønland er for 2010. Resultater med undtagelse af dem fra Grønland stammer fra Nomesco.

Bemærkning: Tallene for Færøerne er baseret på indlagte patienter.

Tabel 2.7.11. Hospitalsbehandling på psykiatriske enheder 2005 (Kvinder) - basisindikatorer

\begin{tabular}{|c|c|c|c|c|c|c|c|}
\hline Land & $\begin{array}{r}\text { Psykia- } \\
\text { triske } \\
\text { patien- } \\
\text { ter pr. } \\
1.000 \\
\text { indbyg- } \\
\text { gere } \\
\text { (Samlet) }\end{array}$ & $\begin{array}{r}\text { Psykiatri- } \\
\text { ske } \\
\text { patienter } \\
\text { pr. } 1.000 \\
\text { indbygge- } \\
\text { re (0-14) }\end{array}$ & $\begin{array}{r}\text { Psykiatri- } \\
\text { ske } \\
\text { patienter } \\
\text { pr. } 1.000 \\
\text { indbygge- } \\
\text { re (15-29) }\end{array}$ & $\begin{array}{r}\text { Psykiatri- } \\
\text { ske } \\
\text { patienter } \\
\text { pr. } 1.000 \\
\text { indbygge- } \\
\text { re (30-44) }\end{array}$ & $\begin{array}{r}\text { Psykiatri- } \\
\text { ske } \\
\text { patienter } \\
\text { pr. } 1.000 \\
\text { indbygge- } \\
\text { re (45-64) }\end{array}$ & $\begin{array}{r}\text { Psykiatri- } \\
\text { ske } \\
\text { patienter } \\
\text { pr. } 1.000 \\
\text { indbygge- } \\
\text { re (65-79) }\end{array}$ & $\begin{array}{r}\text { Psykiatri- } \\
\text { ske } \\
\text { patienter } \\
\text { pr. } 1.000 \\
\text { indbygge- } \\
\text { re }(80+)\end{array}$ \\
\hline Danmark & 4,7 & 0,5 & 5,9 & 5,8 & 5,6 & 5,1 & 5,4 \\
\hline Finland & 5,5 & 1,3 & 7,2 & 6,3 & 6,6 & 5,1 & 4,6 \\
\hline Færøerne & 5,7 & 2,0 & 7,3 & 3,6 & 9,1 & 6,3 & 8,8 \\
\hline Grønland & 2,5 & 0,5 & 3,4 & 2,9 & 3,6 & 1,2 & 0,0 \\
\hline Island & 6,5 & 0,7 & 7,1 & 6,7 & 7,4 & 11,1 & 21,5 \\
\hline Norge & 6,0 & 0,9 & 8,5 & 7,5 & 5,7 & 6,1 & 10,9 \\
\hline Sverige & 5,1 & 0,5 & 7,1 & 6,6 & 6,4 & 4,5 & 3,8 \\
\hline
\end{tabular}

Anm.: Tal for Færøerne er beregnet som gennemsnit for 2001-2005. Tal for Island er beregnet som gennemsnit for 2003-2005. Data for Norge er ikke fuldstændig. Tal for Grønland er for 2010. Resultater med undtagelse af dem fra Grønland stammer fra Nomesco.

Bemærkninger til tabel 2.7.9, tabel 2.7.10 og tabel 2.7.11:

Data fra Færøerne, Grønland og Island er ikke sammenlignelige med de øvrige landes, da datagrundlaget er småt jf. de indledende kommentarer. Resultaterne for psykiatriske patienter viser, at de ikke er signifikant forskellige. Danmark har færrest med 4,6 pr. 1.000 indbyggere, mens Norge har flest med 5,8 pr. 1.000 indbyggere. De psykiatriske patienter fordeler sig jævnt på alle aldersgrupperne med undtagelse af den yngste, som har markant færre pr. 1.000 indbyggere i alle landene. Endvidere har Norge mange i den ældste aldersgruppe. Danmark og Norge har flere kvindelige psykiatriske patienter end mandlige pr. 1.000 indbyggere, mens Finland og Sverige har flere mænd med psykiatrisk sygdom pr. 1.000 indbyggere end kvinder. Tallene for Færøerne er baseret på indlagte patienter. 
Tabel 2.7.12. Behandlede patienter fordelt på diagnosegrupper 2005 (Mænd) - basisindikatorer

\begin{tabular}{|c|c|c|c|c|}
\hline Land & $\begin{array}{r}\text { Behandlede patien- } \\
\text { ter pr. } 1.000 \text { indbyg- } \\
\text { gere på psykiatriske } \\
\text { enheder (ICD-10: } \\
\text { F10-19) }\end{array}$ & $\begin{array}{r}\text { Behandlede patien- } \\
\text { ter pr. } 1.000 \text { indbyg- } \\
\text { gere på psykiatriske } \\
\text { enheder (ICD-10: } \\
\text { F20-25) }\end{array}$ & $\begin{array}{r}\text { Behandlede patien- } \\
\text { ter pr. } 1.000 \text { indbyg- } \\
\text { gere på psykiatriske } \\
\text { enheder (ICD-10: } \\
\text { F28-29) }\end{array}$ & $\begin{array}{r}\text { Behandlede patien- } \\
\text { ter pr. } 1.000 \text { indbyg- } \\
\text { gere på psykiatriske } \\
\text { enheder (ICD-10: } \\
\text { F30-39) }\end{array}$ \\
\hline Danmark & 1,4 & 0,4 & 0,1 & 1,0 \\
\hline Finland & 2,1 & 0,6 & 0,4 & 0,3 \\
\hline Færøerne & 1,6 & 0,4 & 0,0 & 0,4 \\
\hline Grønland & N/A & N/A & $\mathrm{N} / \mathrm{A}$ & N/A \\
\hline Island & 0,9 & 0,2 & 0,0 & 0,4 \\
\hline Norge & 0,9 & 0,3 & 0,1 & 0,6 \\
\hline Sverige & 0,9 & 0,3 & 0,2 & 0,6 \\
\hline
\end{tabular}

Anm.: For Færøerne er tallene baseret på et gennemsnit for 2001-2005. Data for Norge er ikke fuldstændig. Resultater stammer fra Nomesco.

Bemærkning: Tallene for Færøerne er baseret på indlagte patienter.

Tabel 2.7.13. Behandlede patienter fordelt på diagnosegrupper 2005 (Kvinder) - basisindikatorer

\begin{tabular}{|c|c|c|c|c|}
\hline Land & $\begin{array}{r}\text { Behandlede patien- } \\
\text { ter pr. } 1.000 \text { indbyg- } \\
\text { gere på psykiatriske } \\
\text { enheder (ICD-10: } \\
\text { F10-19) }\end{array}$ & $\begin{array}{r}\text { Behandlede patien- } \\
\text { ter pr. } 1.000 \text { indbyg- } \\
\text { gere på psykiatriske } \\
\text { enheder (ICD-10: } \\
\text { F20-25) }\end{array}$ & $\begin{array}{r}\text { Behandlede patien- } \\
\text { ter pr. } 1.000 \text { indbyg- } \\
\text { gere på psykiatriske } \\
\text { enheder (ICD-10: } \\
\text { F28-29) }\end{array}$ & $\begin{array}{r}\text { Behandlede } \\
\text { patienter pr. 1.000 } \\
\text { indbyggere på } \\
\text { psykiatriske } \\
\text { enheder (ICD-10: } \\
\text { F30-39) }\end{array}$ \\
\hline Danmark & 0,9 & 0,5 & 0,0 & 1,7 \\
\hline Finland & 2,0 & 0,8 & 0,3 & 0,5 \\
\hline Færøerne & 1,2 & 0,5 & 0,0 & 0,5 \\
\hline Grønland & N/A & N/A & N/A & N/A \\
\hline Island & 0,6 & 0,2 & 0,1 & 0,9 \\
\hline Norge & 0,7 & 0,4 & 0,0 & 1,1 \\
\hline Sverige & 0,9 & 0,5 & 0,2 & 0,9 \\
\hline
\end{tabular}

Anm.: For Færøerne er tallene baseret på et gennemsnit for 2001-2005. Data for Norge er ikke fuldstændig. Resultater stammer fra Nomesco.

Bemærkninger til tabel 2.5.12 og tabel 2.5.13:

Data for Færøerne og Island er ikke sammenlignelige med de øvrige landes pga. det begrænsede datagrundlag jf.

de indledende kommentarer. Resultaterne for behandlede patienter fordelt på diagnosegrupper viser, at Finland har den højeste rate for stof- og alkoholmisbrug (F10-19) med 2,1 pr. 1.000 mænd og 2,0 pr. 1.000 kvinder. Norge og Sverige har den laveste rate for mænd 0,9 pr. 1.000, mens Norge alene har den laveste rate for kvinder med 0,7 pr. 1.000 .

Finland har den højeste rate for skizofreni (F20-25) med 0,6 pr. 1.000 mænd og 0,8 pr. 1.000 kvinder, og Norge og Sverige har den laveste rate for mænd med 0,3 pr. 1.000, mens Norge har den laveste for kvinder med 0,4 pr. 1.000 .

For andre psykoser (F28-29) har Finland den højeste rate for mænd med 0,4 pr. 1.000 mænd, mens Danmark og Norge deler den laveste rate for med 0,1 pr. 1.000 mænd og 0,0 pr. 1.000 kvinder. Endelig har Danmark den højeste rate for affektive sindslidelser (F30-39) med 1,0 pr. 1.000 mænd og 1,7 pr. 1.000 kvinder, mens Finland har den laveste rate med 0,3 pr. 1.000 mænd og 0,5 pr. 1.000 kvinder. Tallene for Færøerne er baseret på indlagte patienter. 
Anm.: ${ }^{1}$ Dödlighet bland personer vårdade inom sluten psykiatrisk vård någon gång de senaste 5 åren och som avlidit 2006-2009. 20-79 år ${ }^{2}$. Dödlighet i diagnoser som $t$ ex lungcancer, levercirros, motorfordonsolyckor och cancer i matstrupe. Minst ett psykiatriskt vårdtillfälle under 2002-2006 och avliden 2005-2007.25-79 år ${ }^{3}$. Dödlighet i diagnoser som t ex diabetes, blindtarmsinflammation, stroke, gallstenssjukdom. Minst ett psykiatriskt vårdtillfälle under 2002-2006 och avliden 2005-2007.25-79 år ${ }^{4}$. Antal personer med undvikbara slutenvårdstillfällen/100 000 inv 2008. 20-59 år. Personer vårdade inom psykiatri någon gång under 2003-2007.

Bemærkninger: I Socialstyrelsens rapport öppna jämförelser och utvärdering 2010 - psykiatrisk vård användes ovanstående indikatorer för att påvisa ökad risk för död och somatisk sjukdom för patienter med tidigare psykiatrisk vårdkontakt. För för mer information om indikatorerna och resultatet hänvisas till rapporten. 


\begin{tabular}{lcc} 
& Norge & Sverige \\
\hline Andel patienter som er diagnostisk vurderet i forhold til klinisk psykiatrisk syndrom & $73,7 \%$ \\
Andel patienter som er diagnostisk vurderet i forhold til specifikke udviklingsforstyrrelser & $39,5 \%$ \\
Andel patienter som er diagnostisk vurderet i forhold til aktuelle vanskelige psykosociale & $60,7 \%$ \\
forhold & $58,1 \%$ \\
Andel patienter som er diagnostisk vurderet i forhold til global vurdering af psykosocialt & \\
funktionsniveau (CGAS) & $26,5 \%$ \\
Andel patienter der har ventet mere end 90 dage på besøg i børne- og ungdomspsikiatri & $57,1 \%$ \\
Andel patienter med ventetid under 60 dage (ventetid fra henvisning til start på under- & \\
søgelse) & $26,0 \%$ & $66,0 \%{ }^{1}$ \\
Andel patienter der har ventet i højest 30 dage på aftale på en børne- og ungdomspsyki- \\
atri klinik
\end{tabular}

Anm.: ${ }^{1}$ Andel som har väntat högst 30 dagar på besök inom barn- och ungdomspsykiatri 31 mars 2010.

Bemærkninger: Andel pasienter i psykisk helsevern for barn og unge som er diagnostisk vurdert i forhold til henholdsvis Akse 1, 2, 5 og 6 i Multiaksial klassifikasjon av barne- og ungdomspsykiatriske forstyrrelser er en kvalitetsindikator som det rapporteres på i Norge. Dette er et klassifikasjonssystem som dels er basert på ICD-10 og dels på etablert praksis i det pasientadministrative datasystemet som brukes av fagfeltet. Multiaksial klassifikasjon og diagnostiske akser:

Akse 1 Klinisk psykiatrisk syndrom

Akse 2 Spesifikke utviklingsforstyrrelser

Akse 5 Aktuelle vanskelige psykososiale forhold

Akse 6 Global vurdering av psykososialt funksjonsnivå (CGAS)

Pasienten forutsettes å være diagnostisk vurdert når diagnoser er registrert i journalsystemet. Det forventes

generelt at alle saker blir diagnostisk vurdert, og at denne diagnostiske vurderingen blir registrert så snart dette er forsvarlig i starten av kontakten.

Tjenestene i Norge er pålagt å gi barn og unge behandling innen en viss frist og må rapportere ventetid.

Barn/ungdom under 23 år som henvises spesialisthelsetjenesten med psykiske lidelser og/eller rusproblemer har rett til å få henvisningen vurdert innen 10 dager og nødvendig helsehjelp oppstartet innen 65 dager.

\subsubsection{Eksempel fra Sverige på overdødelighed for patienter med psykiatrisk sygdom}

I rapporten Öppna jämförelser och utvärdering 2010. Psykiatrisk vård kunde Socialstyrelsen visa indikatorer som pekade på en överdödlighet $\mathrm{i}$ hjärtinfarkt och stroke bland patienter med en erfarenhet av psykiatrisk vård.

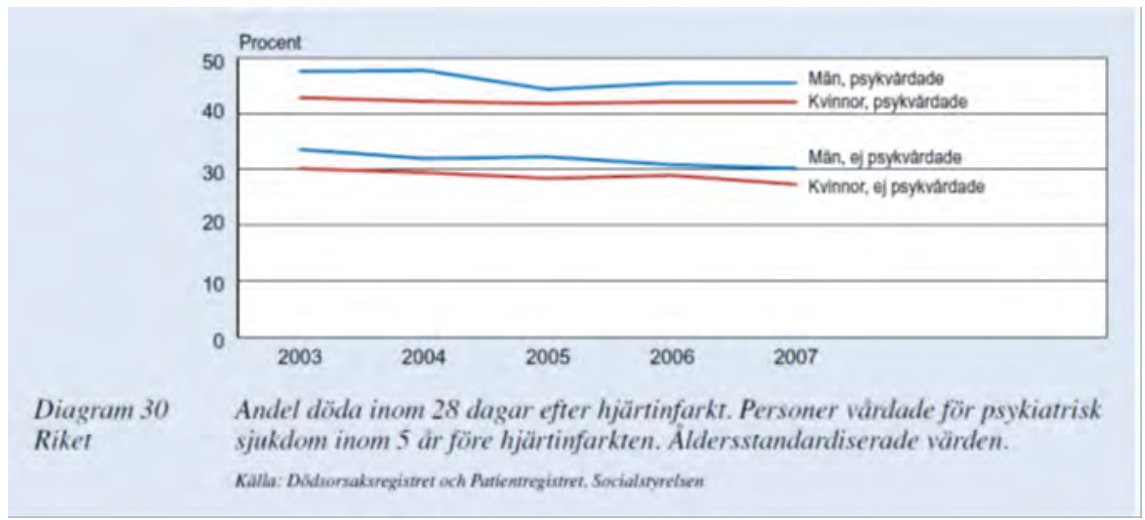

Figur 2.3: Andel döda inom 28 dagar efter hjärtinfarkt 


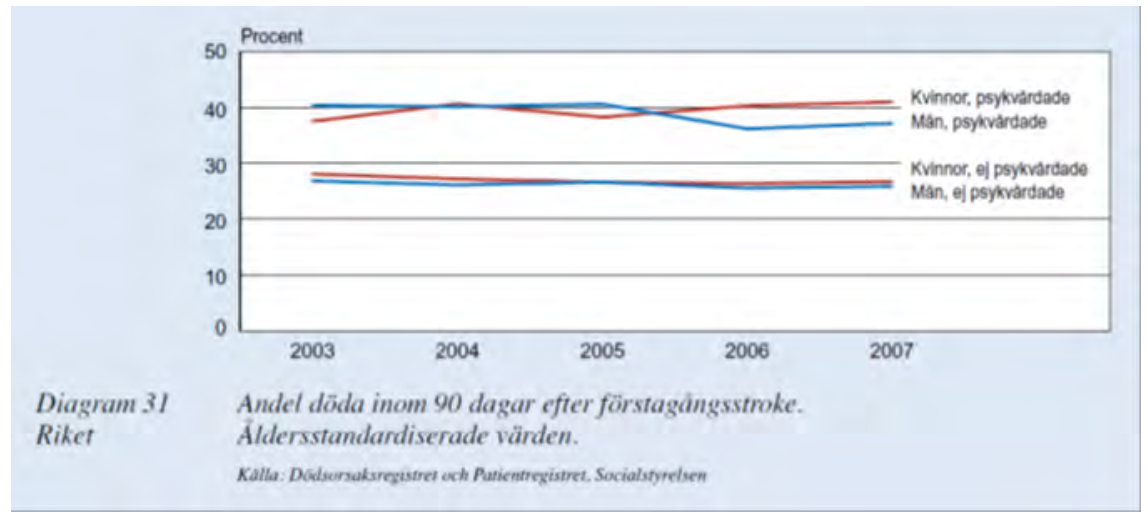

Figur 2.4: Andel döda inom 90 dagar efter förstagångsstroke

För att ytterligare fördjupa kunskaperna om psykiskt sjukas situation vid somatisk sjukdom har studier genomförts av förtida död och perifer neuropati vid diabetes samt karotiskirurgi vis stroke eller TIA om tecken på åderförkalkning i halspulsådern föreligger satt i relation till psykisk sjukdom eller inte. Även ytterligare studier om förtida död vid stroke och samtidig psykisk sjukdom har gjort. Rapporterna visar att psykiskt sjuka patienter har sämre förutsättningar än övriga patienter när det gäller hälsoutfall, tillgång till vårdåtgärder och läkemedel. För mer information hänvisas till webbsidorna:

- http://www.socialstyrelsen.se/Lists/Artikelkatalog/Attachments/18 320/2011-5-3.pdf

- http://www.socialstyrelsen.se/publikationer2011/2011-2-5

- http://www.socialstyrelsen.se/publikationer2010/2010-6-6

\subsection{Tvangsforanstaltninger i de nordiske lande}

I de nordiske lande er det lovmæssige grundlag for tvangsforanstaltninger forskelligt. Nedenfor beskrives, hvorledes tvangsforanstaltninger håndteres i de respektive nordiske lande.

\subsubsection{Danmark}

Sundhedsstyrelsens opgørelse over anvendelse af tvangsforanstaltninger over for patienter indlagt på psykiatriske sygehusafdelinger viser, at anvendelsen af tvang er forholdsvis stabil, idet der altid må forventes tilfældige mindre udsving fra år til år.

Omkring hver 5. patient indlagt på en psykiatrisk afdeling bliver omfattet af én eller flere tvangsforanstaltninger.

Anvendelse af tvang kan kun finde sted, hvis betingelserne, der er beskrevet i Lov om anvendelse af tvang i psykiatrien, er opfyldt (1). Tvang kan være nødvendigt for at beskytte patienter med en psykisk lidelse, som er til fare for sig selv eller andre. 
Der arbejdes fortsat på at reducere anvendelse af tvang i psykiatrien samt sikre god kvalitet, når tvang anvendes bl.a. i relation til en række satspuljeprojekter mv.

Tabel 2.8.1. Anvendelse af tvangsforanstaltninger på psykiatriske afdelinger i 2009 i Danmark

\begin{tabular}{lrrrr}
\hline $\begin{array}{l}\text { Tvangsforanstalt- } \\
\text { ning }\end{array}$ & $\begin{array}{r}\text { Antal indlagte } \\
\text { personer på psykia- } \\
\text { triske afdelinger }\end{array}$ & $\begin{array}{r}\text { Antal personer } \\
\text { omfattet af tvang }\end{array}$ & $\begin{array}{r}\text { Antal tvangs- } \\
\text { foranstaltninger }\end{array}$ & $\begin{array}{r}\text { Andel psykiatriske } \\
\text { patienter omfattet } \\
\text { af tvang }\end{array}$ \\
\hline $\begin{array}{l}\text { Frihedsberøvelser } \\
\text { Tvangsbehandlinger }\end{array}$ & $\cdot$ & 4350 & 5853 \\
Fiksering og/eller \\
fysisk magt
\end{tabular}$\quad \cdot \begin{array}{r}* * \\
\text { Beskyttelsesforan- }\end{array}$

Kilde: Anvendelse af tvang i psykiatrien 2009, april 2011, Sundhedsstyrelsen http://www.sst.dk/publ/Publ2011/DAF/Sundhedsdata/TvangIPsykiatrien.pdf

Note: Opgjort pr. 24. marts 2011.** Antal påbegyndte tvangsbehandlingsforløb i 2009 var 1087. Sundhedsstyrelsen følger antal påbegyndte forløb og ikke antallet af enkelte indgivelser under tvang.

Der henvises i øvrigt til følgende rapporter:

Pludselig uventet $\mathrm{d} \varnothing \mathrm{d}$ hos patienter med psykiatrisk sygdom 2009

http://www.sst.dk/publ/Publ2009/EFT/Psykiatrien/Pludselig_uventet_doed.pdf

Tvangsforanstaltninger i psykiatrien, en udredning 2009

2009:http://www.sst.dk/publ/Publ2009/EFT/Psykiatrien/Tvang_i_psyk.pdf

\subsubsection{Finland}

Enligt 8-14 § i mentalvårdslag (14.12.1990/1116, uppdaterad senast (11.12.2009/1066) kan vård oberoende av patientens vilja beslutas endast om 1) patienten konstateras vara mentalsjuk, 2) patientens vårdbehov på grund av mentalsjukdomen är sådant att hans sjukdom väsentligt skulle förvärras eller det allvarligt skulle äventyra hans eller andras hälsa eller säkerhet om han inte får vård och 3)andra mentalvårdstjänster inte är lämpliga eller de är otillräckliga.

För utredning av om det finns förutsättningar för beslut om vård oberoende av patientens vilja kan denne tas in på sjukhus för observation.

För remiss till observation skall en läkare undersöka patienten och, om han anser det nödvändigt att beslut om vård fattas, skriva ett läkarutlåtande (observationsremiss). Observationsremissen skall innehålla ett motiverat ställningstagande till om det sannolikt finns förutsättningar för beslut om vård. Patienten kan tas in för observation på basis av en observationsremiss som skall bygga på en undersökning av patienten 
högst tre dagar tidigare. Ett villkor för intagning för observation är att det sannolikt finns förutsättningar för beslut om vård.

Senast den fjärde dagen efter intagningen för observation skall den för observationen ansvarige läkaren ge ett skriftligt observationsutlåtande om den som har tagits in. Observationsutlåtandet skall innehålla ett motiverat ställningstagande till om det finns förutsättningar för beslut om vård oberoende av patientens vilja.

Om det under observationstiden framgår att det inte finns förutsättningar för att bestämma att den som intagits för observation skall tas in för vård, skall observationen genast avbrytas och den intagne skrivas ut från sjukhuset, ifall han så önskar.

Innan beslut om vård fattas skall det klarläggas vad den som har tagits in för observation själv anser. Beslut om att den som har varit intagen för observation skall tas in för vård oberoende av sin vilja fattas av den överläkare som ansvarar för den psykiatriska vården vid sjukhuset eller, om denne är jävig eller har förhinder, av någon annan specialist $\mathrm{i}$ första hand i psykiatri som har förordnats att sköta uppgiften.

Beslutet, som skall vara skriftligt och bygga på observationsremissen, observationsutlåtandet och sjukjournalen, skall fattas senast den fjärde dagen efter intagningen för observation. Beslutet skall innehålla ett motiverat ställningstagande till om det finns förutsättningar för vård oberoende av patientens vilja. Det skall utan dröjsmål delges patienten.

Den som vårdbeslutet gäller kan hållas kvar oberoende av sin vilja $i$ högst tre månader. Om det före utgången av denna tid förefaller uppenbart att det är nödvändigt med fortsatt vård även därefter, men samförstånd om detta inte uppnås med patienten, måste ett nytt observationsutlåtande ges för klarläggande av om det fortfarande finns förutsättningar för beslut om vård oberoende av patientens vilja.

Med stöd av ett beslut om fortsatt vård får patienten oberoende av sin vilja hållas intagen för vård i högst sex månader. Därefter skall undersökas om det finns förutsättningar för beslut om vård oberoende av patientens vilja.

Om den som av egen vilja har tagits in för vård på ett sjukhus vill bli utskriven, men den läkare som skall besluta om avslutandet av vården anser att det finns förutsättningar för att bestämma att patienten skall vårdas oberoende av sin vilja, kan denne ställas under observation.

Beslut om vård oberoende av patientens vilja skall på basis av observationsutlåtandet fattas av läkaren senast den fjärde dagen efter att patienten meddelat att han vill bli utskriven.

Om det vid vården av den som ett vårdbeslut gäller visar sig att det inte finns förutsättningar för vård oberoende av patientens vilja, skall vården genast avslutas och patienten skrivas ut från sjukhuset, om han så önskar.

Social- och hälsoministeriet har utsatt en arbetsgrupp för klientens självbestämmanderätt inom social- och hälsovården. Dess uppdrag är att i mån av möjlighet samla i en enda författning alla bestämmelser som 
begränsar klientens och patientens självbestämmenderätt inom socialoch hälsovården. Behovet att revidera lagstiftningen gäller speciellt tvångs- och skyddsåtgärder som används i tjänster för personer med utvecklings-störning eller demens, säkerställande av vård och behandling för gravida kvinnor med missbruksproblem samt åtgärder inom den somatiska och psykiatriska vårdens som används för att begränsa självbestämmende-rätten. Gruppens frist för att rapportera sina rekommendationer är 31. december 2011.

\section{Statistik}

THL samlar in information om tvångsåtgärder. Med blanketten för tilläggsuppgifter om patient inom psykiatrisk specialitet fås uppgifter om tvångsåtgärder (vårddygn oberoende av vilja, isolering, bälte, medicininjektion mot viljan, fysiskt fasthållande).

Vårdperioder som inletts 2009 omfattade drygt 28300 patienter. Av dessa fick man uppgifter åtminstone för en tilläggsblankett om ca 28100 patienter. Antalet rapporterade patienter som varit föremål för tvångsåtgärder var $3050(10,2 \%)$ av alla patienter. Av patienterna hade 1860 isolerats (6,6 \%), $908(3,2 \%)$ hade haft bälte, medicininjektion mot viljan hade getts till $578(2,1 \%)$ och $413(1,5 \%)$ hade upplevt fysiskt fasthållande. Både antalen och andelen var en aning mindre än året innan.

Källa: Psykiatrian erikoisalan laitoshoito 2009 - Institutionsvård inom specialiteten psykiatri 2009. Statistikrapport 4/2011.Finlands officiella statistik, Hälsa 2011. THL (2).

http://www.stakes.fi/FI/tilastot/aiheittain/Mielenterveys/index.htm

\subsubsection{Færøerne}

Hvis betingelserne beskrevet i den færøske lov om tvang i psykiatrien (3) er opfyldt, kan anvendelse af tvang finde sted med det formål at beskytte patienter med psykisk lidelse, som er til fare for sig selv eller andre.

Der kan blive tale om tvangsindlæggelse, tvangstilbageholdelse, tvangsbehandling, fiksering med bælte, hånd- og fodremme, anvendelse af fysisk magt, personlige alarm- og pejlesystemer og, særlige dørlås.

\subsubsection{Grønland}

Tvangsforanstaltninger er i Grønland fortsat reguleret efter den danske „Lov om sindsyge personers hospitalsophold“ fra 1938 med efterfølgende ændringer og igennem „Cirkulære nr. 10 fra 1996 om frihedsberøvelse ved indlæggelse, ophold og behandling på Dronning Ingrids Hospitals psykiatriske afdeling" $(4,5)$.

Behovet for at tvangsindlægge en patient kan opstå ved nyopstået psykisk sygdom, eller hvis en erkendt psykisk syg ophører med sin medicinske behandling og igen bliver sindssyg. Tvangsindlæggelser overvåges af Landslægeembedet. Der ser ud til at være en stigning i antallet af tvangsindlagte og af patienter med behov for indlæggelse på den 
skærmede enhed på den landsdækkende psykiatriske afdeling A1 på Dronning Ingrids Hospital i Nuuk.

\begin{tabular}{|c|c|c|c|c|c|}
\hline & 2004 & 2005 & 2006 & 2007 & 2008 \\
\hline På „gule papirer“ & 1 & 8 & 6 & 4 & 11 \\
\hline På „røde papirer“ & 14 & 17 & 9 & 20 & 29 \\
\hline I alt & 15 & 25 & 15 & 24 & 40 \\
\hline
\end{tabular}

Kilde: Data: administrationen, Dronning Ingrids Hospital

Ud over, at en patient kan blive tvangsindlagt er der også i hht. cirkulæret mulighed for at tvangstilbageholde eller tvangsbehandle en patient, hvis patienten er sindssyg eller i en sindssyg lignende tilstand, der gør det uforsvarligt ikke at frihedsberøve eller tvangsbehandle den pågældende. I 2009 blev 36 patienter tvangstilbageholdt i psykiatrisk afdeling A1, mens 2 patienter blev tvangsbehandlet.

Tvangsfiksering må kun ske, når patienten udsætter sig selv eller andre for nærliggende fare, truer med dette, forfølger eller groft forulemper medpatienter eller udøver betydeligt hærværk. Ved tvangsfiksering kan benyttes bælte, håndremme, fodremme og handsker. I 2009 blev 45 patienter tvangsfikseret.

\subsubsection{Island}

Lov om umyndiggörelse (no. 71/1997) handler om at hvis en person anses til ikke at have styr på sit liv på sit liv blandt andet på grund av psykisk sygdom, misbrug av alcohol eller stoffer, så kan hun umyndiggöres af offentlige myndigheder (dommer).

\subsubsection{Norge}

Tvangsinnleggelser i Norge. Bruk av tvang i psykisk helsevern for voksne i 2009.

De innrapporterte data til Norsk pasientregister (NPR) fra det psykiske helsevernet i Norge om bruk av tvang, har fortsatt ikke en tilfredsstillende kompletthet og kvalitet. Helsemyndighetene har satt et betydelig fokus på dette og det er stilt tydelige krav til de regionale helseforetakene om at de skal sørge for riktig og konsekvent registrering. Dette vil bli fulgt opp fremover, blant annet gjennom den nye nasjonale strategien for redusert og riktig bruk av tvang i de psykiske helsetjenestene.

I Norge skal institusjonene rapportere til Norsk pasientregister (NPR) både om selve tvangsinnleggelsene (tvungen observasjon og tvungen psykisk helsevern), og om vedtak etter kapittel 4 i lov om psykisk helsevern. Slike vedtak etter kapittel 4 kan være i forbindelse med behandling uten eget samtykke, (behandling med legemidler, eller behandling med tvungen ernæring ved alvorlig spiseforstyrrelse), eller bruk av tvangsmidler (mekaniske tvangsmidler herunder belter og 
remmer, kortvarig skjerming, enkeltstående bruk av korttidsvirkende legemidler eller kortvarig fastholding).

Helsedirektoratet i Norge har i 2010 utgitt en rapport, Samdata analyse IS-1861, "Bruk av tvang i psykisk helsevern for voksne i 2009».(6) Tallene nedenfor er hentet fra denne rapporten.

http://www.helsedirektoratet.no/publikasjoner/rapporter/bruk_av_ tvang_i_psykisk_helsevern_for_voksne_i_2009_774994

I denne rapporten presenteres analyser av omfanget av tvangsbruk innenfor det psykiske helsevernet. Det presenteres resultater basert på de data institusjonene har rapportert til Norsk pasientregister, en gjennomgang av kontrollkommisjonenes arbeid, av fylkesmennenes behandling av klager på vedtak om tvangsmedisinering og en oppsummering av kontrollkommisjonenes merknader vedrørende pasientenes generelle velferd.

Beregninger basert på pasientdata fra NPR viser at om lag 5000 personer ble tvangsinnlagt til sammen 7200 ganger i 2009. Dette tilsvarer 135 tvangsinnlagte personer og 192 tvangsinnleggelser per 100000 voksne innbyggere og utgjør 20 prosent av personene som ble behandlet i det psykiske helsevernet for voksne og 16 prosent av alle døgnopphold.

79 prosent av de tvangsinnlagte personene ble tvangsinnlagt en gang, mens 4 prosent ble tvangsinnlagt fire eller flere ganger. Halvparten av tvangsinnleggelsene var en innleggelse til tvungen observasjon, og tvungent psykisk helsevern med døgnopphold ble vurdert til å være nødvendig for en av fem observasjonsopphold. Ved utskrivning ble det fattet vedtak om videre tvungen oppfølging utenfor institusjon for hver tredje tvangsinnleggelse.

Data for 2009 viser at det er flest menn som tvangsinnlegges, og at 10 prosent av de tvangsinnlagte er 70 år eller eldre. Schizofreni spektrum lidelser, affektive lidelser og stoffrelaterte lidelser er de vanligste hoveddiagnosene blant tvangsinnlagte pasienter. 38 prosent av de tvangsinnlagte pasientene og 67 prosent av pasientene utskrevet til tvungent ettervern var diagnostisert med en schizofrenidiagnose.

Analysene viser betydelig variasjon i omfanget av tvangsinnleggelser. De nordlige områder av landet hadde flest tvangsinnleggelser i forhold til antall innbyggere i opptaksområdet, men det var store forskjeller mellom områdene i regionen. For hele landet varierte antall tvangsinnleggelser per 100000 voksne innbyggere fra 94 i de områdene der det ble benyttet minst tvang, til 306 der det ble benyttet mest.

Det er en målsetting å redusere omfanget av tvangsbruk innenfor det psykiske helsevernet i Norge. Helse- og omsorgsdepartementet har pålagt de regionale helseforetakene og Helsedirektoratet å utarbeide forpliktende handlingsplaner for redusert og riktig bruk av tvang i de psykiske helsetjenestene. 


\begin{tabular}{|c|c|c|c|c|}
\hline Tvangsinnleggelser & $\begin{array}{r}\text { Antall innleggel- } \\
\text { ser i psykiatriske } \\
\text { avdelinger }\end{array}$ & $\begin{array}{r}\text { Antall tvangsinn- } \\
\text { lagte pasienter } \mathrm{i} \\
\text { psykiatriske } \\
\text { avdelinger }\end{array}$ & $\begin{array}{r}\text { Antall tvangsinn- } \\
\text { lagte personer pr } \\
100.000 \text { voksne } \\
\text { innbyggere }\end{array}$ & $\begin{array}{r}\text { Prosent av persone- } \\
\text { ne som ble behand- } \\
\text { let i det psykiske } \\
\text { helsevernet for } \\
\text { voksne }\end{array}$ \\
\hline 2005 & 7290 & & & \\
\hline 2006 & 6941 & & & \\
\hline 2007 & 6764 & & & \\
\hline 2008 & 7300 & 5032 & & \\
\hline 2009 & 7203 & 5050 & 135 & 20 \\
\hline
\end{tabular}

Kilde: Samdata analyse IS-1861, «Bruk av tvang i psykisk helsevern for voksne i 2009».

Tabellen viser antall innleggelser (eksklusive overføringer) og pasienter med vedtak om tvungen observasjon eller tvungent psykisk helsevern. Estimerte tall. Døgnbehandling i det psykiske helsevernet for voksne 2005 til 2009.

Beregninger viser at det i 2009 var ca 2250 utskrivninger til tvungent psykisk helsevern uten døgnopphold (TUD). Det ble fattet vedtak om TUD for om lag 1 av 3 tvangsinnleggelser totalt (dvs både observasjon/TPH) i 2009.

\section{Tvangsbehandling, mekaniske tvangsmidler, korttidsvirkende legemidler og isolering}

En gjennomgang og kontroll av de rapporterte dataene om bruk av tvangsmidler og tvangsbehandling innen psykisk helsevern viser at de innrapporterte dataene til SSB og Norsk Pasientregister ikke vurderes som pålitelige nok til at de kan publiseres på nasjonalt nivå (7). Gjennom Norges Forskningsråds evaluering av Opptrappingsplanen for psykisk helse har SINTEF Helse utført særskilte kartlegginger av bruken av tvangsmidler og skjerming i det psykiske helsevernet, i perioden 2001-2007. Alle data som gjengis her er hentet fra den siste av disse kartleggingene (8).

I følge disse kartleggingene økte bruken av mekaniske tvangsmidler fram til 2005, men har siden avtatt. Bruken av korttidsvirkende legemidler har variert fra år til år, men med en svak økning i antall pasienter som har blitt utsatt for dette. Bruken av isolat sank kraftig i begynnelsen av perioden, og har nå et ubetydeligt omfang. Nedenfor gis det en tabellarisk oversikt over utviklingen i bruken av de ulike formene for tvangsmidler i perioden 2001-2007. 
Tabell 2.8.4. Utviklingen i bruk av mekaniske tvangsmidler 2001-2007

\begin{tabular}{lrrr}
\hline Årstall & Pasienter & Ganger & Timer \\
\hline 2001 & 807 & 3347 & 27375 \\
2003 & 952 & 3746 & 23792 \\
2005 & 1118 & 5130 & 40440 \\
2007 & 967 & 4123 & 34406 \\
Pst endring 01-03 & 18 & 12 & -13 \\
Pst endring 03-05 & 17 & 37 & 70 \\
Pst endring 05-07 & -14 & -20 & -15 \\
Pst endring 01-07 & 20 & 23 & 26
\end{tabular}

Kilde: Bremnes R, Hatling T, Bjørngaard JH. Bruk av tvangsmidler i psykisk helsevern i 2001, 2003, 2005 og 2007. Trondheim: SINTEF Helse; 2008.

Tabell 2.8.5. Utviklingen i bruk av korttidsvirkende legemidler 2001-2007

\begin{tabular}{lrr}
\hline Årstall & Pasienter & Ganger \\
\hline 2001 & 593 & 2118 \\
2003 & 593 & 1314 \\
2005 & 820 & 2146 \\
2007 & 736 & 1804 \\
Pst endring 01-03 & 0 & -38 \\
Pst endring 03-05 & 38 & 63 \\
Pst endring 05-07 & -10 & -16 \\
Pst endring 01-07 & 24 & -15 \\
\hline
\end{tabular}

Kilde: Bremnes R, Hatling T, Bjørngaard JH. Bruk av tvangsmidler i psykisk helsevern i 2001, 2003, 2005 og 2007. Trondheim: SINTEF Helse; 2008.

Tabell 2.8.6. Utviklingen i bruk av isolering 2001-2007

\begin{tabular}{lrrr}
\hline Årstall & Pasienter & Ganger & Timer \\
\hline 2001 & 33 & 829 & 906 \\
2003 & 42 & 236 & 314 \\
2005 & 33 & 184 & 557 \\
2007 & 68 & 175 & 216 \\
Pst endring 01-03 & 27 & -72 & -65 \\
Pst endring 03-05 & -21 & -22 & 77 \\
Pst endring 05-07 & 106 & -5 & -61 \\
Pst endring 01-07 & 106 & -79 & -76
\end{tabular}

Kilde: Bremnes R, Hatling T, Bjørngaard JH. Bruk av tvangsmidler i psykisk helsevern i 2001, 2003, 2005 og 2007. Trondheim: SINTEF Helse; 2008.

\subsubsection{Sverige}

\section{Registrering av tvångsvård och tvångsåtgärder i Sverige}

I början av 2007 föreslogs att patientregistret i egenskap av ett hälsodata-register, skulle utvidgas med individbaserade tvångsvårdsuppgifter, dvs. uppgifter om patienter inskrivna för sluten eller öppen psykiatrisk tvångsvård enligt lagen (1991:1128) om psykiatrisk tvångsvård (LPT) eller lagen (1991:1129) om rättspsykiatrisk vård (LRV). Huvudsyftet var att förbättra tvångsvårdsstatistiken, med en målsättning att få ett väl fungerande register för psykiatrisk tvångsvård, med start från årsskiftet 2008/2009. Sveriges landsting skall tre gånger årligen rapportera uppgifterna till Socialstyrelsen. 
Under 2008 bedrevs även ett omfattande arbete för att utvidga patient-registrets föreskrift. En förändring av föreskriften var nödvändig för att möjliggöra inrapportering av nya variabler om psykiatrisk tvångsvård.

Den 1 januari 2009 trädde den nya föreskriften (SOSFS 2009:26) i kraft. Under 2009 rapporterade totalt 16 landsting in tvångsvårdsuppgifter till patientregistret. 2010 är det år då samtliga landsting rapporterat till Socialstyrelsen.

Nedanstående redovisning i tabell 2.8.7. bygger på uppgifter som inrapporterats till patientregistret avseende psykiatrisk tvångsvård för 2010. I redovisningen ingår endast avslutade vårdtillfällen. Totalt hade 11611 patienter skrivits ut efter psykiatrisk slutenvård enligt LPT eller LRV under 2010, vilket innebär ca 22 procent av samtliga utskrivningar. I tabell 2.8.8. finns förekomsten av tre typer av tvångsåtgärder redovisade. För ca. 2100 personer användes minst en av dessa tre typer av tvångsåtgärder.

Tabell 2.8.7. Förekomst av tvångsvård enligt LPT eller LRV år 2010

\begin{tabular}{lrrr}
\hline Kön & $\begin{array}{r}\text { Utskrivna patienter vår- } \\
\text { dade enligt LPT eller LRV } \\
\mathbf{2 0 1 0}\end{array}$ & $\begin{array}{r}\text { Totalt antal utskrivna } \\
\text { patienter i psykiatrisk } \\
\text { slutenvård 2010 }\end{array}$ & $\begin{array}{r}\text { Andel tvångsvårdade i } \\
\text { relation till all psykiatrisk } \\
\text { slutenvård 2010 }\end{array}$ \\
\hline Kvinnor & 5584 & 24823 & $22,5 \%$ \\
Män & 6027 & 27066 & $22,3 \%$ \\
Totalt & 11611 & 51889 & $22,4 \%$ \\
\hline
\end{tabular}

Kilde: Patientregistret, Socialstyrelsen

Tabell 2.8.8. Förekomst av tvångsåtgärder år 2010

\begin{tabular}{lrrrr}
\hline Kvinnor & Tvångsmedicinering & Fastspänning & Avskiljande & Minst en av tre \\
\hline Antal förekomster & 1953 & 1582 & 858 & \\
Antal patienter & 821 & 435 & 234 & 1041 \\
Antal per patient & 2,4 & 3,6 & 3,7 & \\
\hline \multirow{2}{*}{ Män } & Tvångsmedicinering & Fastspänning & Avskiljande & \multirow{2}{*}{ Minst en av tre } \\
\hline \multirow{2}{*}{ Antal förekomster } & 1415 & 1279 & 1082 & \\
Antal patienter & 708 & 546 & 346 & 1057 \\
Antal per patient & 2,0 & 2,3 & 3,1 & \\
\hline
\end{tabular}

Kilde: Patientregistret, Socialstyrelsen

\subsection{ECT-behandling (Electro Convulsive Therapy)}

I de nordiske lande er der forskelle i lovgrundlaget i relation til udførelse af ECT-behandling samt i relation til den kliniske håndtering heraf. $\mathrm{Ne}-$ denfor beskrives ECT-behandling i de forskellige nordiske lande.

\subsubsection{Danmark}

ECT-behandling i Danmark udføres på baggrund af psykiatrilovens bestemmelser: Bekendtgørelse nr. 1729 af 2. december 2010 af lov om anvendelse af tvang $\mathrm{i}$ psykiatrien (psykiatriloven) (1). http:// 
www.sst.dk/Planlaegning\%20og\%20kvalitet/Psykiatriomraadet/Tvang _i_psykiatrien.aspx.

Gemmenførelse af ECT-behandling beror på sygehusenes instrukser. Der er ikke dags dato nationale retningslinjer herfor, men Sundhedsstyrelsen har udgivet generel psykiatrivejledning for udformning af instrukser: Vejledning nr. 9001 af 20. november 2000.

ECT-behandling i Danmark foretages frivilligt, men kan udføres som tvangsbehandling ved svære livstruende psykiatriske tilstande hos patienter.

Der henvises i øvrigt til følgende rapporter:

- Behandling af depressionssygdomme - 2005 http://www.sst.dk/Planlaegning\%20og\%20kvalitet/Psykiatriomraa det/Depression.aspx

- Referenceprogram for unipolar depression,2007 http://www.sst.dk/publ/Publ2007/PLAN/SfR/SST_Dep.rapport.pdf

- Kommentering af: Behandling af depressionssjukdomar. En systematisk litteraturöversikt. Volym 1-3. Statens beredning för medicinsk utvärdering http://www.sst.dk/publ/Publ2005/CEMTV/KUMTV/KUMTVdepress ion.pdf

- Elektroconvulsiv terapi (ECT-behandling og dødsfald - en udredning, Sundhedsstyrelsen 2010 http://www.sst.dk/publ/Publ2010/TILSYN/ECT/ECTbehl_doed_udr edn.pdf

- Dansk Psykiatrisk Selskab har i 2011 udgivet en vejledning i ECTbehandling (9)

http://www.dpsnet.dk/fileadmin/user_upload/menu/publikationer /2011/DPS_ECT_vejledning_2011_med_T.pdf

Nedenfor er vejledningens informationer om ECT-behandling i Danmark beskrevet

\section{ECT-behandling i Danmark}

En række enqueteundersøgelser har vist, at man i Danmark, sammenlignet med andre lande, hyppigere anvender ECT i psykiatrisk behandling. Her skal omtales følgende undersøgelser: Heshe og Röder (1976), udført i 1972-73; Hedemand og Christensen (1982), udført i 1979; Strömgren (1991), udført i 1977 og gentaget i 1987; og endeligt den seneste, af Schröder og Christensen (1995), udført i 1991 (10,11,12,13).

Strömgrens undersøgelse, som omfatter de 5 nordiske lande: Sverige, Norge, Danmark, Finland og Island, viser, at behandlingen bruges noget mere i Sverige og Danmark end i de andre nordiske lande, men at der i øvrigt ikke er væsensforskelle i indikationsstillingen, når det gælder de enkelte diagnoser.

Sammenligner man på den ene side de nordiske lande, på den anden side USA, Storbritannien og Irland, ses det derimod, at der er ganske 
store forskelle i indikationsstillingen. Her spiller diagnostisk terminologi givetvis en rolle for de forskellige synspunkter med hensyn til brugen af ECT. For eksempel har et begreb som „endogen depression“ kunnet give anledning til forskelle i diagnostisk praksis, idet psykiatere i mange lande betragter denne lidelse som en afgrænset nosologisk enhed, medens andre betragter alle depressionsformer som elementer i et continuum, og kun differentierer imellem „minor depression“ og „major depression“, eller mellem „neurotisk“ og „psykotisk“ depression, som ud fra sådanne overvejelser ikke formodes at være ætiologisk forskellige.

Tilsvarende betragtes delirium acutum i Nordeuropa som en veldefineret (skønt ætiologisk heterogen) enhed, hvorimod den slet ikke forekommer i publikationer fra USA og UK, muligvis fordi den her er inkluderet i grupperne „catatonia“ og „schizophrenia“.

Siden ECT blev indført i Danmark i 1939, er der lavet 3 landsdækkende opgørelser over brugen af ECT i Danmark. De første to blev lavet af hhv. Hesche og Røder i 1975 (tal fra 73) og Hedemand og Christensen i 1983 (tal fra 79). Den 3. opgørelse er lavet i år 2000 med tal fra 1999 (Andersson og Bolwig, 2002).

I 1973 blev der givet 22.210 behandlinger til 3.438 patienter, i 1979 19.564 behandlinger til 2.332 patienter og i 199916.306 behandlinger til 1710 patienter, hvilket svarer til et fald på ca. $17 \%$ i antal behandlinger og $27 \%$ i antal patienter fra 79 til 99. Der er samtidig sket en stigning i antal behandlinger pr. patient fra 6,5 i gennemsnit i 1973 til 8,4 i 1979 og 9,5 i 1999.

Den præcise årsag til denne stigning i antal behandlinger pr. patient kendes ikke. Opgørelsen fra 1999 viste desuden, at indikationsområdet for ECT stort set er uændret fra 1979, dvs. depression er fortsat hovedindikationen for ECT efterfulgt af delir og mani.

Der er sket store fremskridt på det tekniske område, idet alle afdelinger nu bruger ECT-apparater som anvender konstant strøm, bidirektionel brief pulse square wave stimuli og med mulighed for eegmonitorering.

I 1979 havde kun 4 ud af 52 afdelinger sådanne apparater, de resterende benyttede sig af apparater med sinusformede stimulationspotentialer uden eeg-monitorering.

Mht. elektrodeplaceringen viste undersøgelsen for 1999, at de fleste afdelinger både brugte uni- og bilateral elektrodeplacering efterfulgt af udelukkende bilateral elektrodeplacering. Resultaterne af samtlige de undersøgelser er således entydige: De allerfleste afdelinger på begge sider af Storebælt anvender bilateral eller differentieret eletrodeplacering.

I gennemsnit fik $5 \%$ af alle døgnindlagte patienter ECT (2\%-10 \%) i 1999. Der er altså en spredning på en faktor 5 i brugen af ECT i DK. Årsagen til denne spredning kendes ikke, men behandlingstraditioner og patientsammensætning spiller sandsynligvis ind.

Siden 2003 har det været obligatorisk, at alle ECT-behandlinger registreres i Sundhedsstyrrelsen. Udfra de seneste års tal synes antallet af 
behandlinger at være stabiliseret på et niveau på ca. 19.500 enkeltbehandlinger til 1.840 patienter pr. år i DK (9).

\subsubsection{Finland}

Uppgifter om antal ECT-behandlingar på nationell nivå saknas i Finland. Vid en undersökning av två kohorter personer som erhållit invalidpension på grund av depression (åren 1993-1994 och 2003-2004) fann man att $4 \%$ i den äldre kohorten fătt ECT-behandling, men enbart 1,5 \% i den färskare kohorten. Detta tyder på ett en minskning av ECT-behandlingen skett 1993-2004. (Honkonen et al. 2007). Data från det största psykiatriska sjukhuset i Finland (Mariefors sjukhus) anger att inom sjukhusets upptagningsområde är använnds ECT för 17 personer/100 000 invånare/år (Ritschkoff \& Vataja 2009).

Den geografiska spridningen av ECT är ojämn, eftersom användningen är knuten till lokal praxis som varierar från sjukhus till sjukhus och mellan behandlande läkare. Under senare år har psykiatrar betonat behovet av att öka användningen av ECT (Ritschkoff \& Vataja 2009).

På nationell nivå saknas kliniska riktlinjer för ECT-behandling, men den nationella "God medicinsk praxis" riktlinjen för depression från 2010 rekommenderar användning av ECT vid svår eller psykotisk depression. Risken för långvariga minnesstörningar nämns inte i behandlingsrikt-linjen. (Finlands psykiaterförening 2010).

Lokalt har en del sjukhus sina egna rekommendationer och anvisningar $(14,15,16)$.

\subsubsection{Færøerne}

Færøerne har psykiatrilovens grundlag som hjemmel for udførelse af ECT-behandling (2).

\subsubsection{Grønland}

Behandling med ECT bliver i Grønland brugt ved svær depression, hvor medicinsk behandling ikke har haft effekt. Behandlingen ydes kun på Psykiatrisk afdeling på Dronning Ingrids Hospital i Nuuk. Der foreligger instruks for den praktiske udførelse af behandlingen.

\subsubsection{Island}

ECT-behandling er brugt hvor medicinsk behandling ikke har haft effekt. Behandlingen ydes kun på psykiatrisk afdeling på Landspítali Reykjvík. Der foreligger instruks for den praktiske udførelse af behandlingen. Behandlingen baseres på grund av samtykke fra patienten eller relativer, hvis patienten ikke kan give samtykke på grund av sin sygdom. 


\subsubsection{Norge}

Behandling med ECT må baseres på samtykke fra pasienten. ECT behandling kan ikke hjemles i phvl. § 4-4. I rundskriv til loven presiseres av ECT helt unntaksvis vil kunne hjemles i nødrett.

ECT-behandling har økt i omfang ved mange norske sykehus de senere årene. Det er vanlig å kun gi behandlingen til pasienter med alvorlig depresjon, som først har forsøkt ulike medikamenter uten å ha fătt effekt av dette. ECT gis under en kortvarig narkose.

Behandlingen gis som regel unilateralt, vanligvis med en elektrode på høyre side ved tinningen, og en elektrode øverst på hodet. Siden behandlingen består i å utløse et epileptisk lignende krampeanfall, må krampehemmende medikamenter som benzodiazepiner avsluttes på forhånd. Epilepsianfallet blir nøye overvåket av lege og sykepleier for å vurdere anfallets kvalitet og av anestesilege for å sikre hjerterytme og for eventuelt å avbryte anfallet med diazepam om det varer for lenge. Etter ECTserie fortsettes behandlingen med medikamenter, samtaleterapi og psykososiale tiltak.

ECT brukes i Norge på indikasjonen alvorlig depresjon, psykotisk depresjon og melankoli hos eldre. Det brukes også i enkelte tilfeller ved alvorlige postpartum-depresjoner som ikke responderer på annen behandling, og ved katatoni.

Vi har lite oversikt over omfanget av bruken, effekt, bivirkninger og langtidseffekt. Ut fra anestesiregistreringer synes antall behandlinger pr. år å ligge på ca 10000 . Hver behandlingsserie er ofte på 8-10 behandlinger. Vi har ikke kunnskap om det gis flere behandlinger til samme pasient i løpet av et år. Et forsiktig estimat er at ca 1000 personer årlig gjenomgår behandlingen.

En del pasienter får såkalt vedlikeholdsbehandling over lengre tid, men vi har lite oversikt over dette. Slik vedlikeholdsbehandling er omdiskutert, og slik behandling anbefales ikke som vedlikeholdsterapi ved depresjon.

ECT benyttes kun med pasientens samtykke, det kan ikke gis under tvang.

Det er imidlertid ulik praksis angående om man innhenter skriftlig samtykke før behandlingen. Det er også beskrevet at behandlingen gis som nødrett ved livstruende katatoni med uttalt næringsvegring. Det er imidlertid ingen oversikt over denne bruken.

I Norge gjøres det for tiden en kunnskapsoppsummering av Kunnskapssenteret. Denne oppsummeringen er bebudet ferdig i løpet av 2011, og vil være en gjennomgang av internasjonale studier om ECT ved depresjon og bipolare lidelser, og vil således ikke gi mer kunnskap om bruken i Norge. Kunnskapssenteret vil publisere en oversikt bl a på bruken av bilaterale elektodebruk kontra unilateral og en rapport om kognitiv fungering etter ECT behandling. 
Metoden er omdiskutert, og flere brukere og brukerorganisasjoner i Norge har stått fram med kritikk av behandlingen og rapportert om kognitive bivirkninger.

Det har fra Helsedirektoratet vært tatt initiativ for å få til bedre registrering av bruken. ECT behandling er beskrevet i en prosedyrekode som skal kodes i prosedyrekodeverket som er gjort obligatorisk for psykisk helsevern fra 01.09.10, men denne kodingen er foreløpig svært ufullstendig. Helsedirektoratet vurderer at det er behov for å kartlegge bruken av ECT og vurderer å utarbeide et nasjonalt register. Det er behov for å utarbeide retningslinjer for behandling med ECT. Disse bør belyse indikasjon og praktisk utførelse, men også etiske og juridiske problemstillinger, virkninger, bivirkninger, langtidseffekt og pasientsikkerhet.

\subsubsection{Sverige}

Socialstyrelsen publicerade år 2010 Nationella riktlinjer för vård vid depression- och ångestsyndrom. I dessa ingår rekommendationer kring ECT-behandling vid depressionsjukdomar. Bland annat framgår att vid svår egentlig depression bör hälso- och sjukvården erbjuda:

- elektrokonvulsiv behandling (ECT) (prioritet 3)

När snabb effekt är nödvändig bör hälso- och sjukvården erbjuda:

- elektrokonvulsiv behandling (ECT) (prioritet 1).

Prioriteringarna görs på en skala mellan 1-10 där 1 innebär högsta prioritet. För att kunna följa upp detta har en indikator formulerats:

- Indikator: ECT-behandling vid svår till mycket svår egentlig depressionsepisod.

Motivering till indikatorn är att det finns stark evidens för att ECT har god till mycket god effekt vid behandling av svår till mycket svår egentlig depressionsepisod

I rapporten "Öppna jämförelser och utvärdering 2010. Psykiatrisk vård" konstaterades att det inte går att följa upp ECT-behandling på grund av bristande inrapportering till patientregistret trots att det finns lagstöd för att alla åtgärder ska registreras. Enligt en särskild lag ska all behandling (inkl. ECT-behandling) under tvångsvård rapporteras. Bristerna i registreringen har Socialstyrelsen vid ett flertal tillfällen påtalat till landstingen som ansvarar för detta.

Hösten 2011 förväntas Socialstyrelsen kunna ha bättre tillgång till data kring ECT-behandling både inom ramen för tvångsvård resp annan psykiatrisk vård. Socialstyrelsen har även ett övergripande uppdrag från 
regeringen att utveckla en modell för verksamhetsuppföljning inom det psykiatriska området.

I rapporten konstaterades även att det finns ett regionalt kvalitetsregister för ECT-behandling sedan 2008. Under 2011 kommer ett nationellt kvalitetsregister att starta.

\subsection{Nationale kliniske retningslinjer og nationale registre i de nordiske lande}

I dette afsnit gives en oversigt over de nationale kliniske retningslinjer og nationale registre, som findes i de enkelte nordiske lande for nogle af de psykiatriske sygdomme.

Tabel 2.10.1 Nationale kliniske retningslinjer og registre vedr. skizofreni (børn- og unge)

\begin{tabular}{lll}
\hline & Nationale kliniske retningslinjer & Nationale registre \\
\hline Danmark & Nej & $\begin{array}{l}\text { NIP-skizofreni (børn og unge): } \\
\text { http://www.nip.dk/files/Subsites/NIP/Skizofr } \\
\text { eni/20091201_Indikatorskema_BogU.PDF } \\
\text { http://www.psykiatriskgrundforskning.dk/reg } \\
\text { istre/psykiatrisk-centralregister/ }\end{array}$ \\
& & Nej \\
Finland & Ja & \\
& http://www.kaypahoito.fi/web/kh/suositukse & \\
& t/naytaartikkeli/tunnus/hoi35050 & \\
& http://www.kaypahoito.fi/web/svenska/patie & \\
Færøerne & nter/naytaartikkeli/tunnus/khr00004 & Nej \\
Grønland & (svenska) & Nej \\
Island & Nej & Nej \\
Norge & Nej & Nej \\
& Ja. «Schizofreni. Kliniske retningslinjer for & \\
& utredning og behandling.» Utgitt av Statens & \\
& helsetilsyn 2000. Nye Nasjonale retningslinjer & \\
& for utredning, behandling og oppfølging av & \\
psykoselidelser er under utarbeidelse, & \\
& ferdigstilles i løpet av 2011/2012. & Natioenellt patientregister där slutenvård och \\
Sverige & Nej & läkarbesök i öppenvård ingår \\
& &
\end{tabular}


Tabel 2.10.2. Nationale kliniske retningslinjer og registre vedr. skizofreni (voksne)

\begin{tabular}{|c|c|c|}
\hline & Nationale kliniske retningslinjer & Nationale registre \\
\hline Danmark & $\begin{array}{l}\text { Ja, Referenceprogram for skizofreni } 2004 . \\
\text { http://www.sst.dk/publ/Publ2004/RefprogSk } \\
\text { izo.pdf }\end{array}$ & $\begin{array}{l}\text { Ja, NIP-skizofreni (voksne) Link: } \\
\text { http://www.nip.dk/files/Subsites/NIP/Skizofr } \\
\text { Ski/2010_Indikatorskema_skizofreni_voksnv. } \\
\text { pdf } \\
\text { http://www.psykiatriskgrundforskning.dk/reg } \\
\text { istre/psykiatrisk-centralregister/ }\end{array}$ \\
\hline Finland & $\begin{array}{l}\text { Ja } \\
\text { http://www.kaypahoito.fi/web/kh/suositukse } \\
\text { t/naytaartikkeli/tunnus/hoi35050) } \\
\text { http://www.kaypahoito.fi/web/svenska/patie } \\
\text { nter/naytaartikkeli/tunnus/khr00004 } \\
\text { (svenska) }\end{array}$ & Nej \\
\hline Færøerne & Nej & Nej \\
\hline Grønland & Ja & Nej \\
\hline Island & Nej & Nej \\
\hline Norge & $\begin{array}{l}\text { Ja. «Schizofreni. Kliniske retningslinjer for } \\
\text { utredning og behandling.» Utgitt av Statens } \\
\text { helsetilsyn } 2000 \text {. Nye Nasjonale retningslinjer } \\
\text { for utredning, behandling og oppfølging av } \\
\text { psykoselidelser er under utarbeidelse, } \\
\text { ferdigstilles i løpet av 2011/2012. }\end{array}$ & Nej \\
\hline Sverige & $\begin{array}{l}\text { Ja, för nationella riktlinjer för psykosociala } \\
\text { insatser } \\
\text { http://www.socialstyrelsen.se/Lists/Artikelka } \\
\text { talog/Attachments/18217/2011-1-3.pdf. } \\
\text { Svensk psykiatrisk förening har givit ut } \\
\text { kliniska riktlinjer } \\
\text { http://www.svenskpsykiatri.se/Riktlinjer/rp_s } \\
\text { chizofreni_tryck.pdf }\end{array}$ & $\begin{array}{l}\text { Nationellt patientregister med data om } \\
\text { slutenvård där schiz ingår, läkarbesök i } \\
\text { psykiatrisk öppenvård finns. Kvalitetsregister } \\
\text { för psykoser med låg täckningsgrad finns } \\
\text { (kvalitetsregister är frivilligt baserade) } \\
\text { http://www.kcp.se/vara_kvalitetsregister/ }\end{array}$ \\
\hline
\end{tabular}

Tabel 2.10.3. Nationale kliniske retningslinjer og registre vedr. depression

\begin{tabular}{|c|c|c|}
\hline & Nationale kliniske retningslinjer & Nationale registre \\
\hline Danmark & $\begin{array}{l}\text { Ja, Referenceprogram for unipolar depression } \\
\text { hos voksne - 2007. Link: } \\
\text { http://www.sst.dk/publ/Publ2007/PLAN/SfR/ } \\
\text { SST_Dep.rapport.pdf }\end{array}$ & $\begin{array}{l}\text { Ja, NIP-depression. Link: } \\
\text { http://www.nip.dk/forside/sygdomsomr\%c3 } \\
\text { \%a5der/depression/indikators\%c3\%a6t/indik } \\
\text { atorskema } \\
\text { http://www.psykiatriskgrundforskning.dk/reg } \\
\text { istre/psykiatrisk-centralregister/ }\end{array}$ \\
\hline Finland & $\begin{array}{l}\text { Ja } \\
\text { http://www.kaypahoito.fi/web/kh/suositukse } \\
\text { t/naytaartikkeli/tunnus/hoi50023 } \\
\text { http://www.kaypahoito.fi/web/english/sum } \\
\text { maries/naytaartikkeli/tunnus/ccs00062 (in } \\
\text { English) }\end{array}$ & Nej \\
\hline Færøerne & Nej & $\mathrm{Nej}$ \\
\hline Grønland & $\mathrm{Ja}$ & Nej \\
\hline Island & Nej & Nej \\
\hline Norge & $\begin{array}{l}\text { Ja Nasjonale retningslinjer for diagnostisering } \\
\text { og behandling av voksne med depresjon i } \\
\text { primær-og spesialisthelsetjenesten. ( IS- } \\
\text { 1561. Utgitt av Helsedirektoratet 2009). } \\
\text { http://www.helsedirektoratet.no/publikasjon } \\
\text { er/nasjonale_faglige_retningslinjer/nasjonale } \\
\text { _retningslinjer_for_diagnostisering_og_beha } \\
\text { ndling_av_voksne_med_depresjon_i_prim_r_- } \\
\text { _og_spesialisthelsetjenesten_443184 }\end{array}$ & Nej \\
\hline Sverige & $\begin{array}{l}\text { Ja } \\
\text { http://www.socialstyrelsen.se/Lists/Artikelka } \\
\text { talog/Attachments/17948/2010-3-4.pdf }\end{array}$ & $\begin{array}{l}\text { Nationellt patientregister med data om } \\
\text { slutenvård, läkarbesök i psykiatrisk öppen- } \\
\text { vård (inte primärvård) finns }\end{array}$ \\
\hline
\end{tabular}


Tabel 2.10.4. Nationale kliniske retningslinjer og registre vedr. bipolar lidelse

\begin{tabular}{|c|c|c|}
\hline & Nationale kliniske retningslinjer & Nationale registre \\
\hline Danmark & Nej & $\begin{array}{l}\text { Ja, } \\
\text { http://www.psykiatriskgrundforskning.dk/reg } \\
\text { istre/psykiatrisk-centralregister/ }\end{array}$ \\
\hline Finland & $\begin{array}{l}\text { Ja } \\
\text { http://www.kaypahoito.fi/web/kh/suositukse } \\
\text { t/naytaartikkeli/tunnus/hoi50076 }\end{array}$ & Nej \\
\hline Færøerne & Nej & Nej \\
\hline Grønland & $\mathrm{Ja}$ & Nej \\
\hline Island & Nej & Nej \\
\hline Norge & $\begin{array}{l}\text { Nasjonale retningslinjer for utredning og } \\
\text { behandling av bipolare lidelser er under } \\
\text { utarbeidelse, ferdigstilles i løpet av } 2011 . \\
\text { (Erstatter: Stemningslidelser. Kliniske ret- } \\
\text { ningslinjer for utredning og behandling. Utgitt } \\
\text { av Statens helsetilsyn 2000). }\end{array}$ & Nej \\
\hline Sverige & $\begin{array}{l}\text { Ja } \\
\text { http://www.socialstyrelsen.se/Lists/Artikelka } \\
\text { talog/Attachments/17948/2010-3-4.pdf }\end{array}$ & $\begin{array}{l}\text { Nationellt patientregister med data om } \\
\text { slutenvård, läkarbesök i psykiatrisk öppen- } \\
\text { vård (inte primärvård) finns. Kvalitetsregister } \\
\text { med begränsad täckningsgrad finns (kvalitets- } \\
\text { register är frivilligt baserade) } \\
\text { http://www.kcp.se/vara_kvalitetsregister/ }\end{array}$ \\
\hline
\end{tabular}

Tabel 2.10.5. Nationale kliniske retningslinjer og registre vedr. ADHD

\begin{tabular}{|c|c|c|}
\hline & Nationale kliniske retningslinjer & Nationale registre \\
\hline Danmark & $\begin{array}{l}\text { Ja, Referenceprogram for udredning og } \\
\text { behandling af børn og unge med ADHD - } \\
\text { april } 2008 \text {. } \\
\text { http://www.bupnet.dk/media/ADHDReferen } \\
\text { ceprogram080508_jb[1].pdf }\end{array}$ & $\begin{array}{l}\text { Ja, } \\
\text { http://www.psykiatriskgrundforskning.dk/regi } \\
\text { stre/psykiatrisk-centralregister/ } \\
\text { Ja }\end{array}$ \\
\hline Finland & $\begin{array}{l}\text { Ja } \\
\text { http://www.kaypahoito.fi/web/kh/suosituks } \\
\text { et/naytaartikkeli/tunnus/hoi50061 (finska) } \\
\text { http://www.kaypahoito.fi/web/svenska/pati } \\
\text { enter/naytaartikkeli/tunnus/khr00068 } \\
\text { (svenska) }\end{array}$ & Nej \\
\hline Færøerne & Nej & Nej \\
\hline Grønland & Nej, børnepsykiatri leveres fra Danmark & Nej \\
\hline Island & $\begin{array}{l}\text { Island har national vejleder i diagnostik og } \\
\text { behandling af ADHD. }\end{array}$ & Nej \\
\hline Norge & $\begin{array}{l}\text { Veileder i diagnostikk og behandling av } \\
\text { ADHD. Diagnostikk og behandling av hyper- } \\
\text { kinetiske forstyrrelse/attention deficit } \\
\text { hyperactivity disorder (AD/HD) hos barn, } \\
\text { ungdom og voksne. ( IS-1244. Utgitt av } \\
\text { Sosial- og helsedirektoratet 2005. Er under } \\
\text { revidering til nasjonale retningslinjer, ferdig- } \\
\text { stilles i løpet av 2011). } \\
\text { http://www.helsedirektoratet.no/publikasjo } \\
\text { ner/veiledere/veileder_for_diagnostisering_- } \\
\text { og_behandling_av_ad_hd_33281 }\end{array}$ & Nej \\
\hline Sverige & Nej & $\begin{array}{l}\text { Nationellt patientregister med data om } \\
\text { slutenvård, läkarbesök i psykiatrisk öppenvård } \\
\text { (inte primärvård)finns. Kvalitetsregister med } \\
\text { låg täckningsgrad finns(kvalitetsregister är } \\
\text { frivilligt baserade) } \\
\text { http://www.kcp.se/vara_kvalitetsregister/ }\end{array}$ \\
\hline
\end{tabular}




\subsection{Hovedresultater af patient- og pårørendeenqueter}

I dette afsnit vises resultater fra de patient- og pårørende enqueter, som Danmark, Norge og Sverige gennemfører hvert eller hvert andet år. Færøerne, Grønland og Island gennemfører ikke tilbagevendende årlige patienttilfredshedsundersøgelser. Finland udfører tilfredshedsunders $\emptyset$ gelser, men har ikke bidraget til dette afsnit.

\subsubsection{Danmark}

I det danske sundhedsvæsen gennemføres patienttilfredshedsundersøgelser blandt indlagte og ambulante patienter, samt for patienter i distriktpsykiatrien. Ligeledes gennemføres der i relation til disse undersøgelser såkaldte pårørende tilfredshedsundersøgelser, der har til formål at belyse pårørendes kontakt til psykiatrien. Disse undersøgelser er hidtil gennemført hvert 3. år, men det planlægges at gennemføre disse undersøgelser hvert år.

De danske patient- og pårørendetilfredshedsundersøgelser, som præsenteres i afsnittet, omhandler dels børne- og ungdomsspykiatri i dag- og døgnafsnit, hospitalspsykiatri, samt distriktpsykiatrien $(17,18,19)$.

\section{Børne og ungdomsspykiatri}

Fra den 1. august 2007 til den 30. september 2008 fik 646 patienter fra 16 børne- og ungdomspsykiatriske dag- og døgnafsnit i Danmark udleveret et spørgeskema. 493 patienter besvarede skemaet. På landsplan var undersøgelsens svarprocent dermed på 76. Det var meget tilfredsstillende for en undersøgelse af denne karakter.

En bortfaldsanalyse blandt patienter viste, at svarpersonerne var repræsentative for de patienter, der fik tilbudt et spørgeskema.

Box 1: Patienterne blev bedt om at give deres samlede indtryk af indlæggelsen gennem tildeling af 1-5 stjerner:

- 5 stjerner: enestående

- 4 stjerner: godt

- 3 stjerner: både godt og dårligt

- 2 stjerner: dårligt

- 1 stjerne: uacceptabelt 


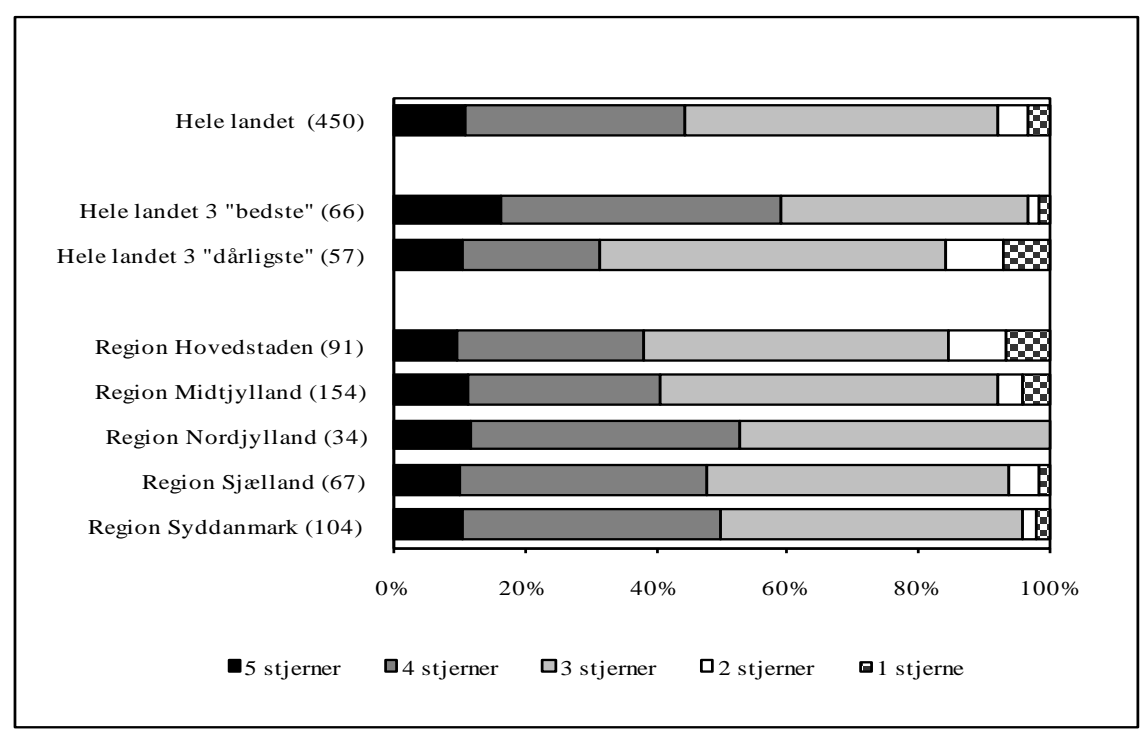

Figur 2.5: Hvad er dit samlede indtryk af indlæggelsen

Kilde. Patienterne og deres forældre har ordet. Unders $\varnothing$ gelse i de børne- og ungdomspsykiatriske dag- og døgnafsnit i Danmark 2007-08, Center for Kvalitetsudvikling, marts 2009.

Der var betydelige variationer i patienttilfredsheden inden for de enkelte børne- og ungdomspsykiatriske afsnit.

Blandt besvarelserne fra afsnittene blev det analyseret, hvordan patienternes $k ø n$, ventetid, længde af indlæggelse og anvendelse af tvang påvirkede svarpersonernes samlede vurdering af afsnittet. Baggrundsforholdene blev taget i betragtning samtidigt i én samlet analyse.

Det, der blandt disse forhold påvirkede besvarelserne, var patienternes køn, hvor piger var signifikant mindre tilfredse end drenge.

Patienter, der blev brugt tvang over for under indlæggelsen, var signifikant mindre tilfredse end patienter, der ikke oplevede tvang under indlæggelsen.

Patienterne blev spurgt, hvordan indlæggelsen var i forhold til de forventninger de havde på forhånd. Figuren nedenfor viser dette. 


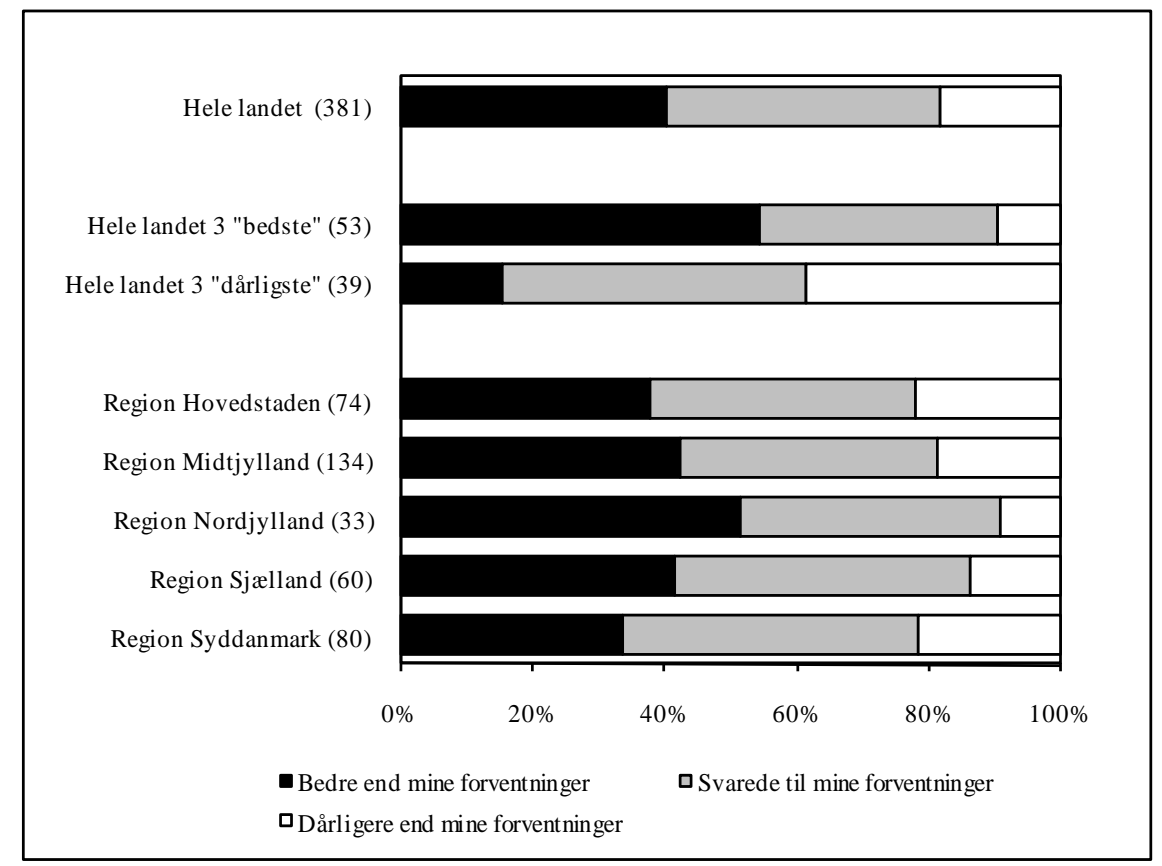

Figur 2.6: Indlæggelsen i forhold til forventninger

Kilde. Patienterne og deres forældre har ordet. Unders $\varnothing$ gelse i de børne- og ungdomspsykiatriske dag- og døgnafsnit i Danmark 2007-08, Center for Kvalitetsudvikling, marts 2009.

I figuren nedenfor vises landsresultatet for de øvrige spørgsmål, der vedrører patientens kontakt med afsnittet. Spørgsmålene er sorteret efter tilfredshed. 


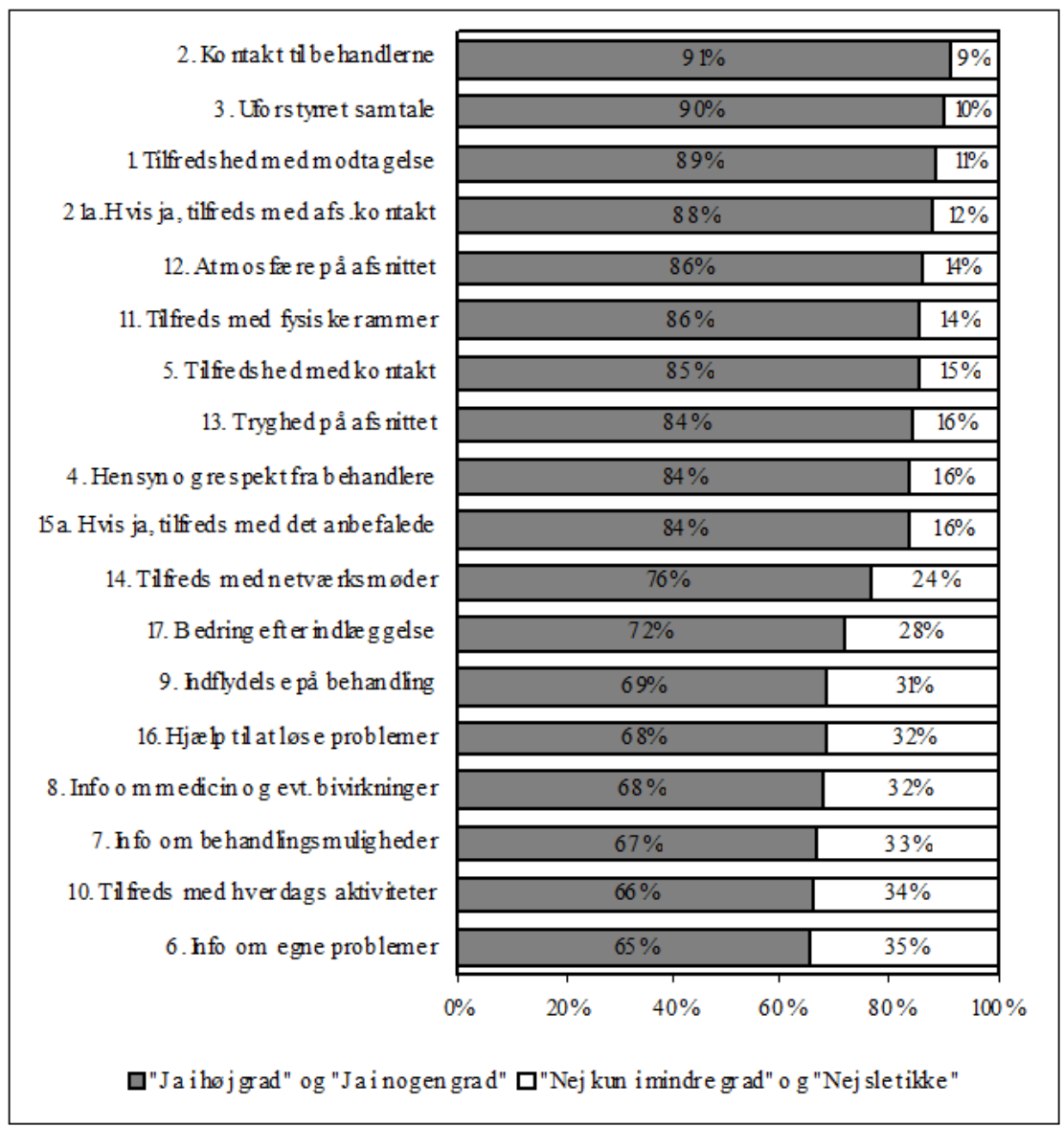

\section{Figur 2.7: Øvrige spørgsmål om tilfredshed}

Kilde: Patienterne og deres forældre har ordet. Unders $\varnothing$ gelse i de børne- og ungdomspsykiatriske dag- og døgnafsnit i Danmark 2007-08, Center for Kvalitetsudvikling, marts 2009.

\section{Forældreundersøgelsen (børne- og ungdomsspykiatri)}

Fra den 1. august 2007 til 30. september 2008 fik 1.153 forældre til børn fra 33 børne- og ungdomspsykiatriske dag- og døgnafsnit i Danmark udleveret et spørgeskema. 673 forældre besvarede skemaet. På landsplan var undersøgelsens svarprocent dermed på 58. Det var acceptabelt for en undersøgelse af denne karakter.

En bortfaldsanalyse blandt forældre viste, at svarpersonerne var repræsentative for de forældre, der fik tilbudt et spørgeskema.

Forældrene blev bedt om at give deres samlede indtryk af indlæggelsen gennem tildeling af 1-5 stjerner, jævnfør Box 1. 


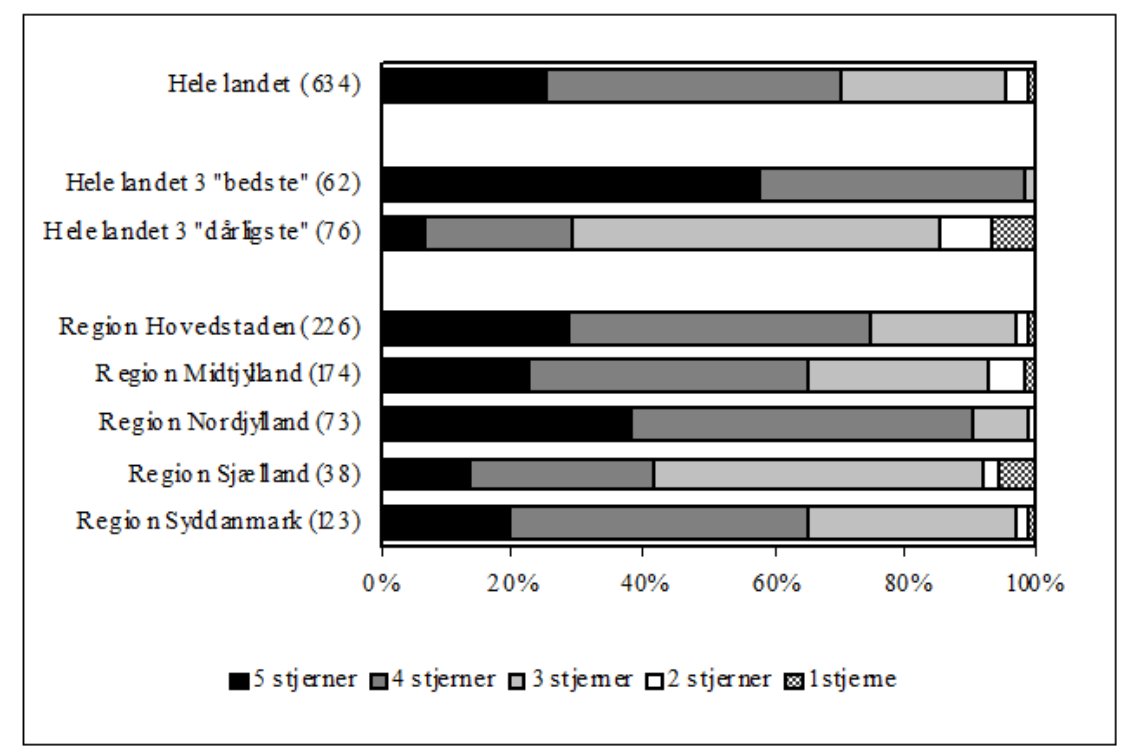

Figur 2.8: Samlede indtryk af indlæggelsen

Kilde. Patienterne og deres forældre har ordet. Undersøgelse i de børne- og ungdomspsykiatriske dag- og døgnafsnit i Danmark 2007-08, Center for Kvalitetsudvikling, marts 2009.

Der var forholdsvis store variationer i tilfredsheden inden for de enkelte børne- og ungdomspsykiatriske afsnit.

Blandt besvarelserne fra afsnittene blev det analyseret, hvordan patientens køn, patientens alder, ventetid, indlæggelseslængde, anvendelse af tvang og forældrenes antal kontakter med afsnittet påvirkede svarpersonernes samlede vurdering af afsnittet. Baggrundsforholdene blev taget i betragtning samtidigt i én samlet analyse.

Det, der blandt disse forhold påvirkede besvarelserne, var patientens køn, hvor forældre til piger var signifikant mindre tilfredse end forældre til drenge.

Forældre til patienter på 15 år og derover var signifikant mindre tilfredse end forældre til patienter på 0-7 år.

Forældre til patienter der havde oplevet tvang var signifikant mindre tilfredse end forældre til patienter, der ikke havde oplevet tvang.

Forældre der havde haft mere end 4 kontakter var signifikant mere tilfredse end forældre der havde haft 1-4 kontakter med afsnittet.

Forældrene blev spurgt, hvordan indlæggelsen var i forhold til de forventninger de havde på forhånd. Figuren nedenfor viser dette. 


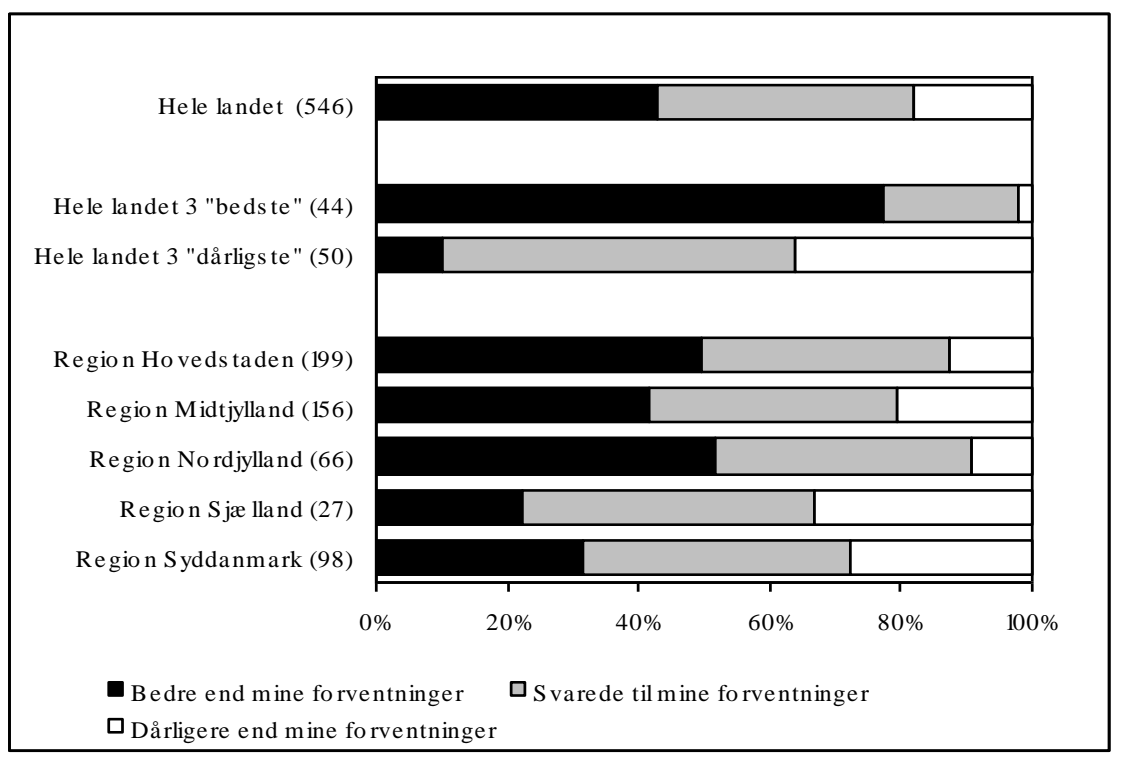

Figur 2.9: Indlæggelsen i forhold til forventninger

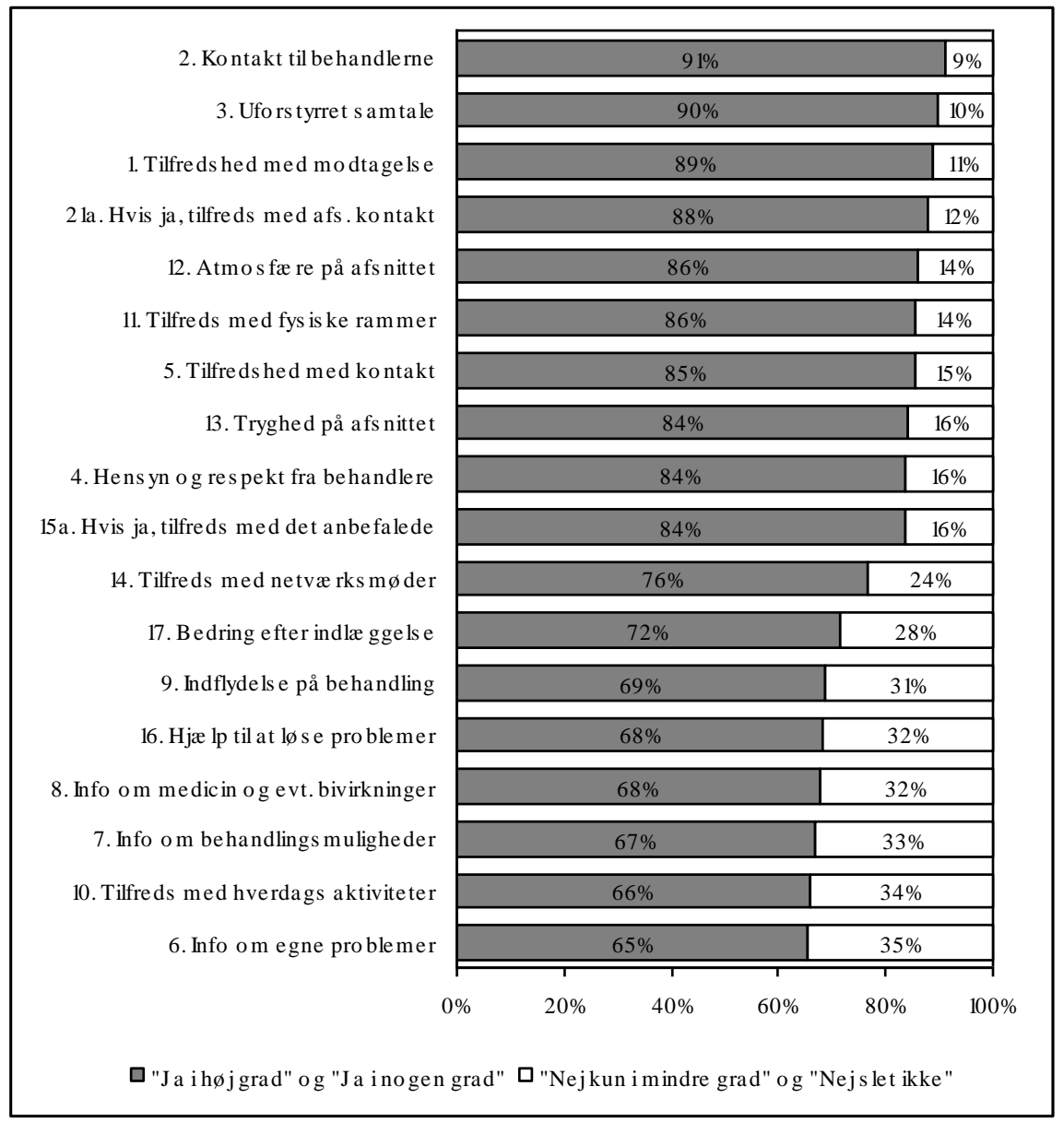

Figur 2.10: Øvrige spørgsmål om tilfredshed

Kilde. . Patienterne og deres forældre har ordet. Unders $\emptyset$ gelse i de børne- og ungdomspsykiatriske dag- og døgnafsnit i Danmark 2007-08, Center for Kvalitetsudvikling, marts 2009. 


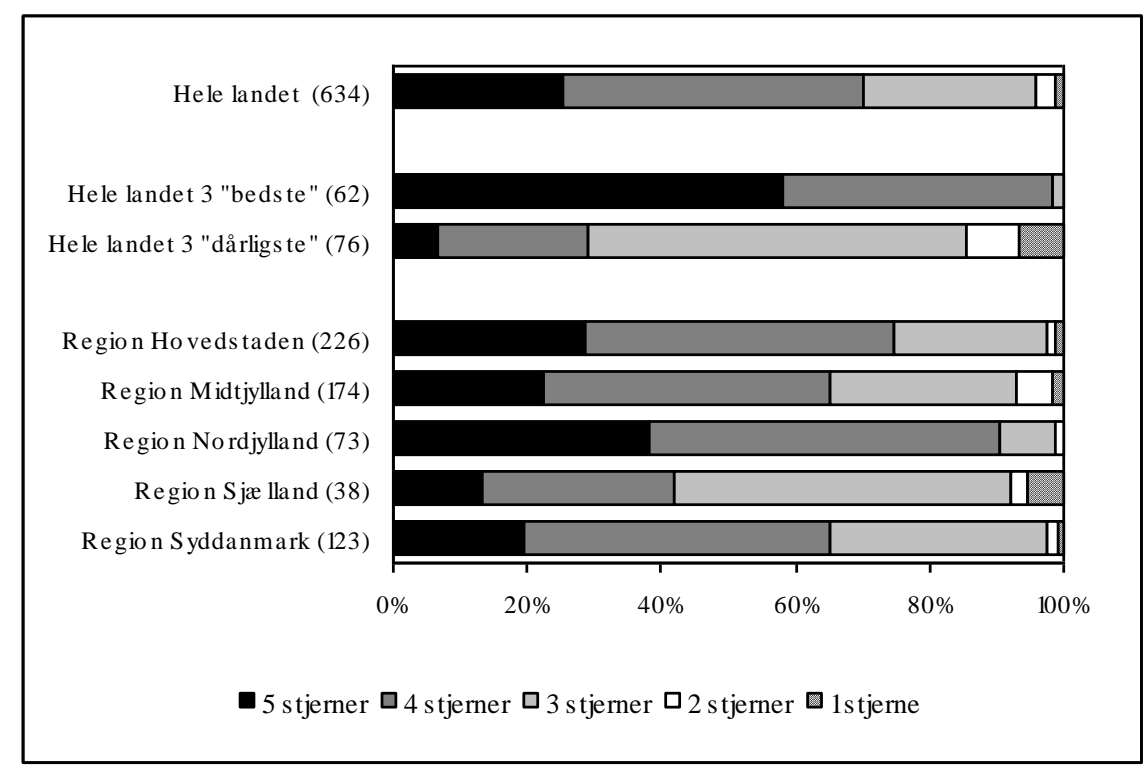

Figur 2.11: Samlede indtryk af indlæggelsen

Kilde. Patienterne og deres forældre har ordet. Unders $\varnothing$ gelse i de børne- og ungdomspsykiatriske dag- og døgnafsnit i Danmark 2007-08, Center for Kvalitetsudvikling, marts 2009.

Der var forholdsvis store variationer i tilfredsheden inden for de enkelte børne- og ungdomspsykiatriske afsnit.

Blandt besvarelserne fra afsnittene blev det analyseret, hvordan patientens køn, patientens alder, ventetid, indlæggelseslængde, anvendelse af tvang og forældrenes antal kontakter med afsnittet påvirkede svarpersonernes samlede vurdering af afsnittet. Baggrundsforholdene blev taget i betragtning samtidigt i én samlet analyse.

Det, der blandt disse forhold påvirkede besvarelserne, var patientens $\mathrm{k} ø$, hvor forældre til piger var signifikant mindre tilfredse end forældre til drenge.

Forældre til patienter på 15 år og derover var signifikant mindre tilfredse end forældre til patienter på 0-7 år.

Forældre til patienter der havde oplevet tvang var signifikant mindre tilfredse end forældre til patienter, der ikke havde oplevet tvang.

Forældre der havde haft mere end 4 kontakter var signifikant mere tilfredse end forældre der havde haft 1-4 kontakter med afsnittet.

Forældrene blev spurgt, hvordan indlæggelsen var i forhold til de forventninger de havde på forhånd. Figuren nedenfor viser dette. 


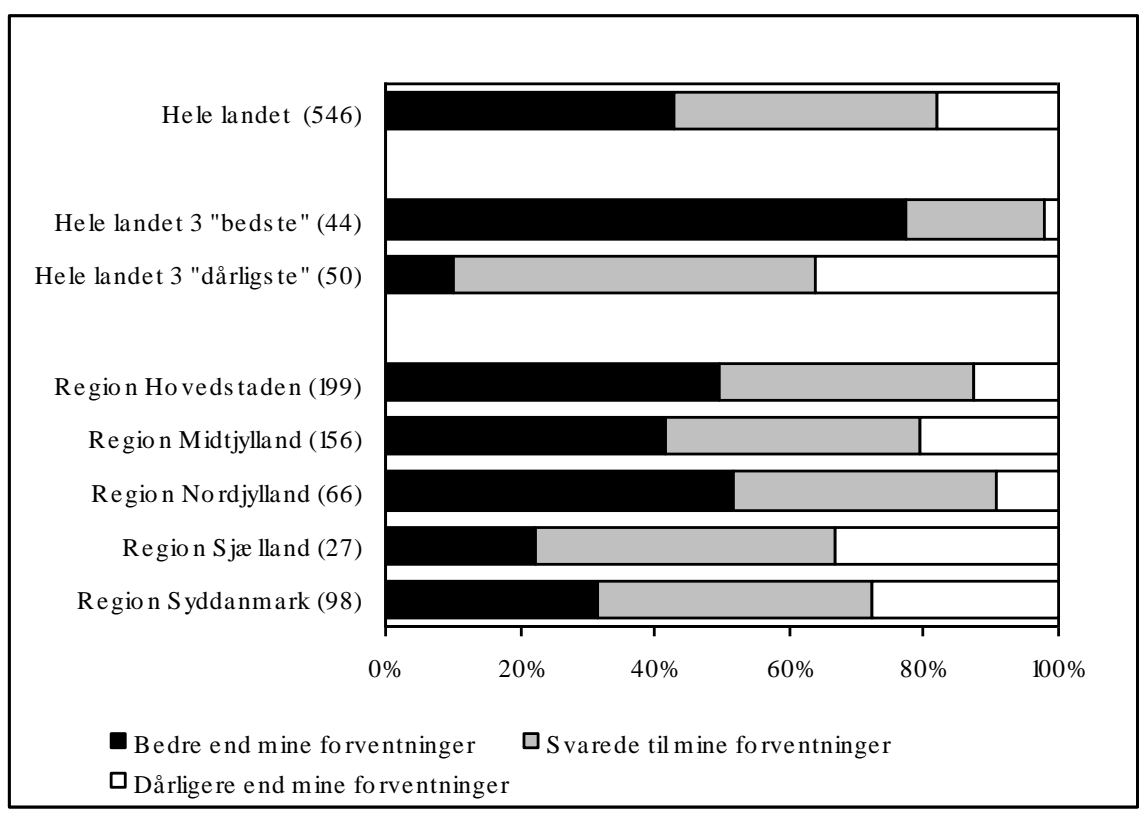

Figur 2.12: Indlæggelsen i forhold til forventninger

Kilde . Patienterne og deres forældre har ordet. Undersøgelse i de børne- og ungdomspsykiatriske dag- og døgnafsnit i Danmark 2007-08, Center for Kvalitetsudvikling, marts 2009.

I figuren nedenfor vises landsresultatet for de øvrige spørgsmål, der vedrører patientens kontakt med afsnittet. Spørgsmålene er sorteret efter tilfredshed. 


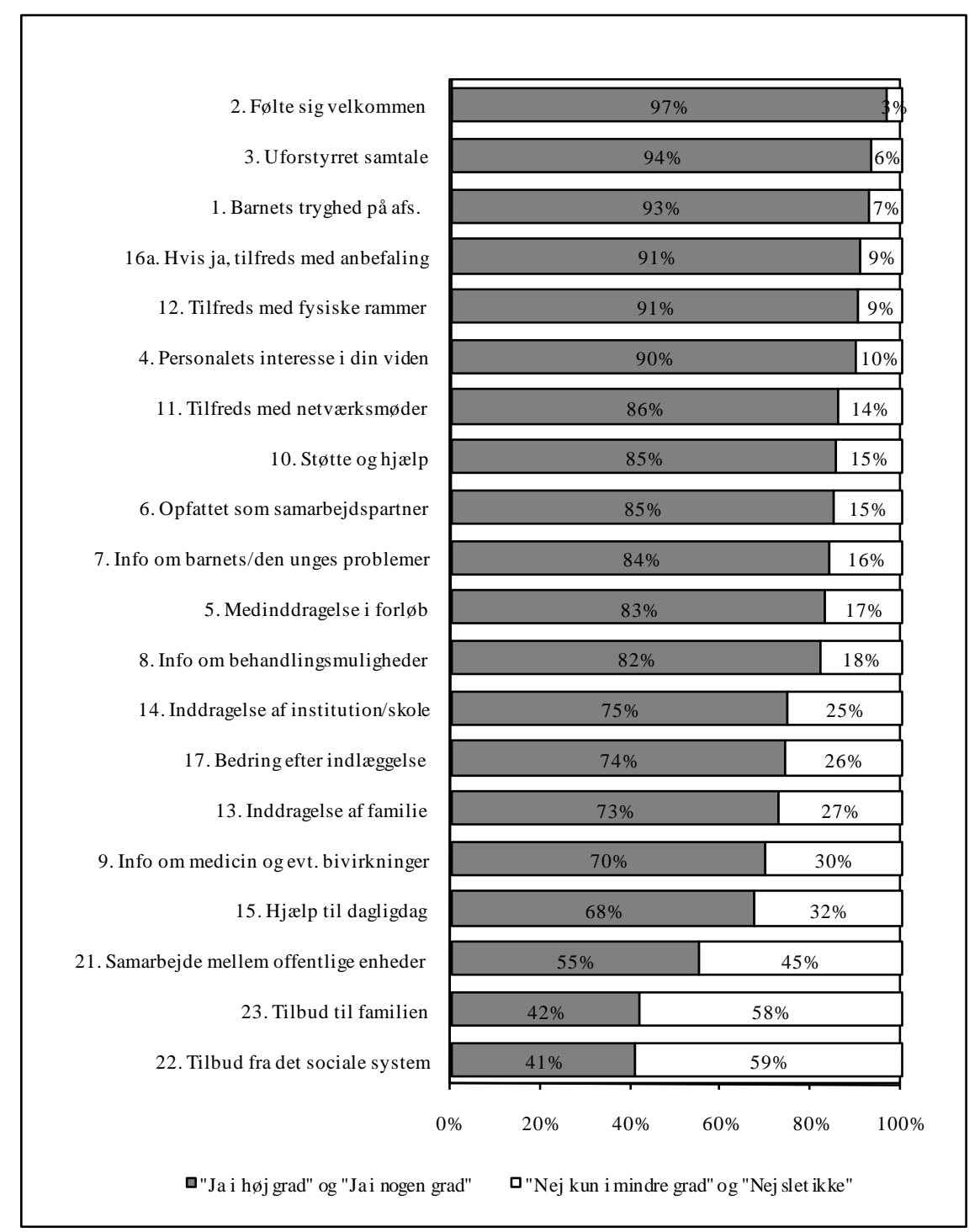

Figur 2.13: Øvrige spørgsmål om tilfredshed

Kilde. . Patienterne og deres forældre har ordet. Undersøgelse i de børne- og ungdomspsykiatriske dag- og døgnafsnit i Danmark 2007-08, Center for Kvalitetsudvikling, marts 2009.

\section{Voksenpsykiatri}

Fra 1. januar 2009 til 31. maj 2009 (retspsykiatrien 1. juni 2008 til 31. maj 2009) fik 7.897 patienter fra 194 psykiatriske sengeafsnit i Danmark udleveret et spørgeskema. 5.289 patienter besvarede skemaet. På landsplan er undersøgelsens svarprocent dermed på 67.

En bortfaldsanalyse blandt patienter viste, at svarpersonerne var repræsentative for de patienter, der fik tilbudt et spørgeskema.

Patienterne blev bedt om at give deres samlede indtryk af indlæggelsen gennem tildeling af 1-5 stjerner jævnfør Box 1. 


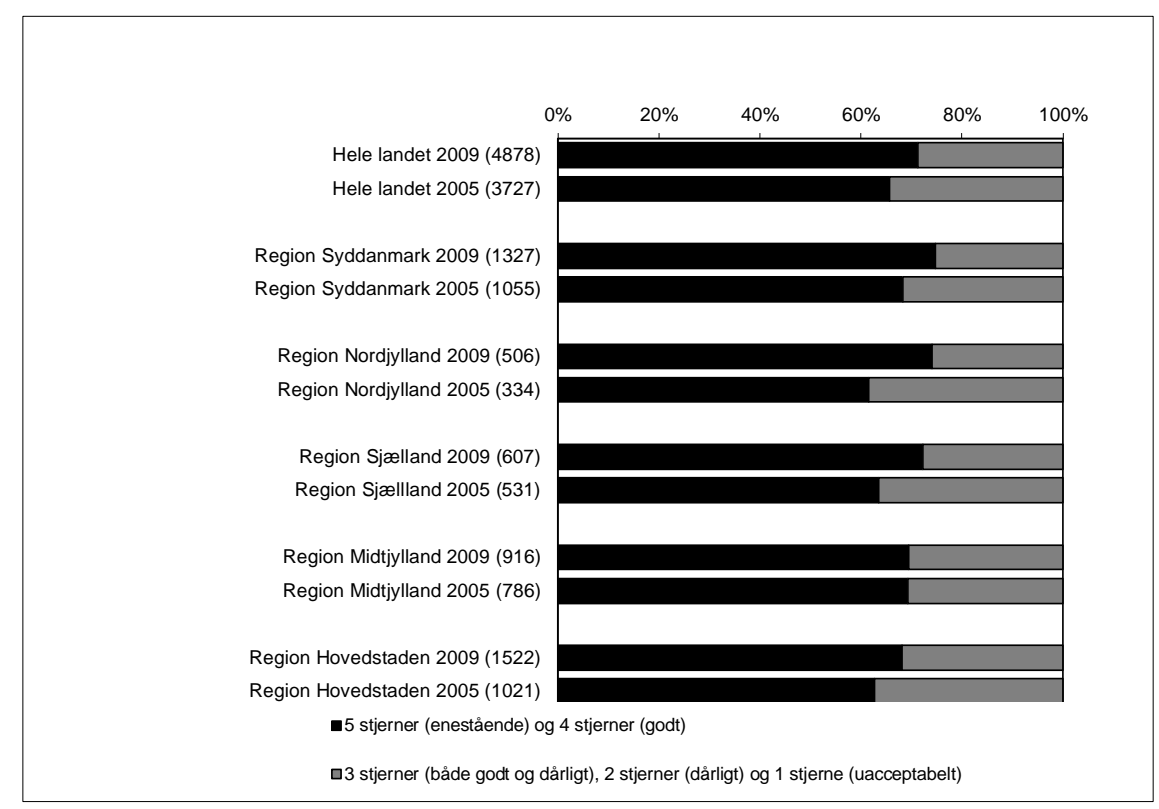

Figur 2.14: Samlede indtryk af indlæggelsen 2009 og 2005

Kilde. Patienterne og de pårørende har ordet. Undersøgelse på de psykiatriske sengeafsnit i Danmark 2009, Center for Kvalitetsudvikling, februar 2010.

Tabellen viser, at patienterne samlet set var blevet mere tilfredse med deres indlæggelse i 2009 i forhold til i 2005.

Blandt besvarelserne fra alle afsnit blev det analyseret, hvordan patienternes alder, køn, modersmål, diagnose, indlæggelseslængde og oplevelse af tvang og et eventuelt retsligt forhold påvirkede svarpersonernes samlede vurdering af afsnittet. Baggrundsforholdene blev taget i betragtning samtidig i én samlet analyse.

Det, der blandt disse forhold påvirkede besvarelserne, var hvorvidt patienterne havde været tvangsindlagt eller ej.

I Figur 2.15 vises landsresultatet for de øvrige spørgsmål, der vedrører patientens indlæggelse. Spørgsmålene er sorteret efter tilfredshed. 


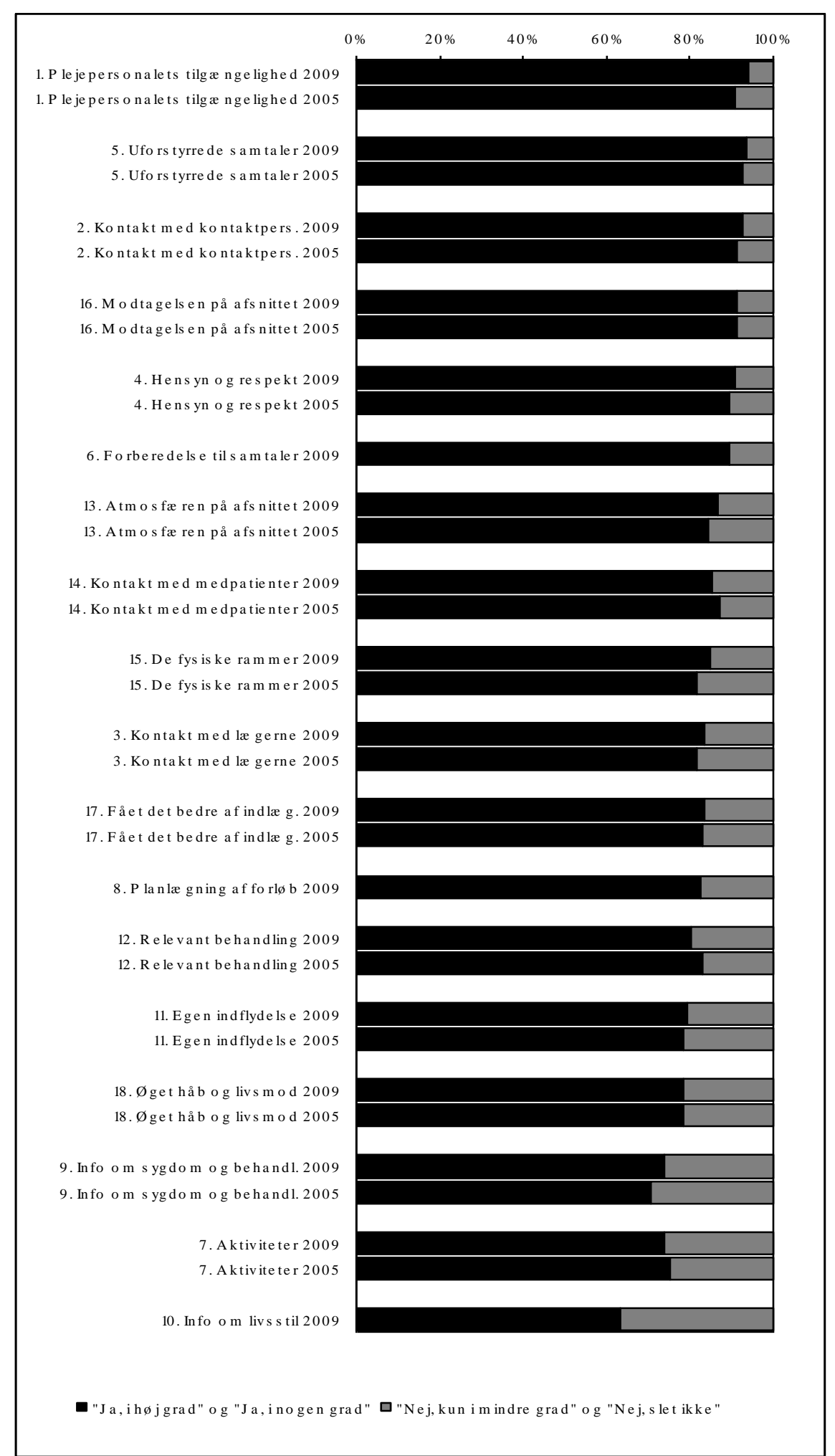

Figur 2.15: Tilfredshed vedr. patientens indlæggelse

Kilde. Patienterne og de pårørende har ordet. Unders $\varnothing$ gelse på de psykiatriske sengeafsnit i Danmark 2009, Center for Kvalitetsudvikling, februar 2010. 
Patienterne blev spurgt om syv faktuelle spørgsmål vedrørende, hvorvidt de havde fået skriftlig information om deres sygdom og behandling, om de oplevede fejl under deres indlæggelse, hvorvidt personalet havde kontakt med deres pårørende, om der var lavet aftaler om tiden efter deres udskrivelse, om der var samarbejde mellem de forskellige steder, som patienten havde kontakt med vedrørende sygdommen, om patienten havde fået tilbud om psykoedukation og endelig, om patienten savnede andre behandlingstilbud i psykiatrien.

Til flere af disse spørgsmål knyttede der sig et tillægsspørgsmål, der fokuserede på, hvorvidt patienten var tilfreds med det pågældende. Spørgsmålene fremstilles samlet i Figur 2.16, hvor tilfredshedsspørgsmålene er dikotomiseret, således at de to positive svarkategorier og de to negative svarkategorier er lagt sammen. 


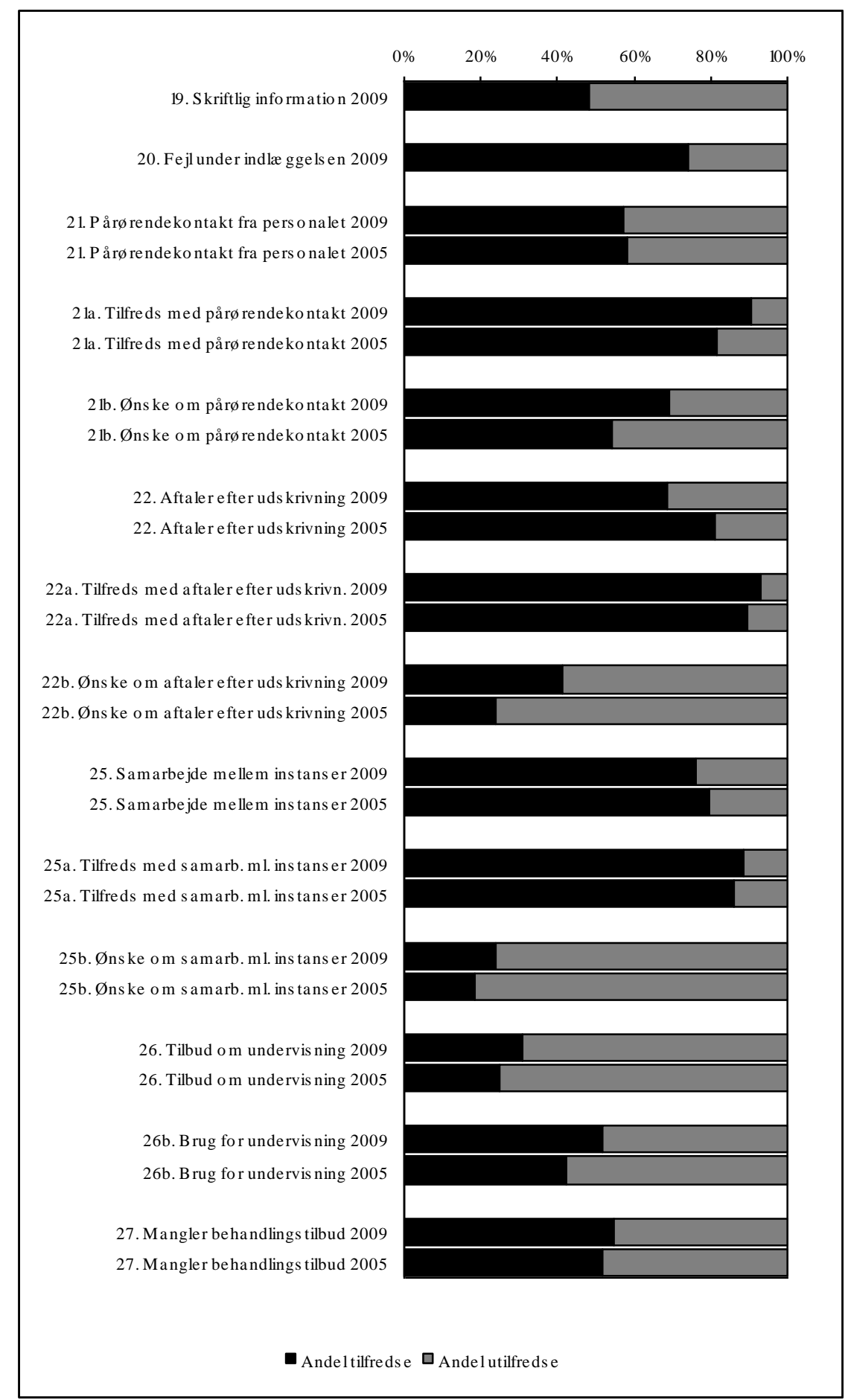

Figur 2.16: Faktuelle spørgsmål med tilhørende tilfredshedsspørgsmål

Kilde. Patienterne og de pårørende har ordet. Undersøgelse på de psykiatriske sengeafsnit i Danmark 2009, Center for Kvalitetsudvikling, februar 2010.

Af de patienter, der oplevede fejl, mener $54 \%$, at personalet klarede fejlen virkelig godt eller godt, $33 \%$ mener, at personalet klarede fejlen dårligt eller virkelig dårligt, og endelig siger $13 \%$, at personalet ikke har erkendt eller opdaget fejlen. 


\section{Pårørendeundersøgelsen (voksenpsykiatri)}

Fra 1. januar 2009 til 31. maj 2009 fik 2696 pårørende fra 174 psykiatriske sengeafsnit i Danmark udleveret et spørgeskema. 1.250 pårørende besvarede skemaet. På landsplan er undersøgelsens svarprocent dermed på 46.

En bortfaldsanalyse blandt de pårørende viste, at svarpersonerne var repræsentative for de pårørende, der fik tilbudt et spørgeskema.

De pårørende blev bedt om at give deres samlede indtryk af sengeafsnittets kontakt til dem gennem tildeling af 1-5 stjerner jævnfør Box 1.

Figuren nedenfor viser de pårørendes samlede vurdering i 2009 og 2005.

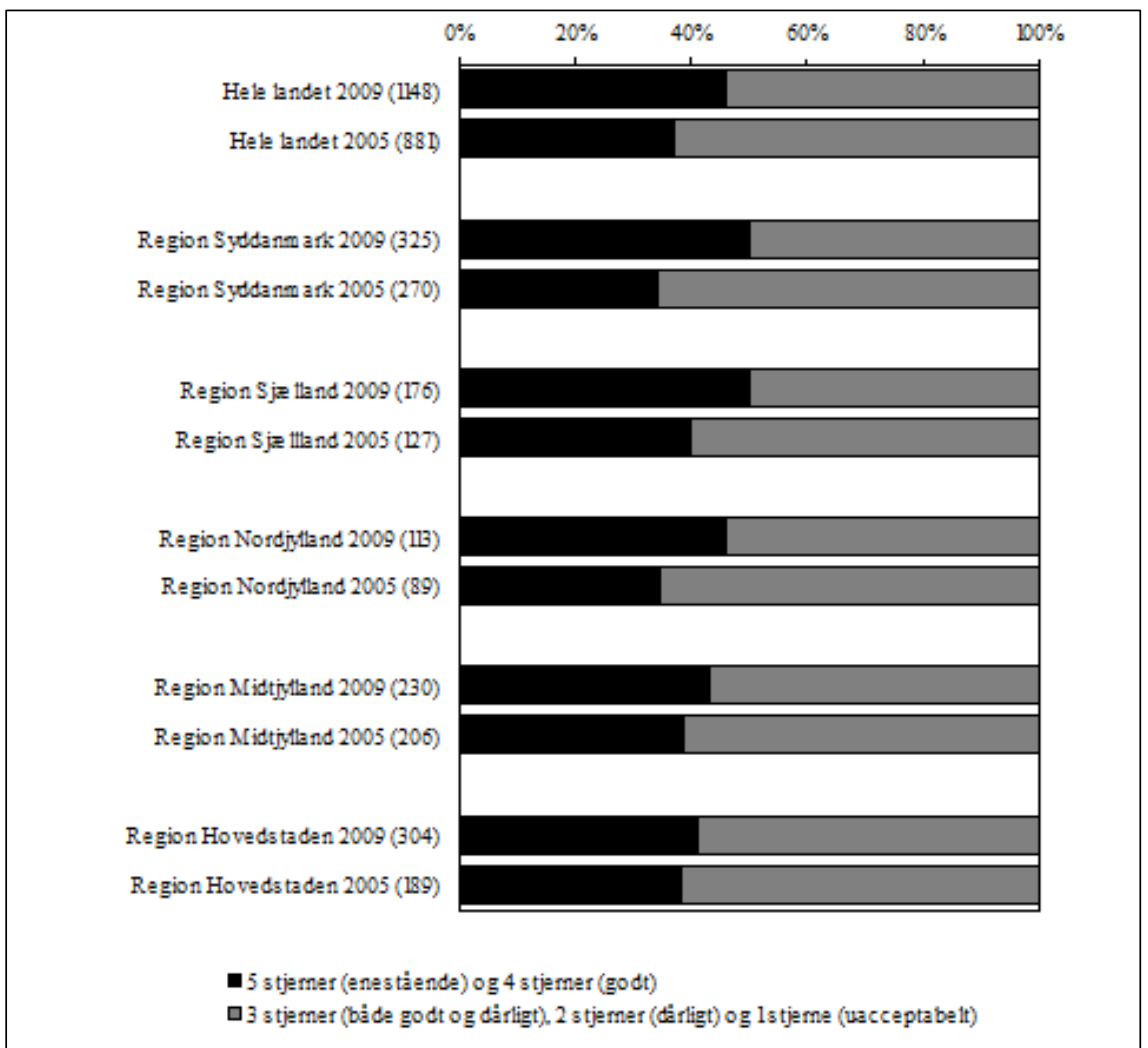

Figur 2.17: Hvad er dit samlede indtryk af sengeafsnittets kontakt med dig?

Kilde. Patienterne og de pårørende har ordet. Undersøgelse på de psykiatriske sengeafsnit i Danmark 2009, Center for Kvalitetsudvikling, februar 2010.

Figuren viser, at de pårørende samlet set er blevet mere tilfredse med sengeafsnittets kontakt til dem i 2009 i forhold til 2005.

I de tre afsnit i landet, hvor der var relativt flest tilfredse pårørende, giver $72 \%$ af de pårørende 5 eller 4 stjerner.

I de tre afsnit i landet, der har den laveste tilfredshed, giver $22 \%$ af de pårørende 5 eller 4 stjerner

Blandt besvarelserne fra alle afsnit er det analyseret, hvordan de pårørendes alder, køn, modersmål, relation til patienten, hvor belastet de følte sig af patientens sygdom, hvor længe de havde haft kontakt med det psykiatriske system og hvor mange samtaler de havde haft med personalet under denne indlæggelse, påvirkede deres samlede vurdering af afsnittet. 
Det, der blandt disse forhold påvirkede besvarelserne, var hvorvidt de pårørende havde haft samtaler med personalet på sengeafsnittet eller ej.

I Figur 2.18 nedenfor vises landsresultatet for de øvrige spørgsmål, der vedrører de pårørendes kontakt med sengeafsnittet og med psykiatrien som helhed. Spørgsmålene er sorteret efter tilfredshed.

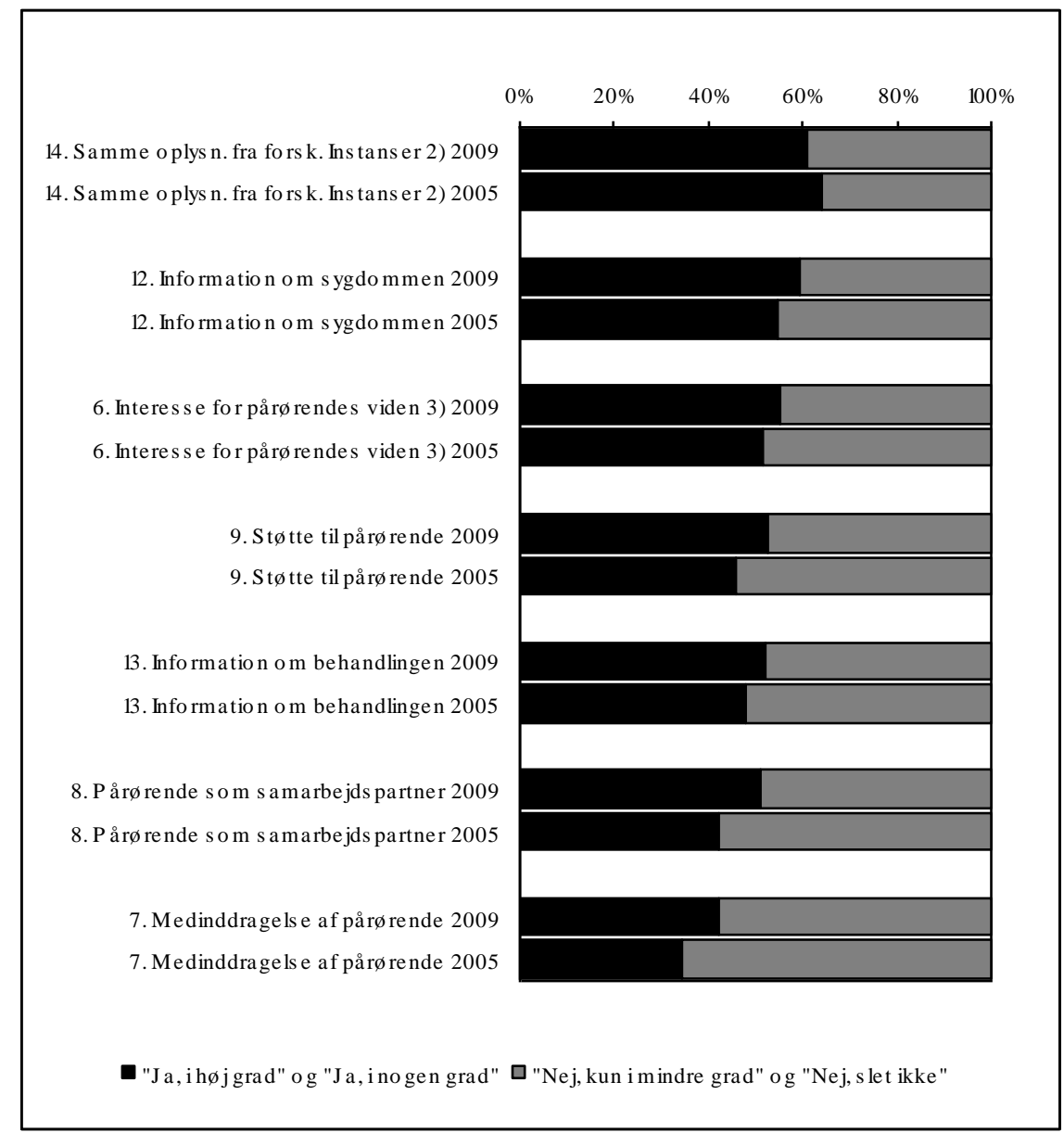

Figur 2.18: Spørgsmål vedr. kvaliteten af information og kontakt

Kilde. Patienterne og de pårørende har ordet. Unders $\emptyset$ gelse på de psykiatriske sengeafsnit i Danmark 2009, Center for Kvalitetsudvikling, februar 2010.

De pårørende blev spurgt om otte faktuelle spørgsmål, der vedrører deres mulighed for at tale uforstyrret med patienten på sengeafsnittet, deres kontakt til personalet, om de er blevet tilbudt undervisning om psykiske sygdomme og informeret om nogle pårørende rådgivninger og endelig, om de savnede tilbud til dem som pårørende i psykiatrien.

Til spørgsmålet om de pårørende er blevet tilbudt undervisning om psykiske sygdomme, knytter der sig et tillægsspørgsmål. Dette fokuserer på, hvorvidt de pårørende havde brug for undervisning, hvis ikke de modtog undervisning. Spørgsmålet fremstilles også i Figur 2.19 blot i dikotomiseret form, således at de to positive svarkategorier og de to negative svarkategorier er lagt sammen. 


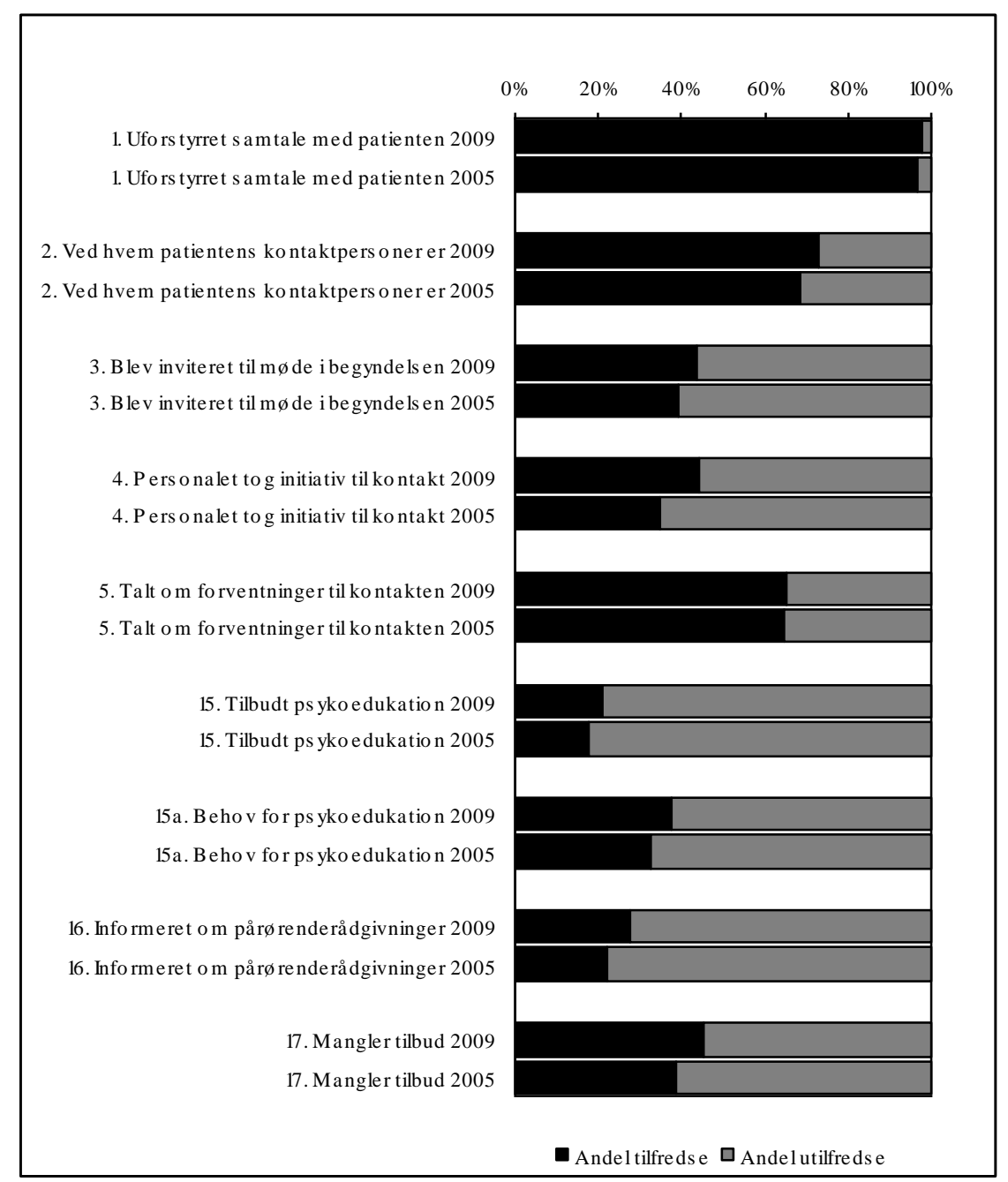

\section{Figur 2.19: 8 Faktuelle spørgsmål}

Kilde. Patienterne og de pårørende har ordet. Undersøgelse på de psykiatriske sengeafsnit i Danmark 2009, Center for Kvalitetsudvikling, februar 2010.11.1.5 Distriktspsykiatri

\section{Distriktpsykiatri}

107 af de 132 distriktspsykiatriske enheder, der deltog i patientundersøgelsen, havde overvejende almenpsykiatriske patienter.

12 af de 25 specialenheder havde samme målgruppe, nemlig gerontopsykiatriske patienter. I forlængelse af resultaterne fra almenpsykiatrien vil hovedresultater fra gerontoenhederne kortfattet blive beskrevet. Undersøgelsesresultater fra de resterende specialenheder er ikke medtaget i dette afsnit.

Da der var væsentlige forskelle mellem specialenhederne og de almenpsykiatriske enheder, særligt hvad angår patientgrupperne, fremstilles resultaterne separat.

Fra den 1. oktober til den 30. november 2007 fik 16.143 patienter fra de 132 distriktspsykiatriske enheder i Danmark udleveret et spørgeskema. 10.527 patienter besvarede skemaet. På landsplan er unders $\emptyset$ gelsens svarprocent dermed på 65. Det er tilfredsstillende for en under- 
søgelse af denne karakter. Svarprocenten fordeler sig således på de almenpsykiatriske distriktsenheder og specialenhederne:

\begin{tabular}{lrrr} 
Tabel 2.11.1: Antal udleverede og besvarede spørgeskemaer & \\
\hline Distriktspsykiatrisk & $\begin{array}{r}\text { Antal } \\
\text { område (antal enheder) }\end{array}$ & $\begin{array}{r}\text { Antal } \\
\text { udleverede spørgeske- } \\
\text { maer }\end{array}$ & $\begin{array}{r}\text { Svar-procent } \\
\text { besvarede spørge- } \\
\text { skemaer }\end{array}$ \\
\hline Almenpsykiatri (107) & 14.282 & 9.466 & $66 \%$ \\
Gerontoenheder (12) & 1.026 & 511 & $50 \%$ \\
$\varnothing$ vrige specialenheder (13) & 835 & 550 & $66 \%$ \\
Alle (132) & 16.143 & 10.527 & $65 \%$ \\
\hline
\end{tabular}

Kilde. Patienterne og de pårørende har ordet. Unders $\varnothing$ gelse i distriktspsykiatrien i Danmark 2007-08,Center for Kvalitetsudvikling, september 2008

En bortfaldsanalyse blandt patienter fra de almenpsykiatriske enheder viste, at svarpersonerne er repræsentative for alle almenpsykiatriske patienter, der fik et spørgeskema, hvad angår køn, alder, modersmål, varighed af kontakt med distriktspsykiatrien og diagnose.

Diagnose er dog ikke angivet på $9 \%$ af de besvarede spørgeskemaer.

Patienterne blev bedt om at give deres samlede indtryk af distriktspsykiatrien gennem tildeling af 1-5 stjerner. Patienternes skriftlige begrundelser for deres stjernetildeling viste følgende: 4 og 5 stjerner udtrykker høj grad af tilfredshed, 3 stjerner er typisk udtryk for klar utilfredshed på nogle områder, 2 stjerner eller 1 stjerne er udtryk for en generel og markant utilfredshed. Disse tre inddelinger repræsenterer hver deres kategori i figuren nedenfor.

Tal i parentes viser antal patientbesvarelser på spørgsmålet. 


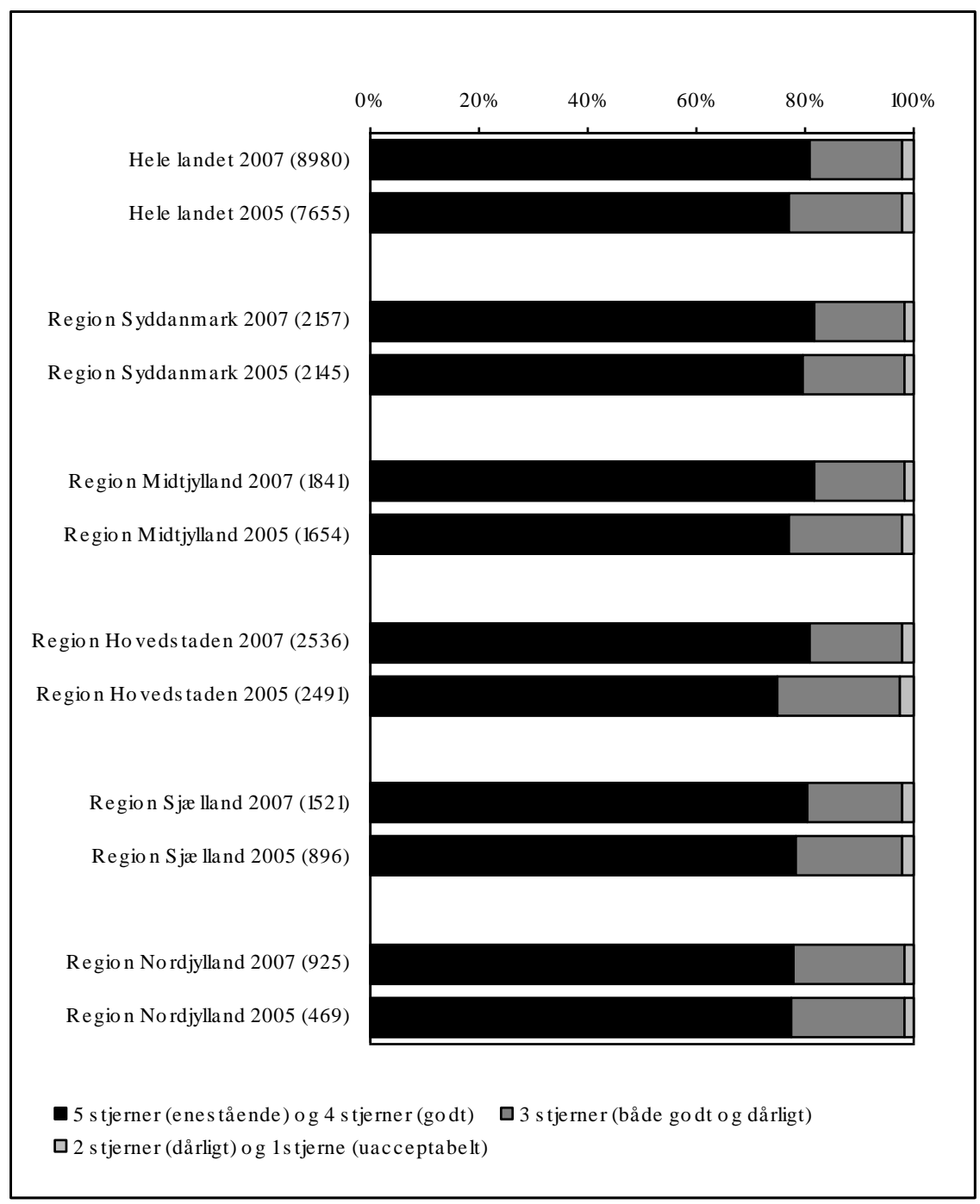

Figur 2.20: Hvad er dit samlede indtryk af distriktpsykiatrien. Almenpsykiatrien: Landsresultat og regionale resultater 2005 og 2007

Kilde. Patienterne og de pårørende har ordet. Undersøgelse i distriktspsykiatrien i Danmark 2007-08,Center for Kvalitetsudvikling, september 2008

Der var forholdsvis store variationer i patienttilfredsheden inden for de enkelte distriktspsykiatriske enheder.

Blandt besvarelserne fra almenpsykiatrien blev det analyseret, hvordan patienternes alder, køn, modersmål, diagnose og varighed af kontakt med distriktspsykiatrien påvirkede svarpersonernes samlede vurdering af distriktspsykiatrien. Baggrundsforholdene blev taget i betragtning samtidigt i én samlet analyse.

Det, der blandt disse forhold påvirkede besvarelserne, var patienternes alder, hvor gruppen af 18-39-årige er signifikant mindre tilfredse end gruppen over 40 år.

Patienter, der ikke havde dansk som modersmål, var signifikant mere tilfredse end patienter, der havde dansk som modersmål. 
Patienter med diagnosen F3 (affektive sindslidelser) var signifikant mere tilfredse end patienter med diagnosen F2 (skizofreni o.l.), mens personer med diagnosen F6 (forandringer i personlighedsstruktur m.m.) var signifikant mindre tilfredse end patienter med diagnosen F2 (skizofreni o.l.).

Patienter fra Region Nordjylland var signifikant mindre tilfredse end patienter fra Region Syddanmark.

Det viste sig, at det var de samme forhold der gjorde sig gældende som i undersøgelsen fra 2005, bortset fra at personer med diagnosen F6 ikke adskilte sig signifikant fra personer med diagnosen F2 i 2005.

Patienterne blev bedt om med egne ord at begrunde deres tildeling af antal stjerner. Det svarede $62 \%$ af svarpersonerne fra de almenpsykiatriske enheder på - og $44 \%$ af patienterne fra de gerontopsykiatriske distriktsenheder.

Patienterne blev også bedt om at beskrive, hvad der havde størst betydning for dem i kontakten med distriktspsykiatrien. Det havde $77 \%$ af svarpersonerne fra de almenpsykiatriske enheder gjort - og $60 \%$ af patienterne fra gerontopsykiatrien.

I Figur 2.21 vises landsresultatet for de øvrige spørgsmål, der vedrører patientens kontakt med distriktspsykiatrien. 


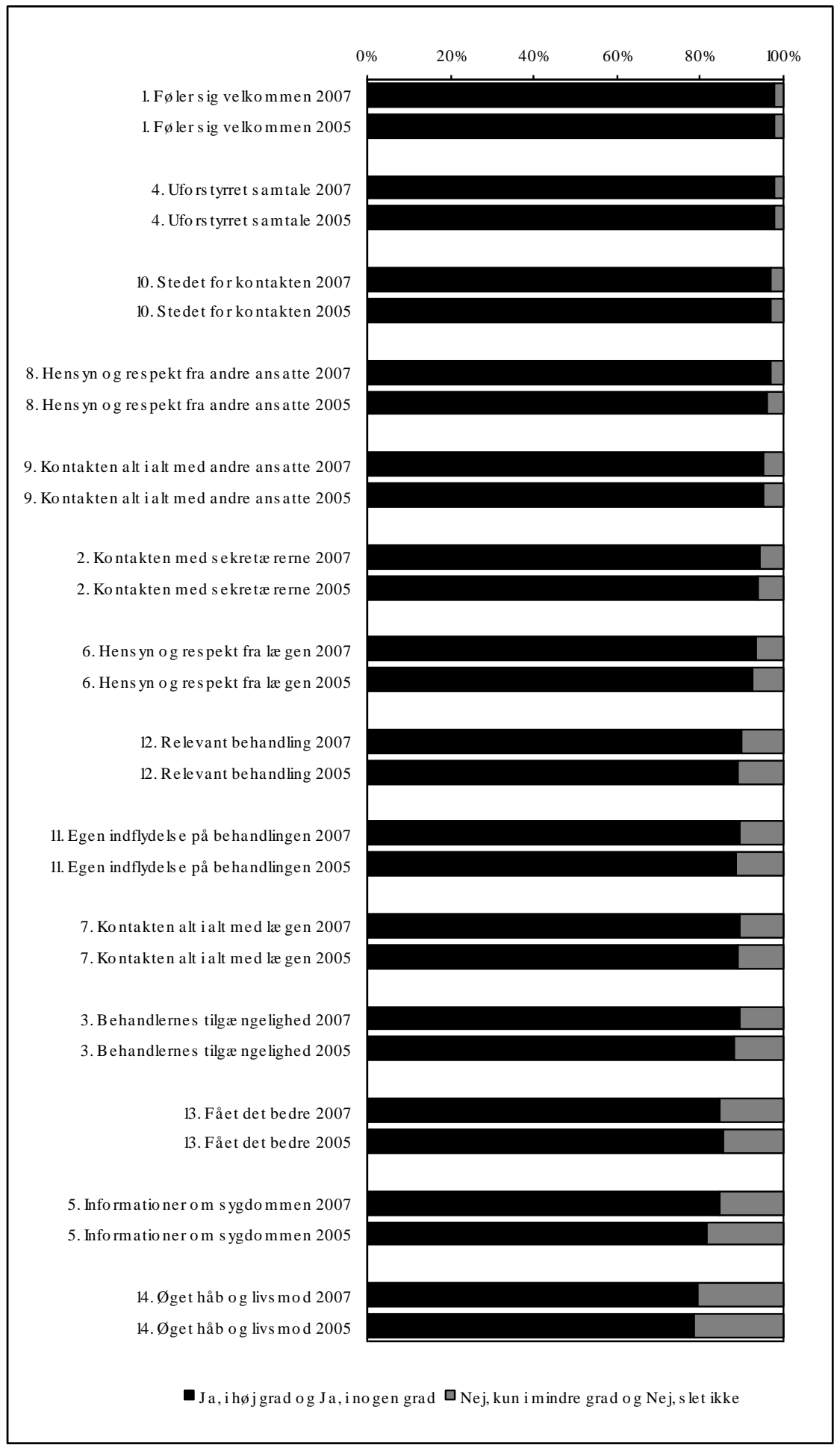

Figur 2.21: 14 tilfredshedsspørgsmål vedrørende patientens kontakt med distriktpsykiatrien, Almenpsykiatrien, landsresultater 2005 og 2007

Kilde. Patienterne og de pårørende har ordet. Undersøgelse i distriktspsykiatrien i Danmark 2007-08,Center for Kvalitetsudvikling, september 2008 
$36 \%$ af patienterne i de almenpsykiatriske distriktsenheder oplyste, at distriktspsykiatrien havde kontakt med deres pårørende. $94 \%$ af disse patienter var tilfredse i høj grad eller i nogen grad med den kontakt, der var. $58 \%$ af patienterne oplyste, at distriktspsykiatrien ikke havde kontakt med de pårørende. $37 \%$ af disse patienter ville gerne have, at der skulle være kontakt. $6 \%$ af patienterne vidste ikke/svarede ikke på, om distriktspsykiatrien havde kontakt med deres pårørende.

$76 \%$ af patienterne fra de gerontopsykiatriske distriktsenheder oplyste, at dervarr kontakt mellem deres pårørende og behandlerne. $97 \%$ af disse patienter var tilfredse i høj grad eller i nogen grad med kontakten. $21 \%$ af patienterne oplyste, at behandlerne ikke havde pårørendekontakt. Af disse ville $43 \%$ gerne have, at der skulle være kontakt

$62 \%$ af patienterne i de almenpsykiatriske enheder oplyste, at der var samarbejde med andre steder end distriktspsykiatrien om deres sygdom. Det kunne bl.a. være praktiserende læge, psykiatrisk sengeafsnit, bostøtte, bosted, dagtilbud, privatpraktiserende psykiater/psykolog og kommunens sagsbehandler.

Af disse patienter var $91 \%$ i høj grad eller i nogen grad tilfredse med samarbejdet. $17 \%$ af patienterne oplyste, at der ikke var noget samarbejde, og heraf ville $72 \%$ gerne have, at der skulle samarbejdes. $22 \%$ af patienterne vidste ikke, om der var et samarbejde.

Af patienterne fra de gerontopsykiatriske enheder, der oplyste, at der var samarbejde mellem forskellige steder om deres sygdom, var $97 \%$ i høj grad eller i nogen grad tilfredse med samarbejdet. Af de patienter, der oplyste, at der ikke var noget samarbejde, ville $74 \%$ gerne have, at der skulle være det.

Patienterne blev spurgt, om psykiatrien har tilbudt dem undervisning om deres sygdom og behandling. $38 \%$ af patienterne i de almenpsykiatriske enheder svarede bekræftende.

Der skal gøres opmærksom på, at psykoedukation/undervisning nogle steder gives som en del af behandlingen, og at nogle patienter derfor kan have svært ved at svare på, om de er blevet tilbudt undervisning.

De $55 \%$ af patienterne, der ikke mente, at de havde modtaget undervisning, blev spurgt, om de har haft brug for det. Det svarede $48 \%$ bekræftende på.

I de gerontopsykiatriske distriktsenheder udtrykte $27 \%$ af de patienter, der ikke blev tilbudt undervisning, at de havde behov for dette.

Patienterne blev spurgt, om de savnede behandlingstilbud i psykiatrien, f.eks. samtaleterapi, psykologhjælp, fysioterapi, ergoterapi, bevægelse, forskellige aktivitetstilbud eller noget andet. $30 \%$ af patienterne i de almenpsykiatriske distriktsenheder svarede, at de savnede behandlingstilbud i psykiatrien.

I de gerontopsykiatriske distriktsenheder savnede $13 \%$ af patienterne behandlingstilbud. 


\section{Pårørendeundersøgelsen (Distriktspsykiatri)}

107 af de 133 distriktspsykiatriske enheder, der deltog i pårørendeundersøgelsen, havde overvejende almenpsykiatriske patienter. Svarene fra pårørende til patienter tilknyttet disse enheder fremstilles i dette afsnit.

13 af de 26 specialenheder havde samme målgruppe, nemlig gerontopsykiatriske patienter. I forlængelse af resultaterne fra almenpsykiatrien vil hovedresultater fra gerontoenhederne kortfattet blive beskrevet. Undersøgelsesresultater fra de resterende specialenheder er ikke medtaget i dette afsnit.

Da der var væsentlige forskelle mellem specialenhederne og de almenpsykiatriske enheder, særligt hvad angår patientgrupperne, fremstilles resultaterne separat. Endvidere var der regioner, der havde valgt ikke at have specialenheder med i undersøgelsen.

8.909 pårørende til patienter fra de 133 distriktspsykiatriske enheder i Danmark fik tilsendt et spørgeskema. 4.381 pårørende besvarede skemaet. På landsplan er undersøgelsens svarprocent dermed på 49. Det er lige under den acceptable grænse på 50 procent for en undersøgelse af denne karakter.

En bortfaldsanalyse blandt pårørende til patienter fra de almenpsykiatriske enheder viste, at svarpersonerne var repræsentative for hele gruppen af pårørende, der fik tilsendt et spørgeskema, hvad angår modersmål og den pårørendes forbindelse til patienten.

De pårørende blev bedt om at give deres samlede indtryk af distriktspsykiatrien gennem tildeling af 1-5 stjerner. De pårørendes skriftlige begrundelser for deres stjernetildeling (Box 1) viste følgende:

- 4 og 5 stjerner udtrykker høj grad af tilfredshed

- 3 stjerner er typisk udtryk for klar utilfredshed på nogle områder

- 2 stjerner eller 1 stjerne er udtryk for en generel og markant utilfredshed

Disse tre inddelinger repræsenterer hver deres kategori i figuren nedenfor.

Tal i parentes viser antal patientbesvarelser på spørgsmålet. 


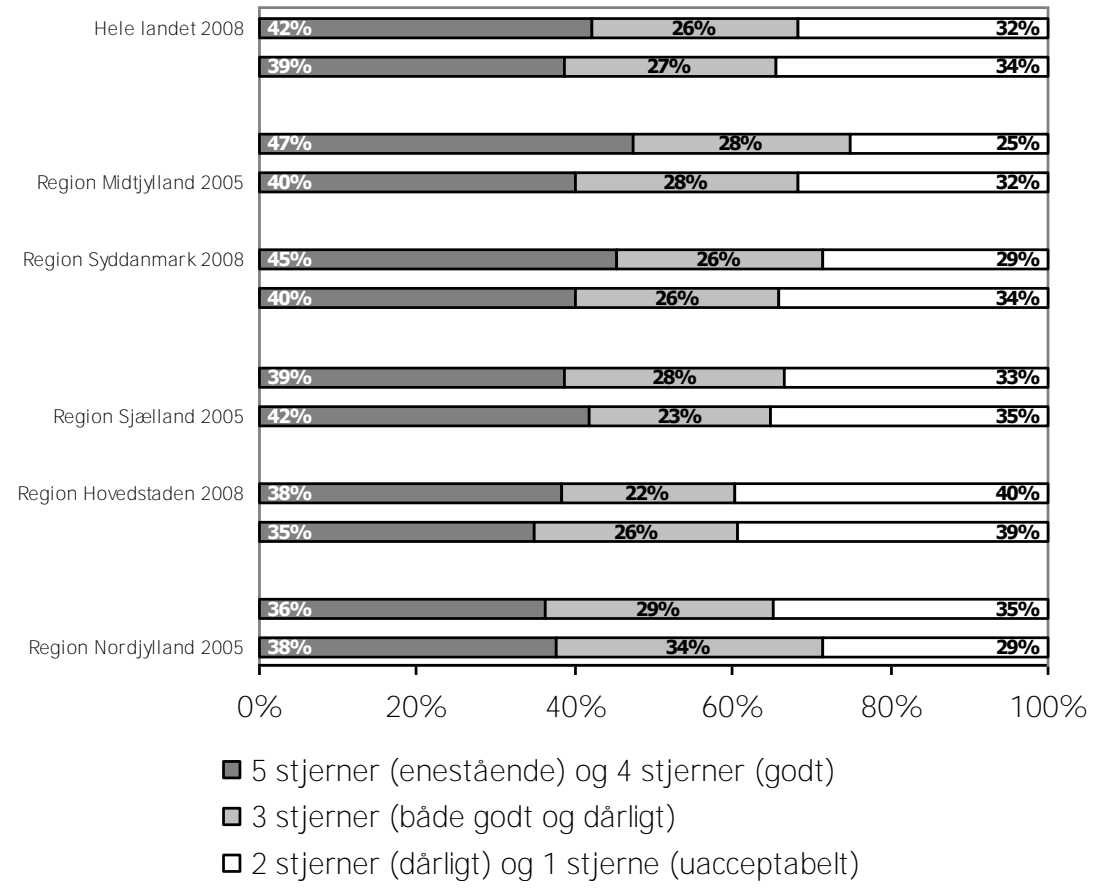

Figur 2.22: Hvad er dit samlede indtryk af distrikspsykiatriens kontakt med dig? Almenpsykiatrien. Landsresultater og regionale resultater 2005 og 2007

Kilde. Patienterne og de pårørende har ordet. Unders $\varnothing$ gelse i distriktspsykiatrien i Danmark 2007-08,Center for Kvalitetsudvikling, september 2008

Der var forholdsvis store variationer i pårørendetilfredsheden inden for de enkelte distriktspsykiatriske enheder.

Blandt besvarelserne fra pårørende til patienter i almenpsykiatrien blev det analyseret, hvordan de pårørendes baggrundsforhold påvirkede deres samlede vurdering af deres kontakt med distriktspsykiatrien. Baggrunds-forholdene blev taget i betragtning samtidigt i én samlet analyse.

Det viste sig, at det var de samme forhold der gjorde sig gældende som i undersøgelsen fra 2005.

Det, der i særlig grad påvirkede besvarelserne, var antallet af de pårørendes samtaler med personalet. Der var en markant tendens til, at pårørende, der ikke havde haft samtaler med personalet i distriktspsykiatrien, gavr færre stjerner end pårørende, der havde haft samtaler

Pårørende, der ikke havde dansk som modersmål, svarede signifikant mere positivt end pårørende, der havde dansk som modersmål. Ligeledes gav mænd, pårørende over 40 år og pårørende, der ikke følte sig ret belastet af patientens sygdom signifikant flere stjerner end henholdsvis kvinder, yngre pårørende og pårørende, der følte sig en del eller meget belastet af patientens sygdom. 
I Figur 2.23 vises landsresultatet for de seks faktuelle spørgsmål, som den pårørende kunne besvare med „Ja“, „Nej“ eller „Ved ikke/ej relevant". Resultaterne fremstilles kun for de almenpsykiatriske enheder.

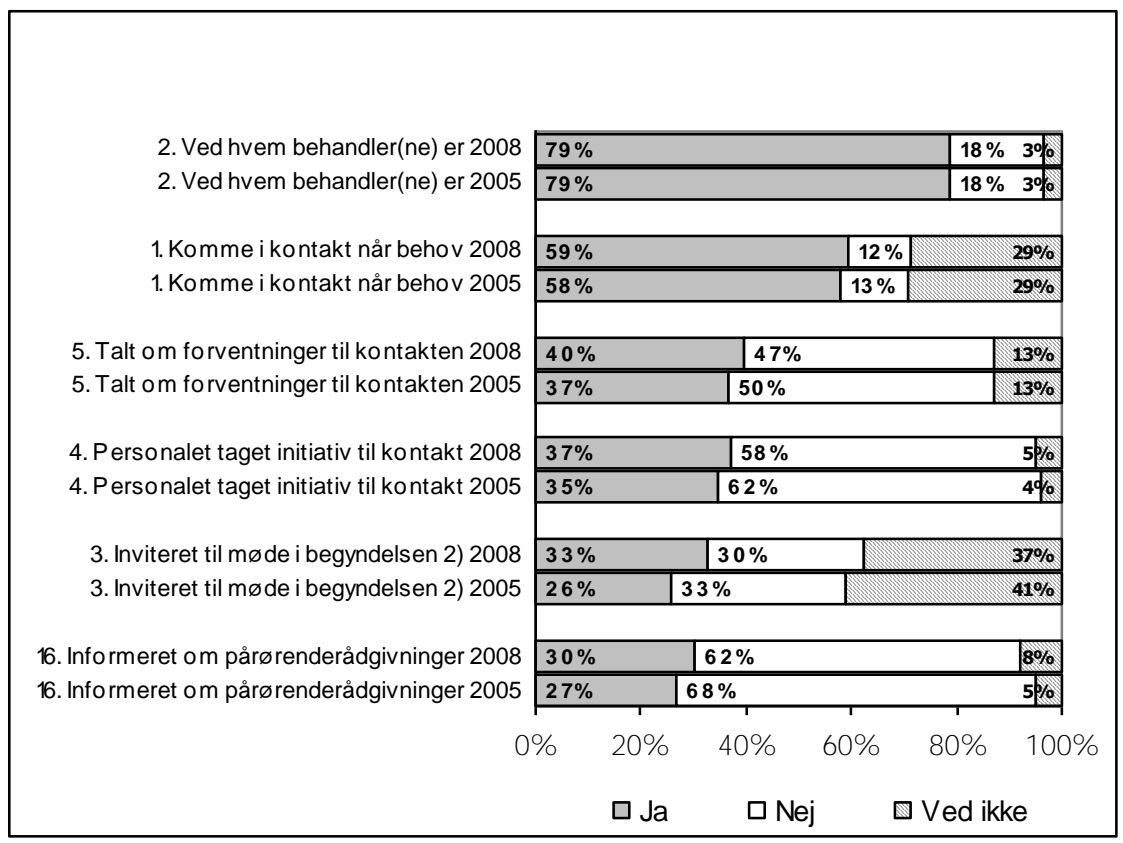

Figur 2.23: Seks faktuelle spørgsmål 1) Almenpsykiatrien

1) Spm. 16 stilles i forhold til psykiatrien som helhed, mens de øvrige fem spørgsmål specifikt vedrører distriktspsykiatrien.

2) Pårørende til patienter, der har været i kontakt med distriktspsykiatrien i mere end to år, bliver opfordret til at svare „Ved ikke/ej relevant".

Kilde. Patienterne og de pårørende har ordet. Undersøgelse i distriktspsykiatrien i Danmark 2007-08,Center for Kvalitetsudvikling, september 2008

Fra de gerontopsykiatriske distriktsenheder var der flest pårørende, der svarede „Ja“ på spørgsmålet om de vidste, hvem der var patientens behandler(e) i distriktspsykiatrien (89 \%) og færrest, der svarede "Ja“, hvad angår spørgsmålet om de var blevet informeret om nogen pårørenderådgivninger (28 \%).

I Figur 2.24 vises almenpsykiatriens landsresultat for de syv holdningsspørgsmål, der vedrører den pårørendes vurdering af information, kontakt og samarbejde. 


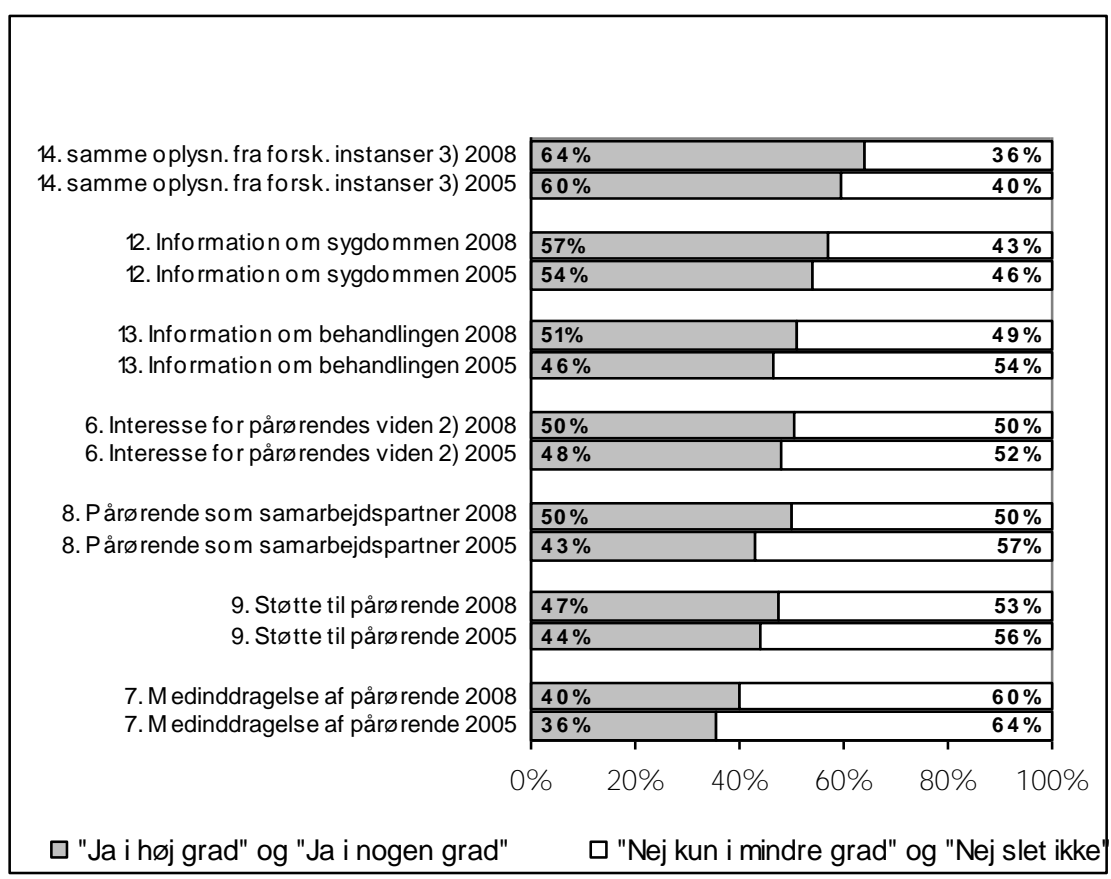

Figur 2.24: Syv spørgsmål vedr. kvaliteten af information og kontakt. Almen psykiatrien: Landsresultater 2005 og 2008

1. Spørgsmål 6-9 drejer sig om distriktspsykiatrien, mens spørgsmål 12-14 vedrører psykiatrien som helhed.

2. Pårørende, der ikke mener, at de har nogen erfaring eller viden, som personalet bør kende, bliver opfordret til at svare "Ved ikke/ej relevant".

3. Pårørende, der kun har haft kontakt med et enkelt sted, bliver opfordret til at svare „Ved ikke/ej relevant".

Kilde. Patienterne og de pårørende har ordet. Undersøgelse i distriktspsykiatrien i Danmark 2007-08, Center for Kvalitetsudvikling, september 2008

Fra de gerontopsykiatriske distriktsenheder var procentdelen af tilfredse pårørende højest, hvad angik spørgsmålet om interesse for de pårørendes viden (84 \% tilfredse) og lavest, hvad angik spørgsmålet om der havde været overensstemmelse mellem de oplysninger, de havde fået af behandlere forskellige steder i psykiatrien (73\% tilfredse).

I Figur 2.25 fremstilles svarene på de to holdningsspørgsmål, der vedrørte den pårørendes oplevelse af behandlingen af patienten i almenpsykiatrien som helhed. 


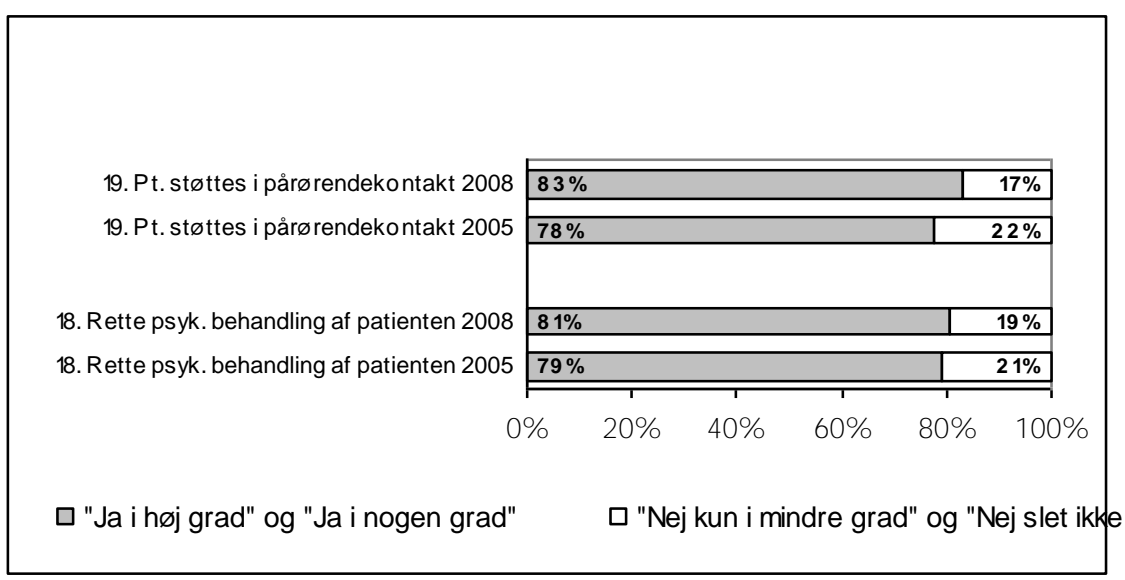

Figur 2.25: To spørgsmål vedr. psykiatriens behandling af patienten. Almenpsykiatrien: Landsresultater 2005 og 2008

Kilde. Patienterne og de pårørende har ordet. Undersøgelse i distriktspsykiatrien i Danmark 2007-08, Center for Kvalitetsudvikling, september 2008

Fra de gerontopsykiatriske distriktsenheder var $90 \%$ af de pårørende i høj grad eller i nogen grad tilfredse i forhold til spørgsmål 18 og 88 \% i forhold til spørgsmål $19.35 \%$ af samtlige svarpersoner har uddybet deres svar kvalitativt.

De pårørende blev spurgt, om psykiatrien havde tilbudt dem undervisning om psykiske sygdomme og behandling. $26 \%$ af de pårørende fra almenpsykiatrien svarede bekræftende, 5 \% svarede „Ved ikke“, og $69 \%$ svarede benægtende. Sidstnævnte gruppe blev spurgt, om de havde haft brug for undervisning. Det svarede $64 \%$ bekræftende på. I gerontopsykiatrien svarede $77 \%$ benægtende på, om psykiatrien havde tilbudt undervisning, og heraf svarede $41 \%$ af de pårørende bekræftende på, om de havde haft brug for undervisning.

$43 \%$ af de pårørende i almenpsykiatrien og $23 \%$ i gerontopsykiatrien tilkendegav, at de savnede tilbud i psykiatrien til dem som pårørende. $36 \%$ af de, der savnede tilbud, uddybede deres svar kvalitativt.

\subsubsection{Finland}

THL (tidigare Stakes) undersöker vart annat år i sin 'Finländarnas välfärd och tjänster' - undersökning befolkningens åsikter om social- och hälsovården i Finland. I allmänhet har svararna varit nöjda med hälsovårdens tjänster. En av fem svarare önskade dock en större reform i hälsovården. Hälsovårdssystemet kunde förbättras genom att få tid till läkarebesök eller åtgärd snabbare samt genom att öka friheten att välja sin läkare och vårdplats. Två av tre svarare ville få mera information om vårdens kvalitet och resultat (Teräväinen och Rönnberg 2008).

Sedan 1 mars 2005 har Finland haft vårdgaranti inom hälsovården. Patienterna skall få kontakt med hälsovårdscentralen under tjänstetiden från måndag till fredag. Vid behov skall besök till läkare eller sjuksötare ordnas inom tre dagar. Icke-brådskande primärvård skall ges inom tre 
månader. Vid behov av specialiserad hälsovård är tidfristen för läkarbesök tre veckor. Icke-brådskande vård skall ges inom sex månader. Inom barn- och ungdomspsykiatrin skall behandlingen börja dock inom tre månader.

THL följer efter tre gånger om år $(30.4,31.8$ och 31.12) hur hälsovårdscentraler och sjukvårdsdistrikten klarar av dessa tidsfrister. Rapportering inom primärvården innehåller hälsovårdscentralens öppenvård samt munnens hälsovård. I specialsjukvården rapporteras specialiteter separat, även psykiatrin. Som indikatorer för vuxenpsykiatri rapporteras andel klienter som har väntat på första besök 0-90, 91-180 eller över 180 dagar, andel klienter som har väntat på vård 0-90, 91-180 eller över 180 dagar samt antal klinter som har väntat på remiss 0-3, 4-21 eller över 21 dagar. Samma indikatorer används för barnpsykiatri och ungdomspsykiatri, men med kortare tidsfrister för första besök och vård (0-90 eller över 90 dagar). Länk till webbtjänster: http://www.thl.fi/web/fi/tutkimus/ tyokalut/erikoissairaanhoidon_hoitoonpaasy.

Stakes (numera THL) har sedan 1996 erbjudit färdiga blanketter för patientupplevd kvalitet i hälsovården. Tjänsten har även innehållit datainsamling och rapportering, som sjukhusen och sjukvårdsdistrikten har betalat själva. Enstaka resultat har därför inte publicerats.

I allmänhet har patienterna varit mycket nöjda med hälsovårdens tjänster. Till exempel för sjukhusvård år 2005-2006 varierade medelvärden i olika frågor mellan 3,9 och 4,6 med Likert-skala (min 1 mycket dåligt - max 5 mycket bra). Medelvärden har även ökat från 2001-2002 till 2005-2006 (Sainio och Räikkönen 2008).

Det finns separata enkäter för sjukhusvård (sedan 1995), poliklinisk vård (1997), vård vid hälsovårdscentralen (1998) och tandvård (2004). Blanketter för allmänläkare (1998) och för akutvård (2004) har använts mindre. Antal frågor varierar mellan 28 och 41. Det finns ingen specialblankett för psykiatri. (Sainio och Räikkönen 2008) $(20,21)$.

\subsubsection{Norge}

I Norge gjennomføres regelmessige brukererfaringsundersøkelser av Nasjonalt kunnskapssenter for helsetjenesten. Det gjøres fra 2-4 undersøkelser hvert år. På de viktigste feltene gjentas undersøkelsene hvert 3 år, slik at det er mulig å følge endringer over tid.

\section{Brukererfaringer med døgnenheter i psykisk helsevern}

Høsten 2005 gjennomførte Nasjonalt kunnskapssenter for helsetjenesten en spørreundersøkelse blant utskrevne brukere fra alle døgnenheter for voksne innen psykisk helsevern i Norge. Totalt har 2676 brukere besvart ulike spørsmål om sine erfaringer fra oppholdet. Undersøkelsen har en svarprosent på 35, og materialet gir ikke grunnlag for å oppgi resultat på institusjonsnivå. Den lave svarprosenten gjør at resultatene må tolkes med forsiktighet. 
Et hovedresultat fra undersøkelsen er at det er et forbedringspotensial på tjenesten brukerne har vurdert, noe man blant annet kan lese ut av resultatet på det vi har kalt hoveddimensjonen. Hoveddimensjonen er en gruppering av kjernespørsmål som er relevante for nesten alle brukerne. Disse kjernespørsmålene omhandler informasjon, behandlerrelasjon og behandling, og hoveddimensjonen gir en oppsummert skåre på hvor fornøyde brukerne er med disse viktige sidene av oppholdet. Det nasjonale gjennomsnittsresultatet på hoveddimensjonen er 51, på en skala fra 0 til 100 der 100 er beste resultat. Dette er et lavt resultat sammenlignet med andre pasienterfaringsundersøkelser. I en nasjonal undersøkelse hvor fastleger vurderte kvaliteten ved distriktspsykiatriske sentre var derimot resultatene stort sett på samme nivå eller dårligere enn i den foreliggende undersøkelsen.

Figur 2.26 viser svarfordelingen til de 8 enkeltspørsmålene som inngår i hoveddimensjonen. Spørsmålene er sortert slik at spørsmålene med størst andel positive svar står øverst.

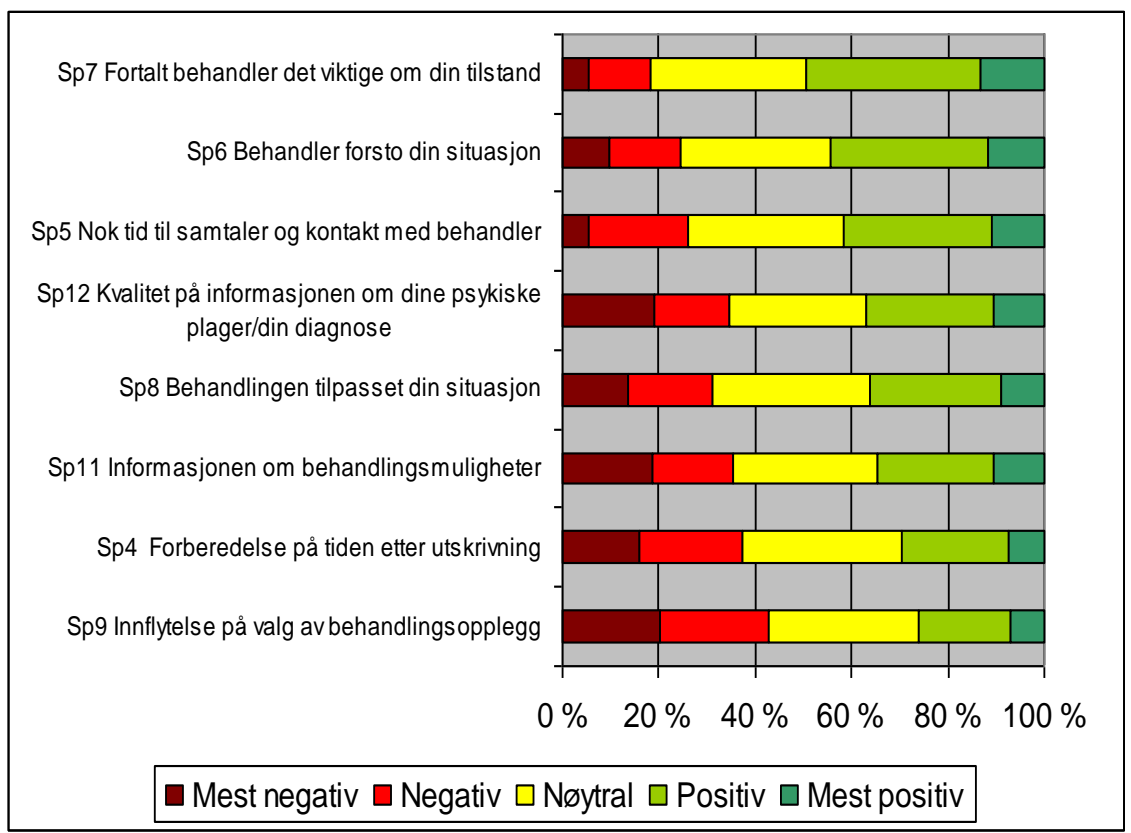

Figur 2.26: Nasjonale resultater for enkeltspørsmål som inngår i hoveddimensjonen

Note: Prosentandeler som har svart i de ulike svarkategoriene. Mest negativ svarkategori til venstre, mest positiv svarkategori til høyre.

Kilde: Rapport Nr 9 - 2006, Nasjonalt kunnskapssenter for helsetjenesten

Om man fikk fortalt det viktigste om sin tilstand og om behandleren forsto brukernes situasjon, var de emnene svarerne var mest fornøyd med, mens spørsmål som omhandlet forberedelse på tiden etter utskrivelse og innflytelse på valg av behandlingsopplegg fikk dårligst resultat. Rundt $40 \%$ svarte negativt på de to emnene som kom dårligst ut, mot rundt $20 \%$ negative svar på de to emnene som kom best ut. 
Andre tema som inngår i hoveddimensjonen er hva brukerne synes om kvaliteten på informasjonen de fikk om sine psykiske plager/sin diagnose, om behandlingen var tilpasset brukernes behov og om hva de synes om informasjonen om de behandlingsmuligheter som finnes for dem. Alle disse temaene hadde rundt $30 \%$ negative svar.

For ulike emner som ikke inngår i hoveddimensjonen er det relativt stor misnøye. Over $25 \%$ mente de hadde lite eller ikke noe utbytte av behandlingen, mente de ble behandlet nedlatende eller krenkende eller mente at utskrivningstidspunktet passet i liten grad eller ikke i det hele tatt. I alt $34 \%$ mente aktivitetstilbudet ved institusjonen var ganske eller svært dårlig. På to spørsmål som omhandlet informasjon om rettigheter svarte over $55 \%$ at de ikke hadde mottatt slik informasjon.

Det er små forskjeller mellom regionenes gjennomsnittskåre på hoveddimensjonen, og ingen er signifikant forskjellige fra landssnittet. Gjennomsnittskåren ligger rundt 50 for alle regionene. Det er noe større variasjon i resultat mellom de ulike helseforetakene og noen foretak er signifikant forskjellige fra landssnittet. For helseforetakene er beste gjennomsnittsresultat for hoveddimensjonen 65 mens det dårligste er 43.

Ulike bakgrunnsvariabler kan påvirke hvordan brukerne svarer. I den foreliggende undersøkelsen er blant annet gifte mer fornøyde enn enslige og samboende, og de som er innlagt mot sin vilje er mindre fornøyde enn andre. Det er også store forskjeller i fornøydhet mellom ulike diagnosegrupper; blant annet er personer med rusrelaterte lidelser mindre fornøyde enn andre.

\section{Foresattes vurderinger av tilbudet ved barne- og ungdomspsykiatriske poliklinikker}

Høsten 2006 gjennomførte Nasjonalt kunnskapssenter for helsetjenesten en spørreundersøkelse blant foresatte til barn og ungdom som mottar et tilbud fra barne- og ungdomspsykiatriske poliklinikker i Norge. Totalt har 7906 foresatte svart på en rekke spørsmål om sine erfaringer med tilbudet. Undersøkelsen har en svarprosent på 46 og representativiteten er tilfredsstillende. Det er utarbeidet tre rapporter fra undersøkelsen: en rapport med hovedresultater, en metoderapport og en rapport med institusjonsresultater.

De foresatte rapporterte i hovedsak positive erfaringer med de barne- og ungdomspsykiatriske poliklinikkene. Resultatene er oppsummert i tre hovedområder som handler om behandlerne, informasjon/medbestemmelse og utbytte. De nasjonale resultatene på disse hovedområdene varierte fra 59 for informasjon/medbestemmelse til 75 for behandlerne, på en skala fra 0 til 100, hvor 100 er best mulige resultat. Utbytte får en skår på 72 . Figur 2.27 viser resultatene for de enkeltspørsmålene som inngår i hvert hovedområde. 


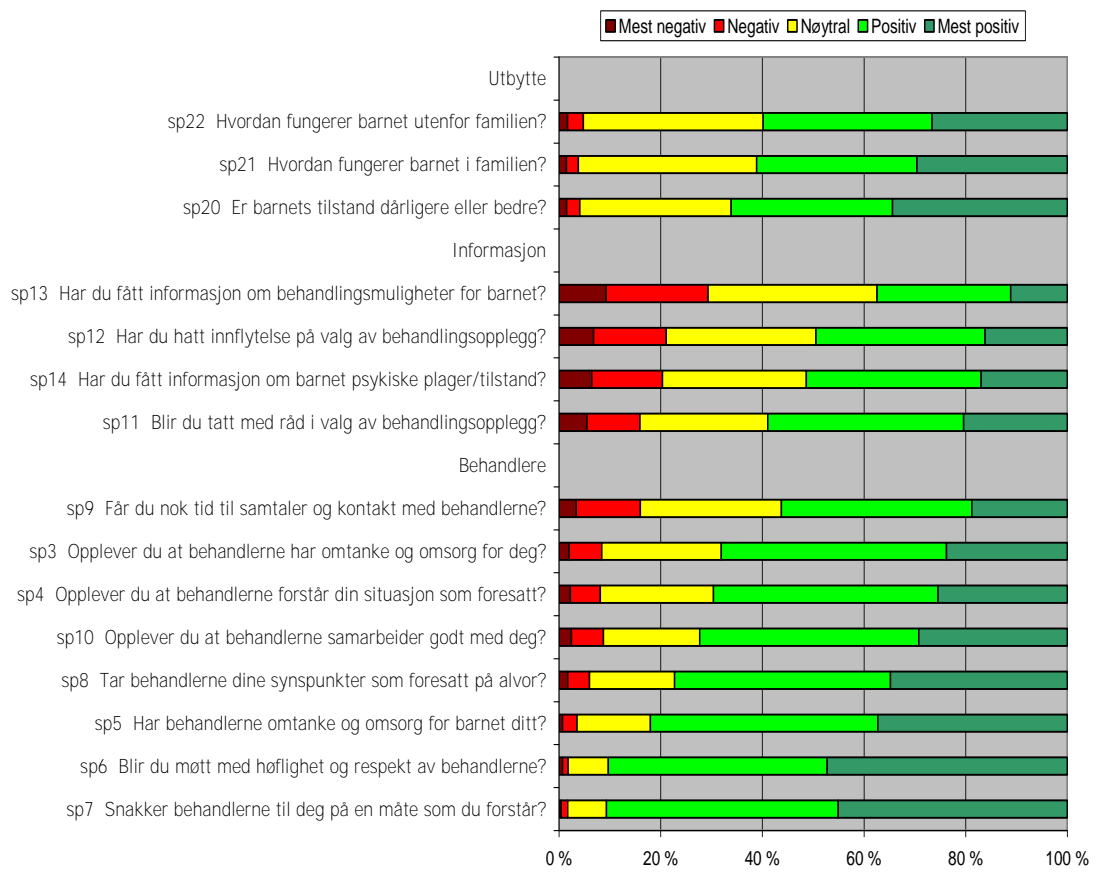

Figur 2.27: Nasjonale resultater på enkeltspørsmål som inngår i hovedområdene. Prosentandeler som har svart i de ulike svarkategoriene.

Kilde: PasOpp-rapport nr 2 - 2008, Nasjonalt kunnskapssenter for helsetjenesten

Som vist i figuren består hovedområdet utbytte av tre spørsmål som handler om endring i barnets tilstand og om funksjonsnivå innenfor og utenfor familien. I alle spørsmålene spørres det om hvordan barnet er nå sammenlignet med før behandlingen startet, med svarskalaer som går fra mye dårligere til mye bedre. Det er relativt liten variasjon i svarene mellom disse spørsmålene. På alle spørsmålene svarte mellom $33 \%$ og $40 \%$ at de ble mye dårligere, litt dårligere eller verken bedre eller dårligere nå enn før behandlingen startet. Spørsmålet som omhandler barnets tilstand får mest positive tilbakemeldinger.

Hovedområdet informasjon og medbestemmelse består av fire spørsmål som handler om hvorvidt de foresatte har fått informasjon om barnets tilstand og muligheter for behandling og i hvilken grad de foresatte ble tatt med på råd og hadde innflytelse på valg av behandling. Totalt sett er det dette hovedområdet som får dårligst resultat, men innad i hovedområdet er det noe variasjon i resultat mellom enkeltspørsmålene. Om de foresatte har fått informasjon om hvilke behandlingsmuligheter som finnes for barnet, får dårligst tilbakemeldinger. I alt svarte $62 \%$ at de i noen grad, liten grad eller ikke i det hele tatt hadde fått slik informasjon. Spørsmålet som får best tilbakemeldinger, får $41 \%$ svar på disse svarkategoriene, og handler om hvorvidt de foresatte blir tatt med på råd i valg av behandlingsopplegg. De resterende to spørsmålene får rundt 50 \% svar på disse svarkategoriene.

Hovedområdet behandlere, som består av 8 enkeltspørsmål, kom totalt sett best ut i undersøkelsen, men innad i hovedområdet er det en del varia- 
sjon i resultat mellom enkeltspørsmålene. De foresatte er minst fornøyd med tiden de får til samtaler og kontakt med behandlerne. Her har $16 \%$ svart at de i liten grad eller ikke i det hele tatt får nok tid, og $28 \%$ svarer «i noen grad». De to spørsmålene som kommer best ut er om de foresatte mener de ble mottatt med høflighet og respekt, og om behandlerne snakket til dem på en forståelig måte. På begge disse spørsmålene svarte bare 2 \% i de to mest negative svarkategoriene, og $8 \%$ svarte «i noen grad».

Foresatte $\mathrm{i}$ alle helseregioner hadde stort sett positive tilbakemeldinger, og det var små forskjeller mellom helseregionene. Helse Øst skåret signifikant bedre enn gjennomsnittet av de andre regionene på hovedområdene behandlere og informasjon/ medbestemmelse. Helse Midt-Norge hadde derimot en signifikant dårligere skåre enn gjennomsnittet av de andre helseregionene på hovedområdet behandlere. Også mellom de ulike helseforetakene er det små forskjeller, og få signifikante forskjeller. Det samme mønsteret gjør seg gjeldende her som i de nasjonale resultatene; behandlerne kommer best ut i alle helseforetakene, mens informasjon/medbestemmelse får det svakeste resultatet. Hovedområdet utbytte plasserer seg mellom disse to for alle helseforetakene.

På alle hovedområder var det stor spredning i resultat mellom de ulike poliklinikkene, størst spredning på informasjon/ medbestemmelse, hvor beste gjennomsnitt var 68 og dårligste 48 . Det var imidlertid få signifikante forskjeller mellom poliklinikkene og landssnittet på alle de tre hovedområdene.

De foresatte rapporterer altså gode erfaringer med poliklinikkene. Best tilbakemelding får behandlerne ved poliklinikkene, mens informasjon/medbestemmelse får dårligst tilbakemelding og er det området med størst forbedringspotensial.

\section{Brukererfaringer med poliklinikker for voksne i psykisk helsevern}

Nasjonalt kunnskapssenter for helsetjenesten gjennomførte høsten 2007 for andre gang en nasjonal spørreundersøkelse blant brukere av poliklinikker for voksne i psykisk helsevern i Norge. Forrige undersøkelse ble gjennomført i 2004. I 2007 deltok 100 poliklinikker i undersøkelsen, og totalt 11085 pasienter svarte på spørreskjemaet.

Undersøkelsen viser at brukerne har gode erfaringer med poliklinikkene på mange områder. Ett aspekt som brukerne hadde gode erfaringer med, er utbytte av samtaler med én behandler; $60 \%$ av brukerne rapporterte at de hadde stort eller svært stort utbytte av denne behandlingsformen. Brukerne er også spesielt godt fornøyd med behandlerne. Figur 2.28. viser at majoriteten av pasientene ga gode tilbakemeldinger på forhold knyttet til behandleren. Andelen fornøyde pasienter varierer mellom $60 \%$ og $74 \%$, og andelen negative pasiente mellom $7 \%$ og $14 \%$. Dårligst tilbakemelding gjelder i hvilken grad pasientene opplevde at behandlingen var tilpasset deres situasjon. Best tilbakemelding får behandlerne på pasientenes opplevelse av at de fikk fortalt til behandleren det som var viktig for dem: Her svarte $2 / 3$ av pasientene i undersøkelsen at dette skjedde i svært stor eller stor grad. 
Undersøkelsen viser også at poliklinikkene har et forbedringspotensial på flere områder. Spesielt gjelder dette medbestemmelse, informasjon og samarbeid med andre offentlige etater. For eksempel opplevde $23 \%$ at de ikke i det hele tatt eller kun i liten grad hadde innflytelse på sin medisinering, mens $25 \%$ oppga at informasjonen om behandlingsmuligheter var svært eller ganske dårlig. Når det gjelder eksternt samarbeid opplevde $30 \%$ av dem som svarte på spørsmålet at poliklinikken samarbeidet svært eller ganske dårlig med andre offentlige etater for å løse deres praktiske problemer.

Resultater for foretakene og poliklinikkene er sammenlignet på tre indikatorer, som omhandler brukererfaringer, opplevd ventetid og eksternt samarbeid. Det er betydelige forskjeller i resultater mellom forskjellige foretak og mellom forskjellige poliklinikker på disse indikatorene, spesielt når det gjelder opplevd ventetid.

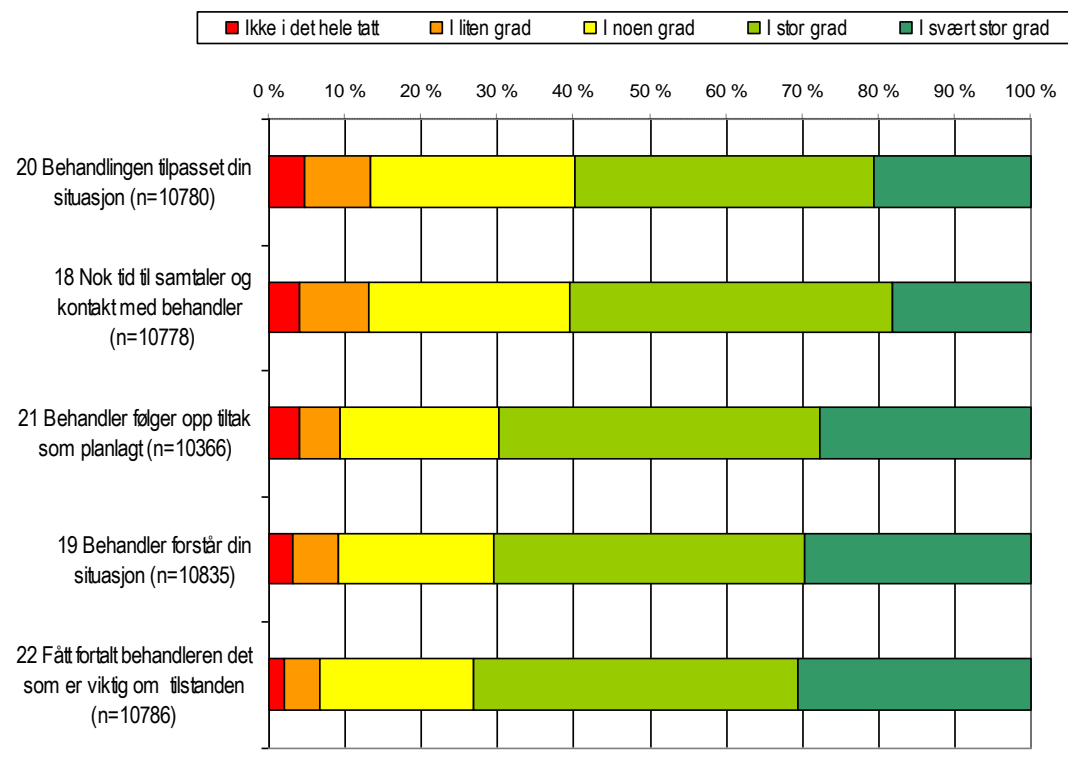

Figur 2.28: Om relasjon til behandleren.

Note: Prosentandel pasienter som har svart i de ulike svarkategoriene. Mest negativ i rødt til venstre, mest positiv svarkategori i grønt til høyre. Spørsmålene er sortert etter synkende andeler negative svar. Vektede resultater.

En sammenstilling av undersøkelsene fra 2007 og 2004 viser at de nasjonale resultatene er litt dårligere i 2007 enn i 2004. Dette gjelder på alle de tre indikatorene om brukererfaringer, opplevd ventetid og eksternt samarbeid. Denne utviklingen gjelder for alle regioner og de fleste helseforetak, men det er flere poliklinikker som har hatt en positiv utvikling på en eller flere indikatorer fra 2004 til 2007.

Fastlegers vurderinger av distriktspsykiatriske sentre

I 2005 foreslo en nasjonal arbeidsgruppe for kvalitetsindikatorer i psykisk helsevern «Tilfredshet med samarbeidspartnere» som en kvalitets- 
indikator. Viktige drivkrefter var et ønske om å forbedre de nasjonale kvalitetsindikatorene for psykisk helsevern samt å styrke samarbeidet mellom primær- og spesialisthelsetjenesten. Utviklingsprosjektet ble vedtatt av Helse- og omsorgsdepartementet og ble utført av Nasjonalt kunnskapssenter for helsetjenesten. Kunnskapssenteret avgrenset prosjektet til å gjelde fastlegers tilfredshet med distriktspsykiatriske sentre (DPS).

Det ble gjennomført et FoU-prosjekt hvor formålet var å utvikle en vitenskapelig robust metode for å måle og sammenligne fastlegers erfaringer og tilfredshet med DPS-ene, for å underbygge bruken av resultatene i kvalitetsforbedring, virksomhetsstyring og i samfunnet for øvrig, inkludert pasienters rett til fritt sykehusvalg. Spørreskjema og datainnsamlingsopplegg ble utviklet og validert. I tillegg ble hensiktsmessigheten av å bruke aggregerte senterresultater som nasjonale kvalitetsindikatorer undersøkt.

\section{Resultater}

Kunnskapssenteret gjennomførte undersøkelsen høsten 2008 for andre gang. Forrige undersøkelse ble gjennomført i 2006. I 2008 deltok 80 DPS-er i undersøkelsen og totalt 2209 fastleger svarte på spørreskjemaet. 2008-undersøkelsen viste at fastlegene er mest fornøyde med kvaliteten på epikrisene, DPS-enes kompetanse og om DPS-ene tar fastlegenes vurderinger på alvor. $54 \%$ av fastlegene oppga at epikrisene fra det lokale DPS-et var av god kvalitet. $50 \%$ mente at DPS-et hadde god kompetanse til å utrede og behandle pasienter med psykiske lidelser og $52 \%$ opplevde at det lokale DPS-et tok deres vurderinger på alvor.

Undersøkelsen viser også at DPS-ene har et forbedringspotensial på en del områder. Ifølge fastlegene gjelder dette spesielt samarbeidsmøter og veiledningstilbud, legedekningen ved DPS-ene og tilbakemeldinger underveis i utrednings- og behandlingsprosesser. $68 \%$ av fastlegene mente at det lokale DPS-et i liten eller ingen grad tilbød organisert veiledning og fagdager med god kvalitet. $59 \%$ oppga at de i liten eller ingen grad hadde samarbeidsmøter med DPS-et. $56 \%$ mente at de i liten eller ingen grad fikk nødvendig tilbakemelding fra DPS-et underveis i utrednings- og behandlingsprosesser og $50 \%$ mente at DPS-et i liten eller ingen grad hadde god legedekning.

Resultater for og DPS-ene og samlede resultater for helseforetakene (som eier DPS-ene) i 2008 er sammenlignet på seks indekser: akutte situasjoner, veiledning, kompetanse, bemanning, epikrise og ventetid. Det er betydelige forskjeller mellom forskjellige foretak og mellom forskjellige DPS-er på disse indeksene, spesielt når det gjelder beman-ning og veiledning. Resultatene er fremstilt grafisk i figur 2.29 nedenfor.

En sammenstilling av undersøkelsene fra 2008 og 2006 viser at endringene i perioden er små. Imidlertid har veiledningsindeksen en signifikant økning på 3 poeng (på en skala fra 0 til 100 der 100 er best), og tilsvarende har fastlegenes generelle tilfredshet med DPS-ene en signifikant $ø$ kning på 2 poeng. Det er få signifikante endringer på indeksene på region- og helseforetaksnivå, men mange endringer på DPS-nivå på indek- 
sene for veiledning og bemanning. Undersøkelsen gjentas for tredje gang våren 2011. Figuren nedenfor viser resultatene for de enkelte DPS-ene.

\section{Perspektiver}

Den norske opptrappingsplanen for psykisk helse (1999-2008) har medført større kapasitet og flere tjenester, men det finnes få forskningsbaserte metoder for å måle kvaliteten og kvalitetsutviklingen på nasjonalt nivå. Spørreskjemaet er nå tilgjengelig som et verktøy for å måle og monitorere tjenestekvaliteten ved DPS-ene, for ulike formål og målgrupper.

Både Helsetilsynet (2008-2009) og Riksrevisjonen (2008) har konkludert med varierende og til dels dårlig kvalitet ved, og tilgjengelighet til, DPS-ene. Dette er i tråd med de målingene vi har gjennomført av fastlegenes erfaringer og vurderinger. Samsvar mellom fastlegers vurderinger og kliniske indikatorer bør undersøkes, men de eksterne evalueringene av DPS-ene referert ovenfor er konsistente og gir grunnlag for en hypotese om en positiv sammenheng mellom kliniske indikatorer og fastlegeindikatorene. 


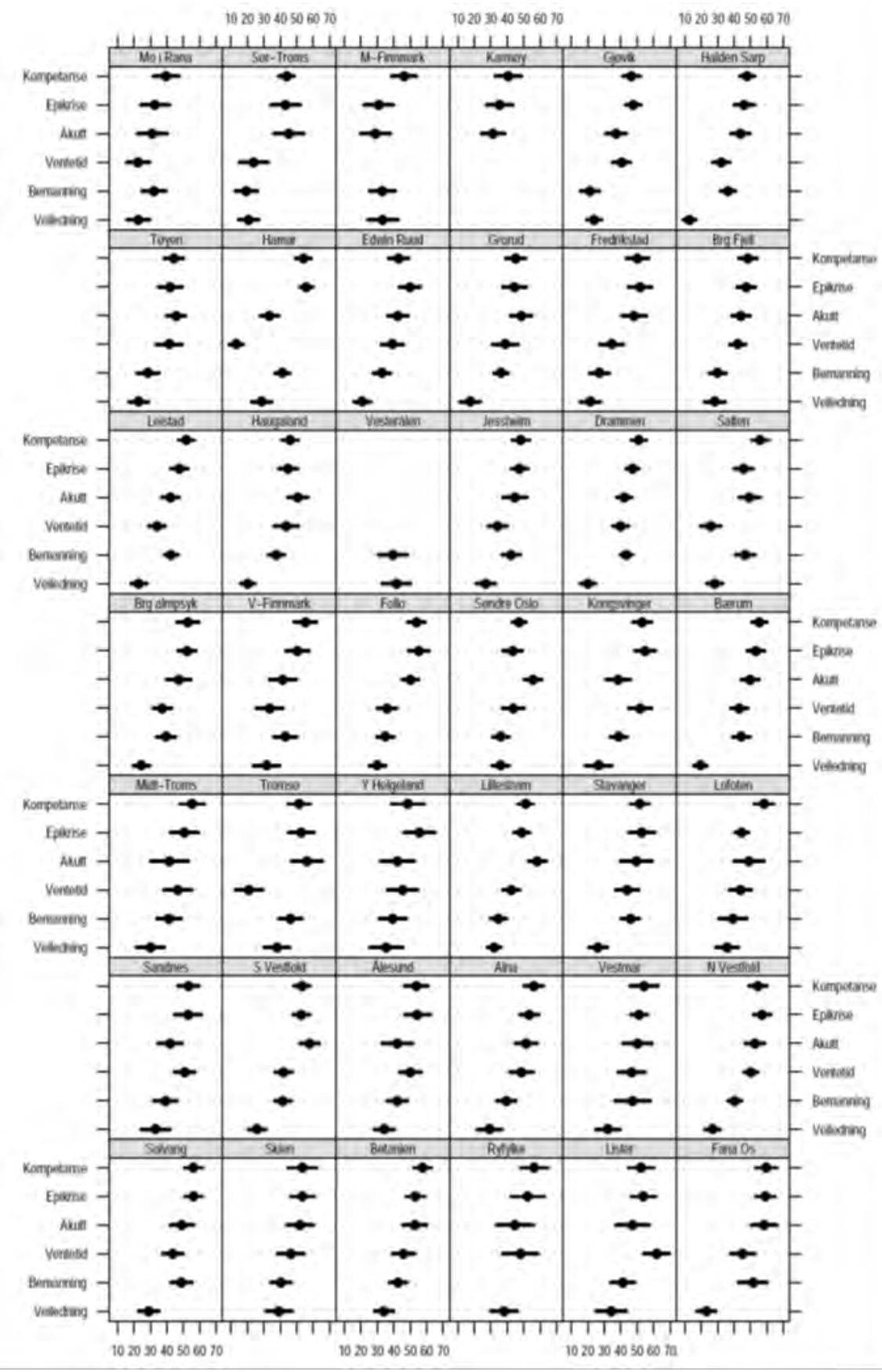

Figur 2.29: Gjennomsnittsskårer på indeksene for hvert DPS i 2008, samt konfidensintervaller. Sortert etter DPS. Skala 0 til 100 der 100 er best

\subsubsection{Sverige}

Nationell patientenkät för patienter inom öppen och sluten psykiatrisk vård

Den första nationella patientenkäten för patienter inom öppen respektive sluten psykiatrisk vård (vuxen) genomfördes i Sverige under våren 2010. Sveriges Kommuner och Landsting (SKL) samordnade undersök- 
ningen, som en del inom projektet Nationell Patientenkät, på uppdrag av alla landsting och regioner. Resultatet finns publicerat på hemsidan för det företag som SKL har givit i uppdrag att genomföra enkätundersökningarna (www.indikator.org/publik). En majoritet av landstingen i Sverige genomförde mätning inom psykiatrin 2010. Från och med 2011 deltar alla landsting och regioner i Nationell Patientenkät. Nästa nationella mätning inom psykiatrin sker under våren 2012.

Svarsfrekvensen för enkäten var, efter korrigeringar, cirka $43 \%$ inom den öppna psykiatriska vården och ca $35 \%$ inom den slutna. Antalet svarande var drygt 16700 personer respektive drygt 2100 personer.

\section{Hur presenteras resultaten?}

Frågeformuläret innehåller ett antal delområden som speglas genom ett flertal frågor, sammanlagt cirka 60 för den öppna vården och cirka 50 stycken för slutenvården. Resultatet redovisas genom att sju indikatorer, som består av enskilda frågor med olika perspektiv, lyfts fram för riket samt per landsting/region. De sju indikatorer består av perspektiven; bemötande, delaktighet, information, tillgänglighet, förtroende, upplevd nytta och om vården kan rekommenderas. Resultatet för respektive indikator sammanfattas i ett viktat värde som benämns "patientupplevd kvalitet", på landstings- respektive riksnivå. På den webbsida där resultaten presenteras redovisas även resultaten för samtliga frågor i enkäten.

Endast frågor som faktiskt besvarats (giltiga svar) ingår i värdet (patientupplevt kvalitetsvärde). Varje svarsalternativ har viktats i förhållande till sin allvarlighetsgrad. För att räkna fram värdet används följande formel:

\section{Vikt x Antal svar per frågealternativ}

Giltiga svar

Vikten kan vara 0, 0,25, 0,5, 0,75 eller 1 . Resultaten från varje svarsalternativ adderas, multipliceras med 100 och avrundas till närmaste heltal mellan 0 och 100.

\section{Resultat}

I nedanstående tabell sammanfattas resultaten av den patientupplevda kvaliteten på riksnivå, för öppen respektive slutenvård.

\begin{tabular}{lrr} 
Tabel 2.11.2: Patientupplevd kvalitet & \\
\hline Delområde/indikator & $\begin{array}{r}\text { Patientupplevd kvalitet (0-100) } \\
\text { oppenvård }\end{array}$ & $\begin{array}{r}\text { Patientupplevd kvalitet(0-100) } \\
\text { slutenvård }\end{array}$ \\
\hline Bemötande & 84 & 71 \\
Delaktighet & 67 & 54 \\
Information & 67 & 59 \\
Tillgänglighet & 60 & 60 \\
Förtroende & 71 & 68 \\
Upplevd nytta & 75 & 66 \\
Rekommendera & 78 & 68
\end{tabular}


Resultaten pekar på att respondenterna upplever ett gott bemötande och har förtroende för personalen. De förbättringsområden som patienterna framförallt pekar på är tillgängligheten och delaktigheten. I rapporten kan också utläsas att man pekar på vikten av en långsiktighet $\mathrm{i}$ vårdplaneringen samt en tydligare information om tidiga tecken att vara uppmärksam på beträffande sjukdomen eller behandlingen. Andra områden som lyfts fram är brist på information om läkemedelsbiverkningar och vart man vänder sig för att få kontakt med stödgrupper eller för att klaga på sin vård.

Resultaten i den aktuella undersökningen ligger betydligt lägre än resultaten inom den specialiserade sjukhusvården samt primärvård.

\subsection{Kvalitetsindikatorer under udvikling i de nordiske lande}

\subsubsection{Danmark}

Det Nationale Indikatorprojekt (NIP) i Danmark, som blev etableret i 2000. NIP monitorer kvaliteten af behandlingen af patienter med skizofreni og depresision i Danmark. Der er obligatorisk deltagelse for alle danske hospitaler, der behandler patienter med skizofreni og depression. De respektive hospitalsafdelinger skal således sende data til NIP for alle patienter de behandler med skizofreni og depression. Kvalitetsindikatorerne, der indgår i NIP afspejler henholdsvis det nationale referenceprogram for skizofreni og det nationale referenceprogram for depression i Danmark. Fra 2011 er implementeringen af nationale indikatorer for depression påbegyndt i Danmark som led i NIP.

Tabel 2.12.1 illustrerer indikatorer for depression i Det Nationale Indikatorprojekt (NIP), som implementeres i det danske sundhedsvæsen. 
Andelen af indlagte patienter, med depression der vurderes ved speciallæge i psykiatri inden for 7 dage efter indlæggelsesdatoen på psykiatrisk afdeling

Andelen af indlagte patienter, hvor der er foretaget initial somatisk udredning inden for 2 dage fra indlæggelsesdatoen

Andel af indlagte patienter, der er unders $\varnothing$ gt for selvmordsrisiko ved indlæggelse på psykiatrisk afdeling Andelen af indlagte patienter hvor patienten vurderes vedr. sociale støttebehov senest ved udskrivelse fra psykiatrisk afdeling

Andelen af indlagte patienter, hvor pårørende tilbydes kontakt med henblik på inddragelse senest ved udskrivelse fra psykiatrisk afdeling

Andelen af indlagte patienter, hvor der er aftalt planlagt opfølgning ved udskrivelse fra psykiatrisk afdeling. Andelen af indlagte patienter, der er unders $\emptyset \mathrm{gt}$ for selvmordsrisiko når udskrivelse aftales med psykiatrisk afdeling

Andelen af ambulante patienter, hvor der er givet tilbud om psykoterapi senest 90 dageefter 1. ambulante bes $\varnothing \mathrm{g}$

Andelen af indlagte patienter, der genindlægges indenfor 30 dage efter udskrivelse fra psykiatrisk afdeling Andelen af ambulante patienter, der vurderes ved speciallæge i psykiatri senest 30 dage efter 1 . ambulante kontakt

Andelen af ambulante patienter, der er undersøgt for selvmordsrisiko ved 1. ambulante kontakt

Andelen af ambulante patienter, hvor patienten udredes for sociale støttebehov senest ved afslutning af ambulant forløb

Andelen af ambulante patienter, hvor pårørende tilbydes kontakt med henblik på inddragelse senest 90 dage efter 1. ambulante kontakt

Andelen af ambulante patienter, som får vurderet depressionssværhedsgraden ved Hamiltons Depressionsskala (HAM-D17) senest 30 dage efter 1. ambulante bes $\varnothing \mathrm{g}$

Andelen af ambulante patienter der har fået vurderet depressionssværhedsgraden ved Hamiltons Depressionsskala (HAM-17) ved afslutning af ambulant forløb

\subsubsection{Finland}

I Finland finns det bara enstaka separata kvalitetsregistren, till exempel implantationsregister (THL) och njursjukdomsregister (Lever- och njurförbundet r.f.). Den främsta orsaken för låga antalet är den nuvarande lagstiftningen om hälsovårdens nationella personregister, som begränsar möjligheter att grunda nya nationella register. Det finns ett större behov att förnya lagstiftningen. En arbetsgrupp med ledning av socialoch hälsoministeriet kommer att börja sitt arbete på hösten 2011. Arbetsgruppen kommer att kartlägga behovet för nya register i Finland, inklusive kvalitetsregister.

Det finska hälsoinformationssystemet samlar in och publicerar olika kvalitetsindikatorer. Till exempel cancerregistret publicerar dödlighetsoch överlevnadstal, vårdanmälningsregister för hälsovården information om tvångsvård i psykiatrin och födelseregistret information om vissa komplikationer under förlossningen. Dessa kvalitetsindikatorer publiceras separat, och bara enstaka kvalitetsindikatorer rapporteras i det nationella indikatorssystemet för social- och hälsovården SOTKAnet: http://uusi.sotkanet.fi/portal/page/portal/etusivu

I mars 2011 öppnades pilotversionen av en ny webbtjänst för tillförlitliga uppgifter och jämförelser inom social- och hälsovårdens tjänster. Palveluvaaka.fi - portalen erbjuder information om hur servicen inom social- och hälsovården fungerar. Olika verksamhetsenheter kan jämföra 
sinsemellan och användarna kan betygsätta den service som de har använt. Informationssystemet visar även detaljerad statistik inom socialoch hälsovården. Webbtjänsten utvecklas i samarbete med aktörer inom social- och hälsovården.

I början innehåller webbtjänsten uppgifter om hälsovårdstjänsterna och omsorgstjänsterna för äldre vid ålderdomshem och servicehus. I fortsättningen kommer webbtjänstens innehåll att kompletteras i takt med att jämförbara uppgifter finns att fă. Detta gäller även psykiatrin. Palveluvaaka: http://www.palveluvaaka.fi/sv/web/guest/.

\section{Arbetsgruppen Mieli 2009}

Finland publicerade sin nationella plan för psykisk hälsa och missbruksarbete år 2009. Social- och hälsoministeriets plan innehåller 18 förslag till gemensam utveckling av arbetet för psykisk hälsa och missbruksarbetet fram till år 2015. Verkställandet skall rapporteras årligen. I planen läggs särskild vikt vid att stärka klientens ställning och att effektivera arbetet för att främja psykisk hälsa och alkohol- och drogfrihet samt åtgärderna för att förebygga problem och skadeverkningar. Vidare framhålls att servicesystemet bör utvecklas så att större vikt läggs vid basservicen och öppenvården, som ska bli bättre på att samtidigt beakta psykiska problem och missbruksproblem. Planen omfattar också styrmedel för genomförandet av planen. I augusti 2011 publiceras den första årsrapport, som granskar det mottagande planen fått och hur verkställandet av planen har framskridit.

I den huvudsakligen finskspråkiga rapporten granskas det aktuella läget i utvecklingen av social-, hälso- och sjukvården. Rapporten behandlar centrala utmaningar inom social-, hälso- och sjukvården, teman som anknyter till brukarexperter och kamratstödjare och nya kombinerade tjänster avsedda för personer med psykiska problem och missbruksproblem. Även de omfattande nationella hälsoprojekten (Kasteprojekt om mentalvårds- och missbruksarbete samt Masto-projekt för att förebygga depression hos personer i arbetsför ålder) presenteras.

I anslutning till den nationella planen redovisar THL sina nio spetsprojekt:

1. att stärka verksamhet med kamratstöd och brukarexperter

2. att minska användningen av tvång vid psykiatriska sjukhus

3. att göra kombinerade strategier för psykisk hälsa och missbruksarbete till en del av kommunernas välfärdsplaner

4. att utveckla och förankra arbetsmetoder som syftar till att förhindra och minska att psykiska problem och missbruksproblem går i arv från en generation till en annan

5. att utveckla mentalvårds- och missbrukartjänster med låg tröskel inom basservicen

6. att följa upp tillgången och kvaliteten på mentalvårds- och missbrukartjänster som motsvarar kommuninvånarnas behov

7. att upprätthålla en webbportal (www.thl.fi/mielijapaihde) 
8. att centralisera den nationella samordningen av utvecklingen inom det förebyggande mentalvårds- och missbruksarbetet och

9. att ge stöd i beredningen av lagstiftningen

Planen omfattar också styrmedel för genomförandet av planen. I augusti 2011 publiceras den ANDRA årsrapport, som granskar det mottagande planen fătt och hur verkställandet av planen har framskridit (22).

\subsubsection{Grønland}

En oprustning af datatilgængelighed var en af hovedanbefalingerne i redegørelsen på det psykiatriske område fra 2010. Der er i dag kun få indikatorer på sundhedsområdet, der findes valide data på. En udbygning af indikatorer for psykisk sygdom med hensyntagen til de særlige forhold i Grønland er en nødvendighed, men må afvente bedre data.

\subsubsection{Island}

Der er ikke specielt nationelt projekt med at udvikle kvalitetsindikatorer í Island undtagen í det internationelle samaarbejd.

\subsubsection{Norge}

St.meld nr 25 (1996-1997) «Åpenhet og helhet; Om psykiske lidelser og tjenestetilbudene» var bakgrunnen for gjennomføring av Opptrappingsplanen for psykisk helse (1998-2008). Målet for opptrappingsplanen var større åpenhet om psykiske lidelser, forebygging, desentralisering og mest mulig frivillighet.

Gjennom opptrappingsplanen har tjenestene i det psykiske helsevernet gjennomgått en desentralisering. Det er bygd ut distriktspsykiatriske sentra (DPS) og poliklinikker i psykisk helsevern for barn og unge (BUP). Alle kommuner i Norge tilhører opptaksområde til et DPS og en BUP. Kapasiteten i tjenestene både for voksne og barn og unge er vesentlig styrket i løpet av planperioden, slik at flere făr behandling.

Tall fra SAMDATA viser at det psykiske helsevernet ved utgangen av 2009 ga et tilbud til nærmere $5 \%$ av barn og unge i alderern 0-17 år, i tråd med målet i opptrappingsplanen.

\section{Nytt rammeverk for kvalitetsindikatorer i Norge}

Til tross for store investeringer de senere årene for å sikre en helse- og omsorgstjeneste av god kvalitet, både i form av store reformer, ulike lovendringer og betydelig økonomisk satsing, mangler vi sammenlignbare data om kvaliteten for store deler av tjenesten. Informasjonen som samles inn er stort sett knyttet til helseøkonomiske investeringer og resultater i form av aktivitet og produktivitet.

På nesten alle andre områder mangler Norge systematisk informasjon på overordnet nivå om hva slags behandling pasientene har fått, 
hvilken kvalitet disse tjenestene har og hvilke behandlingsresultater man oppnår.

\section{Utvikling}

Helsedirektoratet har som fagmyndighet et overordnet ansvar for etablering og videreutvikling av det nasjonale kvalitetsindikatorsystemet for primærhelsetjenesten og spesialisthelsetjenesten. På bakgrunn av en rapport fra Kunnskapssenteret har direktoratet i 2010 utarbeidet et rammeverk for et nasjonalt kvalitetsindikatorsystem i helsetjenesten. Rammeverket består av 14 punkter.

http://www.helsedirektoratet.no/vp/multimedia/archive/00319/R ammeverk_for_kvali_319359a.pdf

Rammeverket beskriver hvem målingene er ment for og hvordan de skal brukes, hvilke kvalitetsaspekter som skal måles og på hvilken måte. Rammeverket skal ikke anvise hvilke kvalitetsindikatorer som skal inngå, men gi prinsipielle retningslinjer og avklaringer.

I Norge skjer det også mye faglig godt utviklingsarbeid gjennom de nasjonale faglige retningslinjene; kunnskapsgrunnlaget som disse bygger på er solid, og personer som benyttes i utarbeidelse er svært kompetente. Som grunnlag for utvikling av kvalitetsindikatorer betyr det at man allerede vil ha et godt kunnskapsgrunnlag og et godt utgangspunkt for de konsensusprosesser som er nødvendige i henhold til rammeverket for kvalitetsindikatorsystemet.

\section{Perspektiver}

I Nasjonal helse- og omsorgsplan(2011-2015) påpekes det at det er et mål å etablere et nasjonalt kvalitetsindikatorsystem som skal gi pålitelig kunnskap om sikkerhet, kvalitet og ytelser i alle deler av helsetjenesten. Det skal legges vekt på å inkludere indikatorer på sosiale forskjeller i tilgjengelighet og bruk og resultat av helsetjenester.

Informasjonen skal brukes til kvalitetsforbedringsarbeid, til politisk styring, virksomhetsstyring, og til forskning. Systematisk kvalitetsforbedringsarbeid forutsetter at ledelsen har oversikt over kvalitet og pasientsikkerhetsnivå i virksomheten, at resultatene brukes til å iverksette tiltak og at tiltakene følges opp og etterspørres. Helse- og omsorgsdepartementet vil derfor understreke ansvaret i styringsdialogen med de regionale helseforetakene, og legge flere styringskrav knyttet til kvalitet og pasientsikkerhet.

\section{Psykisk helsevern i Norge}

I tildelingsbrev fra Helse- og omsorgsdepartementet 2011 er Helsedirektoratet gitt i oppdrag å videreutvikle indikatorer og styrings-variable som i fremtiden setter nasjonale helsemyndigheter bedre i stand til å overvåke og å sette gode resultatmål for tjenesten. 


\section{Utvikling/resultater}

I Norge har man siden 2005 publisert kvalitetsindikatorer innen psykisk helsevern i det nasjonale kvalitetsindikatorsystemet. I første rekke er det indikatorer for psykisk helsevern barn og unge. For psykisk helsevern voksne har det vært store utfordringer knyttet til datakvalitet og kun et fåtall av de som er basert på manuell rapportering har til nå vært publisert.

Fordi data og registreringsrutiner ikke er tilfredsstillende, har det også blitt satt i gang et arbeid med å gjøre forbedringer. Bl.a. har Norsk pasientregister(NPR) satt i gang egen kvalitetsforbedringsstrategi (2011-2014). Videre har Helse- og omsorgsdepartementet i oppdragsdokument 2011 til de regionale helseforetak lagt inn 3 nye indikatorer som skal bidra til å bedre datakvaliteten innen psykisk helsevern. Dette er kvalitetsindikatorer som vil bli brukt i styringsdialogen i 2011, se tabell nedenfor.

\begin{tabular}{|c|c|c|}
\hline $\begin{array}{l}\text { Indikator } \\
\text { Indicator }\end{array}$ & $\begin{array}{l}\text { Det som blir malt } \\
\text { What is measured }\end{array}$ & $\begin{array}{l}\text { Status } \\
\text { Status }\end{array}$ \\
\hline $\begin{array}{l}\text { Registrering av lovgrunnlag - } \\
\text { psykisk helsevern voksne } \\
\text { Recording of legal basis - adult } \\
\text { psychiatry } \\
\text { Registrering av hovedtilstand - } \\
\text { psykisk helsevern voksne } \\
\text { Recording of main condition - } \\
\text { adult psychiatry }\end{array}$ & $\begin{array}{l}\text { Andel registrering av hoveddiag- } \\
\text { nose for alle utskrevne pasienter } \\
\text { og pasienter med minst } 6 \text { direkte } \\
\text { kontakt med spesialisthelsetjenes- } \\
\text { ten. } \\
\text { Ratio of recorded main diagnosis } \\
\text { of all discharged patients and } \\
\text { patients with a minimum of } 6 \\
\text { (face-to-face) contacts with the } \\
\text { specialist health care. }\end{array}$ & $\begin{array}{l}\text { (årstall fra 2010) } \\
\text { Publisering før sommer } 2011 . \\
\text { http://nesstar2.shdir.no/kvalind/ } \\
\text { (Date, year 2010). Being published } \\
\text { early summer 2011. } \\
\text { http://nesstar2.shdir.no/kvalind/ } \\
\text { (3. tertial 2010) } \\
\text { Publisering før sommer 2011. } \\
\text { http://nesstar2.shdir.no/kvalind/ } \\
\text { (3. tertial 2010) Being published } \\
\text { early summer 2011. } \\
\text { http://nesstar2.shdir.no/kvalind/ } \\
\text { (Årstall 2010) } \\
\text { Publisering før sommer 2011. } \\
\text { http://nesstar2.shdir.no/kvalind/ } \\
\text { (Date, year 2010) Being published } \\
\text { early summer 2011. } \\
\text { http://nesstar2.shdir.no/kvalind/ }\end{array}$ \\
\hline
\end{tabular}

Når det gjelder indikatorene som er publisert nasjonalt, spesielt innen psykisk helsevern barn og unge har man sett en gradvis positiv utvikling. Både for $\varnothing \mathrm{kt}$ andel av utsendte epikriser etter behandlingsslutt, kortere ventetid til behandling og økt fokus på registrering av diagnoser. Selv om ventetiden har gått noe ned i løpet av de siste årene er det likevel fortsatt stor $\mathrm{k} \emptyset$ for de som ønsker behandling. I Norge fikk man derfor $\mathrm{i}$ 2008 en innskjerpelse av ventetidsgarantien, noe som gjorde at alle barn og unge har rett til behandling innen 3 mnd. Sykehus som ikke klarer dette kravet risikerer å måtte kompensere for sykehusbehandling som pasienten foretar ved annet sykehus. I tillegg har helsemyndighetene arbeidet med å få fram riktig og presis informasjon om tilgjengelighet og ventetid på sykehus for mange behandlingstjenester, både for somatikk og psykisk helsevern. 


\section{Perspektiver}

Innen psykisk helsevern og tverrfaglig spesialisert rusbehandling (TSB) er det opprettet en nasjonal strategigruppe der alle de regionale helseforetakene i Norge er representert. Gruppen skal beskrive det som kjennetegner godt psykisk helsevern og behandling av ruslidelser. Videre skal det defineres adekvate og gjennomgående kvalitetsindikatorer som skal supplere dagens nasjonale indikatorer.

Strategigruppen arbeider med å utvikle nye kvalitetsindikatorer og skal ha særskilt fokus på resultatindikatorer. Det er også aktuelt å foreslå nye kvalitetsindikatorer knyttet til prosess

I Norge arbeides det spesielt med å belyse kvalitet og kritiske målepunkt gjennom å se på pasientforløp. Sentralt tema er timing, dvs tiltak til rett tid, på rett nivå, og koordinert med god samhandling. Kunnskapsbasert praksis og brukerkompetanse er avgjørende som grunnlag for tiltakene. Det arbeides med en systematisering av brukererfaring knyttet til pasientens evaluering av innholdet $i$ behandlingen.

Det er spesielt uttrykt et behov for å innføre kvalitetsindikatorer tilsvarende de man har innen psykisk helsevern, også for rusfeltet. Her arbeides det med å utarbeide indikatorer som beskriver ventetid, individuell plan, avbrudd i behandling, utsendelse av epikrise etter avsluttet behandling, osv. Det arbeides også med å se på behandlingsplan og prosentandel som oppnår remisjon etter behandling.

\subsubsection{Sverige}

Det pågår ett omfattande arbete med att ta fram indikatorer inom hälsooch sjukvården och socialtjänstens område på Socialstyrelsen. Arbetet ska leda till ett enhetligt nationellt system för uppföljning inom psykiatriområdet. Flera indikatorer har tagits fram inom ramen för arbetet med Nationella riktlinjer. Dock saknas datakällor för ett flertal av indikatorerna, varav att man i nuläget klassificerat dem som utvecklingsindikatorer.

\section{Utvecklingen av nationell uppföljning inom psykiatriområdet}

Socialstyrelsen har regeringens uppdrag att påskynda utvecklingen av grunddata och kvalitetsindikatorer samt att förbättra verksamhetsuppföljningen inom psykiatriområdet. Syftet är att få till stånd en regelbunden redovisning av psykiatrins och socialtjänstens verksamhet och insatser för personer med psykisk sjukdom eller funktionsnedsättning. Huvudmålet för arbetet är att utforma ett system för nationell uppföljning för att fortlöpande ge en bild av tillståndet inom psykiatriområdet på ett antal strategiska uppföljningsområden. Uppdraget genomförs i ett antal delprojekt som relateras till fyra utvecklingsområden: 
- Utveckling och förbättring av grunddata och andra informationskällor

- Utveckling av indikatorer, mått och variabler inom hälso- och sjukvården samt socialtjänst

- Utveckling av modeller för att beskriva strukturer, processer, kostnader och resultat samt en metodik för att analysera och utvärdera kvalitet och effektivitet i verksamheterna för personer med psykisk sjukdom eller funktionsnedsättning

- Utarbeta former för att fortlöpande rapportera om tillståndet inom psykiatriområdet samt hur en kontinuerlig dialog med beslutsfattare, verksamhetsföreträdare samt med patienter, klienter och anhöriga ska utformas.

Uppdraget ska presenteras för regeringen senast den 1 juli 2012. 
Tabel 2.12.3. Översikt för utvecklingsindikatorer

Depression
Bedömning av beroendeproblematik med strukturerad intervju för patienter med diagnosen depression eller
bipolär sjukdom
Läkemedelsbehandling och diagnossättning av depression
Interventioner med sammansatta vårdåtgärder och samverkan
Kontinuitet i läkarkontakten (telefon eller besök) för patienter med egentlig depressionsepisod, eller bipolär
sjukdom
Internetbaserad KBT-behandling med behandlarstöd för patienter med egentlig depressionsepisod
Uppföljning via telefon eller återbesök minst två gånger första månaden efter att läkemedelsbehandling satts in
Psykologisk behandling med KBT vid egentlig depressionsepisod
Internetbaserad KBT-behandling med behandlarstöd för patienter med egentlig depressionsepisod

Schizofreni

Varaktig boendelösning för personer med psykisk funktionsnedsättning Hemlöshet hos personer med psykisk funktionsnedsättning

Uppföljningskontakt i öppenvården efter utskrivning från slutenvård

Avbrutna åtgärder

Gemensam psykopedagogisk utbildning till patient med schizofreni och anhöriga

Psykologisk behandling med KBT vid schizofreni

Förekomst av individuell och samordnad plan för personer med schizofreni

Årlig uppföljning av åtgärder för personer med schizofreni med stöd av etablerade instrument för bedömning och uppoöljning

Förekomst av individuell och samordnad plan för personer med psykisk funktionsnedsättning

Årlig uppföljning av åtgärder för personer med psykisk funktionsnedsättning med stöd av etablerade instrument

för bedömning och uppföljning

Kostnad per patient i psykiatrisk öppenvård

Kostnad per patient i psykiatrisk sluten vård

Andel patienter med schizofreni eller schizofreniliknande tillstånd i psykiatrisk öppenvård

Andel patienter med schizofreni eller schizofreniliknande tillstånd / psykiatrisk slutenvård

Kostnadsandel för patienter med schizofreni eller schizofreniliknande tillstånd i psykiatrisk öppenvård

Kostnadsandel för patienter med schizofreni eller schizofreniliknande tillstånd i psykiatrisk slutenvård

Kostnad per person som fått familjeintervention

Kostnad per person som fått integrerad psykologisk terapi

Kostnad per person som fått arbetslivsinriktad rehabilitering enligt IPS-modellen

Kostnad per person som fått samordnade vård- och stödinsatser enligt ACT-modellen

Kostnad per patient som fått utbildning tillsammans med anhörig

Kostnad per person som fått individuell KBT

Kostnad per person som deltagit i dagverksamhet

Kostnad per person som fått hjälp till bostad, långsiktig boendelösning utan krav på behandlingsföljsamhet eller annan meritering

Generiska

Strukturerad självmordsriskbedömning

\section{Referencer}

1. Bekendtgørelse nr. 1729 af 2. december 2010 om anvendelse af tvang i psykiatrien (psykiatriloven).

2. Psykiatrian erikoisalan laitoshoito 2009 - Institutionsvård inom specialiteten psykiatri 2009. Statistikrapport 4/2011.Finlands officiella statistik, Hälsa 2011. THL

3. Anordning nr. 185 af 13.3.2009 (psykiatriloven)

4. Lov om sindssyge personers hospitalsophold lov nr. 118 af 13. april 1938 med senere ændringer gældende for Grønland. Der er i 1986 lavet en sammenskrivning af loven med dens ændringer, jfr. lov nr. 11150 af 31. oktober 1986

5. Cirkulære nr. 10 om frihedsberøvelse ved indlæggelse, ophold og behandling på Dronning Ingrids Hospitals psykiatriske afdeling

6. Samdata analyse IS-1861. Bruk av tvang i psykisk helsevern for voksne i 2009, Helsedirektoratet, Norge 
7. Bremnes R, Jensberg H.: Kontroll av rapporterte institusjons-og pasientdata om tvangsbruk, vedtak om skjerming og tvangsbehandling. SINTEF Helsetjenesteforskning 2009. SINTEF A11381.

8. Bremnes R, Hatling T, Bjørngaard JH.: Bruk av tvangsmidler i psykisk helsevern $i$ 2001, 2003, 2005 og 2007. Trondheim: SINTEF Helse; 2008.

9. ECT-behandling 2011. Vejledning, Dansk Psykiatrisk Selskab

10. Heshe J, Röder E.: Electroconvulsive therapy in Denmark. Br J Psychiatry 1976;128: 241245.

11. Hedemand E, Christensen P.: Elektrostimulationsbehandling i Danmark. Ugeskr. Læger 1982; 144: 2339-2341.

12. Strömgren LS. Unilateral versus bilateral electroconvulsive therapy. Investigations into the therapeutic effect in endogenous depression. Acta Psychiatr Scand 1973 (Suppl 240): 8-65.

13. Schröder P, Christensen P.: ECT i Danmark. Personal Communication. Præsenteret ved DPS's årsmøde, 1995.

14. Ritschkoff J, Vataja R. Miksi: psykiatri ei hoida leiviskäänsä? Sähköhoitoa ei saa unohtaa. Duodecim 2009;125:480-1

15. Honkonen TI, Aro TA, Isometsä ET, Virtanen EM, Katila HO. Quality of treatment and disability compensation in depression: comparison of 2 nationally representative samples with a 10-year interval in Finland. J Clin Psychiatry 2007;68(12):1886-93.

16. Psykiaterföreningen i Finland. Depressio. Käypä hoito-suositus. 2010. Tillgänglig: http://www.terveysportti.fi/xmedia/hoi/hoi50023.pdf

17. Patienterne og deres forældre har ordet. Undersøgelse i de børne- og ungdomspsykiatriske dag- og døgnafsnit i Danmark 2007-08, Center for Kvalitetsudvikling, marts 2009.

18. Patienterne og de pårørende har ordet. Undersøgelse på de psykiatriske sengeafsnit i Danmark 2009, Center for Kvalitetsudvikling, februar 2010.

19. Patienterne og de pårørende har ordet. Undersøgelse i distriktspsykiatrien i Danmark 2007-08, Center for Kvalitetsudvikling, september 2008

20. Sainio S, Räikkönen O: Asiakastyytyväisyys palveluihin. Teoksessa: Pekurinen M, Räikkönen 0, Leinonen T: Tilannekatsaus sosiaali- ja terveydenhuollon laatuun. Stakesin raportteja 38: 2008.

21. Teräväinen R, Rönnberg K: Tyytyväisyys sosiaali- ja terveyspalveluihin väestökyselyiden ja viranomaiskäsittelyiden perusteella. Teoksessa: Pekurinen M, Räikkönen O, Leinonen T: Tilannekatsaus sosiaali- ja terveydenhuollon laatuun. Stakesin raportteja 38: 2008.

22. Juha Moring, Anne Martins, Airi Partanen, Viveca Bergman, Esa Nordling, Veijo Nevalainen (red.).: Kansallinen mielenterveys- ja päihdesuunnitelma 2009-2015. Toimeenpanosta käytäntöön vuonna 2010. [Nationell plan för psykisk hälsa och missbruksarbete 2009-2015: Det praktiska verkställandet år 2010] Institutet för hälsa och välfärd (THL). Rapport 6/2011. 185 sidor. Helsingfors, Finland 2011. 



\section{Kapitel}

\subsection{Diskussion}

Der er internationalt gennemført en række projekter med henblik på at udvikle kvalitetsindikatorer til belysning af kvaliteten af sundhedsvæsenets ydelser i psykiatrien i regi af bla. OECD, WHO (1-3). OECD har således gennemført to projekter. Konklusionen herpå var, at der kan identificeres kvalitetsindikatorer, men at det ikke var muligt for OECDlandene at tilvejebringe data, der muliggør sammenligning og benchmarking mellem landene. Dette skyldes, at de fleste lande ikke havde sundhedsregistre med data til belysning af de pågældende kvalitetsindikatorer og ikke kan tilvejebringe data på individniveau, dvs i relation til enkelte patienter. Herved er det ikke muligt for landene at kombinere data fra forskellige datakilder, herunder registre.

I konsekvens heraf besluttede OECD, at de eneste kvalitetsindikatorer, der kan indgå i OECDs Health Care Quality Indicator Project er: Ikke planlagt genindlæggelse for patienter med skizofreni og bipolar lidelse, som ligeledes indgår i denne rapport. I forbindelse med OECD-arbejdet har de nordiske lande anført, at disse indikatorer ikke kan belyse kvaliteten af sundhedsvæsenets ydelser i psykiatrien.

I et aktuelt internationalt projekt, som ikke gennemføres i regi af nationale sundhedsmyndigheder, er der på ny identificeret flere hundrede kvalitetsindikatorer, men konklusionen er, at der ikke kan tilvejebringes data med henblik på international sammenligninger (3).

Projektgruppen i Nordisk Ministerråds projekt vedrørende kvalitetsmåling besluttede i forlængelse af disse erfaringer at fokusere på at identificere kvalitetsindikatorer, som blev anvendt i de respektive nordiske lande på grundlag af konkrete data. Formålet hermed har været at skabe grundlag for inspiration landene imellem med henblik på at implementere kvalitetsindikatorer samt at give landene mulighed for at indsamle data til sammenligning og benchmarking mellem de nordiske lande.

Denne rapport giver således et samlet overblik over kvalitetsindikatorer, som er i anvendelse i sundhedsvæsenet i de nordiske lande. I rapporten er ligeledes inddraget kvalitetsindikatorer, som er under implementering, eller hvor der er taget beslutning om implementering.

Samlet set er listen af kvalitetsindikatorer, der anvendes i psykiatrien i de nordiske lande, set i internationalt perspektiv imponerende. Det fremgår af denne rapport, at kvalitetsindikatorerne belyser aspekter af den sundhedsfaglige, den organisatoriske og den patientoplevede kvalitet samt for Danmarks vedkommende også kvaliteten oplevet af pårørende. 
Det fremgår ligeledes af rapporten, at der anvendes kvalitetsindikatorer i de nordiske lande, der belyser sundhedsvæsenets struktur og organisation, selve patientforløbet samt i et vist omfang resultatet af sundhedsvæsenets ydelser.

Dette bekræfter, at de nordiske lande har enestående muligheder for at udvikle og anvende kvalitetsindikatorer. Dette skyldes, at de nordiske lande har velfungerende sundhedsregistre, samt har mulighed for at indsamle data på individniveau, fordi patienterne kan identificeres på grundlag af personnumre.

Rapporten viser imidlertid også, at det er relativt få kvalitetsindikatorer, der kan anvendes umiddelbart til sammenligning og benchmarking mellem de nordiske lande. Dette skyldes dels, at alle lande ikke anvender de samme kvalitetsindikatorer, og dels at der i de nordiske lande anvendes forskellige måder at opgøre resultaterne på.

Dette betyder, at der er behov for en struktureret indsats med henblik på at tilvejebringe sammenlignelige data, herunder identiske datadefinitioner og opgørelsesmåder, såfremt der skal kunne foretages sammenligning og benchmarking i psykiatrien mellem de nordiske lande.

Denne opgave vurderes imidlertid at være overkommelig, og det fremgår af rapporten, at der er et betydeligt grundlag for, at de nordiske lande lader sig inspirere af hinanden, og i øget omfang implementerer kvalitetsindikatorer, der allerede er i anvendelse i andre nordiske lande.

Det er velkendt, at psykiatrien står overfor store udfordringer i de kommende år. De psykiatriske patienters overlevelse er signifikant dårligere end normalbefolkningens, ligesom de psykiatriske patienters dødelighed er højere. Det er ligeledes velkendt, at de psykiatriske patienter har alvorlige livsstilsproblemer sammenlignet med normalbefolkningen, ligesom der er dokumentation for, at psykiatriske patienter ikke i tilstrækkeligt omfang modtager diagnostik, behandling og pleje i overensstemmelse med nationale, kliniske retningslinjer. Disse udfordringer kan kun modsvares, såfremt der iværksættes konkrete nationale initiativer. Monitorering af disse problemstillinger kræver specifikke kvalitetsindikatorer. I rapporten er der angivet konkrete eksempler på kvalitetsindikatorer, der kan anvendes til monitorering af disse problemstillinger.

Det fremgår ligeledes af rapporten, at måling af den patientoplevede kvalitet blandt de psykiatriske patienter er højt prioriteret i de fleste nordiske lande, idet der gennemføres nationale patienttilfredshedsundersøgelser til belysning heraf. Dette er i international sammenhæng enestående, da de fleste OECD lande ikke gennemfører nationale undersøgelser på dette område. Rapporten viser imidlertid også, at resultaterne ikke umiddelbart kan sammenlignes, da der i undersøgelserne er valgt forskellige spørgsmål.

Rapporten viser også, at selv om intentionerne er gode, er der behov for at sikre bla. højere svarprocenter, således at det sikres, at resultaterne er repræsentative for hele gruppen af psykiatriske patienter. 


\section{Referencer}

1. Hermann RC, Mattke S, Somekh D, Silfverhielm H, Goldner E, Glover G, Pirkis J, Mainz J, Chan JA. Int J Qual Health Care. 2006 Sep;18 Suppl 1:31-8.

2. OECD Health Care Quality Indicator Project. www.OECD.com

3. Watkins K, Horvitz-Lennon M, Caldarone LB, Shugarman LR, Smith B, Mannle TE, Kivlahan DR, Pincus HA. J Healthc Qual. 2011 Jan-Feb;33(1):49-66 



\section{Kapitel}

\subsection{Konklusion og anbefalinger}

Denne rapport dokumenterer, at der i de nordiske lande er et stort potentiale for måling og monitorering af kvaliteten af sundhedsvæsenets ydelser indenfor psykiatrien. Internationalt er dette område svagt belyst. I international sammenhæng er de nordiske lande således blandt de lande, der er nået længst med national kvalitetsmåling. Dette skyldes, at kvalitetsudvikling i de nordiske lande er højt prioriteret, samt at de nordiske lande har unikke muligheder for kvalitetsmåling indenfor psykiatrien, dels fordi der er etableret velfungerende sundhedsregistre, og dels fordi det er muligt at indsamle data relateret til den enkelte patient.

Der er således næppe tvivl om, at de nordiske lande kan bidrage i betydeligt omfang til inspiration og samarbejde om kvalitetsmåling på grundlag af kvalitetsindikatorer indenfor psykiatrien på internationalt niveau. På baggrund af rapporten kan det anbefales:

- At de nordiske lande fortsætter et tæt samarbejde om videreudvikling af kvalitetsindikatorer til belysning af kvaliteten af sundhedsvæsenets ydelser i psykiatrien med henblik på offentliggørelse af resultater, sammenligning og benchmarking.

Det vil være op til sundhedsmyndighederne i de nordiske lande at tage stilling til det fremtidige samarbejde om kvalitetsmåling i psykiatrien. 



\section{Summary}

The Nordic Council of Ministers initiated the Nordic Project on Measuring the Quality of Health Services in 2007. This included four subprojects that aimed to develop and describe Nordic quality indicators during the project period 2007-2010:

1. generic and disease-specific quality indicators

2. quality indicators for oral health services

3. indicators of patient safety

4. indicators of patient-rated quality

The Nordic Council of Ministers published the results of the project in a report (in Danish) on the four projects: Nordisk kvalitetsmåling $i$ sundhedsvæsenet [Measuring quality in the health services in the Nordic countries].

During the project period, it was decided to describe Nordic indicators of the quality of mental health services in a separate report to be prepared from September 2010 to June 2011. This report is the result.

The overall purpose is to give Nordic citizens, politicians, health care personnel and health authorities the opportunity to assess and compare health services across the national borders in the Nordic countries and to identify areas in which the Nordic countries can learn from one another with the aim of improving the quality of health services for the people in focus: patients.

The project group was asked to prepare proposals for indicators that could comprise the basis for registering and monitoring the quality of mental health services in the Nordic countries.

The project group decided to include all indicators of quality that are used to indicate the quality of mental health services in the Nordic countries in relation to hospital treatment and potential indicators that are expected to be implemented in the Nordic countries in the near future within the following areas:

- generic indicators of the quality of mental health services

- compulsory measures

- electroconvulsive therapy

- schizophrenia among adults and among children and adolescents

- moderate and severe depression being treated in hospitals

- bipolar disorder

- attention deficit hyperactivity disorder

- quality as rated by patients and their family members 
The report thus presents all the quality indicators used in the respective Nordic countries within these areas of mental health services provided in secondary health care: inpatient treatment and associated outpatient treatment. The report further presents specific examples of how quality is measured using the indicators in the respective countries to illustrate how these indicators are used to develop the quality of mental health services in the Nordic countries.

The report shows that data can be generated in some areas that enable comparison between the Nordic countries, whereas few data are available in other areas. This means that Nordic indicators still need to be developed in several areas. The report also shows that considerable effort is needed to improve the quality of data. This means that many results are probably not correct because data are calculated differently in the individual Nordic countries and because few data are available in certain areas.

The report shows that the Nordic countries have great potential to measure and monitor the quality of mental health services. This field has been inadequately investigated internationally. The Nordic countries are thus among the countries that have achieved the most in national measurement of the quality of mental health services. The reason is that the Nordic countries place high priority on developing quality and that the Nordic countries have unique opportunities to measure the quality of mental health services because of well-established health-related registries and because data can be collected that are linked to individual patients.

Thus, the Nordic countries can certainly contribute substantially to inspiring and collaborating on the international measurement of the quality of mental health services based on quality indicators. 


\section{Tiivistelmä}

Pohjoismaiden ministerineuvosto käynnisti vuonna 2007 projektin pohjoismaalaisen terveydenhuollon laadun mittauksesta. Se koostui neljästä osahankkeesta, joiden tarkoitus oli projektin aikana vuosina 2007-2010 kehittää ja kuvata yhteispohjoismaisia:

1. Yleisiä ja sairauskohtaisia laatuosoittimia

2. Laatuosoittimia suu- ja hammasterveydelle

3. Potilasturvallisuusosoittimia

4. Laatuosoittimia potilaiden kokemalle laadulle

Projektin tulokset julkaistiin 2010 yhteisessä raportissa, jossa oli mukana tulokset neljästä alaprojektista otsikolla Nordisk kvalitetsmåling i sundhedsvæsenet (Pohjoismaalainen terveydenhuollon laadun mittaus) TemaNord 2010:572 (1).

Projektin aikana päätettiin, että psykiatrian yhteispohjoismaiset laatuosoittimet pitäisi kuvata erillisessä raportissa syyskuun 2010 ja heinäkuun 2011 välisenä aikana. Tämä raportti on sen lopputulos.

Päällimmäisenä tarkoituksena on antaa Pohjoismaiden asukkaille, päättäjille, terveydenhuollon henkilökunnalle ja terveydenhuollon viranomaisille mahdollisuus arvioida ja verrata terveydenhuollon palveluita yli pohjoismaisten rajojen, ja samalla tunnistaa alueita, joissa Pohjoismaat voivat ottaa toisistaan oppia parantaakseen terveydenhuoltopalveluita potilaille, joista asiassa todella on kyse.

Projektiryhmän tarkoitus oli työstää ehdotuksia indikaattoreille, jotka luovat pohjan psykiatrian terveydenhuollon palveluiden rekisteröinnille ja seurannalle Pohjoismaissa.

Projektiryhmä päätti sisällyttää kaikki laatuosoittimet, joita käytetään valottamaan terveydenhuollonpalveluiden laatua pohjoismaalaisessa terveydenhuollossa koskien sairaalahoitoa, kuin myös mahdolliset indikaattorit, jotka on otetaan käyttöön Pohjoismaissa lähitulevaisuudessa koskien seuraavia osa-alueita:

- Yleiset psykiatriset indikaattorit

- Pakkokeinot

- Sähköhoito

- Skitsofrenia, aikuiset sekä lapset ja nuoret

- Masennus (keskivaikea ja vaikea masennus sairaalaolosuhteissa)

- Kaksisuuntainen mielialahäiriö

- Tarkkaavaisuus- ja ylivilkkaushäiriö eli ADHD (Attention Deficit/Hyperactivity Disorder) 
- Potilaiden ja omaisten kokema laatu

Raportti esittää siis kaikki laatuosoittimet, joita käytetään kussakin Pohjoismaassa näillä psykiatrian alueilla liittyen potilaiden hoitoon sairaalaja avohoidossa. Raportti esittää lisäksi konkreettisia esimerkkejä laatumittauksista indikaattorien pohjalta kussakin maassa kuvaamaan indikaattorimittauksien käyttöä psykiatrisen hoidon laadun kehittämiseksi Pohjoismaissa.

Raportti osoittaa, että tietyillä avainalueilla on saatavilla tietoja, jotka mahdollistavat vertailun Pohjoismaiden kesken, kun taas muilla alueilla tietoa on saatavilla vain rajallisesti. Tämä tarkoittaa sitä, että monilla alueilla on edelleenkin tarve kehittää yhteispohjoismaisia osoittimia. Raportin mukaan myös tiedon laadun takaamiseksi on tehtävä merkittäviä ponnistuksia. Tämä tarkoittaa sitä, että monet tulokset tuskin kertovat totuutta, koska tietoa kerätään Pohjoismaissa eri tavoin ja koska tiettyjen alueiden tietoa on saatavilla vain rajallisesti.

Raportti osoittaa, että Pohjoismaista löytyy paljon potentiaalia mitata ja valvoa psykiatrisen terveydenhuollon palveluiden laatua. Kansainvälisesti tämä alue on huonosti tunnettu. Kansainvälisesti Pohjoismaat ovat siis niiden maiden joukossa, jotka ovat pisimmällä kansallisessa laadunmittauksessa. Tämän vuoksi laadunkehitys Pohjoismaissa on priorisoitu korkealle ja Pohjoismaissa on ainutlaatuisia mahdollisuuksia psykiatrian laadunmittaukselle, koska maissa on olemassa hyvin toimivia terveydenhuollon rekistereitä ja koska maissa on mahdollisuus kerätä tietoja yksittäisistä potilaista.

Tuskin on siis epäilystä siitä, että Pohjoismaat voivat merkittävästi myötävaikuttaa laadunmittauksen kiinnostukseen ja yhteistyöhön psykiatrian laatuindikaattoreiden pohjalta kansainvälisellä tasolla. 


\section{Samandráttur}

Norðurlendska ráðharraráðið setti í 2007 í verk verkætlanina:

Norðurlendsk dygdarmeting í heilsuverkinum, ið fevndi um fýra partsverkætlanir, hvørs endamál vóru í verkætlanartíðarskeiðinum at menna og lýsa felags norðurlendskar:

1. Heildar- og sjúkuserkendar dygdarábendingar

2. Dygdarábendingar fyri munn- og tannheilsu

3. Sjúklingatrygdarábendingar

4. Dygdarábendingar fyri sjúklinganøgdsemi

Úrslitini frá verkætlanini komu í 2010 í eini felags frágreiðing við úrslitum frá teimum fýra verkætlanunum við heitinum: Nordisk kvalitetsmåling i sundhedsvæsenet TemaNord 2010:572 (1).

Í verkætlanartíðarskeiðnum varð avgjørt, at felags norðurlendskar dygdarábendingar fyri sálarliga heilsu skuldu lýsast í eini serligari frágreiðing í tíðarbilinum frá september 2010 til juli 2011. Hendan frágreiðing er úrslitið av hesi viðgerð.

Yvirskipaða endamálið er at veita norðurlendskum borgarum, politikarum, heilsustarvsfólki og heilsumyndugleikum møguleikan at meta um og bera saman veitingarnar í heilsuverkinum tvørtur um norðurlendsk landamørk, umframt at eyðmerkja øki, har ið Norðurlond kunnu læra hvørt av øðrum við tí endamáli at bøta um veitingardygd heilsuverksins fyri tey, ið alt snýr seg um, nevnliga sjúklingarnar.

Verkætlanarbólkurin skuldi gera uppskot til ábendingar, sum kunnu gerast grundarlag undir skráseting og monitorering av dygdini í veitingum heilsuverksins í Norðurlondum innan sálarsjúkufrøði.

Verkætlanarbólkurin gjørdi av at taka við allar dygdaábendingar, ið verða nýttar til tess at lýsa dygdina í veitingum heilsuverksins í norðurlendsku heilsuverkunum, tá ið hugsað verður um sjúkrahúsviðgerð, umframt møguligar ábendingar, ið væntast kunnu at verða settar í verk í Norðurlondum í næstu framtíð á hesum økjum:

- Heildarábendingar innan sálarliga heilsu

- Tvingsilsatgerðir ECT (Electro Convulsive Therapy)

- Sinniskloyving (Skizofreni), vaksin, børn og ung

- Tunglyndi (hóvsamt til miðaltungt tunglyndi í sjúkrahúsviðgerð)

- Bipolar (Tvípólað) sjúka

- ADHD (Attention Deficit/Hyperactivity Disorder)

- Dygd, ið sjúklingar og avvarðandi hava upplivað 
Í frágreiðingini verða sostatt lýstar allar dygdarábendingar, ið nýttar verða í ymsu Norðurlondunum innan hesi øki í sálarsjúkufrøðini, tá hugsað verður um viðgerð av sjúklingum í sjúkrahúsviðgerð og útistovuviðgerð í sambandi við hesa. Í frágreiðingini verða harumframt víst ítøkilig dømi um dygdarmátingar við støði í ábendingum í ymisku londunum til tess at lýsa nýtsluna av ábendingarmátingum fyri dygdarmenning innan sjálarsjúkufrøði í Norðurlondum.

Frágreiðingin sýnir, at á nøkrum økjum ber til at fáa til vega dáta, so til ber at samanbera tvørtur um norðurlendsk landamørk, meðan tað á øðrum økjum bert eru tøk dáta í minni mun. Hetta ber í sær, at tað framvegis á fleiri økjum er tørvur á at menna felags norðurlendskar ábendingar. Frágreiðingin lýsir somuleiðis tørvin á munandi virksemi til tess at tryggja dygdina á dátum. Hetta ber í sær, at ein røð av úrslitum neyvan eru eftirfarandi, lutvíst tí at dáta verða gjørd upp so ymiskt í Norðurlondum, og lutvíst av tí at dáta innan ávís øki bert eru til taks í avmarkaðari nøgd.

Frágreiðingin skjalprógvar, at í Norðurlondum eru stórir møguleikar at máta og monitorera veitingardygd heilsuverksins innan sálarsjúkufrøði. Í alheimshøpi er hetta økið ikki væl lýst. Norðurlond eru tí millum teirra, sum eru komin longst, tá ið dygd verður mátað. Orsøkin til hetta er, at dygdarmenning í Norðurlondum verður raðfest høgt, umframt at Norðurlond hava eindømismøguleikar fyri dygdarmáting í sálarsjúkufrøðini, lutvíst av tí at vælvirkandi heilsuskráir eru skipaðar, og lutvíst tí at til ber at fáa til vega dáta fyri einstaka sjúklingin.

Sostatt er neyvan ivi um, at Norðurlond í stóran mun kunnu geva íkast til íblástur og samstarv um dygdarmeting grundað á dygdarábendingar innan sálarsjúkufrøðina á alheimsstøði. 


\section{Inussiarnersumik Inuulluaqqusillunga}

Nunani Avannarlerni Siunnersuisoqatigiit 2007-imi suliniut aallarnigaat: Nunat Avannarliit peqqinnissaqarfiini sullissinerup pitsaassusaanik ersersitsisussamik naliliineq sisamanik immikkoortortaqartoq, ataatsimoorussanillu nunani avannarlerni piffissap suliniuteqarfiup 2007-imiit 2010mut ingerlanerani makkunuuna ineriartortitsinissamik nalunaarusiornissamillu siunertalik pilersinneqarpoq:

- Pissutsinut nalinginnaasunut nappaatinullu aalajangersimasunut tunngatillugit pitsaassutsimik naliliinermi uuttuutissat

- Qarnup kigutillu paarinissaannut pitsaassutsimik naliliinermi uuttuutissat

- Isumannaatsumik napparsimasut sullinneqarnissaat pillugu pitsaassutsimik naliliinermi uuttuutissat

- Napparsimasut misigisaat tunngavigalugit sullinneqarnerup pitsaassusaanik naliliinermi uuttuutissat

Suliniutini sisamaasuni angusat 2010-mi ataatsimut nalunaarummi saqqummiunneqarput ima atsikkamik: Nunat Avannarliit peqqinnissaqarfiini sullissinerup pitsaassusaanik naliliineq TemaNord 2010:572 (1).

Tarnimikkut nappaatilinnik nakorsaanermut tunngatillugu pitsaassutsimik naliliinissami uuttuutissat nunanut avannarlernut tamanut atuuttussat, 2010-mi septemberimiit 2011-mi juulip tungaanut immikkut nalunaarusiornermi allaasserineqarnissaat suliniuteqarnerup nalaani aalajangiunneqarpoq. Aalajangernerullu tamatuma kinguneranik matuminnga nalunaarusiortoqarpoq.

Peqqinnissaqarfimmit sullinneqarnerup Nunat Avannarliit killeqarfii akimorlugit kiisalu pissutsit assersuullugillu naliliivigisinnaanissaannut, Nunani Avannarlerni innuttaasut, politikerit, peqqinnissamik sullissisut, peqqinnissaqarfimmullu oqartussaasut periarfissinnissaat anguniakkat pingaarnersaraat. Nunani Avannarlerni peqqinnissakkut sullissinermi qitiullutik inissisimasut, tassalu napparsimasut, sullinnerisa pitsaanerulersinnissaa anguniarlugu, ilinniarfigeqatigiissinnaanerup periarfissinnissaa siunniussattaaq ilagaat.

Tarnikkut nappaatilinnik nakorsaanermut atatillugu, nalunaarsuinermi nakkutilliinermilu Nunat Avannarliit peqqinnissaqarfiisa atorsinnaasaannik, pitsaassutsimik naliliiniarnermi uuttuutitut toqqammavissanik, suliniuteqaqatigiit siunnersuusiortinneqarput. 
Nunani Avannarlerni peqqinnissaqarfinnit sullissinerup napparsimmavinni nakorsartinnermut tunngasortaata pitsaassusaanik ersersitsiniarnermi uuttuutit tamaasa ilanngunniarlugit, kiisalu Nunani Avannarlerni pitsaassutsimik naliliinermi uuttuutigineqarsinnaasut piaartumik atuutsilerneqarumaartussatut makku suliniuteqaqatigiinnit aalajangerneqarput:

- Tarnikkut nappaatinut tunngatillugu sullissinermi pitsaassutsimut uuttuutit

- Pinngitsaaliilluni iliuuseqartarneq

- Qarasaq qupinnguallatsillugu nakorsaaneq (Electro Convulsive Therapy)

- Skizofreni, inersimasuni, meeqqani inuusuttunilu

- Nikallunganeq (napparsimavimmi uninngassutaasumik akunnattumik sakkortuumillu nikallunganeq)

- Nikallungalersarlunilu aallaamalersarneq

- ADHD (Attention Deficit/Hyperactivity Disorder)

- Napparsimasut ilaqutaasullu sullinneqarnerup pitsaassusaanik misigisaat

Nunani Avannarlerni ataasiakkaani, peqqinnissaqarfimmi sullissinermut atatillugu, pitsaassutsimut uuttuutaasunut qulaani pineqartunut, napparsimasut napparsimmavinni nakorsarneqartarnerannut, unitsinnagillu nakorsaasarnernut tunngasut, nalunaarummi saqqummiunneqarput. Nunani pineqartuni pitsaassutsimik naliliinermi uuttuutigineqartartut, pitsaassutsimik uuttuinerit tigussaasut assersuutitut tunngavigalugit pitsaassutsimik naliliinermi uuttuinerup, nunani avannarlerni tarnikkut nappaatilinnik nakorsaanermi atorneqarsinnaanera, nalunaarummi saqqummiunneqarportaaq.

Nalunaarut naapertorlugu immikkoortut ilaanni nunat avannarliit akornanni assersuussinermi paasissutissanik atorneqarsinnaasunik pissarsisoqarsinnaavoq, allatigulli paasissutissat pissarsiarineqarsinnaasut killeqarput. Taamaammat suli immikkoortuni arlalinni ataatsimoorussanik pitsaassutsimik naliliinermi uuttuutissanik ineriartortitsinissaq pisariaqartinneqarpoq. Paasissutissat pitsaassusaasa qulakkeerneqarnissaannik pisariaqartisinerup annertuumik suliniute qarfiginissaa nalunaarummi ersersinneqarportaaq. Paasissutissat naliliivigineqartarnerat Nunani Avannarlerni assigiinngimmat, immikkoortullu ilaanni paasissutissat killeqarmata, paasisat ilaat tamatuma kinguneranik eqqoqqissaartuusinnaanngillat.

Tarnimikkut nappaatillit nakorsarneqarnerat pillugu, pitsaasutsimik naliliinissamut nakkutilliinissamullu Nunani Avannarlerni annertuumik periarfissaqartoq, nalunaarummi uppernarsineqarpoq. Immikkoortoq taanna nunarsuaq tamakkerlugu annikitsuinnarmik paasissutissartaqarpoq. Nunarsuarmioqatigiit akornanni Nunat Avannarliit naalagaaffittut, pitsaassutsimik naliliinermut tunngatillugu nunanut siuarsimanerpaanut ilaapput. Pitsaassutsimik ineriartortitsinerup suliassanik 
tulleriiaarinerni pingaarnerit ilaattut Nunani Avannarlerni inissisimanera, kiisalu Nunani Avannarlerni tarnimikkut nappaatillit nakorsarneqarnerannut tunngatillugu pitsaassutsimik naliliinissamut asseqanngitsumik periarfissagissaarnera, peqqinnissamut tunngatillugu nalunaarsuivinnik pitsaasunik pilersitsisoqarsimanera, napparsimasullu ataasiakkaat pillugit paasissutissanik katersisinnaaneq tamatumunnga pissutaavoq.

Taamaammat nunarsuaq tamakkerlugu tarnimikkut nappaatillit sullinneqarneranni pitsaassutsip naliliivigineqarnerani uuttuutinut tunngatillugu, Nunat Avannarliit isumassarsiviullutillu suleqataasinnaanermikkut annertuumik tunniussaqarsinnaanerat qularnanngilaq. 



\section{Samantekt}

Árið 2007 hóf Norræna ráðherraráðið verkefnið: Norrænar gæðamælingar í heilbrigðiskerfinu.Verkefnið tók til fjögurra hlutaverkefna á tímabilinu 2007-2010 og var markmiðið að próa og lýsa samnorrænum gæðavísum á eftirfarandi sviðum:

1. Almennir og sjúkdómatengdir gæðavísar

2. Gæðavísar fyrir munn- og tannheilsu

3. Gæðavísar fyrir öryggi sjúklinga

4. Gæðavísar um reynslu sjúklinga af gæðum heilbrigðispjónustunnar

Niðurstöður verkefnisins voru birtar árið 2010 í sameiginlegri skýrslu undir heitinu: Nordisk kvalitetsmåling i sundhedsvæsenet TemaNord 2010:572 (1).

Á verkefnistímanum var ákveðið að samnorrænum gæðavísum í geðheilbrigðispjónustu yrði gerð skil í sérstakri skýrslu sem unnin væri á á tímabilinu september 2010 til júlí 2011. Niðurstöðum vinnunnar er lýst í pessari skýrslu.

Aðalmarkmiðið er að gefa norrænum borgurum, stjórnmálamönnum, heilbrigðisstarfsmönnum og heilbrigðisyfirvöldum tækifæri til að meta og bera saman heilbrigðispjónustu á öllum Norðurlöndunum. Annað markmið er að skilgreina svið par sem Norðurlandapjóðirnar geta lært hver af annarri með pað fyrir augum að auka gæði peirrar heilbrigðispjónustu sem sjúklingar fá, pví allt snýst petta um pá.

Starfshópur verkefnisisns átti að vinna tillögur að vísum sem gæu verið grunnur að skráningu og mati á gæðum heilbrigðispjónustunnar á Norðurlöndunum innan geðheilbrigðispjónustunnar.

Starfshópurinn ákvað að taka saman alla gæðavísa sem notaðir eru til að lýsa gæðum heilbrigðispjónustunnar á Norðurlönunum hvað varðar meðferð á sjúkrahúsum. Einnig að lýsa mögulegum gæðavísum sem Norðurlöndin gætu nýtt í nánustu framtíð á eftirfarandi sviðum:

- Almennir gæðavísar í geðheilbrigðispjónustu

- Pvingunarúrræði

- Raflækningar (ECT, Electro Convulsive Therapy)

- Geðklofi, fullorðnir, ásamt börnum og ungmennum

- Punglyndi (vægt og alvarlegt punglyndi í sjúkrahúspjónustu)

- Geðhvarfasýki

- ADHD (Attention Deficit/Hyperactivity Disorder. Athyglisbrestur/Ofvirkni)

- Gæðavísar um reynslu sjúklinga af heilbrigðispjónustu 
Í skýrslunni er gerð grein fyrir öllum gæðavísum sem notaðir eru á Norðurlöndunum á pessum sviðum í geðheilbrigðispjónustu hvað varðar meðferð sjúklinga í annars stigs pjónustu, p.e.a.s. meðferð á sjúkrahúsum og göngudeildarbjónustu henni tengdri. Skýrslan lýsir einnig raunverulegum dæmum á grunni gæðavísa frá einstaka löndum til að lýsa notkun peirra við gæðapróun innan geðheilbrigðispjónustu.

Skýrslan sýnir að hægt er á nokkrum sviðum að koma fram með tölur sem gerir samanburð milli landa mögulegan en á öðrum sviðum eru tölur ekki tiltæknar nema í litlum mæli. Pví parf á peim sviðum að vinna frekari próunarvinnu að sambærilegum gæðavísum milli landnanna. Skýrslan sýnir ennfremur að nauðsynlegt er að leggja aukinn kraft í að tryggja áreiðanleika tölfræðilegra upplýsinga. petta felur í sér að ákveðinn hluti niðurstaðna gefur ekki rétta mynd. Annars vegar vegna pess að tölfræðigögnin eru ekki unnin með sama hætti í löndunum og hins vegar að víða skortir á upplýsingar í löndunum.

Skýrslan sýnir að pað eru miklir möguleikar til að mæla og fylgjast með gæðum heilbrigðispjónustunnar í löndununm á geðheilbrigðissviði. Í alpjóðlegu samhengi er petta svið ekki vel sýnilegt. Í alpjóðlegum samhengi má segja að Norðurlöndin hafi náð einna lengst í mati á gæðum pjónustunnar. Skýringin er sú að gæðapróun í heilbrigðispjónustu er sett í forgang og að Norðurlöndin hafa einstakt tækifæri til að fylgjast með gæðum pjónustunnar á sviði geðheilbrigðismála. Að hluta til er pað vegna góðra gagnagrunna og hins vegar vegna pess að hægt er að safna upplýsingum sem tengjast einstökum sjúklingum.

Pað er pví varla hægt að efast um að Norðurlöndin hafi margt fram að færa til að hvetja til og vinna að mati á gæðum á grundvelli gæðavísa á sviði geðheilbrigðispjónustu á alpjóðavísu. 


\section{Bilag 1: Repræsentanter i styregruppen for nordisk kvalitetsmåling}

\section{Danmark}

Jan Mainz, professor, ledende overlæge, Ph.D Sundhedsstyrelsen, OECD repræsentant (formand)

Jytte Burgaard, sygeplejerske, konsulent, Sundhedsstyrelsen (sekretariat)

\section{Finland}

Anne Nordblad, medicinalråd, Social- och hälsovårdsministeriet

Mika Gissler, forskningsprofessor THL Institutet för hälsa och välfärd

\section{Færøerne}

Høgni Debes Joensen, landslæge, Sundhedsministeriet

\section{Grønland}

Karna Jokumsen, sundhedsfaglig konsulent, Departementet for Familie og Sundhed

\section{Island}

Margrét Björnsdóttir, afdelingschef, Sundhedsministeriet, OECD-repræsentant

\section{Norge}

Jan Sigurd Røtnes, avdelingsdirektør, Sosial- og Helsedirektoratet, OECD-repræsentant Geir Bukholm, afdelingsdirektør, Seniorrådgiver Nationalt Kunnskapssenter for Helsetjenesten, OECD-repræsentant Målfrid Monge, suppleant, seniorrådgiver, Sosial- og helsedirektoratet Thorstein Ouren, afdelingsdirektør, Sosial- og helsedirektoratet

\section{Sverige}

Marie Lawrence, enhetschef, Socialstyrelsen, OECD-repræsentant 



\title{
Bilag 2: Oversigt over nationale kvalitetsindikatorer indenfor psykiatri til offentliggørelse i de nordiske lande
}

\author{
Danmark
}

Skizofreni (voksne) ICD-10 kode: F20

Kilde

Generiske procesindikatorer for børn og unge til og med 17 år

Andel af behandlingsforl $\varnothing \mathrm{b}$ med svag belastning ved afslutning eller efter $6 \mathrm{mdr}$.

Andel af behandlingsforløb med god psykosocial funktion ved afslutning eller efter 6 . mdr.

Uplanlagt skizofreni (samme hospital) genindlæggelsesrate

Andelen af incidente patienter med skizofreni, der udredes for psykopatologi ved speciallæge

Andelen af incidente patienter med skizofreni, der udredes for psykopatologi og interviewes med diagnostisk instrument (SAN, PSE, OPCRIT, SCID)

Andelen af incidente patienter med skizofreni, der udredes for kognitiv funktion ved psykolog

Andelen af incidente patienter med skizofreni, der udredes for sociale st $\varnothing$ ttebehov ved socialråd-

giver

Andelen af incidente patienter med skizofreni, der udredes for varighed af ubehandlet psykose og

som er $\mathrm{i}$ behandling indenfor $6 \mathrm{mdr}$. efter symptomdebut

Andelen af ambulante patienter med skizofreni, som har tilknyttet et fast medlem af behandler-

teamet og/eller har fået iværksat et psykoterapeutisk behandlingsforløb

Andelen af ambulante patienter med skizofreni, som får mere end ét antipsykotikun ved årsstatus NIP

Andelen af ambulante patienter med skizofreni, som får benzodiazepiner eksklusiv benzodiazepin- NIP

lignende midler (zolpidem, zopiclon, zaleplon) ved årsstatus

Andelen af patienter med skizofreni, som får ordineret antipsykotisk behandlingNIP

NIP

Andelen af patienter med skizofreni, hvor pårørende tager imod tilbudet om kontakt

NIP

Andelen af incidente patienter med skizofreni, der indenfor 2 år modtager psykoedukation i manualiserede forløb

Andelen af patienter med skizofreni, der indenfor 11/2 år efter udskrivelsen har fået udfyldt et

statusskema for ambulante patienter

Andelen af patienter med skizofreni, med GAF funktionsscore $<30$ ved udskrivelse og som udskri-

ves med social støtteforanstaltning i bolig

Andelen af indlagte patienter med skizofreni, der får vurderet selvmordsrisiko, dokumenteret i

journalen, ved udskrivelsen

Andelen af patienter med skizofreni, der modtager psykiatrisk efterbehandling ved udskrivelsen

Andelen af patienter med skizofreni, som har neurologiske bivirkninger

Andelen af patienter med skizofreni, som har søvn- og sedationsbivirkninger

Andelen af patienter med skizofreni, som har haft vægtøgning

Andelen af patienter med skizofreni, som har seksuelle bivirkninger

Andelen af patienter med skizofreni, som har forhøjet BMI

Andelen af patienter med skizofreni, som har forøget taljeomfang

Andelen af patienter med skizofreni, som har forhøjet blodsukker

Andelen af patienter med skizofreni, som har dyslipidæmi

Andelen af patienter med skizofreni, som har forhøjet blodtryk

Procentdel af patienter med skizofreni, der får unders $\varnothing$ gt selvmordsrisiko

Andel af patienter med skizofreni der i de fem danske regioner har modtaget alle anbefalede

BUP-basen

BUP-basen

OECD

NIP

NIP

NIP

NIP

NIP 
Depression ICD-10 kode: DF32-34.1, F06.32

Antal patienter med depression der har fået behandling med elektroshock ECT i forhold til antal

Børne- og ungdomsskizofreni ICD-10 kode: F20-29

Uplanlagt skizofreni (alle sygehuse) genindlæggelsesrate giver

Andelen af incidente patienter med skizofreni, der udredes for varighed af ubehandlet psykose og NIP som er i behandling indenfor 6 måneder efter symptomdebut

Andelen af ambulante patienter med skizofreni, som har tilknyttet et fast medlem af behandler- NIP teamet og/eller har fået iværksat et psykoterapeutisk behandlingsforl $\emptyset \mathrm{b}$

Andelen af patienter med skizofreni, hvor pårørende tager imod tilbudet om kontakt

Andelen af indlagte patienter med skizofreni, der får vurderet selvmordsrisiko, dokumenteret i NIP journalen, ved udskrivelsen

Andelen af patienter med skizofreni, som får ordineret antipsykotisk behandling

Andelen af patientermed skizofreni, med GAF funktionsscores 30 ved udskrivelse og som udski-

ves med social st $\varnothing$ tteforanstaltning i bolig

Andelen af patienter med skizofreni, der modtager psykiatrisk efterbehandling ved udskrivelsen Andelen af patienter med skizofreni, der indenfor $1 \frac{1}{2}$ år efter udskrivelsen har fået udfyldt et

Andelen af patienter med skizofreni, som har neurologiske bivirkninger

Andelen af patienter med skizofreni, som har $\varsigma \varnothing \mathrm{vn}$ - og sedationsbivirkninger

Andelen af patienter med skizofreni, som har haft vægtøgning

Andelen af patienter med skizofreni, som har seksuelle bivirkninger

Andelen af patienter med skizofreni, som har forhøjet BMI

Andelen af patienter med skizofreni, som har forøget taljeomfang

Andelen af patienter med skizofreni, som har forhøjet blodsukker

Andelen af patienter med skizofreni, som har dyslipidæmi

Andelen af patienter med skizofreni, som har forhøjet blodtryk 
Andel psykiatriske patienter som er i behandling i sekundær sektor pr. 100.000 indbyggere (Samlet)

Andel psykiatriske patienter som er i behandling i sekundær sektor pr. 100.000 indbyggere (Samlet) (aldersgrupper: 15-24)

Andel psykiatriske patienter som er i behandling i sekundær sektor pr. 100.000 indbyggere (Samlet) (aldersgrupper: 25-44)

Andel psykiatriske patienter som er i behandling i sekundær sektor pr. 100.000 indbyggere (Samlet) (aldersgrupper: 45-64)

Andel psykiatriske patienter som er i behandling i sekundær sektor pr. 100.000 indbyggere (Sam-

let) (aldersgrupper: 65-84)

Andel psykiatriske patienter som er i behandling i sekundær sektor pr. 100.000 indbyggere (Sam-

let) (aldersgrupper: $85+$ )

Andel psykiatriske patienter som er i behandling i sekundær sektor pr. 100.000 indbyggere

(Mænd)

Andel psykiatriske patienter som er i behandling i sekundær sektor pr. 100.000 indbyggere

(Mænd) (aldersgrupper: 15-24)

Andel psykiatriske patienter som er i behandling i sekundær sektor pr. 100.000 indbyggere

(Mænd) (aldersgrupper: 25-44)

Andel psykiatriske patienter som er i behandling i sekundær sektor pr. 100.000 indbyggere

(Mænd) (aldersgrupper: 45-64)

Andel psykiatriske patienter som er i behandling i sekundær sektor pr. 100.000 indbyggere

(Mænd) (aldersgrupper: 65-84)

Andel psykiatriske patienter som er i behandling i sekundær sektor pr. 100.000 indbyggere

(Mænd) (aldersgrupper: 85+)

Andel psykiatriske patienter som er i behandling i sekundær sektor pr. 100.000 indbyggere (Kvinder)

Andel psykiatriske patienter som er i behandling i sekundær sektor pr. 100.000 indbyggere (Kvinder) (aldersgrupper: 15-24)

Andel psykiatriske patienter som er i behandling i sekundær sektor pr. 100.000 indbyggere (Kvinder) (aldersgrupper: 25-44)

Andel psykiatriske patienter som er i behandling i sekundær sektor pr. 100.000 indbyggere (Kvinder) (aldersgrupper: 45-64)

Andel psykiatriske patienter som er i behandling i sekundær sektor pr. 100.000 indbyggere (Kvinder) (aldersgrupper: 65-84)

Andel psykiatriske patienter som er i behandling i sekundær sektor pr. 100.000 indbyggere (Kvinder) (aldersgrupper: $85+$ )

Antallet af relevante fagfolk pr. 100.000 indbyggere (psykiatere)

Antallet af relevante fagfolk pr. 100.000 indbyggere (psykiatriske sygeplejersker)

Antallet af relevante fagfolk pr. 100.000 indbyggere (psykologer)

Antallet af relevante fagfolk pr. 100.000 indbyggere (børnepsykiatere)

Antal tvangstilbageholdte personer på psykiatrisk afdeling

Antal personer behandlet med medicin under tvang på psykiatrisk afdeling

Antal personer behandlet med ECT under tvang på psykiatrisk afdeling

Antal personer ernæret under tvang på psykiatrisk afdeling

Antallet af fikseringer og/eller fysisk magtanvendelse på psykiatrisk afdeling i et år

Antal personer der har været berørt af fiksering og/eller fysisk magtanvendelse

Antal personer der har været berørt af beskyttelsesfiksering/foranstaltning

Antallet af beskyttelsesfiksering/foranstaltning i et år

Antallet af psykiatriske senge, pr. 100.000 indbyggere

Udskrivninger (afsluttede indlagte forløb) fra psykiatriske enheder, pr. 1.000 indbyggere

Sengedage pr. 1.000 indbyggere i psykiatriske enheder

Gennemsnitlig liggetid på psykiatriske enheder

Antallet af psykisk syge patienter der er indlagt på sygehus kontinuerligt i mere end 1 år, pr.

100.000 indbyggere

Hospitalsbehandling på psykiatriske enheder (Samlet)

Hospitalsbehandling på psykiatriske enheder (Samlet) (aldersgruppe: 0-14) 
Hospitalsbehandling på psykiatriske enheder (Kvinder) (aldersgruppe: 15-29)

NOMESCO

Hospitalsbehandling på psykiatriske enheder (Kvinder) (aldersgruppe: 30-44)

NOMESCO

Hospitalsbehandling på psykiatriske enheder (Kvinder) (aldersgruppe: 45-64)

NOMESCO

Hospitalsbehandling på psykiatriske enheder (Kvinder) (aldersgruppe: 65-79)

NOMESCO

Hospitalsbehandling på psykiatriske enheder (Kvinder) (aldersgruppe: 80+)

NOMESCO

Behandlede patienter pr. 1.000 indbyggere på psykiatriske enheder (Samlet)

NOMESCO

Behandlede patienter pr. 1.000 indbyggere på psykiatriske enheder (Samlet) (Diagnosegruppe

NOMESCO

(ICD-10): F10-19)

Behandlede patienter pr. 1.000 indbyggere på psykiatriske enheder (Samlet) (Diagnosegruppe (ICD-10): F20-25)

Behandlede patienter pr. 1.000 indbyggere på psykiatriske enheder (Samlet) (Diagnosegruppe (ICD-10): F28-29)

Behandlede patienter pr. 1.000 indbyggere på psykiatriske enheder (Samlet) (Diagnosegruppe (ICD-10): F30-39)

Behandlede patienter pr. 1.000 indbyggere på psykiatriske enheder (Mænd)

Behandlede patienter pr. 1.000 indbyggere på psykiatriske enheder (Mænd) (Diagnosegruppe

(ICD-10): F10-19)

Behandlede patienter pr. 1.000 indbyggere på psykiatriske enheder (Mænd) (Diagnosegruppe (ICD-10): F20-25)

Behandlede patienter pr. 1.000 indbyggere på psykiatriske enheder (Mænd) (Diagnosegruppe (ICD-10): F28-29)

Behandlede patienter pr. 1.000 indbyggere på psykiatriske enheder (Mænd) (Diagnosegruppe (ICD-10): F30-39)

Behandlede patienter pr. 1.000 indbyggere på psykiatriske enheder (Kvinder)

NOMESCO

NOMESCO

NOMESCO

NOMESCO

NOMESCO

NOMESCO

NOMESCO

NOMESCO

NOMESCO

NOMESCO

Behandlede patienter pr. 1.000 indbyggere på psykiatriske enheder (Kvinder) (Diagnosegruppe

(ICD-10): F10-19)

Behandlede patienter pr. 1.000 indbyggere på psykiatriske enheder (Kvinder) (Diagnosegruppe (ICD-10): F20-25)

Behandlede patienter pr. 1.000 indbyggere på psykiatriske enheder (Kvinder) (Diagnosegruppe (ICD-10): F28-29)

Behandlede patienter pr. 1.000 indbyggere på psykiatriske enheder (Kvinder) (Diagnosegruppe (ICD-10): F30-39)

NOMESCO

NOMESCO

NOMESCO

Generiske procesindikatorer for børn og unge til og med 17 år

Andel af behandlingsforløb med svag belastning ved afslutning eller efter $6 \mathrm{mdr}$.

BUP-basen

Andel af behandlingsforløb med god psykosocial funktion ved afslutning eller efter 6 . mdr.

Links:

- Det Nationale Indikatorprojekt http://www.nip.dk/forside/sygdomsomr\%C3\%A5der

- Landspatientregistreret, Sundhedsstyrelsen http://www.sst.dk/Indberetning\%20og\%20statistik/Landspatientre gisteret.aspx

- BUP-basen

http://www.bupnet.dk/page13.aspx 
Patienterne og de pårørende har ordet. Undersøgelse på de psykiatriske sengeafsnit i Danmark 2009

\author{
Spørgsmål til patientundersøgelsen \\ Kunne du komme i kontakt med personalet når du havde behov for det? \\ Var du tilfreds med kontakten med din(e) kontaktperson(er)? \\ Var du tilfreds med kontakten med din lægen/lægerne? \\ Synes du, at personalet viste hensyn og respekt over for dig som menneske? \\ Var der mulighed for, at du kunne tale uforstyrret med personalet på sengeafsnittet? \\ Var personalet godt forberedt til vigtige samtaler? \\ Var du tilfreds med de aktiviteter du kunne deltage i under indlæggelsen? \\ Var dine undersøgelser og behandling under hele indlæggelsen godt planlagt? \\ Fik du de informationer om din sygdom og behandling, som du havde brug for? \\ Har personalet informeret dig om, hvordan din livsstil kan påvirke din sygdom? \\ Var du tilfreds med den indflydelse du selv havde på din behandling? \\ Synes du, at du har fået den psykiatriske behandling, som du havde brug for på sengeafsnittet? \\ Oplevede du, at der var en god atmosfære på sengeafsnittet? \\ Var du tilfreds med din kontakt med de andre patienter? \\ Var du tilfreds med de fysiske rammer? \\ Var du tilfreds med den modtagelse du fik på dette sengeafsnit? \\ Har du fået det bedre af at være indlagt på sengeafsnittet? \\ Har indlæggelsen givet dig mere håb og livsmod i forhold til fremtiden? \\ Har du fået skriftlig information om din sygdom og behandling fra dette sengeafsnit? \\ Oplevede du, at der skete fejl under din indlæggelse? \\ Hvis ja, synes du personalet tog hånd om fejlen(e \\ Havde personalet på sengeafsnittet kontakt med dine pårørende? \\ Hvis ja, var du tilfreds med personalet $s$ kontakt med dine pårørende? \\ Hvis nej, ville du gerne have haft at personalet havde kontakt med dine pårørende? \\ Er der lavet aftaler om tiden efter din udskrivning? \\ Hvis ja, er du tilfreds med de aftaler der er lavet om tiden efter din udskrivning? \\ Hvis nej, ville du gerne have haft at der var lavet aftaler om tiden efter din udskrivning? \\ Hvad er dit samlede indtryk af din indlæggelse på dette afsnit? \\ Er der samarbejde med de forskellige steder, som du har kontakt med om din sygdom? \\ Hvis ja, er du tilfreds med det samarbejde der er mellem stederne? \\ Hvis nej, vil du gerne have at stederne skal samarbejde? \\ Har du fået tilbud om undervisning i den sygdom og behandling i psykiatrien? \\ Hvis nej, har du haft brug for undervisning? \\ Savner du behandlingstilbud i psykiatrien?
}

\title{
Spørgsmål til pårørendeundersøgelsen
}

Havde du og patienten mulighed for at tale uforstyrret sammen, når du besøgte patienten på dette sengeafsnit? Vidste du, hvem der var patientens kontakt-person(er) på sengeafsnittet?

Blev du inviteret til et møde i begyndelsen af patientens indlæggelse på sengeafsnittet?

Tog personalet selv initiativ til kontakt med dig?

Havde du mulighed for at tale med personalet på sengeafsnittet om dine forventninger til din

kontakt med dem?

Var personalet på sengeafsnittet interesseret i din erfaring og viden som pårørende?

Blev du medinddraget af personalet på sengeafsnittet?

Var det dit indtryk, at personalet på sengeafsnittet betragtede dig som samarbejdspartner (medspiller) i patien-

tens behandlingsforl $\varnothing \mathrm{b}$ ?

Fik du den st $\varnothing t t e$ og opbakning fra personalet på sengeafsnittet, som du havde brug for?

Hvad er dit samlede indtryk af sengeafsnittets kontakt med dig?

Hvad havde størst betydning for dig i din kontakt med sengeafsnittet?

Har du fået de informationer om patientens sygdom, som du har haft brug for?

Har du fået de informationer om patientens behandling, som du har haft brug for?

Har der været overensstemmelse mellemde oplysninger, du har fået af behandlere forskellige steder i psykiatrien?

Er du blevet tilbudt undervisning om psykiske sygdomme og behandling?

Hvis nej: Har du haft brug for undervisning?

Er du blevet informeret om pårørenderådgivninger?

Savner du tilbud til dig som pårørende i psykiatrien?

Hvis ja, hvad savnede du?

Er det dit indtryk, at patienten får den rette hjælp/støtte/behandling i det psykiatriske system som helhed?

Er det dit indtryk, at personalet i psykiatriensom helhed støtter patienten i at have kontakt med sine pårørende?

Hvor belastet føler du dig selv af patientens sygdom og problemer?

Hvor længe har patienten været indlagt på dette sengeafsnit?

Hvilke af følgende instanser har patienten haft kontakt med inden for de sidste par år vedrørende sin psykiske sygdom? 
Patienten og deres forældre har ordet. Undersøgelse i de børne- og ungdomspsykiatriske dag- og døgnafsnit i Danmark 2007-08

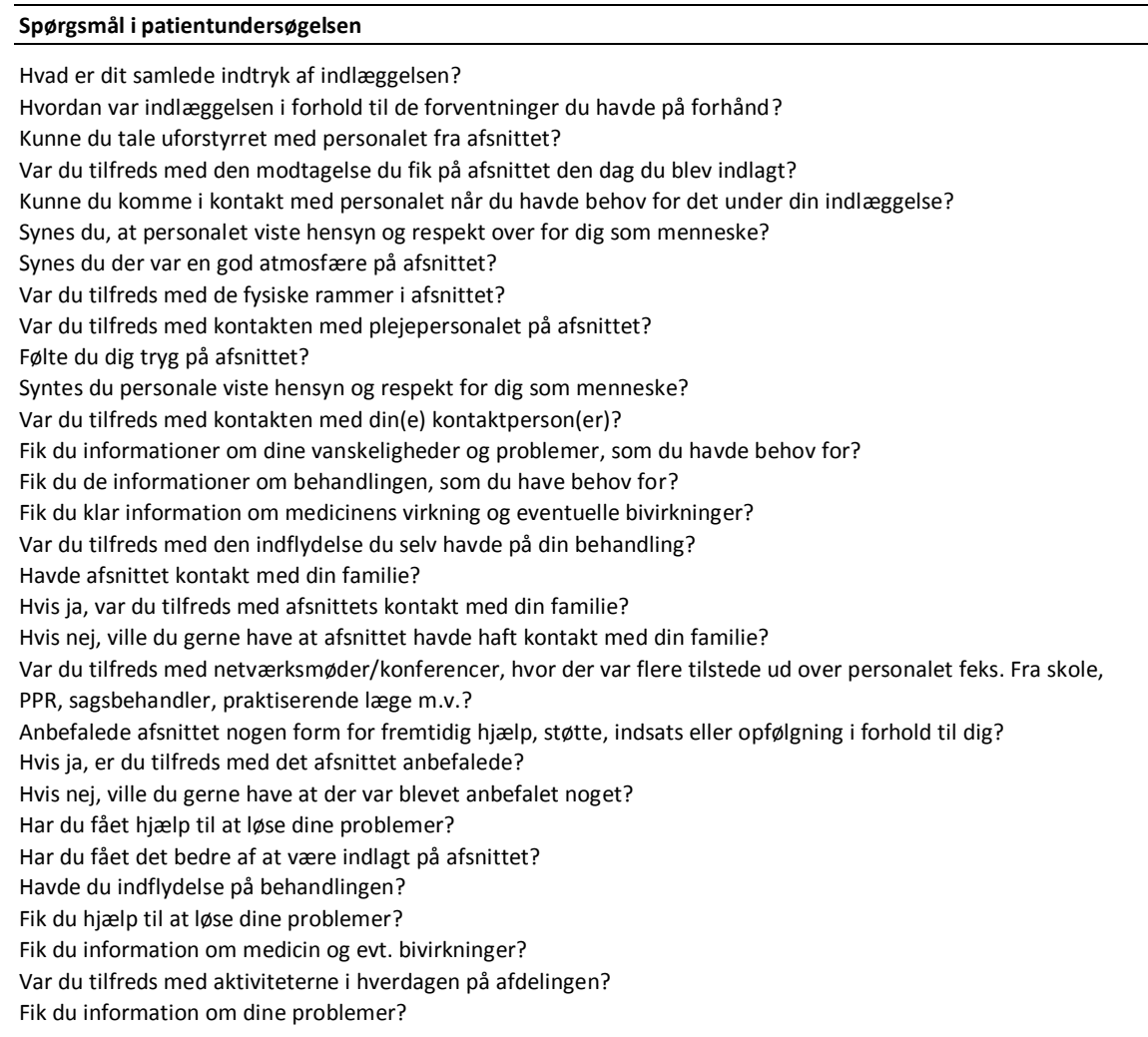

Spørgsmål i forældreundersøgelsen

Er din oplevelse at barnet/den unge følte sig tryg på afsnittet?

Følte du dig tryg under barnets/den unges indlæggelse på afsnittet?

Kunne du tale uforstyrret med personalet fra afsnittet?

Oplevede du at personalet var interesseret i dine erfaringer og viden om barnet/den unge?

Blev du inddraget $\mathrm{i}$ indlæggelsesforløbet i det omfang, som du selv gerne ville det?

Er det dit indtryk at behandlerne betragtede dig som samarbejdspartner?

Fik du de informationer om barnets/den unges vanskeligheder og problemer som du havde behov for?

Fik du de informationer om behandlingen, som du havde behov for?

Fik du klar information om medicinens virkning og evt. bivirkninger?

Fik du den støtte og opbakning fra personalet på afsnittet som du havde behov for?

Var du tilfreds med netværksmøder/konferencer, hvor der var flere tilstede ud over personalet feks. Fra skole,

PPR, sagsbehandler, praktiserende læge m.v.?

Var du tilfreds med de fysiske rammer i afsnittet?

Synes du, at den øvrige familie/pårørende blev inddraget i passende grad?

Synes du at den barnets/unges daginstitution/skole/uddannelsessted blev inddraget i passende grad?

Fik du hjælp til hvordan du kan forholde dig til barnet/den unge i dagligdagen efter indlæggelsen?

Anbefalede afsnittet nogen form for fremtidig støtte/behandling i forhold til barnet/den unge?

Hvis ja, er du tilfreds med det anbefalede?

Hvis nej, ville du gerne have at der var blevet anbefalet noget?

Er det din oplevelse at barnet/den unge har fået det bedre som følge af indlæggelsen?

Hvordan var indlæggelsen i forhold til de forventninger du havde på forhånd?

Hvad er dit samlede indtryk af indlæggelsen?

Er det dit indtryk at der e et passende samarbejde mellem de forskellige offentlige steder som barn et/den unge har kontakt med?

Er det dit indtryk, at der er tilstrækkelige tilbud til barnet/den unge i det sociale system, sko-

le/uddannelsessystemet, psykiatrien m.fl.?

Er det dit indtryk, at der er tilstrækkelige tilbud til familien i forbindelse med barnets/den unges problemer? 


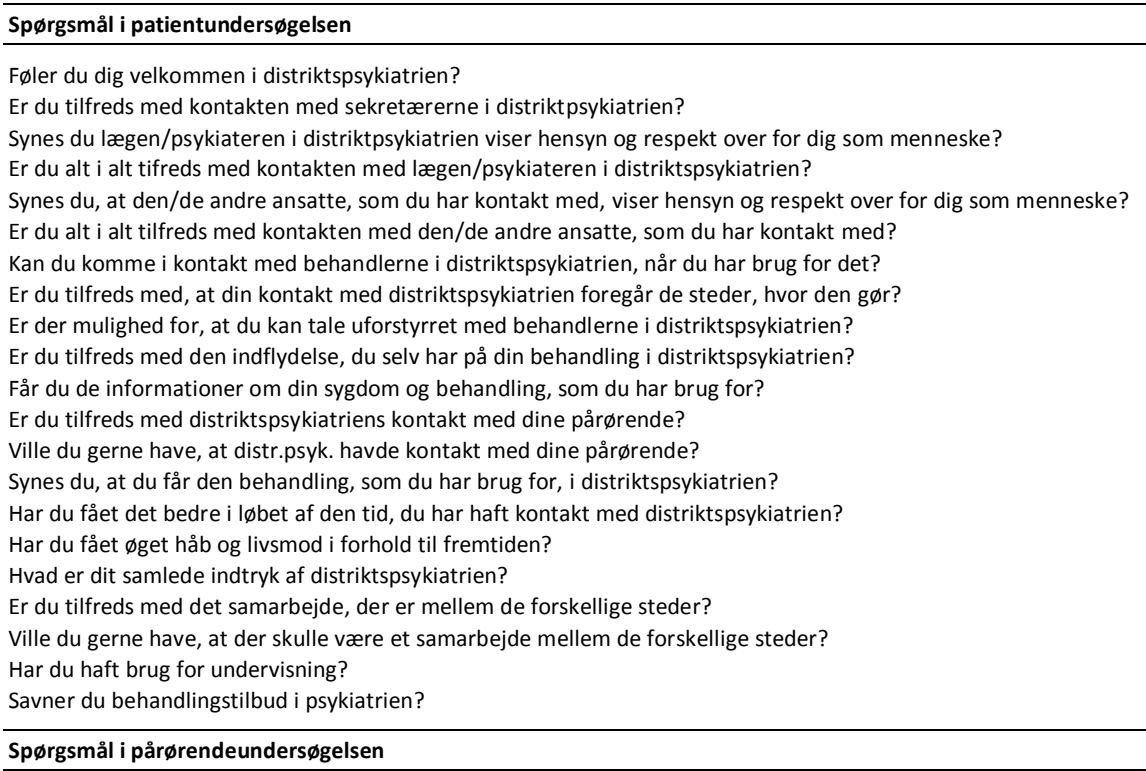

Spørgsmål i pårørendeundersøgelsen

Kan du komme i kontakt med distriktspsykiatrien, når du har behov for det? Ved du, hvem der er patientens behandler(e) i distriktspsykiatrien? Ved du, hvem der er patientens behandler(e) i distriktspsykiatrien? Ved du, hvem der er patientens behandler(e) i distriktspsykiatrien? Ved du, hvem der er patientens behandler(e) i distriktspsykiatrien? Er du blevet medinddraget af personalet i distriktspsykiatrien?

Er det dit indtryk, at personalet i distriktspsykiatrien betragter dig som samarbejdspartner (medspiller) i patientens behandlingsforløb?

Har du fået den støtte og opbakning fra personalet i distriktspsykiatrien, som du har haft brug for? Hvad er dit samlede indtryk af distriktspsykiatriens kontakt med dig?

Har du fået de informationer om patientens sygdom, som du har haft brug for?

Har du fået de informationer om patientens behandling, som du har haft brug for?

Har der været overensstemmelse mellem de oplysninger, du har fået af behandlere forskellige steder i psykiatrien?

Er du blevet tilbudt undervisning om psykiske sygdomme og behandling?

Hvis nej: Har du haft brug for undervisning?

Er du blevet informeret om nogen pårørenderådgivninger?

Savner du tilbud til dig som pårørende i psykiatrien?

Er det dit indtryk, at patienten får den rette hjælp/støtte/behandling i det psykiatriske system som helhed?

Er det dit indtryk, at personalet i psykiatrien som helhed støtter patienten i at have kontakt med sine pårørende?

- Link til psykiatriundersøgelsen på sengeafsnit: http://www.regioner.dk/Aktuelt/Nyheder/2010/Februar/ /media /Filer/Social\%20og\%20psykiatri/Landsrapport\%202009.ashx

- Link til undersøgelsen på børne- og ungdomspsykiatriske dag- og døgnafsnit:

http://www.regionmidtjylland.dk/files/Sundhed/Sundhedsstaben/C enter\%20for\%20Kvalitetsudvikling/psykiatri/unders\%C3\%B8gelse smateriale/dag_dogn\%20afs/Koncept_\%20Dagdognafsnit\%202007-08.pdf

- Link til Distriktspsykiatriundersøgelsen: http://www.bedrepsykiatri.dk/media/31679/landsrapport_dp2.pdf 


\section{Norge}

Kvalitetsindikatorer målt innen psykisk helsevern voksne i 2010 Adult psychiatry in dicator measurements 2010

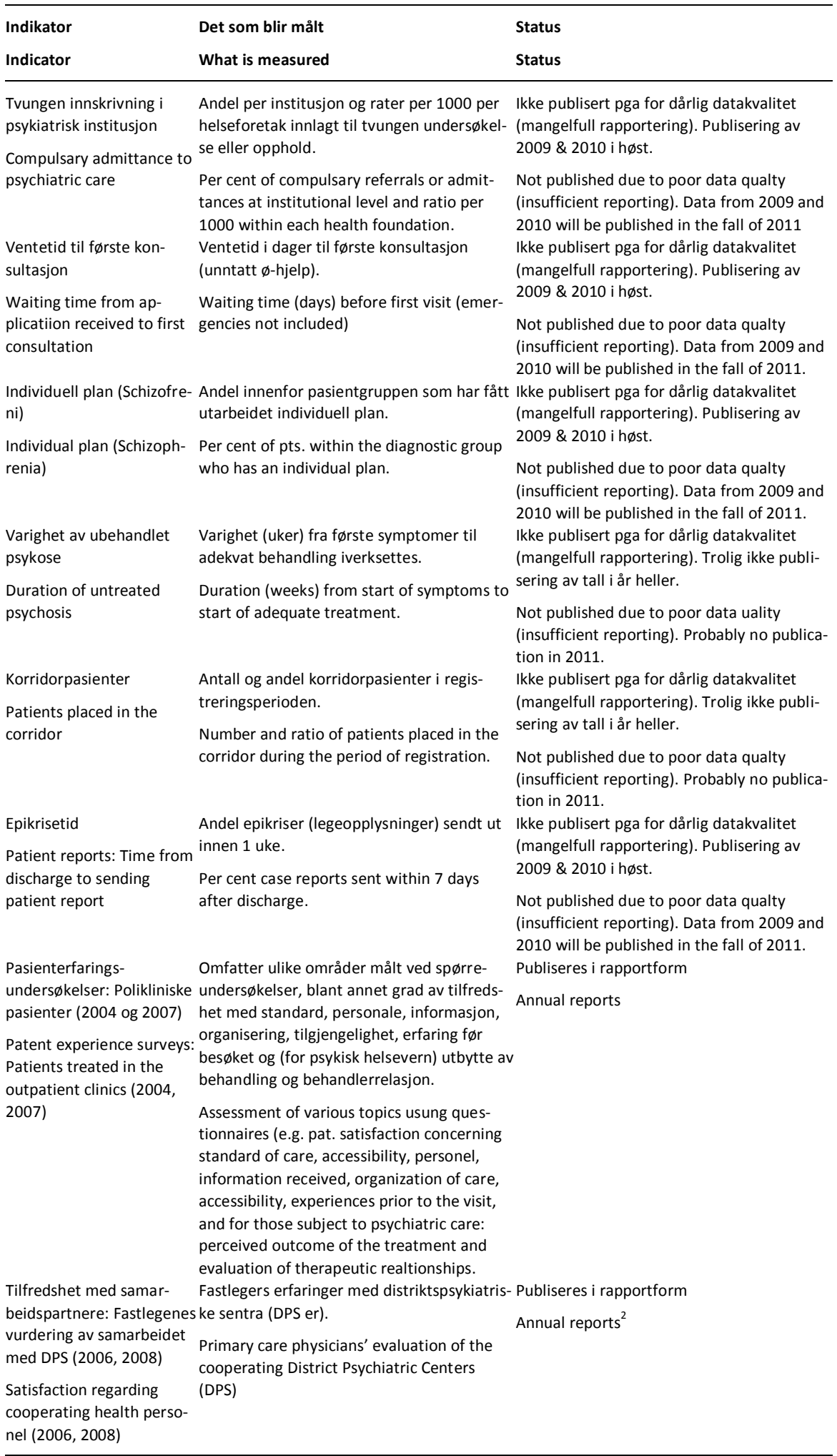


- Link til poliklinikk for voksne i psykisk helsevern 2007: http://www.kunnskapssenteret.no/Publikasjoner/Brukererfaringer +med+poliklinikker+for+voksne+i+psykisk+helsevern.+Nasjonale+re sultater $+\mathrm{i}+2007+$ og + utvikling + fra $+2004.5318 . \mathrm{cms}$

- Link til poliklinikk for voksne i psykisk helsevern 2004: http://www.kunnskapssenteret.no/Publikasjoner/Pasienterfaringer +ved+poliklinikker+for+voksne+i+det+psykiske+helsevernet+i+Norg e+\%E2\%80\%93+Hovedresultater.1812.cms

Kvalitetsindikatorer målt innen psykisk helsevern barn og unge i 2010 Child and Adolescent Psychiatry indicator measurements $\mathbf{2 0 1 0}$

\begin{tabular}{lll}
\hline Indikator & Det som blir målt & Stat \\
Indicator & What is measured & Stat \\
\hline
\end{tabular}

Individuell plan (ADHD)

Individual Plan

Andel diagnostisk vurdert innen barne- og ungdomspsykiatrien

Per cent of patiens diagnosed with the diagnostic system used in child and adolescent psyschiatry

Epikrisetid

Time from discharge to sending patient report

Ventetid første konsultasjon

Waiting time from applicatiion received to first consultation

Varighet av ubehandlet psykose Duration untreated psychosis

Foresattes vurderinger av tilbudet ved barne- og ungdomspsykiatriske poliklinikker i 2006

Next-of-kins evaluation of services from children and adolescents outpatient clinics 2006
Andel innenfor pasientgruppen som lkke publisert pga for dårlig datakvalitet har fått utarbeidet individuell plan. (mangelfull rapportering). Publisering av Per cent of eligible patients equipped with Individual Plan 2009 \& 2010 i høst.

Not published due to poor data qualty (insufficient reporting). Data from 2009 and 2010 will be published in the fall of 2011.

Andel pasienter som har fått diagno- Data fra 2006-2008 ligger ute. se i diagnosesystemet som benyttes i http://nesstar2.shdir.no/kvalind/ barne- og ungdomspsykiatrien. 2009-data planlegges lagt ut i høst. (Multiaksialt diagnosesystem). Data for 2006-2008 accessible on the net. Per cent of patients with diagnosis http://nesstar2.shdir.no/kvalind/ based on the multi dimensional Data for $\mathbf{2 0 0 9}$ will be published in the fall disagnostic system used in child and 2011. adolescent psychiatry

Andel epikriser (legeopplysninger) Data fra 2006-2008 ligger ute. sendt ut innen 1 uke. http://nesstar2.shdir.no/kvalind/ Per cent case reports sent within 7 2009-data planlegges lagt ut i høst. days after discharge Data for 2006-2008 accessible on the net. Data for 2009 will be published in the fall 2011.

Ventetid i dager til første konsulta- Data fra 2006-2008 ligger ute. sjon (unntatt $\varnothing$-hjelp). http://nesstar2.shdir.no/kvalind/ Waiting time (days) before first visit 2009-data planlegges lagt ut i høst 2011

(emergencies not included)

Data for 2006-2008 accessible on the net. http://nesstar2.shdir.no/kvalind/ Data for 2009 will be published in the fall 2011.

Varighet (uker) fra første symptomer Ikke publisert pga for dårlig datakvalitet til adekvat behandling iverksettes. (mangelfull rapportering). Trolig ikke Waiting time (weeks) from symptom start to start of adequate treatment Not published due to poor data qualty (insufficient reporting). Probably no publication in 2011 Publiseres i rapportform Annual reports ${ }^{3}$

- http://www.kunnskapssenteret.no/Publikasjoner/Foresattes+vurde ringer+av+tilbudet+ved+barne+og+ungdomspsykiatriske+poliklinik ker+i+2006+Resultater+fra+en+nasjonal+unders\%C3\%B8kelse.201 $4 . \mathrm{cms}$ 


\section{Sverige}

\section{Nationella indikatorer inom ramen för Nationella riktlinjer för psykiatriområdet i Sverige}

\section{Nationella riktlinjer}

Socialstyrelsens Nationella riktlinjer är ett stöd vid prioriteringar och ger vägledning om vilka behandlingar och metoder som olika verksamheter i vård och omsorg bör satsa resurser på. Syftet med Socialstyrelsens nationella riktlinjer är att de ska vara ett stöd för beslutsfattare i landsting och regioner så att dessa kan styra hälso- och sjukvården genom öppna och systematiska prioriteringar. Riktlinjerna riktar sig till såväl beslutsfattare som verksamhetsledningar och är ett stöd för styrning och ledning på alla nivåer inom hälso- och sjukvården och omsorg.

\section{Nationella indikatorer}

Socialstyrelsen har utarbetat Nationella indikatorer inom ramen för arbetet med Nationella riktlinjer för psykosociala insatser vid schizofreni eller schizofreniliknande tillstånd och för vård vid depression och ångestsyndrom. Indikatorerna skall spegla god vård inom hälso- och sjukvården och socialtjänsten. Indikatorerna utgår från centrala rekommendationer i riktlinjerna.

Ett stort problem inom psykiatriområdet är dock att det i stor utsträckning saknas datakällor. Det innebär att ett antal av de framtagna indikatorerna ännu inte är möjliga att följa kontinuerligt på nationell nivå. Ett ytterligare problem är avsaknaden av individdata. Det innebär att framtagna indikatorer som ska spegla tillämpningen av rekommenderade åtgärder i primärvården, socialtjänsten och den psykiatriska verksamheten huvudsakligen är på strukturnivå och vissa är processmått i nuläget.

Indikatorer för Nationella riktlinjer för psykosociala insatser vid schizofreni eller schizofreniliknande tillstånd 2011

Socialstyrelsen har tagit fram 15 nationella indikatorer för hälso- och sjukvården (den psykiatriska verksamheten) och 12 nationella indikatorer för socialtjänstens verksamhet för personer med psykisk funktionsnedsättning.

Indikatorer för Nationella riktlinjer för vård vid depression och ångestsyndrom 2010

Socialstyrelsen har tagit fram 18 stycken nationella indikatorer för vården av dessa patientgrupper.

Fördjupning

Nationella riktlinjer och fullständiga listor över Nationella indikatorer går att ladda ned från Socialstyrelsens hemsida: 
- Nationella riktlinjer för psykosociala insatser vid schizofreni eller schizo-freniliknande tillstånd 2011

http://www.socialstyrelsen.se/nationellariktlinjerforpsykosocialains atservidschizofreni

- Fullständig lista över indikatorer http://www.socialstyrelsen.se/publikationer2011/2011-13/Documents/indikatorer.pdf

- Nationella riktlinjer för vård vid depression och ångestsyndrom 2010 http://www.socialstyrelsen.se/nationellariktlinjerfordepressionocha ngest

- Fullständig lista över indikatorer http://www.socialstyrelsen.se/nationellariktlinjerfordepressionocha ngest/Documents/Bilaga\%204_Kvalitetsindikatorer.pdf 
Översikt över publicerade indikatorer

Depression

Överdödlighet för patienter med depression

Somatisk slutenvård för patienter med depression

Följsamhet till antidepressiv läkemedelsbehandling

Återintagningar i psykiatrisk heldygnsvård av patienter med bipolär diagnos

ECT-behandling för patienter med svår till mycket svår egentlig depressionsepisod

Behandling med litium respektive antipsykotiska läkemedel för patienter med manisk episod vid bipolär sjuk-

dom

Återfallsförebyggande läkemedelsbehandling med litium för patienter som uppnått remission efter manisk eller depressiv period vid bipolär sjukdom

Planlagd utbildning för att öka patientens kunskap om hennes eller hans bipolära sjukdom

Psykologisk behandling med KBT vid egentlig depressionsepisod

Uppföljning via telefon eller återbesök minst två gånger första månaden efter att läkemedelsbehandling satts in

Andelen vars antidepressiva medicinering, vid nyinsättning, utvärderas inom 3 månader

Andelen personer som använder lugnande medel eller sömnmedel utan ordination, vid depression.

Återskrivning inom 14 respektive 28 dagar efter vård för bipolär sjukdom

Återskrivning inom 3 respektive 6 månader efter vård för bipolär sjukdom

Läkarkontakt i specialiserad öppenvård efter utskrivning for bipolär sjukdom

Undvikbar somatisk slutenvård efter vård for bipolär sjukdom

Dödlighet bland vårdade för bipolär sjukdom

Följsamhet till lituimbehandling vid bipolär sjukdom

Återskrivning inom 14 respektive 28 dagar efter vård for svår depression

Återskrivning inom 3 respektive 6 månader efter vård för svår depression

Läkarkontakt i specialiserad öppenvård efter utskrivning för svår depression

Undvikbar somatisk slutenvård efter vård för svår depression

Dödlighet bland vårdade för svår depression

Följsamhet till behandling med antidepressiva läkemedel

\section{Schizofren}

Överdödlighet för patienter med schizofreni

Återintagningar i psykiatrisk slutenvård av patienter med schizofreni

Tillgång till tidiga och samordnade åtgärder för personer som är nyinsjuknade i psykossjukdom

Tillgång till familjeinterventioner

Tillgång till stöd $\mathrm{i}$ föräldraskapet

Tillgång till integrerad psykologisk terapi

Tillgång till social färdighetsträning

Tillgång till arbetslivsinriktad rehabilitering enligt IPS-modellen

Tillgång till samordnade vård- och stödåtgärder enligt ACT-modellen

Överenskommelse om samarbete mellan kommun och landsting

Uppföljningssystem för åtgärder på individnivå

Återskrivning inom 14 respektive 28 dagar efter vård för schizofreni

Återskrivning inom 3 respektive 6 månader efter vård för schizofreni

Läkarkontakt i specialiserad öppenvård efter utskrivning för schizofreni

Undvikbar somatisk slutenvård efter vård för schizofreni

Dödlighet bland vårdade för schizofreni

Antipsykotiska läkemedel vid schizofren

Hjälp till bostad vid hemlöshet (Bostad först)

Gemensam inventering av behovet av åtgärder hos personer med psykisk funktionsnedsättning 


\section{Bilag 3: Oversigt over nationale kliniske retningslinjer med links}

Danmark

- Referenceprogram for angsttilstande hos voksne - 2007 http://www.sst.dk/publ/Publ2007/PLAN/SfR/SST_Angstrapport_w eb.pdf

- Behandling af depressionssygdomme - 2005

- Kommentering af: Behandling af depressionssjukdomar. En systematisk litteraturöversikt. Volym 1-3. Statens beredning för medicinsk utvärdering http://www.sst.dk/publ/Publ2005/CEMTV/KUMTV/KUMTVdepress ion.pdf

- Referenceprogram for unipolar depression hos voksne - 2007 http://www.sst.dk/publ/Publ2007/PLAN/SfR/SST_Dep.rapport.pdf

- Referenceprogram for skizofreni 2004 http://www.sst.dk/publ/Publ2004/RefprogSkizo.pdf

- Referenceprogram for udredning og behandling af børn og unge med ADHD - april 2008 http://www.bupnet.dk/media/ADHDReferenceprogram080508_jsb[ 1].pdf

- Vejledning om behandling med antipsykotiske lægemidler til patienter over 18 år https://www.retsinformation.dk/Forms/R0710.aspx?id=11418

- Vejledning om medikamentel behandling af børn og unge med psykiske lidelser https://www.retsinformation.dk/Forms/R0710.aspx?id=114817

- Demens - den fremtidige tilrettelæggelse af sundhedsvæsenets indsats vedrørende diagnostik og behandling. Redegørelse fra Sundhedsstyrelsens arbejdsgruppe vedrørende demens, 2001 http://www.sst.dk/publ/Publ2001/Demens/index.htm

- National kliniske retningslinjer for Demens er under udarbejdelse 


\section{Finland}

- Skizofreni

http://www.kaypahoito.fi/web/kh/suositukset/naytaartikkeli/tunn us/hoi35050 (på finska)

http://www.kaypahoito.fi/web/svenska/patienter/naytaartikkeli/tu nnus/khr00004 (på svenska)

- Depression http://www.kaypahoito.fi/web/kh/suositukset/naytaartikkeli/tunn us/hoi50023 (på finska)

http://www.kaypahoito.fi/web/english/summaries/naytaartikkeli/t unnus/ccs00062 (in English)

- Bipolar lidelse

http://www.kaypahoito.fi/web/kh/suositukset/naytaartikkeli/tunn us/hoi50076 (på finska)

http://www.kaypahoito.fi/web/english/summaries/naytaartikkeli/t unnus/ccs00045 (in English)

- ADHD

http://www.kaypahoito.fi/web/kh/suositukset/naytaartikkeli/tunn us/hoi50061 (på finska)

http://www.kaypahoito.fi/web/svenska/patienter/naytaartikkeli/tu nnus/khr00068 (på svenska)

\section{Island}

- Island har ikke nationale kliniske retningslinjer for: schizofreni; depression eller bipolar lidelse.

- Island har nationale kliniske retningslinjer for Anoreksi http://www.landlaeknir.is/pages/96?query=

- Island har brugt kliniske retningslinjer fra National Institute for Clinical Excellence (NICE), Core guidelines in the treatment and management of anorexia nervosa, bulimia nervosa and related eating disorders,

- Island har national vejleder i diagnostik og behandling af ADHD. Diagnostikk og behandling av hyperkinetiske forstyrrelse/attention deficit hyperactivity disorder (AD/HD) hos barn, ungdom og voksne. http://www.landlaeknir.is/pages/1231 Er under revidering og ferdigstilles i mars 2011.

- Island har nationale kliniske retningslinjer for i diagnostik og behandling af alcoholmisbug i primer helsetjenesten.

- Island har brugt kliniske retningslinjer fra Scottish Intercollegiate Guidelines Network (SIGN) The management of harmful drinking and alcohol dependence in primary care.

http://www.landlaeknir.is/pages/1210?query= 
- Island har nationale kliniske retningslinjer for hvordan man handler suicide attempter og vurdering af suicide risk.

http://landspitali.is/Pages/14769

\section{Norge}

- Veileder i diagnostikk og behandling av ADHD. Diagnostikk og behandling av hyperkinetiske forstyrrelse/attention deficit hyperactivity disorder (AD/HD) hos barn, ungdom og voksne. ( IS1244. Utgitt av Sosial- og helsedirektoratet 2005. Er under revidering til nasjonal retningslinje, ferdigstilles i løpet av 2011). http://www.helsedirektoratet.no/publikasjoner/veiledere/veileder_ for_diagnostisering_og_behandling_av_ad_hd_33281

- Retningslinje for forebygging av selvmord i psykisk helsevern. (IS1511. Utgitt av Helsedirektoratet 2008). http://www.helsedirektoratet.no/vp/multimedia/archive/00036/IS -1511_Selvmord_kor_36439a.pdf

- Nasjonale retningslinjer for diagnostisering og behandling av voksne med depresjon i primær- og spesialisthelsetjenesten. ( IS-1561. Utgitt av Helsedirektoratet 2009).

http://www.helsedirektoratet.no/publikasjoner/nasjonale_faglige_r etningslinjer/nasjonale_retningslinjer_for_diagnostisering_og_behan dling_av_voksne_med_depresjon_i_prim_r_og_spesialisthelsetjeneste n_443184

- Nasjonale retningslinjer for utredning og behandling av bipolare lidelser er under utarbeidelse, utgis av Helsedirektoratet, ferdigstilles i løpet av 2011.

(Erstatter: Stemningslidelser. Kliniske retningslinjer for utredning og behandling. Utgitt av Statens helsetilsyn 2000). Ingen link foreløpig.

- Nasjonale retningslinjer for utredning, behandling og oppfølging av psykoselidelser er under utarbeidelse, utgis av Helsedirektoratet, ferdigstilles i løpet av 2011/2012. (Erstatter: Schizofreni. Kliniske retningslinjer for utredning og behandling. Utgitt av Statens helsetilsyn 2000). Ingen link foreløpig.

- Nasjonale retningslinjer for utredning og behandling av spiseforstyrrelser er under utarbeidelse, utgis av Helsedirektoratet, ferdigstilles i løpet av 2013. ( Erstatter: Alvorlige spiseforstyrrelser.

Retningslinjer for behandling i spesialisthelsetjenesten. Utgitt av Statens helsetilsyn 2000). Ingen link foreløpig.

- Veileder for poliklinikkene. Psykisk helsevern for barn og unge. (IS1570. Utgitt av Helsedirektoratet 2008). http://www.helsedirektoratet.no/publikasjoner/veiledere/psykisk_ helsevern_for_barn_og_unge_veileder_for_poliklinikker_242924

- Veileder. Vurdering av henvisninger til tverrfaglig spesialisert rusbehandling ( IS-1505. Utgitt av Helsedirektoratet 2008). 
http://www.helsedirektoratet.no/prioriteringer_helsetjenesten/publ ikasjoner/vurdering_av_henvisninger_til_tverrfaglig_spesialisert_rus behandling_235934

- Veileder. Fra bekymring til handling. En veileder om tidlig intervensjon på rusområdet. ( IS-1742. Utgitt av Helsedirektoratet 2009).

http://www.helsedirektoratet.no/publikasjoner/veiledere/fra_beky mring_til_handling_en_veileder_om_tidlig_intervensjon_prusomr_det_ 503574

- Nasjonal retningslinje for legemiddelassistert rehabilitering (LAR) ved opioidavhengighet. (IS-1701. Utgitt av Helsedirektoratet 2010). http://www.helsedirektoratet.no/publikasjoner/nasjonale_faglige_r etningslinjer/nasjonal_retningslinje_for_legemiddelassistert_rehabilit ering_ved_opioidavhengighet_671814

- Nasjonale retningslinjer for gravide i LAR og oppfølging av familiene frem til barnet når skolealder. Er på høring. Utgis av Helsedirektoratet og ferdigstilles i løpet av 2011/2012. Ingen link foreløpig.

- Nasjonal retningslinje for utredning, behandling og oppfølging av personer med samtidig rus- og psykisk lidelse - ROP-lidelser, er under utarbeidelse, utgis av Helsedirektoratet, ferdigstilles i 2011. (Erstatter: Personer med samtidig alvorlig psykisk lidelse og omfattende rusmisbruk. Utgitt av Statens helsetilsyn 2000). Ingen link foreløpig.

- Pårørende en ressurs. ( IS-1512. Utgitt av Helsedirektoratet 2008). http://www.helsedirektoratet.no/publikasjoner/veiledere/p_r_rend e__en_ressurs_271634

- Distriktspsykiatriske sentra. (IS-1388. Utgitt av Helsedirektoratet 2006). http://www.helsedirektoratet.no/publikasjoner/veiledere/distrikts psykiatriske_sentre_54489

- Veileder om helsetjenestetilbud til innsatte i fengsel. ( IS-1190. Utgitt av Helsedirektoratet 2004).

http://www.helsedirektoratet.no/publikasjoner/veiledere/veileder_ om_helsetjenestetilbud_til_innsatte_i_fengsel_2724

\section{Sverige}

- Nationella riktlinjer för depression och ångest: http://www.socialstyrelsen.se/nationellariktlinjerfordepressionocha ngest

- Nationella riktlinjer för psykosociala insatser vid schizofreni eller schizofreniliknande tillstånd http://www.socialstyrelsen.se/nationellariktlinjerforpsykosocialains atservidschizofreni 


\section{Bilag 4. Samlet liste i denne rapport med indikatorer indenfor psykiatrien}

Skizofreni (voksne) ICD-10 kode: F20

Basisindikatorer

Antal indlagte nydiagnosticerede patienter med skizofreni med kontakt til sekundær sektor pr. 100.000 indbyggere pr. år (Samlet)

Antal ambulante nydiagnosticerede patienter med skizofreni med kontakt til sekundær sektor pr. 100.000 indbyggere pr. år (Samlet)

Samlet antal nydiagnosticerede patienter med skizofreni med kontakt til sekundær sektor pr. 100.000 indbyggere pr. år (Samlet)

Antal nydiagnosticerede patienter med skizofreni med kontakt til sekundær sektor pr. år (Samlet)

Antal indlagte nydiagnosticerede patienter med skizofreni med kontakt til sekundær sektor pr. 100.000 indbyggere pr. år (Mænd)

Antal ambulante nydiagnosticerede patienter med skizofreni med kontakt til sekundær sektor pr. 100.000 indbyggere pr. år (Mænd)

Samlet antal nydiagnosticerede patienter med skizofreni med kontakt til sekundær sektor pr. 100.000 indbyggere pr. år (Mænd)

Antal nydiagnosticerede patienter med skizofreni med kontakt til sekundær sektor pr. år (Mænd) Antal indlagte nydiagnosticerede patienter med skizofreni med kontakt til sekundær sektor pr. 100.000 indbyggere pr. år (Kvinder)

Antal ambulante nydiagnosticerede patienter med skizofreni med kontakt til sekundær sektor pr. 100.000 indbyggere pr. år (Kvinder)

Samlet antal nydiagnosticerede patienter med skizofreni med kontakt til sekundær sektor pr. 100.000 indbyggere pr. år (Kvinder)

Antal nydiagnosticerede patienter med skizofreni med kontakt til sekundær sektor pr. år (Kvinder)

Antal indlagte nydiagnosticerede patienter med skizofreni og misbrugsdiagnose med kontakt til sekundær sektor pr. 100.000 indbyggere pr. år (Samlet) (ICD-10: F10-F19)

Antal ambulante nydiagnosticerede patienter med skizofreni og misbrugsdiagnose med kontakt til sekundær sektor pr. 100.000 indbyggere pr. år (Samlet) (ICD-10: F10-F19)

Samlet antal nydiagnosticerede patienter med skizofreni og misbrugsdiagnose med kontakt til sekundær sektor pr. 100.000 indbyggere pr. år (Samlet) (ICD-10: F10-F19)

Antal nydiagnosticerede patienter med skizofreni og misbrugsdiagnose med kontakt til sekundær sektor pr. år (Samlet) (ICD-10: F10-F19)

Antal indlagte nydiagnosticerede patienter med skizofreni og misbrugsdiagnose med kontakt til sekundær sektor pr. 100.000 indbyggere pr. år (Mænd) (ICD-10: F10-F19)

Antal ambulante nydiagnosticerede patienter med skizofreni og misbrugsdiagnose med kontakt til sekundær sektor pr. 100.000 indbyggere pr. år (Mænd) (ICD-10: F10-F19)

Samlet antal nydiagnosticerede patienter med skizofreni og misbrugsdiagnose med kontakt til sekundær sektor pr. 100.000 indbyggere pr. år (Mænd) (ICD-10: F10-F19)

Antal nydiagnosticerede patienter med skizofreni og misbrugsdiagnose med kontakt til sekundær sektor pr. år (Mænd) (ICD-10: F10-F19)

Antal indlagte nydiagnosticerede patienter med skizofreni og misbrugsdiagnose med kontakt til sekundær sektor pr. 100.000 indbyggere pr. år (Kvinder) (ICD-10: F10-F19)

Antal ambulante nydiagnosticerede patienter med skizofreni og misbrugsdiagnose med kontakt til sekundær sektor pr. 100.000 indbyggere pr. år (Kvinder) (ICD-10: F10-F19)

Samlet antal nydiagnosticerede patienter med skizofreni og misbrugsdiagnose med kontakt til sekundær sektor pr. 100.000 indbyggere pr. år (Kvinder) (ICD-10: F10-F19)

Antal nydiagnosticerede patienter med skizofreni og misbrugsdiagnose med kontakt til sekundær sektor pr. år (Kvinder) (ICD-10: F10-F19)

Antal diagnosticerede patienter med skizofreni, som har haft kontakt med sekundær sektor pr. 100.000 indbyggere pr. år (Samlet)

Antal diagnosticerede patienter med skizofreni, som har haft kontakt med sekundær sektor pr. 100.000 indbyggere pr. år (Samlet) (aldersgrupper: 18-24)

Antal diagnosticerede patienter med skizofreni, som har haft kontakt med sekundær sektor pr. 100.000 indbyggere pr. år (Samlet) (aldersgrupper: 25-44)

Antal diagnosticerede patienter med skizofreni, som har haft kontakt med sekundær sektor pr. 100.000 indbyggere pr. år (Samlet) (aldersgrupper: 45-64) 
Antal diagnosticerede patienter med skizofreni, som har haft kontakt med sekundær sektor pr. 100.000 indbyggere pr. år (Samlet) (aldersgrupper: 65-84)

Antal diagnosticerede patienter med skizofreni, som har haft kontakt med sekundær sektor pr. 100.000 indbyggere pr. år (Samlet) (aldersgrupper: 85+)

Antal diagnosticerede patienter med skizofreni, som har haft kontakt med sekundær sektor pr. 100.000 indbyggere pr. år (Mænd)

Antal diagnosticerede patienter med skizofreni, som har haft kontakt med sekundær sektor pr. 100.000 indbyggere pr. år (Mænd) (aldersgrupper: 18-24)

Antal diagnosticerede patienter med skizofreni, som har haft kontakt med sekundær sektor pr. 100.000 indbyggere pr. år (Mænd) (aldersgrupper: 25-44)

Antal diagnosticerede patienter med skizofreni, som har haft kontakt med sekundær sektor pr. 100.000 indbyggere pr. år (Mænd) (aldersgrupper: 45-64)

Antal diagnosticerede patienter med skizofreni, som har haft kontakt med sekundær sektor pr. 100.000 indbyggere pr. år (Mænd) (aldersgrupper: 65-84)

Antal diagnosticerede patienter med skizofreni, som har haft kontakt med sekundær sektor pr. 100.000 indbyggere pr. år (Mænd) (aldersgrupper: 85+)

Antal diagnosticerede patienter med skizofreni, som har haft kontakt med sekundær sektor pr. 100.000 indbyggere pr. år (Kvinder)

Antal diagnosticerede patienter med skizofreni, som har haft kontakt med sekundær sektor pr. 100.000 indbyggere pr. år (Kvinder) (aldersgrupper: 18-24)

Antal diagnosticerede patienter med skizofreni, som har haft kontakt med sekundær sektor pr. 100.000 indbyggere pr. år (Kvinder) (aldersgrupper: 25-44)

Antal diagnosticerede patienter med skizofreni, som har haft kontakt med sekundær sektor pr. 100.000 indbyggere pr. år (Kvinder) (aldersgrupper: 45-64)

Antal diagnosticerede patienter med skizofreni, som har haft kontakt med sekundær sektor pr. 100.000 indbyggere pr. år (Kvinder) (aldersgrupper: 65-84)

Antal diagnosticerede patienter med skizofreni, som har haft kontakt med sekundær sektor pr. 100.000 indbyggere pr. år (Kvinder) (aldersgrupper: 85+)

Antal diagnosticerede patienter med skizofreni med misbrugsdiagnose, som har haft kontakt med sekundær sektor pr. 100.000 indbyggere pr. år (Samlet) (ICD-10: F10-F19)

Antal diagnosticerede patienter med skizofreni med misbrugsdiagnose, som har haft kontakt med sekundær sektor pr. 100.000 indbyggere pr. år (Samlet) (ICD-10: F10-F19) (aldersgrupper: 18-24)

Antal diagnosticerede patienter med skizofreni med misbrugsdiagnose, som har haft kontakt med sekundær sektor pr. 100.000 indbyggere pr. år (Samlet) (ICD-10: F10-F19) (aldersgrupper: 25-44)

Antal diagnosticerede patienter med skizofreni med misbrugsdiagnose, som har haft kontakt med sekundær sektor pr. 100.000 indbyggere pr. år (Samlet) (ICD-10: F10-F19) (aldersgrupper: 45-64)

Antal diagnosticerede patienter med skizofreni med misbrugsdiagnose, som har haft kontakt med sekundær sektor pr. 100.000 indbyggere pr. år (Samlet) (ICD-10: F10-F19) (aldersgrupper: 65-84)

Antal diagnosticerede patienter med skizofreni med misbrugsdiagnose, som har haft kontakt med sekundær sektor pr. 100.000 indbyggere pr. år (Samlet) (ICD-10: F10-F19) (aldersgrupper: 85+)

Antal diagnosticerede patienter med skizofreni med misbrugsdiagnose, som har haft kontakt med sekundær sektor pr. 100.000 indbyggere pr. år (Mænd) (ICD-10: F10-F19)

Antal diagnosticerede patienter med skizofreni med misbrugsdiagnose, som har haft kontakt med sekundær sektor pr. 100.000 indbyggere pr. år (Mænd) (ICD-10: F10-F19) (aldersgrupper: 18-24)

Antal diagnosticerede patienter med skizofreni med misbrugsdiagnose, som har haft kontakt med sekundær sektor pr. 100.000 indbyggere pr. år (Mænd) (ICD-10: F10-F19) (aldersgrupper: 25-44)

Antal diagnosticerede patienter med skizofreni med misbrugsdiagnose, som har haft kontakt med sekundær sektor pr. 100.000 indbyggere pr. år (Mænd) (ICD-10: F10-F19) (aldersgrupper: 45-64)

Antal diagnosticerede patienter med skizofreni med misbrugsdiagnose, som har haft kontakt med sekundær sektor pr. 100.000 indbyggere pr. år (Mænd) (ICD-10: F10-F19) (aldersgrupper: 65-84)

Antal diagnosticerede patienter med skizofreni med misbrugsdiagnose, som har haft kontakt med sekundær sektor pr. 100.000 indbyggere pr. år (Mænd) (ICD-10: F10-F19) (aldersgrupper: 85+)

Antal diagnosticerede patienter med skizofreni med misbrugsdiagnose, som har haft kontakt med sekundær sektor pr. 100.000 indbyggere pr. år (Kvinder) (ICD-10: F10-F19)

Antal diagnosticerede patienter med skizofreni med misbrugsdiagnose, som har haft kontakt med sekundær sektor pr. 100.000 indbyggere pr. år (Kvinder) (ICD-10: F10-F19) (aldersgrupper: 18-24)

Antal diagnosticerede patienter med skizofreni med misbrugsdiagnose, som har haft kontakt med sekundær sektor pr. 100.000 indbyggere pr. år (Kvinder) (ICD-10: F10-F19) (aldersgrupper: 25-44)

Antal diagnosticerede patienter med skizofreni med misbrugsdiagnose, som har haft kontakt med sekundær sektor pr. 100.000 indbyggere pr. år (Kvinder) (ICD-10: F10-F19) (aldersgrupper: 45-64)

Antal diagnosticerede patienter med skizofreni med misbrugsdiagnose, som har haft kontakt med sekundær sektor pr. 100.000 indbyggere pr. år (Kvinder) (ICD-10: F10-F19) (aldersgrupper: 65-84)

Antal diagnosticerede patienter med skizofreni med misbrugsdiagnose, som har haft kontakt med sekundær sektor pr. 100.000 indbyggere pr. år (Kvinder) (ICD-10: F10-F19) (aldersgrupper: 85+)

Andel självmord inom ett år för patienter med kontakt med psykiatrin for schizofreni. Samtliga patienter som vårdats inom specialiserad psykiatrisk vård (som inlagd eller med läkarbesök i öppen vård) under ett kalenderår (räknat från första besöksdatum för året eller första inläggningsdagen vid första inskrivningen).

Antallet af dødsfald pr. 10.000 indbyggere med skizofreni der på et eller andet tidspunkt indenfor de sidste 5 år er blevet behandlet for skizofreni (20-59 år) (døde personer med skizofreni pr. 10.000 skizofrenipatienter i alt) Antallet af dødsfald i befolkningen pr. 10.000 indbyggere (20-59 år) 


\section{Kvalitetsindikatorer}

Eksisterer der nationalt klinisk kvalitetsregister på området?

Eksisterer der nationale kliniske retningslinjer (clinical practice guidelines) på området?

Uplanlagt skizofreni (alle hospitaler) genindlæggelsesrate

Uplanlagt skizofreni (samme hospital) genindlæggelsesrate

Andelen af incidente patienter med skizofreni, der udredes for psykopatologi ved speciallæge

Andelen af incidente patienter med skizofreni, der udredes for psykopatologi og interviewes med diagnostisk

instrument (SAN, PSE, OPCRIT, SCID)

Andelen af incidente patienter med skizofreni, der udredes for kognitiv funktion ved psykolog

Andelen af incidente patienter med skizofreni, der udredes for sociale støttebehov ved socialrådgiver

Andelen af incidente patienter med skizofreni, der udredes for varighed af ubehandlet psykose og som er $\mathrm{i}$

behandling indenfor 6 måneder efter symptomdebut

Andelen af ambulante patienter med skizofreni, som har tilknyttet et fast medlem af behandlerteamet og/eller

har fået iværksat et psykoterapeutisk behandlingsforløb

Andelen af patienter med skizofreni, som får ordineret antipsykotisk behandling

Andelen af ambulante patienter med skizofreni, som får mere end ét antipsykotikum ved årsstatus

Andelen af ambulante patienter med skizofreni, som får benzodiazepiner eksklusiv benzodiazepinlignende

midler (zolpidem, zopiclon, zaleplon) ved årsstatus

Andelen af indlagte patienter med skizofreni, der får vurderet selvmordsrisiko, dokumenteret i journalen, ved udskrivelsen

Andelen af patienter med skizofreni, der modtager psykiatrisk efterbehandling ved udskrivelsen

Andel voksne med diagnosen schizofreni som har fået individuel koordineringsplan (F 20x i ICD-10)

Andel af indlagte og ambulante patienter med skizofreni og pårørende, der får tilbudt psykoedukativ familiein-

tervention

Genindlæggelse på psykiatrisk afdeling for skizofreni (14 til 28 dage)

Genindlæggelse på psykiatrisk afdeling for skizofreni ( 3 til 6 måneder)

Andelen af patienter med skizofreni, som har neurologiske bivirkninge

Andelen af patienter med skizofreni, som har $\varsigma \varnothing \mathrm{vn}$ - og sedationsbivirkninger

Andelen af patienter med skizofreni, som har haft vægtøgning

Andelen af patienter med skizofreni, som har seksuelle bivirkninger

Andelen af patienter med skizofreni, som har forhøjet BMI

Andelen af patienter med skizofreni, som har forøget taljeomfang

Andelen af patienter med skizofreni, som har forhøjet blodsukker

Andelen af patienter med skizofreni, som har dyslipidæmi

Andelen af patienter med skizofreni, som har forhøjet blodtryk

Undvikbar somatisk slutenvård efter vård inom psykiatrin (F 20X ICD-10)

Varighed av ubehandlet psykose (VUP( i antall uker ved første episode ikke-affektiv psykose (F 20X ICD-10)

\section{ADHD ICD-10 kode: F90 og F98.8}

\section{Basisindikatore}

Antal nydiagnosticerede patienter med ADHD der har haft kontakt til sekundær sektor pr. 100.000 indbyggere pr. år (Samlet)

Antal nydiagnosticerede patienter med ADHD der har haft kontakt til sekundær sektor pr. år (Samlet)

Antal nydiagnosticerede patienter med ADHD der har haft kontakt til sekundær sektor pr. 100.000 indbyggere

pr. år (Drenge)

Antal nydiagnosticerede patienter med ADHD der har haft kontakt til sekundær sektor pr. år (Drenge)

Antal nydiagnosticerede patienter med ADHD der har haft kontakt til sekundær sektor pr. 100.000 indbyggere pr. år (Piger)

Antal nydiagnosticerede patienter med ADHD der har haft kontakt til sekundær sektor pr. år (Piger)

Antal nydiagnosticerede patienter med ADHD og misbrugsdiagnose der har haft kontakt til sekundær sektor pr.

100.000 indbyggere pr. år (Samlet) (ICD-10: F10-F19)

Antal nydiagnosticerede patienter med ADHD og misbrugsdiagnose der har haft kontakt til sekundær sektor pr. år (Samlet) (ICD-10: F10-F19)

Antal nydiagnosticerede patienter med ADHD og misbrugsdiagnose der har haft kontakt til sekundær sektor pr. 100.000 indbyggere pr. år (Drenge) (ICD-10: F10-F19)

Antal nydiagnosticerede patienter med ADHD og misbrugsdiagnose der har haft kontakt til sekundær sektor pr. år (Drenge) (ICD-10: F10-F19)

Antal nydiagnosticerede patienter med ADHD og misbrugsdiagnose der har haft kontakt til sekundær sektor pr. 100.000 indbyggere pr. år (Piger) (ICD-10: F10-F19)

Antal nydiagnosticerede patienter med ADHD og misbrugsdiagnose der har haft kontakt til sekundær sektor pr. år (Piger) (ICD-10: F10-F19)

Antal diagnosticerede patienter med ADHD, som har haft kontakt med sekundær sektor pr. 100.000 indbyggere pr. år (Samlet)

Antal diagnosticerede patienter med ADHD, som har haft kontakt med sekundær sektor pr. 100.000 indbyggere pr. år (Samlet) (aldersgrupper: 0-5)

Antal diagnosticerede patienter med ADHD, som har haft kontakt med sekundær sektor pr. 100.000 indbyggere pr. år (Samlet) (aldersgrupper: 6-17) 
Antal diagnosticerede patienter med ADHD, som har haft kontakt med sekundær sektor pr. 100.000 indbyggere pr. år (Samlet) (aldersgrupper: 18-24)

Antal diagnosticerede patienter med ADHD, som har haft kontakt med sekundær sektor pr. 100.000 indbyggere pr. år (Samlet) (aldersgrupper: 25+)

Antal diagnosticerede patienter med ADHD, som har haft kontakt med sekundær sektor pr. 100.000 indbyggere pr. år (Drenge/mænd)

Antal diagnosticerede patienter med ADHD, som har haft kontakt med sekundær sektor pr. 100.000 indbyggere pr. år (Drenge/mænd) (aldersgrupper: 0-5)

Antal diagnosticerede patienter med ADHD, som har haft kontakt med sekundær sektor pr. 100.000 indbyggere

pr. år (Drenge/mænd) (aldersgrupper: 6-17)

Antal diagnosticerede patienter med ADHD, som har haft kontakt med sekundær sektor pr. 100.000 indbyggere pr. år (Drenge/mænd) (aldersgrupper: 18-24)

Antal diagnosticerede patienter med ADHD, som har haft kontakt med sekundær sektor pr. 100.000 indbyggere pr. år (Drenge/mænd) (aldersgrupper: $25+$ )

Antal diagnosticerede patienter med ADHD, som har haft kontakt med sekundær sektor pr. 100.000 indbyggere pr. år (Piger/kvinder)

Antal diagnosticerede patienter med ADHD, som har haft kontakt med sekundær sektor pr. 100.000 indbyggere pr. år (Piger/kvinder) (aldersgrupper: 0-5)

Antal diagnosticerede patienter med ADHD, som har haft kontakt med sekundær sektor pr. 100.000 indbyggere pr. år (Piger/kvinder) (aldersgrupper: 6-17)

Antal diagnosticerede patienter med ADHD, som har haft kontakt med sekundær sektor pr. 100.000 indbyggere pr. år (Piger/kvinder) (aldersgrupper: 18-24)

Antal diagnosticerede patienter med ADHD, som har haft kontakt med sekundær sektor pr. 100.000 indbyggere pr. år (Piger/kvinder) (aldersgrupper: 25+)

Antal diagnosticerede patienter med ADHD med misbrugsdiagnose, som har haft kontakt med sekundær sektor pr. 100.000 indbyggere pr. år (Samlet) (ICD-10: F10-F19)

Antal diagnosticerede patienter med ADHD med misbrugsdiagnose, som har haft kontakt med sekundær sektor pr. 100.000 indbyggere pr. år (Samlet) (ICD-10: F10-F19) (aldersgrupper: 0-5)

Antal diagnosticerede patienter med ADHD med misbrugsdiagnose, som har haft kontakt med sekundær sektor pr. 100.000 indbyggere pr. år (Samlet) (ICD-10: F10-F19) (aldersgrupper: 6-17)

Antal diagnosticerede patienter med ADHD med misbrugsdiagnose, som har haft kontakt med sekundær sektor pr. 100.000 indbyggere pr. år (Samlet) (ICD-10: F10-F19) (aldersgrupper: 18-24)

Antal diagnosticerede patienter med ADHD med misbrugsdiagnose, som har haft kontakt med sekundær sektor pr. 100.000 indbyggere pr. år (Samlet) (ICD-10: F10-F19) (aldersgrupper: 25+)

Antal diagnosticerede patienter med ADHD med misbrugsdiagnose, som har haft kontakt med sekundær sektor pr. 100.000 indbyggere pr. år (Drenge/mænd) (ICD-10: F10-F19)

Antal diagnosticerede patienter med ADHD med misbrugsdiagnose, som har haft kontakt med sekundær sektor pr. 100.000 indbyggere pr. år (Drenge/mænd) (ICD-10: F10-F19) (aldersgrupper: 0-5)

Antal diagnosticerede patienter med ADHD med misbrugsdiagnose, som har haft kontakt med sekundær sektor pr. 100.000 indbyggere pr. år (Drenge/mænd) (ICD-10: F10-F19) (aldersgrupper: 6-17)

Antal diagnosticerede patienter med ADHD med misbrugsdiagnose, som har haft kontakt med sekundær sektor pr. 100.000 indbyggere pr. år (Drenge/mænd) (ICD-10: F10-F19) (aldersgrupper: 18-24)

Antal diagnosticerede patienter med ADHD med misbrugsdiagnose, som har haft kontakt med sekundær sektor pr. 100.000 indbyggere pr. år (Drenge/mænd) (ICD-10: F10-F19) (aldersgrupper: 25+)

Antal diagnosticerede patienter med ADHD med misbrugsdiagnose, som har haft kontakt med sekundær sektor pr. 100.000 indbyggere pr. år (Piger/kvinder) (ICD-10: F10-F19)

Antal diagnosticerede patienter med ADHD med misbrugsdiagnose, som har haft kontakt med sekundær sektor pr. 100.000 indbyggere pr. år (Piger/kvinder) (ICD-10: F10-F19) (aldersgrupper: 0-5)

Antal diagnosticerede patienter med ADHD med misbrugsdiagnose, som har haft kontakt med sekundær sektor pr. 100.000 indbyggere pr. år (Piger/kvinder) (ICD-10: F10-F19) (aldersgrupper: 6-17)

Antal diagnosticerede patienter med ADHD med misbrugsdiagnose, som har haft kontakt med sekundær sektor pr. 100.000 indbyggere pr. år (Piger/kvinder) (ICD-10: F10-F19) (aldersgrupper: 18-24)

Antal diagnosticerede patienter med ADHD med misbrugsdiagnose, som har haft kontakt med sekundær sektor pr. 100.000 indbyggere pr. år (Piger/kvinder) (ICD-10: F10-F19) (aldersgrupper: 25+)

Antal patientforløb med ADHD

Andel självmord inom ett år för patienter med kontakt med psykiatrin for ADHD. Samtliga patienter som vårdats inom specialiserad psykiatrisk vård (som inlagd eller med läkarbesök i öppen vård) under ett kalenderår (räknat från första besöksdatum för året eller första inläggningsdagen vid första inskrivningen).

Kvalitetsindikatorer

Eksisterer der nationalt klinisk kvalitetsregister på området?

Eksisterer der kliniske retningslinjer (clinical practice guidelines) på området?

ADHD-RS Andel af behandlingsforløb med ADHD diagnose hvor ADHD-RS score normaliseres 
Bipolar lidelse ICD-10 kode: F30-F31

Basisindikatorer

Antal nydiagnosticerede patienter med bipolar lidelse med kontakt til sekundær sektor pr. 100.000 indbyggere pr. år (Samlet)

Antal nydiagnosticerede patienter med bipolar lidelse med kontakt til sekundær sektor pr. år (Samlet)

Antal nydiagnosticerede patienter med bipolar lidelse med kontakt til sekundær sektor pr. 100.000 indbyggere pr. år (Mænd)

Antal nydiagnosticerede patienter med bipolar lidelse med kontakt til sekundær sektor pr. år (Mænd)

Antal nydiagnosticerede patienter med bipolar lidelse med kontakt til sekundær sektor pr. 100.000 indbyggere

pr. år (Kvinder)

Antal nydiagnosticerede patienter med bipolar lidelse med kontakt til sekundær sektor pr. år (Kvinder)

Antal nydiagnosticerede patienter med bipolar lidelse og misbrugsdiagnose med kontakt til sekundær sektor pr. 100.000 indbyggere pr. år (Samlet) (ICD-10: F10-F19)

Antal nydiagnosticerede patienter med bipolar lidelse og misbrugsdiagnose med kontakt til sekundær sektor pr. år (Samlet) (ICD-10: F10-F19)

Antal nydiagnosticerede patienter med bipolar lidelse og misbrugsdiagnose med kontakt til sekundær sektor pr. 100.000 indbyggere pr. år (Mænd) (ICD-10: F10-F19)

Antal nydiagnosticerede patienter med bipolar lidelse og misbrugsdiagnose med kontakt til sekundær sektor pr. år (Mænd) (ICD-10: F10-F19)

Antal nydiagnosticerede patienter med bipolar lidelse og misbrugsdiagnose med kontakt til sekundær sektor pr. 100.000 indbyggere pr. år (Kvinder) (ICD-10: F10-F19)

Antal nydiagnosticerede patienter med bipolar lidelse og misbrugsdiagnose med kontakt til sekundær sektor pr. år (Kvinder) (ICD-10: F10-F19)

Antal diagnosticerede patienter med bipolar lidelse, som har haft kontakt med sekundær sektor pr. 100.000 indbyggere pr. år (Samlet)

Antal diagnosticerede patienter med bipolar lidelse, som har haft kontakt med sekundær sektor pr. 100.000 indbyggere pr. år (Samlet) (aldersgrupper: 18-24

Antal diagnosticerede patienter med bipolar lidelse, som har haft kontakt med sekundær sektor pr. 100.000 indbyggere pr. år (Samlet) (aldersgrupper: 25-44)

Antal diagnosticerede patienter med bipolar lidelse, som har haft kontakt med sekundær sektor pr. 100.000 indbyggere pr. år (Samlet) (aldersgrupper: 45-64)

Antal diagnosticerede patienter med bipolar lidelse, som har haft kontakt med sekundær sektor pr. 100.000 indbyggere pr. år (Samlet) (aldersgrupper: 65-84)

Antal diagnosticerede patienter med bipolar lidelse, som har haft kontakt med sekundær sektor pr. 100.000 indbyggere pr. år (Samlet) (aldersgrupper: $85+$ )

Antal diagnosticerede patienter med bipolar lidelse, som har haft kontakt med sekundær sektor pr. 100.000 indbyggere pr. år (Mænd)

Antal diagnosticerede patienter med bipolar lidelse, som har haft kontakt med sekundær sektor pr. 100.000 indbyggere pr. år (Mænd) (aldersgrupper: 18-24)

Antal diagnosticerede patienter med bipolar lidelse, som har haft kontakt med sekundær sektor pr. 100.000 indbyggere pr. år (Mænd) (aldersgrupper: 25-44)

Antal diagnosticerede patienter med bipolar lidelse, som har haft kontakt med sekundær sektor pr. 100.000 indbyggere pr. år (Mænd) (aldersgrupper: 45-64)

Antal diagnosticerede patienter med bipolar lidelse, som har haft kontakt med sekundær sektor pr. 100.000 indbyggere pr. år (Mænd) (aldersgrupper: 65-84)

Antal diagnosticerede patienter med bipolar lidelse, som har haft kontakt med sekundær sektor pr. 100.000 indbyggere pr. år (Mænd) (aldersgrupper: $85+$ )

Antal diagnosticerede patienter med bipolar lidelse, som har haft kontakt med sekundær sektor pr. 100.000 indbyggere pr. år (Kvinder)

Antal diagnosticerede patienter med bipolar lidelse, som har haft kontakt med sekundær sektor pr. 100.000 indbyggere pr. år (Kvinder) (aldersgrupper: 18-24)

Antal diagnosticerede patienter med bipolar lidelse, som har haft kontakt med sekundær sektor pr. 100.000 indbyggere pr. år (Kvinder) (aldersgrupper: 25-44)

Antal diagnosticerede patienter med bipolar lidelse, som har haft kontakt med sekundær sektor pr. 100.000 indbyggere pr. år (Kvinder) (aldersgrupper: 45-64)

Antal diagnosticerede patienter med bipolar lidelse, som har haft kontakt med sekundær sektor pr. 100.000 indbyggere pr. år (Kvinder) (aldersgrupper: 65-84)

Antal diagnosticerede patienter med bipolar lidelse, som har haft kontakt med sekundær sektor pr. 100.000 indbyggere pr. år (Kvinder) (aldersgrupper: $85+$ )

Antal diagnosticerede patienter med bipolar lidelse med misbrugsdiagnose, som har haft kontakt med sekundær sektor pr. 100.000 indbyggere pr. år (Samlet) (ICD-10: F10-F19)

Antal diagnosticerede patienter med bipolar lidelse med misbrugsdiagnose, som har haft kontakt med sekundær sektor pr. 100.000 indbyggere pr. år (Samlet) (ICD-10: F10-F19) (aldersgrupper: 18-24) Antal diagnosticerede patienter med bipolar lidelse med misbrugsdiagnose, som har haft kontakt med sekundær sektor pr. 100.000 indbyggere pr. år (Samlet) (ICD-10: F10-F19)(aldersgrupper: 25-44) Antal diagnosticerede patienter med bipolar lidelse med misbrugsdiagnose, som har haft kontakt med sekundær sektor pr. 100.000 indbyggere pr. år (Samlet) (ICD-10: F10-F19) (aldersgrupper: 45-64) Antal diagnosticerede patienter med bipolar lidelse med misbrugsdiagnose, som har haft kontakt med sekundær sektor pr. 100.000 indbyggere pr. år (Samlet) (ICD-10: F10-F19) (aldersgrupper: 65-84) 
Antal diagnosticerede patienter med bipolar lidelse med misbrugsdiagnose, som har haft kontakt med sekundær sektor pr. 100.000 indbyggere pr. år (Samlet) (ICD-10: F10-F19) (aldersgrupper: 85+) Antal diagnosticerede patienter med bipolar lidelse med misbrugsdiagnose, som har haft kontakt med sekundær sektor pr. 100.000 indbyggere pr. år (Mænd) (ICD-10: F10-F19)

Antal diagnosticerede patienter med bipolar lidelse med misbrugsdiagnose, som har haft kontakt med sekundær sektor pr. 100.000 indbyggere pr. år (Mænd) (ICD-10: F10-F19) (aldersgrupper: 18-24)

Antal diagnosticerede patienter med bipolar lidelse med misbrugsdiagnose, som har haft kontakt med sekundær sektor pr. 100.000 indbyggere pr. år (Mænd) (ICD-10: F10-F19) (aldersgrupper: 25-44)

Antal diagnosticerede patienter med bipolar lidelse med misbrugsdiagnose, som har haft kontakt med sekundær sektor pr. 100.000 indbyggere pr. år (Mænd) (ICD-10: F10-F19) (aldersgrupper: 45-64)

Antal diagnosticerede patienter med bipolar lidelse med misbrugsdiagnose, som har haft kontakt med sekundær sektor pr. 100.000 indbyggere pr. år (Mænd) (ICD-10: F10-F19) (aldersgrupper: 65-84)

Antal diagnosticerede patienter med bipolar lidelse med misbrugsdiagnose, som har haft kontakt med sekundær sektor pr. 100.000 indbyggere pr. år (Mænd) (ICD-10: F10-F19) (aldersgrupper: 85+)

Antal diagnosticerede patienter med bipolar lidelse med misbrugsdiagnose, som har haft kontakt med sekundær sektor pr. 100.000 indbyggere pr. år (Kvinder) (ICD-10: F10-F19)

Antal diagnosticerede patienter med bipolar lidelse med misbrugsdiagnose, som har haft kontakt med sekundær sektor pr. 100.000 indbyggere pr. år (Kvinder) (ICD-10: F10-F19) (aldersgrupper: 18-24)

Antal diagnosticerede patienter med bipolar lidelse med misbrugsdiagnose, som har haft kontakt med sekundær sektor pr. 100.000 indbyggere pr. år (Kvinder) (ICD-10: F10-F19) (aldersgrupper: 25-44)

Antal diagnosticerede patienter med bipolar lidelse med misbrugsdiagnose, som har haft kontakt med sekundær sektor pr. 100.000 indbyggere pr. år (Kvinder) (ICD-10: F10-F19) (aldersgrupper: 45-64)

Antal diagnosticerede patienter med bipolar lidelse med misbrugsdiagnose, som har haft kontakt med sekundær sektor pr. 100.000 indbyggere pr. år (Kvinder) (ICD-10: F10-F19) (aldersgrupper: 65-84)

Antal diagnosticerede patienter med bipolar lidelse med misbrugsdiagnose, som har haft kontakt med sekundær sektor pr. 100.000 indbyggere pr. år (Kvinder) (ICD-10: F10-F19) (aldersgrupper: 85+)

Andel självmord inom ett år för patienter med kontakt med psykiatrin for bipolär lidelse. Samtliga patienter som vårdats inom specialiserad psykiatrisk vård (som inlagd eller med läkarbesök i öppen vård) under ett kalenderår (räknat från första besöksdatum för året eller första inläggningsdagen vid första inskrivningen).

Kvalitetsindikatore

Eksisterer der nationalt klinisk kvalitetsregister for bipolar lidelse?

Eksisterer der kliniske retningslinjer (clinical practice guidelines) for bipolar lidelse?

Fastholdelse af litiumbehandling ved bipolar lidelse (antal personer med udtagelse af litium på recept for 1-4 måneder og 9-12 måneder i løbet af en periode i forhold til alle personer med lithium behandling i løbet af samme periode)

Antallet af dødsfald pr. 10.000 indbyggere med bipolar lidelse der på et eller andet tidspunkt indenfor de sidste 5 år er blevet behandlet for bipolar lidelse (20-59 år) (døde personer med bipolar lidelse pr. 10.000 patienter i alt med bipolar lidelse)

Antallet af dødsfald i befolkningen pr. 10.000 indbyggere (20-59 år)

Undvikbar somatisk slutenvård efter vård inom psykiatrin (F 30X-F31X ICD-10)

Genindlæggelse på psykiatrisk afdeling for bipolar lidelse (14 til 28 dage)

Genindlæggelse på psykiatrisk afdeling for bipolar lidelse ( 3 til 6 måneder)

Uplanlagt bipolar lidelse (alle sygehuse) genindlæggelsesrate

Uplanlagt bipolar lidelse (samme sygehus) genindlæggelsesrate 


\section{Depression ICD-10 kode: DF32-34.1, F06.32}

\section{Basisindikatorer}

Antal diagnosticerede patienter med depression som har haft kontakt til sekundær sektor pr. 100.000 indbyg gere pr år (Samlet)

Antal diagnosticerede patienter med depression som har haft kontakt til sekundær sektor pr. 100.000 indbyggere pr år (Samlet) (aldersgrupper: 18-24)

Antal diagnosticerede patienter med depression som har haft kontakt til sekundær sektor pr. 100.000 indbyggere pr år (Samlet) (aldersgrupper: 25-44)

Antal diagnosticerede patienter med depression som har haft kontakt til sekundær sektor pr. 100.000 indbyg gere pr år (Samlet) (aldersgrupper: 45-64)

Antal diagnosticerede patienter med depression som har haft kontakt til sekundær sektor pr. 100.000 indbyggere pr år (Samlet) (aldersgrupper: 65-84)

Antal diagnosticerede patienter med depression som har haft kontakt til sekundær sektor pr. 100.000 indbyggere pr år (Samlet) (aldersgrupper: $85+$ )

Antal diagnosticerede patienter med depression som har haft kontakt til sekundær sektor pr. 100.000 indbyggere pr år (Mænd)

Antal diagnosticerede patienter med depression som har haft kontakt til sekundær sektor pr. 100.000 indbyg gere pr år (Mænd) (aldersgrupper: 18-24)

Antal diagnosticerede patienter med depression som har haft kontakt til sekundær sektor pr. 100.000 indbyggere pr år (Mænd) (aldersgrupper: 25-44)

Antal diagnosticerede patienter med depression som har haft kontakt til sekundær sektor pr. 100.000 indbyggere pr år (Mænd) (aldersgrupper: 45-64)

Antal diagnosticerede patienter med depression som har haft kontakt til sekundær sektor pr. 100.000 indbyggere pr år (Mænd) (aldersgrupper: 65-84)

Antal diagnosticerede patienter med depression som har haft kontakt til sekundær sektor pr. 100.000 indbyggere pr år (Mænd) (aldersgrupper: 85+)

Antal diagnosticerede patienter med depression som har haft kontakt til sekundær sektor pr. 100.000 indbyggere pr år (Kvinder)

Antal diagnosticerede patienter med depression som har haft kontakt til sekundær sektor pr. 100.000 indbyggere pr år (Kvinder) (aldersgrupper: 18-24)

Antal diagnosticerede patienter med depression som har haft kontakt til sekundær sektor pr. 100.000 indbyggere pr år (Kvinder) (aldersgrupper: 25-44)

Antal diagnosticerede patienter med depression som har haft kontakt til sekundær sektor pr. 100.000 indbyggere pr år (Kvinder) (aldersgrupper: 45-64)

Antal diagnosticerede patienter med depression som har haft kontakt til sekundær sektor pr. 100.000 indbyggere pr år (Kvinder) (aldersgrupper: 65-84)

Antal diagnosticerede patienter med depression som har haft kontakt til sekundær sektor pr. 100.000 indbyg gere pr år (Kvinder) (aldersgrupper: $85+$ )

Antal diagnosticerede patienter med depression og misbrugsdiagnose som har haft kontakt til sekundær sektor pr. 100.000 indbyggere pr. år (Samlet) (ICD-10: F10-F19)

Antal diagnosticerede patienter med depression og misbrugsdiagnose som har haft kontakt til sekundær sektor pr. 100.000 indbyggere pr. år (Samlet) (ICD-10: F10-F19) (aldersgrupper: 18-24)

Antal diagnosticerede patienter med depression og misbrugsdiagnose som har haft kontakt til sekundær sektor pr. 100.000 indbyggere pr. år (Samlet) (ICD-10: F10-F19) (aldersgrupper: 25-44)

Antal diagnosticerede patienter med depression og misbrugsdiagnose som har haft kontakt til sekundær sektor pr. 100.000 indbyggere pr. år (Samlet) (ICD-10: F10-F19) (aldersgrupper: 45-64)

Antal diagnosticerede patienter med depression og misbrugsdiagnose som har haft kontakt til sekundær sektor pr. 100.000 indbyggere pr. år (Samlet) (ICD-10: F10-F19) (aldersgrupper: 65-84)

Antal diagnosticerede patienter med depression og misbrugsdiagnose som har haft kontakt til sekundær sektor pr. 100.000 indbyggere pr. år (Samlet) (ICD-10: F10-F19) (aldersgrupper: 85+)

Antal diagnosticerede patienter med depression og misbrugsdiagnose som har haft kontakt til sekundær sektor pr. 100.000 indbyggere pr. år (Mænd) (ICD-10: F10-F19)

Antal diagnosticerede patienter med depression og misbrugsdiagnose som har haft kontakt til sekundær sektor pr. 100.000 indbyggere pr. år (Mænd) (ICD-10: F10-F19) (aldersgrupper: 18-24)

Antal diagnosticerede patienter med depression og misbrugsdiagnose som har haft kontakt til sekundær sektor pr. 100.000 indbyggere pr. år (Mænd) (ICD-10: F10-F19) (aldersgrupper: 25-44)

Antal diagnosticerede patienter med depression og misbrugsdiagnose som har haft kontakt til sekundær sektor pr. 100.000 indbyggere pr. år (Mænd) (ICD-10: F10-F19) (aldersgrupper: 45-64)

Antal diagnosticerede patienter med depression og misbrugsdiagnose som har haft kontakt til sekun dær sektor pr. 100.000 indbyggere pr. år (Mænd) (ICD-10: F10-F19) (aldersgrupper: 65-84)

Antal diagnosticerede patienter med depression og misbrugsdiagnose som har haft kontakt til sekundær sektor pr. 100.000 indbyggere pr. år (Mænd) (ICD-10: F10-F19) (aldersgrupper: 85+)

Antal diagnosticerede patienter med depression og misbrugsdiagnose som har haft kontakt til sekundær sektor pr. 100.000 indbyggere pr. år (Kvinder) (ICD-10: F10-F19)

Antal diagnosticerede patienter med depression og misbrugsdiagnose som har haft kontakt til sekundær sektor pr. 100.000 indbyggere pr. år (Kvinder) (ICD-10: F10-F19) (aldersgrupper: 18-24)

Antal diagnosticerede patienter med depression og misbrugsdiagnose som har haft kontakt til sekundær sektor pr. 100.000 indbyggere pr. år (Kvinder) (ICD-10: F10-F19) (aldersgrupper: 25-44)

Antal diagnosticerede patienter med depression og misbrugsdiagnose som har haft kontakt til sekundær sektor 
pr. 100.000 indbyggere pr. år (Kvinder) (ICD-10: F10-F19) (aldersgrupper: 45-64)

Antal diagnosticerede patienter med depression og misbrugsdiagnose som har haft kontakt til sekundær sektor pr. 100.000 indbyggere pr. år (Kvinder) (ICD-10: F10-F19) (aldersgrupper: 65-84)

Antal diagnosticerede patienter med depression og misbrugsdiagnose som har haft kontakt til sekundær sektor pr. 100.000 indbyggere pr. år (Kvinder) (ICD-10: F10-F19) (aldersgrupper: 85+)

Andelen af indlagte patienter, der $\mathrm{d} \emptyset \mathrm{r}$ inden for 30 dage efter udskrivelse fra psykiatrisk afdeling

Andelen af indlagte patienter, der $\mathrm{d} \emptyset \mathrm{r}$ inden for 60 dage efter udskrivelse fra psykiatrisk afdeling

Andelen af indlagte patienter, der dør inden for 90 dage efter udskrivelse fra psykiatrisk afdeling

Andel självmord inom ett år för patienter med kontakt med psykiatrin for depression. Samtliga patienter som

vårdats inom specialiserad psykiatrisk vård (som inlagd eller med läkarbesök i öppen vård) under ett kalenderår (räknat från första besöksdatum för året eller första inläggningsdagen vid första inskrivningen).

Antal patienter med depression der har fået behandling med elektroshock ECT i forhold til antal patienter i alt med depression (kode BRXA1) (moderat til svær, svær)

Andelen personer med svår til mycket svår egentlig depressionsepisod som fått ECT behandling under de

senaste 12 månaderna

Kvalitetsindikatorer

Eksisterer der nationalt klinisk kvalitetsregister på området?

Eksisterer der nationale kliniske retningslinjer (clinical practice guidelines) på området?

Andelen af indlagte patienter, som får vurderet depressionssværhedsgraden ved Hamiltons Depressionsskala

(HAM-D17) inden for 7 dage fra indlæggelsesdatoen på psykiatrisk afdeling

Andelen af indlagte patienter der har fået vurderet depressionssværhedsgraden ved hamiltons Depresionsskala

(HAM-D17) ved udskrivelse fra psykiatrisk afdeling

Andelen af indlagte patienter, med depression der vurderes ved speciallæge i psykiatri inden for 7 dage efter

indlæggelsesdatoen på psykiatrisk afdeling

Andelen af indlagte patienter med depression, hvor der er foretaget initial somatisk udredning inden for 2 dage

fra indlæggelsesdatoen

Andel af indlagte patienter med depression, der er undersøgt for selvmordsrisiko ved indlæggelse på psykiatrisk afdeling

Andelen af indlagte patienter med depression hvor patienten vurderes vedr. sociale st $\varnothing$ ttebehov senest ved udskrivelse fra psykiatrisk afdeling

Andelen af indlagte patienter med depression, hvor pårørende tilbydes kontakt med henblik på inddragelse senest ved udskrivelse fra psykiatrisk afdeling

Andelen af indlagte patienter med depression, hvor der er aftalt planlagt opfølgning ved udskrivelse fra psykiatrisk afdeling.

Andelen af ambulante patienter med depression, der vurderes ved speciallæge i psykiatri senest 30 dage efter

1. ambulante kontakt

Andelen af ambulante patienter med depression, der er undersøgt for selvmordsrisiko ved 1. ambulante

kontakt

Andelen af ambulante patienter med depression, hvor patienten udredes for sociale støttebehov senest ved afslutning af ambulant forløb

Andelen af ambulante patienter depression, hvor pårørende tilbydes kontakt med henblik på inddragelse senest 90 dage efter 1 . ambulante kontakt

Andelen af ambulante patienter, som får vurderet depressionssværhedsgraden ved valideret skala senest 30 dage efter 1. ambulante bes $\varnothing \mathrm{g}$

Andelen af ambulante patienter der har fået vurderet depressionssværhedsgraden ved valideret skala ved afslutning af ambulant forløb

Genindlæggelse på psykiatrisk afdeling for depressionssygdom (14 til 28 dage)

Genindlæggelse på psykiatrisk afdeling for depressionssygdom (3 til 6 måneder)

Undvikbar somatisk slutenvård efter vård inom psykiatrin (ICD-10: F32-34.1, F06.32F)

Följsamhet till behandling med antidepressiva läkemedel. Antal personer 18 år och äldre på antidepressiv medicinering som hämtat ut ytterligare ett recept på antidepressiva 60 til 150 dagar efter det första uttaget. Antallet af dødsfald pr. 10.000 indbyggere med depression der på et eller andet tidspunkt indenfor de sidste 5 år er blevet behandlet for depression (20-59 år) (døde personer med depression pr. 10.000 depressionspatienter $\mathrm{i}$ alt)

Antallet af dødsfald i befolkningen pr. 10.000 indbyggere (20-59 år) 
Børne- og ungdomsskizofreni ICD-10 kode: F20-29 (alder 0-17 år)

Basisindikatorer

Antal diagnosticerede patienter med skizofreni, som har haft kontakt med sekundær sektor pr. 100.000 indbyggere pr. år (Samlet)

Andel självmord inom ett år för patienter med kontakt med psykiatrin for schizofreni. Samtliga patienter som vårdats inom specialiserad psykiatrisk vård (som inlagd eller med läkarbesök i öppen vård) under ett kalenderår (räknat från första besöksdatum för året eller första inläggningsdagen vid första inskrivningen).

Kvalitetsindikatore

Eksisterer der nationalt klinisk kvalitetsregister på området?

Eksisterer der kliniske retningslinjer (clinical practice guidelines) på området?

Uplanlagt skizofreni (alle sygehuse) genindlæggelsesrate

Uplanlagt skizofreni (samme sygehus) genindlæggelsesrate

Andelen af incidente patienter med skizofreni, der udredes for psykopatologi ved speciallæge

Andelen af incidente patienter med skizofreni, der udredes for psykopatologi og interviewes med diagnostisk

instrument (SCAN, PSE, OPCRIT, SCID)

Andelen af incidente patienter med skizofreni, der udredes for kognitiv funktion ved psykolog

Andelen af incidente patienter med skizofreni, der udredes for sociale støttebehov ved socialrådgiver

Andelen af incidente patienter med skizofreni, der udredes for varighed af ubehandlet psykose og som er $i$

behandling indenfor 6 måneder efter symptomdebut

Andelen af ambulante patienter med skizofreni, som har tilknyttet et fast medlem af behandlerteamet og/eller har fået iværksat et psykoterapeutisk behandlingsforløb

Andelen af patienter med skizofreni, hvor pårørende tager imod tilbudet om kontakt

Andelen af incidente patienter med skizofreni, der indenfor 1 år, modtager psykoedukation i manualiserede

forløb

Andelen af indlagte patienter med skizofreni, der får vurderet selvmordsrisiko, dokumenteret i journalen, ved udskrivelsen

Andelen af patienter med skizofreni, som får ordineret antipsykotisk behandling

Andelen af ambulante patienter med skizofreni, som får mere end ét antipsykotikum ved årsstatus

Andelen af ambulante patienter med skizofreni, som får benzodiazepiner eksklusiv benzodiazepinlignende midler (zolpidem, zopiclon, zaleplon) ved årsstatus

Andelen af patienter med skizofreni, med GAPD funktionsscore $>=5$ ved udskrivelse og som udskrives med social støtteforanstaltning i bolig

Andelen af patienter med skizofreni, der modtager psykiatrisk efterbehandling ved udskrivelsen

Andelen af patienter med skizofreni, der indenfor $1 \frac{1}{2}$ år efter udskrivelsen har fået udfyldt et statusskema for

ambulante patienter

Andelen af patienter med skizofreni, som har neurologiske bivirkninger

Andelen af patienter med skizofreni, som har $\varsigma \varnothing \mathrm{vn}$ - og sedationsbivirkninger

Andelen af patienter med skizofreni, som har haft vægtøgning

Andelen af patienter med skizofreni, som har seksuelle bivirkninger

Andelen af patienter med skizofreni, som har forhøjet BMI

Andelen af patienter med skizofreni, som har forøget taljeomfang

Andelen af patienter med skizofreni, som har forhøjet blodsukker

Andelen af patienter med skizofreni, som har dyslipidæmi

Andelen af patienter med skizofreni, som har forhøjet blodtryk 
Antal psykiatriske patienter som er i behandling i sekundær sektor pr. 100.000 indbyggere (Samlet) Antal psykiatriske patienter som er i behandling i sekundær sektor pr. 100.000 indbyggere (Samlet) (alder sgrupper: 0-17)

Antal psykiatriske patienter som er i behandling i sekundær sektor pr. 100.000 indbyggere (Samlet) (aldersgrupper: 18-24)

Antal psykiatriske patienter som er i behandling i sekundær sektor pr. 100.000 indbyggere (Samlet) (aldersgrupper: $25-44)$

Antal psykiatriske patienter som er i behandling i sekundær sektor pr. 100.000 indbyggere (Samlet) (aldersgrupper: 45-64)

Antal psykiatriske patienter som er i behandling i sekundær sektor pr. 100.000 indbyggere (Samlet) (aldersgrupper: 65-84)

Antal psykiatriske patienter som er i behandling i sekundær sektor pr. 100.000 indbyggere (Samlet) (aldersgrupper: $85+$ )

Antal psykiatriske patienter som er i behandling i sekundær sektor pr. 100.000 indbyggere (Mænd)

Antal psykiatriske patienter som er i behandling i sekundær sektor pr. 100.000 indbyggere (Mænd) (aldersgrup-

per: 0-17)

Antal psykiatriske patienter som er i behandling i sekundær sektor pr. 100.000 indbyggere (Mænd) (aldersgrupper: 18-24)

Antal psykiatriske patienter som er i behandling i sekundær sektor pr. 100.000 indbyggere (Mænd) (aldersgrupper: 25-44)

Antal psykiatriske patienter som er i behandling i sekundær sektor pr. 100.000 indbyggere (Mænd) (aldersgrupper: 45-64)

Antal psykiatriske patienter som er i behandling i sekundær sektor pr. 100.000 indbyggere (Mænd) (aldersgrupper: 65-84)

Antal psykiatriske patienter som er i behandling i sekundær sektor pr. 100.000 indbyggere (Mænd) (aldersgrupper: $85+)$

Antal psykiatriske patienter som er i behandling i sekundær sektor pr. 100.000 indbyggere (Kvinder)

Antal psykiatriske patienter som er i behandling i sekundær sektor pr. 100.000 indbyggere (Kvinder) (aldersgrupper: 0-17)

Antal psykiatriske patienter som er i behandling i sekundær sektor pr. 100.000 indbyggere (Kvinder) (aldersgrupper: 18-24)

Antal psykiatriske patienter som er i behandling i sekundær sektor pr. 100.000 indbyggere (Kvinder) (aldersgrupper: 25-44)

Antal psykiatriske patienter som er i behandling i sekundær sektor pr. 100.000 indbyggere (Kvinder) (alder s-

grupper: 45-64)

Antal psykiatriske patienter som er i behandling i sekundær sektor pr. 100.000 indbyggere (Kvinder) (aldersgrupper: $65-84)$

Antal psykiatriske patienter som er i behandling i sekundær sektor pr. 100.000 indbyggere (Kvinder) (aldersgrupper: $85+$ )

Antallet af relevante fagpersoner pr. 100.000 indbyggere (psykiatere)

Antallet af relevante fagpersoner pr. 100.000 indbyggere (psykiatriske sygeplejersker)

Antallet af relevante fagpersoner pr. 100.000 indbyggere (psykologer)

Antallet af relevante fagpersoner pr. 100.000 indbyggere (børnepsykiatere)

Kvalitetsindikatore

Antal selvmord under indlæggelser på psykiatrisk sygehus eller afdeling pr. 100.000 indbyggere

Psykiatriske patienter, der er $d \varnothing$ de som følge af selvmord pr. 100.000 indbyggere indenfor 1 år (Samlet)

Psykiatriske patienter, der er døde som følge af selvmord pr. 100.000 indbyggere indenfor 1 år (Samlet) (aldersgruppe: 18-24)

Psykiatriske patienter, der er døde som følge af selvmord pr. 100.000 indbyggere indenfor 1 år (Samlet) (aldersgruppe: $25-44)$

Psykiatriske patienter, der er døde som følge af selvmord pr. 100.000 indbyggere indenfor 1 år (Samlet) (aldersgruppe: 45-64)

Psykiatriske patienter, der er døde som følge af selvmord pr. 100.000 indbyggere indenfor 1 år (Samlet) (alder sgruppe: $65-84$ )

Psykiatriske patienter, der er d $\varnothing$ de som følge af selvmord pr. 100.000 indbyggere indenfor 1 år (Samlet) (alder sgruppe: $85+)$

Psykiatriske patienter, der er døde som følge af selvmord pr. 100.000 indbyggere indenfor 1 år (Mænd)

Psykiatriske patienter, der er døde som følge af selvmord pr. 100.000 indbyggere indenfor 1 år (Mænd) (aldersgruppe: 18-24)

Psykiatriske patienter, der er døde som følge af selvmord pr. 100.000 indbyggere indenfor 1 år (Mænd) (aldersgruppe: $25-44)$

Psykiatriske patienter, der er døde som følge af selvmord pr. 100.000 indbyggere indenfor 1 år (Mænd) (aldersgruppe: 45-64)

Psykiatriske patienter, der er døde som følge af selvmord pr. 100.000 indbyggere indenfor 1 år (Mænd) (aldersgruppe: $65-84$ 
Psykiatriske patienter, der er døde som følge af selvmord pr. 100.000 indbyggere indenfor 1 år (Mænd) (aldersgruppe: $85+)$

Psykiatriske patienter, der er $\mathrm{d} \emptyset$ de som følge af selvmord pr. 100.000 indbyggere indenfor 1 år (Kvinder) Psykiatriske patienter, der er døde som følge af selvmord pr. 100.000 indbyggere indenfor 1 år (Kvinder) (aldersgruppe: 18-24)

Psykiatriske patienter, der er $\mathrm{d} \emptyset$ de som følge af selvmord pr. 100.000 indbyggere indenfor 1 år (Kvinder) (aldersgruppe: 25-44)

Psykiatriske patienter, der er $\mathrm{d} \emptyset$ de som følge af selvmord pr. 100.000 indbyggere indenfor 1 år (Kvinder) (aldersgruppe: 45-64)

Psykiatriske patienter, der er døde som følge af selvmord pr. 100.000 indbyggere indenfor 1 år (Kvinder) (aldersgruppe: 65-84)

Psykiatriske patienter, der er døde som følge af selvmord pr. 100.000 indbyggere indenfor 1 år (Kvinder) (aldersgruppe: $85+$ )

Omkostninger for specialiserede psykiatriske afdelinger pr. 100.000 inbyggere

Antallet af psykiatriske senge, pr. 100.000 indbyggere

Udskrivninger (afsluttede indlagte forløb) fra psykiatriske enheder, pr. 1.000 indbyggere

Sengedage pr. 1.000 indbyggere i psykiatriske enheder

Gennemsnitlig liggetid på psykiatriske enheder

Antallet af psykisk syge patienter der er indlagt på sygehus kontinuerligt i mere end 1 år, pr. 100.000 indbyggere Hospitalsbehandling på psykiatriske enheder (Samlet)

Hospitalsbehandling på psykiatriske enheder (Samlet) (aldersgruppe: 0-14)

Hospitalsbehandling på psykiatriske enheder (Samlet) (aldersgruppe: 15-29)

Hospitalsbehandling på psykiatriske enheder (Samlet) (aldersgruppe: 30-44)

Hospitalsbehandling på psykiatriske enheder (Samlet) (aldersgruppe: 45-64)

Hospitalsbehandling på psykiatriske enheder (Samlet) (aldersgruppe: 65-79)

Hospitalsbehandling på psykiatriske enheder (Samlet) (aldersgruppe: 80+)

Hospitalsbehandling på psykiatriske enheder (Mænd)

Hospitalsbehandling på psykiatriske enheder (Mænd) (aldersgruppe: 0-14)

Hospitalsbehandling på psykiatriske enheder (Mænd) (aldersgruppe: 15-29)

Hospitalsbehandling på psykiatriske enheder (Mænd) (aldersgruppe: 30-44)

Hospitalsbehandling på psykiatriske enheder (Mænd) (aldersgruppe: 45-64)

Hospitalsbehandling på psykiatriske enheder (Mænd) (aldersgruppe: 65-79)

Hospitalsbehandling på psykiatriske enheder (Mænd) (aldersgruppe: 80+)

Hospitalsbehandling på psykiatriske enheder (Kvinder)

Hospitalsbehandling på psykiatriske enheder (Kvinder) (aldersgruppe: 0-14)

Hospitalsbehandling på psykiatriske enheder (Kvinder) (aldersgruppe: 15-29)

Hospitalsbehandling på psykiatriske enheder (Kvinder) (aldersgruppe: 30-44)

Hospitalsbehandling på psykiatriske enheder (Kvinder) (aldersgruppe: 45-64)

Hospitalsbehandling på psykiatriske enheder (Kvinder) (aldersgruppe: 65-79)

Hospitalsbehandling på psykiatriske enheder (Kvinder) (aldersgruppe: 80+)

Behandlede patienter pr. 1.000 indbyggere på psykiatriske enheder (Samlet)

Behandlede patienter pr. 1.000 indbyggere på psykiatriske enheder (Samlet) (Diagnosegruppe (ICD-10): F10-19)

Behandlede patienter pr. 1.000 indbyggere på psykiatriske enheder (Samlet) (Diagnosegruppe (ICD-10): F20-25)

Behandlede patienter pr. 1.000 indbyggere på psykiatriske enheder (Samlet) (Diagnosegruppe (ICD-10): F28-29)

Behandlede patienter pr. 1.000 indbyggere på psykiatriske enheder (Samlet) (Diagnosegruppe (ICD-10): F30-39)

Behandlede patienter pr. 1.000 indbyggere på psykiatriske enheder (Mænd)

Behandlede patienter pr. 1.000 indbyggere på psykiatriske enheder (Mænd) (Diagnosegruppe (ICD-10): F10-19) Behandlede patienter pr. 1.000 indbyggere på psykiatriske enheder (Mænd) (Diagnosegruppe (ICD-10): F20-25) Behandlede patienter pr. 1.000 indbyggere på psykiatriske enheder (Mænd) (Diagnosegruppe (ICD-10): F28-29) Behandlede patienter pr. 1.000 indbyggere på psykiatriske enheder (Mænd) (Diagnosegruppe (ICD-10): F30-39) Behandlede patienter pr. 1.000 indbyggere på psykiatriske enheder (Kvinder)

Behandlede patienter pr. 1.000 indbyggere på psykiatriske enheder (Kvinder) (Diagnosegruppe (ICD-10): F10-19) Behandlede patienter pr. 1.000 indbyggere på psykiatriske enheder (Kvinder) (Diagnosegruppe (ICD-10): F20-25) Behandlede patienter pr. 1.000 indbyggere på psykiatriske enheder (Kvinder) (Diagnosegruppe (ICD-10): F28-29) Behandlede patienter pr. 1.000 indbyggere på psykiatriske enheder (Kvinder) (Diagnosegruppe (ICD-10): F30-39) Dödlighet bland personer som vårdats inom sluten psykiatrisk vård ( $\mathrm{i}$ relation till befolkningen totalt) Hälsopolitiskt åtgärdbar dödlighet (antalet d"dsfall i sjukdomar som bedöms kunna åtgärdas hälsopolitiskt) Sjukvårdsrelaterad åtgärdbar dödlighed (Antalet dödsfall i sjukdomar som bedöms kunna åtgärdas med medicinska insatser)

Undvikbar somatisk slutenvård efter vård inom psykiatrin (F X ICD-10) 
Generiske procesindikatorer for børn og unge til og med 17 år

Kvalitetsindikatorer

Andel patienter som er diagnostisk vurderet i forhold til klinisk psykiatrisk syndrom

Andel patienter som er diagnostisk vurderet i forhold til specifikke udviklingsforstyrrelser

Andel patienter som er diagnostisk vurderet i forhold til aktuelle vanskelige psykosociale forhold

Andel patienter som er diagnostisk vurderet i forhold til global vurdering af psykosocialt funktionsniveau (CGAS)

Andel patienter der har ventet mere end 90 dage på besøg i børne- og ungdomspsikiatri

Andel patienter med ventetid under 60 dage (ventetid fra henvisning til forvisitation eller start på undersøgelse)

Andel patienter med ventetid under 60 dage (ventetid fra henvisning til start på unders $\varnothing$ gelse)

Andel af behandlingsforløb med svag belastning ved afslutning eller efter $6 \mathrm{mdr}$.

Andel patienter der har ventet i højest 30 dage på aftale på en børne- og ungdomspsykiatri klinik

Andel af behandlingsforløb med god psykosocial funktion ved afslutning eller efter 6 . mdr. 


\section{Bilag 5. English definition - indicators}

Schizophrenia (adults)

Number of newly diagnosed hospitalized patients with schizophrenia in contact with a psychiatric unit per 100,000 inhabitants per year (Total)

Number of newly diagnosed outpatients with schizophrenia in contact with a psychiatric unit per 100,000 inhabitants per year (Total)

Number of newly diagnosed patients with schizophrenia in contact with a psychiatric unit per 100,000 inhabitants per year (Total)

Number of newly diagnosed patients with schizophrenia in contact with a psychiatric unit per year (Total) Number of newly diagnosed hospitalized patients with schizophrenia in contact with a psychiatric unit per 100,000 inhabitants per year (Men)

Number of newly diagnosed outpatients with schizophrenia in contact with a psychiatric unit per 100,000 inhabitants per year (Men)

Number of newly diagnosed patients with schizophrenia in contact with a psychiatric unit per 100,000 inhabitants per year (Men)

Number of newly diagnosed patients with schizophrenia in contact with a psychiatric unit per year (Men) Number of newly diagnosed hospitalized patients with schizophrenia in contact with a psychiatric unit per 100,000 inhabitants per year (Women)

Number of newly diagnosed outpatients with schizophrenia in contact with a psychiatric unit per 100,000 inhabitants per year (Women)

Number of newly diagnosed patients with schizophrenia in contact with a psychiatric unit per 100,000 inhabitants per year (Women)

Number of newly diagnosed patients with schizophrenia in contact with a psychiatric unit per year (Women)

Number of newly diagnosed hospitalized patients with schizophrenia and abuse diagnosis with a contact to the a psychiatric unit per 100,000 inhabitants per year (Total) (ICD-10: F10-F19)

Number of newly diagnosed outpatients with schizophrenia and abuse diagnosis with a contact to the a psychiatric unit per 100,000 inhabitants per year (Total) (ICD-10: F10-F19)

Number of newly diagnosed patients with schizophrenia and abuse diagnosis with a contact to the a psychiatric unit per 100,000 inhabitants per year (Total) (ICD-10: F10-F19)

Number of newly diagnosed patients with schizophrenia and abuse diagnosis with a contact to the a psychiatric unit per year (Total) (ICD-10: F10-F19)

Number of newly diagnosed hospitalized patients with schizophrenia and abuse diagnosis with a contact to the a psychiatric unit per 100,000 inhabitants per year (Men) (ICD-10: F10-F19)

Number of newly diagnosed outpatients with schizophrenia and abuse diagnosis with a contact to the a psychiatric unit per 100,000 inhabitants per year (Men) (ICD-10: F10-F19)

Number of newly diagnosed patients with schizophrenia and abuse diagnosis with a contact to the a psychiatric unit per 100,000 inhabitants per year (Men) (ICD-10: F10-F19)

Number of newly diagnosed patients with schizophrenia and abuse diagnosis with a contact to the a psychiatric unit per year (Men) (ICD-10: F10-F19)

Number of newly diagnosed patients with schizophrenia and abuse diagnosis with a contact to the a psychiatric unit per 100,000 inhabitants per year (Women) (ICD-10: F10-F19)

Number of newly diagnosed hospitalized patients with schizophrenia and abuse diagnosis with a contact to the a psychiatric unit per 100,000 inhabitants per year (Women) (ICD-10: F10-F19)

Number of newly diagnosed patients with schizophrenia and abuse diagnosis with a contact to the a psychiatric unit per 100,000 inhabitants per year (Women) (ICD-10: F10-F19)

Number of newly diagnosed patients with schizophrenia and abuse diagnosis with a contact to the a psychiatric unit per year (Women) (ICD-10: F10-F19)

Number of patients diagnosed with schizophrenia who have had contact with a psychiatric unit per 100,000 inhabitants per year (Total)

Number of patients diagnosed with schizophrenia who have had contact with a psychiatric unit per 100,000 inhabitants per year (Total) (age group: 18-24)

Number of patients diagnosed with schizophrenia who have had contact with a psychiatric unit per 100,000 inhabitants per year (Total) (age group: 25-44)

Number of patients diagnosed with schizophrenia who have had contact with a psychiatric unit per 100,000 inhabitants per year (Total) (age group: 45-64)

Number of patients diagnosed with schizophrenia who have had contact with a psychiatric unit per 100,000 inhabitants per year (Total) (age group: 65-84)

Number of patients diagnosed with schizophrenia who have had contact with a psychiatric unit per 100,000 inhabitants per year (Total) (age group: $85+$ ) 
Number of patients diagnosed with schizophrenia who have had contact with a psychiatric unit per 100,000 inhabitants per year (Men)

Number of patients diagnosed with schizophrenia who have had contact with a psychiatric unit per 100,000 inhabitants per year (Men) (age group: 18-24)

Number of patients diagnosed with schizophrenia who have had contact with a psychiatric unit per 100,000 inhabitants per year (Men) (age group: 25-44)

Number of patients diagnosed with schizophrenia who have had contact with a psychiatric unit per 100,000 inhabitants per year (Men) (age group: 45-64)

Number of patients diagnosed with schizophrenia who have had contact with a psychiatric unit per 100,000 inhabitants per year (Men) (age group: 65-84)

Number of patients diagnosed with schizophrenia who have had contact with a psychiatric unit per 100,000 inhabitants per year (Men) (age group: $85+$ )

Number of patients diagnosed with schizophrenia who have had contact with a psychiatric unit per 100,000 inhabitants per year (Women)

Number of patients diagnosed with schizophrenia who have had contact with a psychiatric unit per 100,000 inhabitants per year (Women) (age group: 18-24)

Number of patients diagnosed with schizophrenia who have had contact with a psychiatric unit per 100,000 inhabitants per year (Women) (age group: 25-44)

Number of patients diagnosed with schizophrenia who have had contact with a psychiatric unit per 100,000 inhabitants per year (Women) (age group: 45-64)

Number of patients diagnosed with schizophrenia who have had contact with a psychiatric unit per 100,000 inhabitants per year (Women) (age group: 65-84)

Number of patients diagnosed with schizophrenia who have had contact with a psychiatric unit per 100,000 inhabitants per year (Women) (age group: $85+$ )

Number of patients diagnosed with schizophrenia with abuse diagnosis who have had contact with a psychiatric unit per 100,000 inhabitants per year (Total) (ICD-10: F10-F19)

Number of patients diagnosed with schizophrenia with abuse diagnosis who have had contact with a psychiatric unit per 100,000 inhabitants per year (Total) (ICD-10: F10-F19) (age group: 18-24)

Number of patients diagnosed with schizophrenia with abuse diagnosis who have had contact with a psychiatric unit per 100,000 inhabitants per year (Total) (ICD-10: F10-F19) (age group: 25-44)

Number of patients diagnosed with schizophrenia with abuse diagnosis who have had contact with a psychiatric unit per 100,000 inhabitants per year (Total) (ICD-10: F10-F19) (age group: 45-64)

Number of patients diagnosed with schizophrenia with abuse diagnosis who have had contact with a psychiatric unit per 100,000 inhabitants per year (Total) (ICD-10: F10-F19) (age group: 65-84)

Number of patients diagnosed with schizophrenia with abuse diagnosis who have had contact with a psychiatric unit per 100,000 inhabitants per year (Total) (ICD-10: F10-F19) (age group: 85+)

Number of patients diagnosed with schizophrenia with abuse diagnosis who have had contact with a psychiatric unit per 100,000 inhabitants per year (Men) (ICD-10: F10-F19)

Number of patients diagnosed with schizophrenia with abuse diagnosis who have had contact with a psychiatric unit per 100,000 inhabitants per year (Men) (ICD-10: F10-F19) (age group: 18-24)

Number of patients diagnosed with schizophrenia with abuse diagnosis who have had contact with a psychiatric unit per 100,000 inhabitants per year (Men) (ICD-10: F10-F19) (age group: 25-44)

Number of patients diagnosed with schizophrenia with abuse diagnosis who have had contact with a psychiatric unit per 100,000 inhabitants per year (Men) (ICD-10: F10-F19) (age group: 45-64)

Number of patients diagnosed with schizophrenia with abuse diagnosis who have had contact with a psychiatric unit per 100,000 inhabitants per year (Men) (ICD-10: F10-F19) (age group: 65-84)

Number of patients diagnosed with schizophrenia with abuse diagnosis who have had contact with a psychiatric unit per 100,000 inhabitants per year (Men) (ICD-10: F10-F19) (age group: 85+)

Number of patients diagnosed with schizophrenia with abuse diagnosis who have had contact with a psychiatric unit per 100,000 inhabitants per year (Women) (ICD-10: F10-F19)

Number of patients diagnosed with schizophrenia with abuse diagnosis who have had contact with a psychiatric unit per 100,000 inhabitants per year (Women) (ICD-10: F10-F19) (age group: 18-24)

Number of patients diagnosed with schizophrenia with abuse diagnosis who have had contact with a psychiatric unit per 100,000 inhabitants per year (Women) (ICD-10: F10-F19) (age group: 25-44)

Number of patients diagnosed with schizophrenia with abuse diagnosis who have had contact with a psychiatric unit per 100,000 inhabitants per year (Women) (ICD-10: F10-F19) (age group: 45-64)

Number of patients diagnosed with schizophrenia with abuse diagnosis who have had contact with a psychiatric unit per 100,000 inhabitants per year (Women) (ICD-10: F10-F19) (age group: 65-84)

Number of patients diagnosed with schizophrenia with abuse diagnosis who have had contact with a psychiatric unit per 100,000 inhabitants per year (Women) (ICD-10: F10-F19) (age group: 85+)

Proportion of suicide among patient with schizophrenia who have had contact with a psychiatric unit (to count for first admissionday or first visit)

Number of deaths per 10000 residents with schizophrenia who at some time in the past five years been

treated for schizophrenia (20-59 years) (are related to all death in the population)

Number of deaths per 10000 residents (20-59 years)

Is there a national quality register for this?

Existing National clinical practice guidelines for Schizofrenia?

Unplanned schizophrenia (any hospital) re-admission rate

Unplanned schizophrenia (same hospital) re-admission rate

Proportion of incident (diagnosed within 12 months of contact) patients examined for psychopathology by a medical specialist 
Proportion of incident (diagnosed within 12 months of contact) patients examined for psychopathology by a specialist in psychiatry where the assessment is done using a diagnostic instrument (SCAN, OPCRIT, SCID) Proportion of incident (diagnosed within 12 months of contact) patients for whom cognitive function was examined by a psychologist

Proportion of incident (diagnosed within 12 months of contact) patients for which need for social support has been assessed by a medical social worker, councellor, welfare officer, not medical social worker

Proportion of incident (diagnosed within 12 months of contact) patients being assessed for duration of untreated psychosis who receive treatment within six months from first showing symptoms

Proportion of outpatients in contact with a specific member of the therapist team and/or for whom a psychotherapeutic treatment course has been initiated

Proportion of patients who have a prescription for antipsychotic medication

Proportion of outpatients receiving more than one type of antipsychotic medication at annual status

Proportion of outpatients receiving benzodiazepines exclusive of medicine similar to benzodiazepine (Zolpidem, Zopiclon, Zaleplon) at annual status

Proportion of hospitalized patients assessed for suicide risk (documented in patient record) at discharge

Proportion of patients discharged to an outpatient program

Proportion of adults diagnosed with schizophrenia who received individual coordination plane (F20x in ICD-10)

Proportion of inpatients and outpatients with schizophrenia and relatives who are offered psykoeducation

family inervention

Readmission after 14 to 28 days following in-patient treatment for schizofrenia

Readmission after 3 to 6 months following in-patient treatment for schizofrenia

Proportion of patients who have neurological side effects

Proportion of patients who have sleeping and sedation side effects

Proportion of patients who gain weight as a side effect

Proportion of patients who have sexual side effects

Proportion of patients who have an increased body mass index (BMI)

Proportion of patients who have an increased waistline measure

Proportion of patients who have an increased blood glucose level

Proportion of patients who have an increased level of blood lipids

Proportion of patients who have an increased blood pressure

Duration of Untreatet psychosis (DUP) in number of weeks in first episode non-affective psychossis (F20-29 ICD10)

ADHD

Number of newly diagnosed patients with ADHD who have had contact with a psychiatric unit per 100,000 inhabitants per year (Total)

Number of newly diagnosed patients with ADHD who have had contact with a psychiatric unit inhabitants per year (Total)

Number of newly diagnosed patients with ADHD who have had contact with a psychiatric unit per 100,000

inhabitants per year (Boys)

Number of newly diagnosed patients with ADHD who have had contact with a psychiatric unit per year (Boys)

Number of newly diagnosed patients with ADHD who have had contact with a psychiatric unit per 100,000

inhabitants per year (Girls)

Number of newly diagnosed patients with ADHD who have had contact with a psychiatric unit per year (Girls)

Number of newly diagnosed patients with ADHD and abuse diagnosis who have had contact with a psychiatric unit per 100,000 inhabitants per year (Total) (ICD-10: F10-F19)

Number of newly diagnosed patients with ADHD and abuse diagnosis who have had contact with a psychiatric unit per year (Total) (ICD-10: F10-F19)

Number of newly diagnosed patients with ADHD and abuse diagnosis who have had contact with a psychiatric unit per 100,000 inhabitants per year (Boys) (ICD-10: F10-F19)

Number of newly diagnosed patients with ADHD and abuse diagnosis who have had contact with a psychiatric unit per year (Boys) (ICD-10: F10-F19)

Number of newly diagnosed patients with ADHD and abuse diagnosis who have had contact with a psychiatric unit per 100,000 inhabitants per year (Girls) (ICD-10: F10-F19)

Number of newly diagnosed patients with ADHD and abuse diagnosis who have had contact with a psychiatric unit per year (Girls) (ICD-10: F10-F19)

Number of patients diagnosed with ADHD who have had contact with a psychiatric unit per 100,000 inhabitants per year (Total)

Number of patients diagnosed with ADHD who have had contact with a psychiatric unit per 100,000 inhabitants per year (Total) (age group: 0-5)

Number of patients diagnosed with ADHD who have had contact with a psychiatric unit per 100,000 inhabitants per year (Total) (age group: 6-17)

Number of patients diagnosed with ADHD who have had contact with a psychiatric unit per 100,000 inhabitants per year (Total) (age group: 18-24)

Number of patients diagnosed with ADHD who have had contact with a psychiatric unit per 100,000 inhabitants per year (Total) (age group: $25+$ )

Number of patients diagnosed with ADHD who have had contact with a psychiatric unit per 100,000 inhabitants per year (Boys/Men)

Number of patients diagnosed with ADHD who have had contact with a psychiatric unit per 100,000 inhabitants per year (Boys/Men) (age group: 0-5)

Number of patients diagnosed with ADHD who have had contact with a psychiatric unit per 100,000 inhabitants per year (Boys/Men) (age group: 6-17) 
Number of patients diagnosed with ADHD who have had contact with a psychiatric unit per 100,000 inhabitants per year (Boys/Men) (age group: 18-24)

Number of patients diagnosed with ADHD who have had contact with a psychiatric unit per 100,000 inhabitants per year (Boys/Men) (age group: 25+)

Number of patients diagnosed with ADHD who have had contact with a psychiatric unit per 100,000 inhabitants per year (Girls/Women)

Number of patients diagnosed with ADHD who have had contact with a psychiatric unit per 100,000 inhabitants per year (Girls/Women) (age group: 0-5)

Number of patients diagnosed with ADHD who have had contact with a psychiatric unit per 100,000 inhabitants per year (Girls/Women) (age group: 6-17)

Number of patients diagnosed with ADHD who have had contact with a psychiatric unit per 100,000 inhabitants per year (Girls/Women) (age group: 18-24)

Number of patients diagnosed with ADHD who have had contact with a psychiatric unit per 100,000 inhabitants per year (Girls/Women) (age group: 25+)

Number of patients diagnosed with ADHD and abuse diagnosis who have had contact with a psychiatric unit per 100,000 inhabitants per year (Total) (ICD-10: F10-F19)

Number of patients diagnosed with ADHD and abuse diagnosis who have had contact with a psychiatric unit per 100,000 inhabitants per year (Total) (ICD-10: F10-F19) (age group: 0-5)

Number of patients diagnosed with ADHD and abuse diagnosis who have had contact with a psychiatric unit per 100,000 inhabitants per year (Total) (ICD-10: F10-F19) (age group: 6-17)

Number of patients diagnosed with ADHD and abuse diagnosis who have had contact with a psychiatric unit per 100,000 inhabitants per year (Total) (ICD-10: F10-F19) (age group: 18-24)

Number of patients diagnosed with ADHD and abuse diagnosis who have had contact with a psychiatric unit per 100,000 inhabitants per year (Total) (ICD-10: F10-F19) (age group: 25+)

Number of patients diagnosed with ADHD and abuse diagnosis who have had contact with a psychiatric unit per 100,000 inhabitants per year (Boys/Men) (ICD-10: F10-F19)

Number of patients diagnosed with ADHD and abuse diagnosis who have had contact with a psychiatric unit per 100,000 inhabitants per year (Boys/Men) (ICD-10: F10-F19) (age group: 0-5)

Number of patients diagnosed with ADHD and abuse diagnosis who have had contact with a psychiatric unit per 100,000 inhabitants per year (Boys/Men) (ICD-10: F10-F19) (age group: 6-17)

Number of patients diagnosed with ADHD and abuse diagnosis who have had contact with a psychiatric unit per 100,000 inhabitants per year (Boys/Men) (ICD-10: F10-F19) (age group: 18-24)

Number of patients diagnosed with ADHD and abuse diagnosis who have had contact with a psychiatric unit per 100,000 inhabitants per year (Boys/Men) (ICD-10: F10-F19) (age group: 25+)

Number of patients diagnosed with ADHD and abuse diagnosis who have had contact with a psychiatric unit per 100,000 inhabitants per year (Girls/Women) (ICD-10: F10-F19)

Number of patients diagnosed with ADHD and abuse diagnosis who have had contact with a psychiatric unit per 100,000 inhabitants per year (Girls/Women) (ICD-10: F10-F19) (age group: 0-5)

Number of patients diagnosed with ADHD and abuse diagnosis who have had contact with a psychiatric unit per 100,000 inhabitants per year (Girls/Women) (ICD-10: F10-F19) (age group: 6-17)

Number of patients diagnosed with ADHD and abuse diagnosis who have had contact with a psychiatric unit per 100,000 inhabitants per year (Girls/Women) (ICD-10: F10-F19) (age group: 18-24)

Number of patients diagnosed with ADHD and abuse diagnosis who have had contact with a psychiatric unit per 100,000 inhabitants per year (Girls/Women) (ICD-10: F10-F19) (age group: 25+)

Number of Patient pathways with ADHD

Is there a National Quality Register for this?

Existing National clinical practice guidelines for ADHD?

Bipolar

Number of newly diagnosed patients with bipolar disorder who have had a contact with a psychiatric unit per 100,000 inhabitants per year (Total)

Number of newly diagnosed patients with bipolar disorder who have had a contact with a psychiatric unit per 100,000 inhabitants per year (Men)

Number of newly diagnosed patients with bipolar disorder who have had a contact with a psychiatric unit per year (Men)

Number of newly diagnosed patients with bipolar disorder who have had a contact with a psychiatric unit per 100,000 inhabitants per year (Women)

Number of newly diagnosed patients with bipolar disorder who have had a contact with a psychiatric unit per year (KWomen)

Number of newly diagnosed patients with bipolar disorder and abuse diagnosis who have had contact with a psychiatric unit per 100,000 inhabitants per year (Total) (ICD-10: F10-F19)

Number of newly diagnosed patients with bipolar disorder and abuse diagnosis who have had contact with a psychiatric unit per year (Total) (ICD-10: F10-F19)

Number of newly diagnosed patients with bipolar disorder and abuse diagnosis who have had contact with a psychiatric unit per 100,000 inhabitants per year (Men) (ICD-10: F10-F19)

Number of newly diagnosed patients with bipolar disorder and abuse diagnosis who have had contact with a psychiatric unit per year (Men) (ICD-10: F10-F19)

Number of newly diagnosed patients with bipolar disorder and abuse diagnosis who have had contact with a psychiatric unit per 100,000 inhabitants per year (Women) (ICD-10: F10-F19)

Number of newly diagnosed patients with bipolar disorder and abuse diagnosis who have had contact with a psychiatric unit per year (Women) (ICD-10: F10-F19) 
Number of patients diagnosed with bipolar disorder who have had contact with a psychiatric unit per. 100,000 inhabitants per year (Total)

Number of patients diagnosed with bipolar disorder who have had contact with a psychiatric unit per. 100,000 inhabitants per year (Total) (age group: 18-24)

Number of patients diagnosed with bipolar disorder who have had contact with a psychiatric unit per. 100,000 inhabitants per year (Total) (age group: 25-44)

Number of patients diagnosed with bipolar disorder who have had contact with a psychiatric unit per. 100,000 inhabitants per year (Total) (age group: 45-64)

Number of patients diagnosed with bipolar disorder who have had contact with a psychiatric unit per. 100,000 inhabitants per year (Total) (age group: 65-84)

Number of patients diagnosed with bipolar disorder who have had contact with a psychiatric unit per. 100,000 inhabitants per year (Total) (age group: $85+$ )

Number of patients diagnosed with bipolar disorder who have had contact with a psychiatric unit per. 100,000 inhabitants per year (Men)

Number of patients diagnosed with bipolar disorder who have had contact with a psychiatric unit per. 100,000 inhabitants per year (Men) (age group: 18-24)

Number of patients diagnosed with bipolar disorder who have had contact with a psychiatric unit per. 100,000 inhabitants per year (Men) (age group: 25-44)

Number of patients diagnosed with bipolar disorder who have had contact with a psychiatric unit per. 100,000 inhabitants per year (Men) (age group: 45-64)

Number of patients diagnosed with bipolar disorder who have had contact with a psychiatric unit per. 100,000 inhabitants per year (Men) (age group: 65-84)

Number of patients diagnosed with bipolar disorder who have had contact with a psychiatric unit per. 100,000 inhabitants per year (Men) (age group: 85+)

Number of patients diagnosed with bipolar disorder who have had contact with a psychiatric unit per. 100,000 inhabitants per year (Women)

Number of patients diagnosed with bipolar disorder who have had contact with a psychiatric unit per. 100,000 inhabitants per year (Women) (age group: 18-24)

Number of patients diagnosed with bipolar disorder who have had contact with a psychiatric unit per. 100,000 inhabitants per year (Women) (age group: 25-44)

Number of patients diagnosed with bipolar disorder who have had contact with a psychiatric unit per. 100,000 inhabitants per year (Women) (age group: 45-64)

Number of patients diagnosed with bipolar disorder who have had contact with a psychiatric unit per. 100,000 inhabitants per year (Women) (age group: 65-84)

Number of patients diagnosed with bipolar disorder who have had contact with a psychiatric unit per. 100,000 inhabitants per year (Women) (age group: $85+$ )

Number of patients diagnosed with bipolar disorder and abuse diagnosis who have had contact with a psychiatric unit per. 100,000 inhabitants per year (Total) (ICD-10: F10-F19)

Number of patients diagnosed with bipolar disorder and abuse diagnosis who have had contact with a psychiatric unit per. 100,000 inhabitants per year (Total) (ICD-10: F10-F19) (age group: 18-24)

Number of patients diagnosed with bipolar disorder and abuse diagnosis who have had contact with a psychiatric unit per. 100,000 inhabitants per year (Total) (ICD-10: F10-F19) (age group: 25-44)

Number of patients diagnosed with bipolar disorder and abuse diagnosis who have had contact with a psychiatric unit per. 100,000 inhabitants per year (Total) (ICD-10: F10-F19) (age group: 45-64)

Number of patients diagnosed with bipolar disorder and abuse diagnosis who have had contact with a psychiatric unit per. 100,000 inhabitants per year (Total) (ICD-10: F10-F19) (age group: 65-84)

Number of patients diagnosed with bipolar disorder and abuse diagnosis who have had contact with a psychiatric unit per. 100,000 inhabitants per year (Total) (ICD-10: F10-F19) (age group: 85+)

Number of patients diagnosed with bipolar disorder and abuse diagnosis who have had contact with a psychiatric unit per. 100,000 inhabitants per year (Men) (ICD-10: F10-F19)

Number of patients diagnosed with bipolar disorder and abuse diagnosis who have had contact with a psychiatric unit per. 100,000 inhabitants per year (Men) (ICD-10: F10-F19) (age group: 18-24)

Number of patients diagnosed with bipolar disorder and abuse diagnosis who have had contact with a psychiatric unit per. 100,000 inhabitants per year (Men) (ICD-10: F10-F19) (age group: 25-44)

Number of patients diagnosed with bipolar disorder and abuse diagnosis who have had contact with a psychiatric unit per. 100,000 inhabitants per year (Men) (ICD-10: F10-F19) (age group: 45-64)

Number of patients diagnosed with bipolar disorder and abuse diagnosis who have had contact with a psychiatric unit per. 100,000 inhabitants per year (Men) (ICD-10: F10-F19) (age group: 65-84)

Number of patients diagnosed with bipolar disorder and abuse diagnosis who have had contact with a psychiatric unit per. 100,000 inhabitants per year (Men) (ICD-10: F10-F19) (age group: 85+)

Number of patients diagnosed with bipolar disorder and abuse diagnosis who have had contact with a psychiatric unit per. 100,000 inhabitants per year (Women) (ICD-10: F10-F19)

Number of patients diagnosed with bipolar disorder and abuse diagnosis who have had contact with a psychiatric unit per. 100,000 inhabitants per year (Women) (ICD-10: F10-F19) (age group: 18-24)

Number of patients diagnosed with bipolar disorder and abuse diagnosis who have had contact with a psychiatric unit per. 100,000 inhabitants per year (Women) (ICD-10: F10-F19) (age group: 25-44)

Number of patients diagnosed with bipolar disorder and abuse diagnosis who have had contact with a psychiatric unit per. 100,000 inhabitants per year (Women) (ICD-10: F10-F19) (age group: 45-64)

Number of patients diagnosed with bipolar disorder and abuse diagnosis who have had contact with a psychiatric unit per. 100,000 inhabitants per year (Women) (ICD-10: F10-F19) (age group: 65-84)

Number of patients diagnosed with bipolar disorder and abuse diagnosis who have had contact with a psychiatric unit per. 100,000 inhabitants per year (Women) (ICD-10: F10-F19) (age group: 85+) 
Is there a National Quality Register for this?

Existing National clinical practice guidelines for bipolar disorder?

Adherence to lithium treatment of bipolar disorder (persons with a withdrawal of lithium prescription in the recipe for 1-4 months and 9-12 months during a period in relation to all persons with lithium treatment during the same period)

Number of deaths per 10000 residents whit bipolar disorder who at some time in the past five years been treated for bipolar disorder (20-59 years)

Readmission after 14 to 28 days following in-patient treatment for bipolar disorder

Readmission after 3 to 6 months following in-patient treatment for bipolar disorder

Unplanned bipolar disorder (any hospital) re-admission rate

Unplanned bipolar disorder (same hospital) re-admission rate

\section{Depression}

Number of patients diagnosed with depression who have had contact with a psychiatric unit per 100,000 inhabitants per year (Total)

Number of patients diagnosed with depression who have had contact with a psychiatric unit per 100,000 inhabitants per year (Total) (age group: 18-24)

Number of patients diagnosed with depression who have had contact with a psychiatric unit per 100,000 inhabitants per year (Total) (age group: 25-44)

Number of patients diagnosed with depression who have had contact with a psychiatric unit per 100,000 inhabitants per year (Total) (age group: 45-64)

Number of patients diagnosed with depression who have had contact with a psychiatric unit per 100,000 inhabitants per year (Total) (age group: 65-84)

Number of patients diagnosed with depression who have had contact with a psychiatric unit per 100,000 inhabitants per year (Total) (age group: 85+)

Number of patients diagnosed with depression who have had contact with a psychiatric unit per 100,000 inhabitants per year (Men)

Number of patients diagnosed with depression who have had contact with a psychiatric unit per 100,000 inhabitants per year (Men) (age group: 18-24)

Number of patients diagnosed with depression who have had contact with a psychiatric unit per 100,000 inhabitants per year (Men) (age group: 25-44)

Number of patients diagnosed with depression who have had contact with a psychiatric unit per 100,000 inhabitants per year (Men) (age group: 45-64)

Number of patients diagnosed with depression who have had contact with a psychiatric unit per 100,000 inhabitants per year (Men) (age group: 65-84)

Number of patients diagnosed with depression who have had contact with a psychiatric unit per 100,000 inhabitants per year (Men) (age group: 85+)

Number of patients diagnosed with depression who have had contact with a psychiatric unit per 100,000 inhabitants per year (Women)

Number of patients diagnosed with depression who have had contact with a psychiatric unit per 100,000 inhabitants per year (Women) (age group: 18-24)

Number of patients diagnosed with depression who have had contact with a psychiatric unit per 100,000 inhabitants per year (Women) (age group: 25-44)

Number of patients diagnosed with depression who have had contact with a psychiatric unit per 100,000 inhabitants per year (Women) (age group: 45-64)

Number of patients diagnosed with depression who have had contact with a psychiatric unit per 100,000 inhabitants per year (Women) (age group: 65-84)

Number of patients diagnosed with depression who have had contact with a psychiatric unit per 100,000 inhabitants per year (Women) (age group: 85+)

Number of patients diagnosed with depression and abuse diagnosis who have had contact with a psychiatric unit per 100,000 inhabitants per year (Total) (ICD-10: F10-F19)

Number of patients diagnosed with depression and abuse diagnosis who have had contact with a psychiatric unit per 100,000 inhabitants per year (Total) (ICD-10: F10-F19) (age group: 18-24)

Number of patients diagnosed with depression and abuse diagnosis who have had contact with a psychiatric unit per 100,000 inhabitants per year (Total) (ICD-10: F10-F19) (age group: 25-44)

Number of patients diagnosed with depression and abuse diagnosis who have had contact with a psychiatric unit per 100,000 inhabitants per year (Total) (ICD-10: F10-F19) (age group: 45-64)

Number of patients diagnosed with depression and abuse diagnosis who have had contact with a psychiatric unit per 100,000 inhabitants per year (Total) (ICD-10: F10-F19) (age group: 65-84)

Number of patients diagnosed with depression and abuse diagnosis who have had contact with a psychiatric unit per 100,000 inhabitants per year (Total) (ICD-10: F10-F19) (age group: $85+$ )

Number of patients diagnosed with depression and abuse diagnosis who have had contact with a psychiatric unit per 100,000 inhabitants per year (Men) (ICD-10: F10-F19)

Number of patients diagnosed with depression and abuse diagnosis who have had contact with a psychiatric unit per 100,000 inhabitants per year (Men) (ICD-10: F10-F19) (age group: 18-24)

Number of patients diagnosed with depression and abuse diagnosis who have had contact with a psychiatric unit per 100,000 inhabitants per year (Men) (ICD-10: F10-F19) (age group: 25-44)

Number of patients diagnosed with depression and abuse diagnosis who have had contact with a psychiatric unit per 100,000 inhabitants per year (Men) (ICD-10: F10-F19) (age group: 45-64)

Number of patients diagnosed with depression and abuse diagnosis who have had contact with a psychiatric unit per 100,000 inhabitants per year (Men) (ICD-10: F10-F19) (age group: 65-84) 
Number of patients diagnosed with depression and abuse diagnosis who have had contact with a psychiatric unit per 100,000 inhabitants per year (Men) (ICD-10: F10-F19) (age group: 85+)

Number of patients diagnosed with depression and abuse diagnosis who have had contact with a psychiatric unit per 100,000 inhabitants per year (Women) (ICD-10: F10-F19)

Number of patients diagnosed with depression and abuse diagnosis who have had contact with a psychiatric unit per 100,000 inhabitants per year (Women) (ICD-10: F10-F19) (age group: 18-24)

Number of patients diagnosed with depression and abuse diagnosis who have had contact with a psychiatric unit per 100,000 inhabitants per year (Women) (ICD-10: F10-F19) (age group: 25-44)

Number of patients diagnosed with depression and abuse diagnosis who have had contact with a psychiatric unit per 100,000 inhabitants per year (Women) (ICD-10: F10-F19) (age group: 45-64)

Number of patients diagnosed with depression and abuse diagnosis who have had contact with a psychiatric unit per 100,000 inhabitants per year (Women) (ICD-10: F10-F19) (age group: 65-84)

Number of patients diagnosed with depression and abuse diagnosis who have had contact with a psychiatric unit per 100,000 inhabitants per year (Women) (ICD-10: F10-F19) (age group: 85+)

Proportion of hospitalized patients who die whithin 30 days after discharge from a psychiatric unit

Proportion of hospitalized patients who die whithin 60 days after discharge from a psychiatric unit Proportion of hospitalized patients who die whithin 90 days after discharge from a psychiatric unit Number of patients with depression who received treatment with electrovonvulsive therapy (ECT) relative to number of patients with depression in total (code BRXA1) (moderate to severe, severe)

Is there a National Quality Register for this?

Existing National clinical practice guidelines for depression?

Proportion of hospitalized patients who are assessed depression severity by Hamilton Depression Scale (HAMD17) within 7 days from date of admission on a psychiatric unit

Proportion of hospitalized patients who have been assessed depression severity at Hamilton Depresions Scale (HAM-D17) at discharge from a psychiatric unit

Proportion of hospitalized patients with depression as assessed by a specialist in psychiatry within 7 days after the date of admission to a psychiatric unit

Proportion of hospitalized patients where there has been initial somatic examination within 2 days from the date of admission

Proportion of hospitalized patients assessed for suicide risk at admission to a psychiatric unit

Proportion of hospitalized patients for which need for social support has been assessed latest at the discharge from a psychiatric unit

Proportion of hospitalized patients where relatives are offered a contact with psychiatry, latest at discharge from a psychiatric unit

Proportion of hospitalized patients where a planned follow-up is agreed at the discharge from a psychiatric unit Proportion of outpatients assessed by a specialist in psychiatry within 30 days after first outpatient visit Proportion of outpatients who were examined for suicide risk at first outpatient visit

Proportion of outpatients for which need for social support has been assessed latest at the end of the outpatient pathway

Proportion of outpatients where relatives are offered a contact for inclusion within 90 days after first outpatient contact

Proportion of outpatients receiving assessed depression severity by validated assesment scale for depression symtom within 30 days after first outpatient visit

Proportion of outpatients receiving assessed depression severity by validated scale at the end of a outpatient pathway

Readmission to a psychiatric unit for depression disorder (14 to 28 days)

Readmission to a psychiatric unit for depression disorder ( 3 to 6 months)

Number of deaths per 10000 whit depression who at some time in the past five years been treated for depression (20-59 years) (are related to all deceased)

Number of deaths per 10000 whit depression who at some time in the past five years been treated for depression (20-59 years) (are related to all deceased)

Number of deaths per 10000 residents (20-59 years)

Schizophrenia (Children and Adolescents)

Number of newly diagnosed hospitalized patients with schizoph renia who have had contact with a psychiatric unit per 100,000 inhabitants per year (Total)

Number of newly diagnosed outpatients with schizophrenia who have had contact with a psychiatric unit per 100,000 inhabitants per year (Total)

Number of newly diagnosed patients with schizophrenia who have had contact with a psychiatric unit per 100,000 inhabitants per year (Total)

Number of newly diagnosed patients with schizophrenia who have had contact with a psychiatric unit per year (Total)

Number of patients diagnosed with schizophrenia who have had contact with a psychiatric unit per 100,000 inhabitants per year (Total)

Is there a National Quality Register for this?

Existing National clinical practice guidelines for schizophrenia?

Unplanned schizophrenia (any hospital) re-admission rate

Unplanned schizophrenia (same hospital) re-admission rate

Proportion of incident (diagnosed within 12 months of contact) patients examined for psychopathology by a medical specialist

Proportion of incident (diagnosed within 12 months of contact) patients examined for psychopathology by a specialist where the assessment is done using a diagnostic instrument (SCAN, OPCRIT, SCID) 
Proportion of incident (diagnosed within 12 months of contact) patients for whom cognitive function was examined by a psychologist

Proportion of incident (diagnosed within 12 months of contact) patients for which need for social support has been assessed by a medical social worker, councellor, welfare officer, not medical social worker

Proportion of incident (diagnosed within 12 months of contact) patients examined for duration of untreated psychosis and who is treatet within 6 months after the first symptoms

Proportion of outpatients with schizophrenia in contact with a specific member of the therapist team and/or

for whom a psychotherapeutic course of treatment is implemented

Proportion of patients with schizophrenia where relatives accept the offer of contact with the treatment

system

Proportion of children and adolescents with incident schizophrenia receiving psychoeducation via a manualized course within 2 years of discharge

Proportion of hospitalized patients assessed for suicide risk (documented in patient record) at discharge

Proportion of patents with schizophrenia on anti-psychotic medication

Proportion of outpatients with schizophrenia who receive more than one antipsychotic drug

Proportion of outpatients with schizophtrenia receiving benzodiazepines with the exception of benxodiazepines

(zolpidem, zopiclon, zaleplon)

Proportion of patients with a Global Assessment of Function (GAF) score of 30 days or less at discharge receiv

ing social support measures in their home

Proportion of patients discharged to an outpatient program

Proportion of patients discharged to an outpatient program for whom an outpatients' visit is registered within

18 months of discharge

Proportion of patients who have neurological side effects

Proportion of patients who have sleeping and sedation side effects

Proportion of patients who gain weight as a side effect

Proportion of patients who have sexual side effects

Proportion of patients who have an increased body mass index (BMI)

Proportion of patients who have an increased waistline measure

Proportion of patients who have an increased blood glucose level

Proportion of patients who have an increased level of blood lipids

Proportion of patients who have an increased blood pressure

\section{Generic indicators}

Proportion of psychiatric patients who are treated in the a psychiatric unit per. 100,000 inhabitants (Total) Proportion of psychiatric patients who are treated in the a psychiatric unit per. 100,000 inhabitants (Total) (age group: 0-17)

Proportion of psychiatric patients who are treated in the a psychiatric unit per. 100,000 inhabitants (Total) (age group: 18-24)

Proportion of psychiatric patients who are treated in the a psychiatric unit per. 100,000 inhabitants (Total) (age group: 25-44)

Proportion of psychiatric patients who are treated in the a psychiatric unit per. 100,000 inhabitants (Total) (age group: 45-64)

Proportion of psychiatric patients who are treated in the a psychiatric unit per. 100,000 inhabitants (Total) (age group: 65-84)

Proportion of psychiatric patients who are treated in the a psychiatric unit per. 100,000 inhabitants (Total) (age group: $85+$ )

Proportion of psychiatric patients who are treated in the a psychiatric unit per. 100,000 inhabitants (Men) Proportion of psychiatric patients who are treated in the a psychiatric unit per. 100,000 inhabitants (Men) (age group: 0-17)

Proportion of psychiatric patients who are treated in the a psychiatric unit per. 100,000 inhabitants (Men) (age group: 18-24)

Proportion of psychiatric patients who are treated in the a psychiatric unit per. 100,000 inhabitants (Men) (age group: $25-44)$

Proportion of psychiatric patients who are treated in the a psychiatric unit per. 100,000 inhabitants (Men) (age group: 45-64)

Proportion of psychiatric patients who are treated in the a psychiatric unit per. 100,000 inhabitants (Men) (age group: 65-84)

Proportion of psychiatric patients who are treated in the a psychiatric unit per. 100,000 inhabitants (Men) (age group: $85+)$

Proportion of psychiatric patients who are treated in the a psychiatric unit per. 100,000 inhabitants (Women) Proportion of psychiatric patients who are treated in the a psychiatric unit per. 100,000 inhabitants (Women) (age group: 0-17)

Proportion of psychiatric patients who are treated in the a psychiatric unit per. 100,000 inhabitants (Women) (age group: 18-24)

Proportion of psychiatric patients who are treated in the a psychiatric unit per. 100,000 inhabitants (Women) (age group: 25-44)

Proportion of psychiatric patients who are treated in the a psychiatric unit per. 100,000 inhabitants (Women) (age group: 45-64)

Proportion of psychiatric patients who are treated in the a psychiatric unit per. 100,000 inhabitants (Women)

(age group: 65-84) 
Proportion of psychiatric patients who are treated in the a psychiatric unit per. 100,000 inhabitants (Women) (age group: $85+$ )

The number of relevant professionals per 100,000 inhabitants (Psychiatrists)

The number of relevant professionals per 100,000 inhabitants (Psychatric nurses)

The number of relevant professionals per 100,000 inhabitants (Psychologists)

The number of relevant professionals per 100,000 inhabitants (Child psychiatrists)

Number of suicides in admissions to psychiatric hospital or department per 100,000 inhabitants

Deaths from suicide per 100.000 inhabitants (psychiatric patients) (Total)

Deaths from suicide per 100.000 inhabitants (psychiatric patients) (Total) (aldersgruppe: 18-24)

Deaths from suicide per 100.000 inhabitants (psychiatric patients) (Total) (aldersgruppe: 25-44)

Deaths from suicide per 100.000 inhabitants (psychiatric patients) (Total) (aldersgruppe: 45-64)

Deaths from suicide per 100.000 inhabitants (psychiatric patients) (Total) (aldersgruppe: 65-84)

Deaths from suicide per 100.000 inhabitants (psychiatric patients) (Total) (aldersgruppe: $85+$ )

Deaths from suicide per 100.000 inhabitants (psychiatric patients) (Men)

Deaths from suicide per 100.000 inhabitants (psychiatric patients) (Men) (aldersgruppe: 18-24)

Deaths from suicide per 100.000 inhabitants (psychiatric patients) (Men) (aldersgruppe: 25-44)

Deaths from suicide per 100.000 inhabitants (psychiatric patients) (Men) (aldersgruppe: 45-64)

Deaths from suicide per 100.000 inhabitants (psychiatric patients) (Men) (aldersgruppe: 65-84)

Deaths from suicide per 100.000 inhabitants (psychiatric patients) (Men) (aldersgruppe: $85+$ )

Deaths from suicide per 100.000 inhabitants (psychiatric patients) (Women)

Deaths from suicide per 100.000 inhabitants (psychiatric patients) (Women) (aldersgruppe: 18-24)

Deaths from suicide per 100.000 inhabitants (psychiatric patients) (Women) (aldersgruppe: 25-44)

Deaths from suicide per 100.000 inhabitants (psychiatric patients) (Women) (aldersgruppe: 45-64)

Deaths from suicide per 100.000 inhabitants (psychiatric patients) (Women) (aldersgruppe: 65-84)

Deaths from suicide per 100.000 inhabitants (psychiatric patients) (Women) (aldersgruppe: $85+$ )

Costs for specialized psychiatric units per. 100,000 inhabitants

Number of psychiatric beds, per 100000 inhabitants

Discharges (completed inpatient episodes) from psychiatric units, per 1000 inhabitants

Beds days per 1000 inhabitants in psychiatric units

Averige length of stay in psychiatric units

Number og mental health patients staying in hospitals continuously for more than 1 year, per 100000 inhabit-

ants

Hospital treatment in psychiatric units (Total)

Hospital treatment in psychiatric units (Total) (aldersgruppe: 0-14)

Hospital treatment in psychiatric units (Total) (aldersgruppe: 15-29)

Hospital treatment in psychiatric units (Total) (aldersgruppe: 30-44)

Hospital treatment in psychiatric units (Total) (aldersgruppe: 45-64)

Hospital treatment in psychiatric units (Total) (aldersgruppe: 65-79)

Hospital treatment in psychiatric units (Total) (aldersgruppe: $80+$ )

Hospital treatment in psychiatric units (Men)

Hospital treatment in psychiatric units (Men) (aldersgruppe: 0-14)

Hospital treatment in psychiatric units (Men) (aldersgruppe: 15-29)

Hospital treatment in psychiatric units (Men) (aldersgruppe: $30-44$ )

Hospital treatment in psychiatric units (Men) (aldersgruppe: 45-64) Hospital treatment in psychiatric units (Men) (aldersgruppe: 65-79)

Hospital treatment in psychiatric units (Men) (aldersgruppe: 80+)

Hospital treatment in psychiatric units (Women)

Hospital treatment in psychiatric units (Women) (aldersgruppe: 0-14)

Hospital treatment in psychiatric units (Women) (aldersgruppe: 15-29)

Hospital treatment in psychiatric units (Women) (aldersgruppe: 30-44)

Hospital treatment in psychiatric units (Women) (aldersgruppe: 45-64)

Hospital treatment in psychiatric units (Women) (aldersgruppe: 65-79)

Hospital treatment in psychiatric units (Women) (aldersgruppe: $80+$ )

Treated patients per 1000 inhabitants in psychiatric units (Total)

Treated patients per 1000 inhabitants in psychiatric units (Total) (Diagnostic group (ICD-10): F10-19) Treated patients per 1000 inhabitants in psychiatric units (Total) (Diagnostic group (ICD-10): F20-25) Treated patients per 1000 inhabitants in psychiatric units (Total) (Diagnostic group (ICD-10): F28-29) Treated patients per 1000 inhabitants in psychiatric units (Total) (Diagnostic group (ICD-10): F30-39) Treated patients per 1000 inhabitants in psychiatric units (Men) Treated patients per 1000 inhabitants in psychiatric units (Men) (Diagnostic group (ICD-10): F10-19) Treated patients per 1000 inhabitants in psychiatric units (Men) (Diagnostic group (ICD-10): F20-25) Treated patients per 1000 inhabitants in psychiatric units (Men) (Diagnostic group (ICD-10): F28-29) Treated patients per 1000 inhabitants in psychiatric units (Men) (Diagnostic group (ICD-10): F30-39) Treated patients per 1000 inhabitants in psychiatric units (Women)

Treated patients per 1000 inhabitants in psychiatric units (Women) (Diagnostic group (ICD-10): F10-19) Treated patients per 1000 inhabitants in psychiatric units (Women) (Diagnostic group (ICD-10): F20-25) Treated patients per 1000 inhabitants in psychiatric units (Women) (Diagnostic group (ICD-10): F28-29) Treated patients per 1000 inhabitants in psychiatric units (Women) (Diagnostic group (ICD-10): F30-39) 


\section{Generiske procesindikatorer for børn og unge til og med 17 år}

Proportion of patients who are diagnostic assessed in relation to clinical psychiatric dissorders Proportion of patients who are diagnostic assessed in relation to specific developmental disorders Proportion of patients who are diagnostic assessed in relation to current difficult psychosocial conditions Proportion of patients who are diagnostic assessed in relation to global assessment of psychosocial level of functioning (CGAS)

Proportion of patients who have waited more than 90 days visiting child- and adolescent psychiatry

Proportion of patients waiting less than 60 days (waiting time from referral to the first visit or the start of assessment)

Proportion of patients waiting less than 60 days (waiting time from referral to start of assessment)

Proportion of treatment with low compliance at the end of treatment or after 6 months

Waiting times no longer than 30 days for appointments at child and adolescent psychiatric clinics(proportion that had an appointment within 30 days)

Proportion of treatment with improved psychosocial functioning at the end of treatment or after 6 months 


\section{Nordisk ministerråd}

Ved Stranden 18

DK-1061 København K

www.norden.org

\section{Kvalitetsmåling i psykiatrien i de nordiske lande}

Nordisk Ministerråd iværksatte i 2007 projektet: Nordisk kvalitetsmåling i sundhedsvæsenet, der havde til formål i projektperioden 2007-2011 at udvikle og beskrive fællesnordiske kvalitetsindikatorer.

Projektgruppen skulle udarbejde forslag til indikatorer, som kunne danne grundlag for registrering og monitorering af kvaliteten af sundhedsvæsenets ydelser i de nordiske lande indenfor psykiatrien.

I rapporten præsenteres således alle kvalitetsindikatorer, der anvendes i de respektive nordiske lande indenfor i psykiatrien.

Rapporten viser, at det på nogle områder er muligt at tilvejebringe data, som muliggør sammenligning på tværs af de nordiske lande, mens der på andre områder kun i beskedent omfang findes tilgængelige data. Dette indebærer, at der fortsat på en række områder er behov for at udvikle fællesnordiske indikatorer. Rapporten illustrerer, at der er behov for en betydelig indsats med henblik på at sikre datakvaliteten. Dette indebærer, at en række af resultaterne næppe er retvisende, dels fordi data opgøres forskelligt i de nordiske lande, og dels fordi data på visse områder kun findes i begrænset omfang.

Rapporten dokumenterer, at der i de nordiske lande er et stort potentiale for måling og monitorering af kvaliteten af sundhedsvæsenets ydelser indenfor psykiatrien. Internationalt er dette område svagt belyst. I international sammenhæng er de nordiske lande således blandt de lande, der er nået længst med national kvalitetsmåling.

Der er således næppe tvivl om, at de nordiske lande kan bidrage i betydeligt omfang til inspiration og samarbejde om kvalitetsmåling på grundlag af kvalitetsindikatorer indenfor psykiatrien på internationalt niveau. 